\title{
Jurassic stratigraphy of East Greenland
}

\author{
Finn Surlyk ${ }^{\star 1}$, Peter Alsen ${ }^{2}$, Morten Bjerager ${ }^{2} \odot$, Gregers Dam² ${ }^{2}$, Michael Engkilde ${ }^{3}$, Carina Fabricius \\ Hansen ${ }^{4}$, Michael Larsen ${ }^{5}$, Nanna Noe-Nygaard ${ }^{1}$, Stefan Piasecki ${ }^{6}$, Jens Therkelsen ${ }^{7}$ \& Henrik \\ Vosgerau $^{2}$ (1)
}

${ }^{1}$ Department of Geosciences and Natural Resource Management, University of Copenhagen, Copenhagen, Denmark. ${ }^{2}$ Geological Survey of Denmark and Greenland, Copenhagen, Denmark. ${ }^{3} \mathrm{Kgs}$. Lyngby, Denmark, ${ }^{4}$ Birkerød, Denmark, ${ }^{5}$ NEOS Oil and Gas, Virum, Denmark. ${ }^{6} \mathrm{Globe}$ Institute, Section for GeoBiology, University of Copenhagen, Denmark. ${ }^{7} \mathrm{MOE}$ A/S, Vordingborg, Denmark

\begin{abstract}
The East Greenland Rift Basin comprises a series of Jurassic subbasins with different crustal configurations, and somewhat different tectonic histories and styles. The roughly N-S elongated basin is exposed in central and northern East Greenland over a length of more than $600 \mathrm{~km}$ and a width of up to $250 \mathrm{~km}$. The southernmost exposures are found in the largest subbasin in Jameson Land, while the northernmost exposures are on Store Koldewey and in Germania Land. The focus of the present revision is on the Jurassic, but the uppermost Triassic and lowermost Cretaceous successions are included as they are genetically related to the Jurassic succession. The whole succession forms an overall transgressive-regressive megacycle with the highest sea level and maximum transgression in the Kimmeridgian.

The latest Triassic - Early Jurassic was a time of tectonic quiescence in East Greenland. Lower Jurassic deposits are up to about $950 \mathrm{~m}$ thick and are restricted to Jameson Land and a small down-faulted outlier in southernmost Liverpool Land. The Lower Jurassic succession forms an overall stratigraphic layer-cake package that records a shift from Rhaetian-Sinemurian fluvio-lacustrine to Pliensbachian - early Bajocian mainly shallow marine sedimentation.

Onset of rifting in the late Bajocian resulted in complete reorganisation of basin configuration and drainage patterns, and the depositional basin expanded far towards the north. Post-lower Bajocian early-rift deposits are up to about 500-600 m thick and are exposed in Jameson Land, Liverpool Land, Milne Land, Traill $\varnothing$, Geographical Society $\varnothing$, Hold with Hope, Clavering $\varnothing$, Wollaston Forland, Kuhn $\varnothing$, Th. Thomsen Land, Hochstetter Forland, Store Koldewey and Germania Land. Upper Jurassic rift-climax strata reach thicknesses of several kilometres and are exposed in the same areas with the exception of Liverpool Land and Germania Land.

In the southern part of the basin, the upper Bajocian - Kimmeridgian succession consists of stepwise backstepping units starting with shallow marine sandstones and ending with relatively deep marine mudstones in some places with sandy gravity-flow deposits and injectites. In the Jameson Land and Milne Land Subbasins, the uppermost Jurassic - lowermost Cretaceous (Volgian-Ryazanian) succession consists of forestepping stacked shelf-margin sandstone bodies with associated slope and basinal mudstones and massflow sandstones. North of Jameson Land, block-faulting and tilting began in the late Bajocian and culminated in the middle Volgian with formation of
\end{abstract}

\author{
*Correspondence: finns@ign.ku.dk \\ Received: 26 Feb 2019 \\ Accepted: 20 Dec 2019 \\ Published: 9 Jul 2021
}

Keywords: East Greenland, stratigraphy, siliciclastic sediments, uppermost Triassic, Jurassic, lowermost Cretaceous

Edited by: Jon R. Ineson (GEUS, Denmark)

Reviewed by: Snorre Olaussen (The University Centre in Svalbard, Norway); Harald Brekke (Norwegian Petroleum Directorate, Norway)

Funding: See page 111

Competing interests: None declared

Additional files: None provided 
strongly tilted fault blocks, and the succession records continued stepwise deepening. In the Wollaston Forland - Kuhn $\varnothing$ area, the Volgian is represented by a thick wedge of deep-water conglomerates and pebbly sandstones passing basinwards into mudstones deposited in fault-attached slope aprons and coalescent submarine fans.

The lithostratigraphic scheme established mainly in the 1970s and early 1980s is here revised on the basis of work undertaken over subsequent years. The entire Jurassic succession, including the uppermost Triassic (Rhaetian) and lowermost Cretaceous (Ryazanian-Hauterivian), forms the Jameson Land Supergroup. The supergroup is subdivided into the Kap Stewart, Neill Klinter, Vardekløft, Hall Bredning, and Wollaston Forland Groups, which are subdivided into 25 formations and 48 members. Many of these are revised, and 3 new formations and 14 new members are introduced. 


\section{Introduction}

The Jurassic of East Greenland has a long exploration history and its stratigraphic nomenclature has undergone several phases of revision. Many new units have been defined since the naming of the first formations early in the 20th century. The first formal lithostratigraphic schemes covering the whole Jurassic succession, including the uppermost Triassic and lowermost Cretaceous, were established by Surlyk et al. (1973) for Jameson Land, Surlyk (1977a, 1978a) for the Wollaston Forland - Kuhn $\varnothing$ area, and Callomon \& Birkelund (1980) and Birkelund et al. (1984) for Milne Land (Figs 1-3).

These schemes have proved very robust over time, but sedimentological and sequence stratigraphical projects carried out in more recent years have led to improved knowledge and a better understanding of the succession. A new subdivision of the Pliensbachian lower Bajocian part of the succession by Dam \& Surlyk (1998) was the first step in the revision and refinement of the older, low-resolution Jurassic lithostratigraphy of Surlyk et al. (1973).

In the present paper, a complete lithostratigraphic scheme is established for the Jurassic of East Greenland (Fig. 3). Most of the older units have been revised mainly by elevating the ranks of members and formations following more detailed studies. The stratigraphic scheme presented here includes the uppermost Triassic and lowermost Cretaceous formations and members because they are genetically related to the Jurassic units and because they form the base and top units in Jurassic groups, respectively.

Lithostratigraphic boundaries are normally diachronous and formations are in general rarely genetic sedimentary bodies. Formations are thus normally not well suited as a basis for basin analysis and interpretation of the stratigraphic development. This is particularly the case in poorly exposed or subsurface successions. However, in the case of the extensively and excellently exposed Jurassic of East Greenland the lithostratigraphic units are in most cases close to genetic stratigraphic units. This is because the natural boundaries used in their definition commonly coincide with sequence stratigraphic key surfaces and not only with simple lithological changes. However, the key surfaces have a distinct lithological expression and can be traced laterally over large areas. Most of the formations of the older schemes have thus been genetic units from the outset and discrepancy between lithostratigraphy and general sequence stratigraphy is rather minor. It is important to emphasise, however, that although the formational boundaries are commonly sequence stratigraphic key surfaces, it is

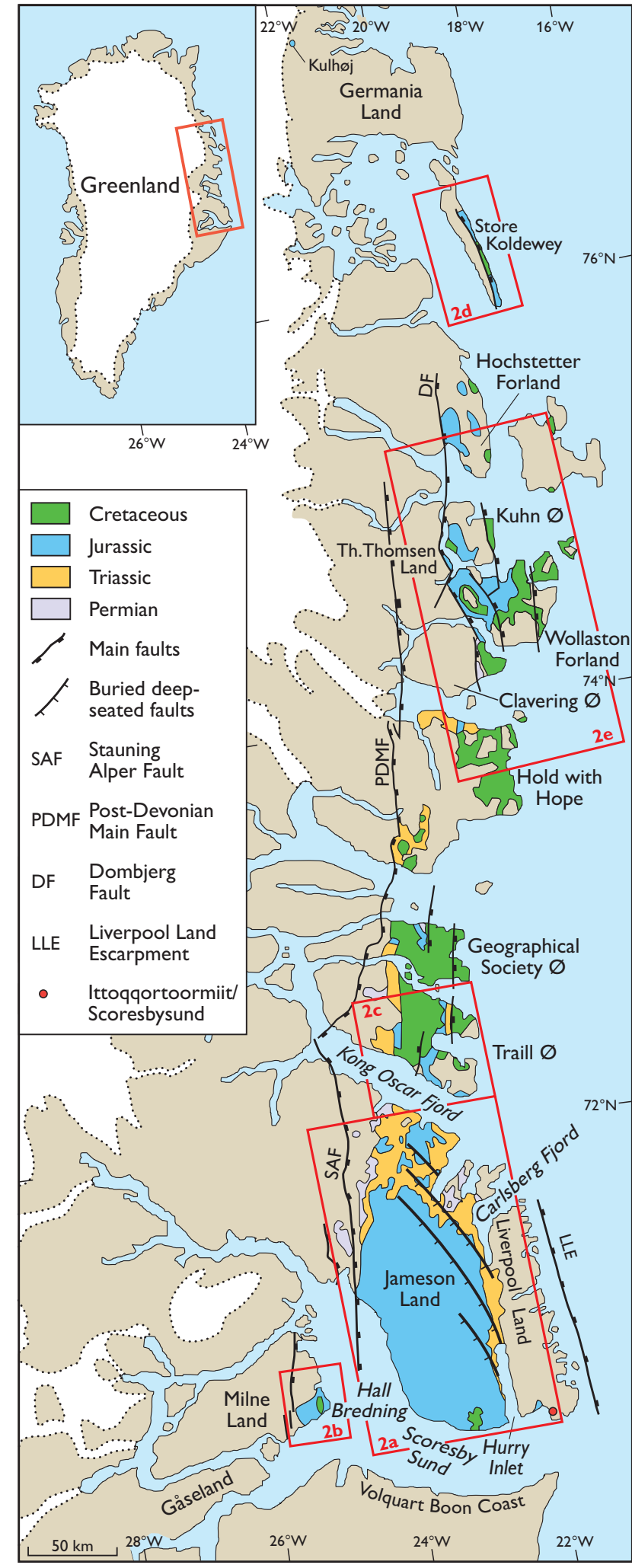

Fig. 1 Simplified geological map of the East Greenland Rift Basin showing the main faults active during the Jurassic, the main areas with outcrops of uppermost Triassic - lowermost Cretaceous formations, and the location of the detailed geological maps (Figs 2a-e). Modified from Surlyk (2003, fig. 2). 
their lithological expression rather than their interpretation that forms the basis for the definition.

The area of Greenland under focus here is, for simplicity, referred to broadly as East Greenland, following most earlier literature on this sedimentary basin complex (see Surlyk 2003 and references therein). It should be noted, however, that this geographical area is included in the more rigorously defined regions of central East Greenland and North-East Greenland as presented by Ghisler (1990). A short note on place names is also necessary to avoid confusion due to unclear definitions. Jameson Land is here understood as the peninsula between Scoresby Sund and Kong Oscar Fjord, bounded to the west by the north-south-trending valley of Schuchert Dal and to the east by the Klitdal valley, which separates Jameson Land and Liverpool Land (Figs 1, 2a). The name Scoresby Land has sometimes been used in the literature for what is here considered north-western Jameson Land, but Scoresby Land as originally defined covers a much larger area, including but extending beyond Jameson Land, and the name is thus not used in this account. 


\section{Geological setting}

The Mesozoic basin of East Greenland includes a series of Jurassic subbasins with different crustal configurations and somewhat different tectonic histories and styles. The largest of the onshore subbasins, the Jameson Land Subbasin, is located to the south in the area of present-day Jameson Land and probably continues towards the south below the basalts of the Volquart Boon Coast (Fig. 1; Larsen \& Marcussen 1992).

The Jameson Land Subbasin is delimited by roughly $\mathrm{N}-\mathrm{S}$ to NW-SE-trending border-faults. The northern boundary is interpreted as being defined by a system of deep-seated NW-SE-trending cross-faults down-throwing to the south (Surlyk 1978b; Dam et al. 1995). The faults probably originated as splays on the main $\mathrm{N}-\mathrm{S}$ faults bordering Devonian oblique-slip pull-apart basins (Fig. 1). Some major faults have been interpreted to have formed during Early Triassic rift phases, defining the overall NE-SW-trending Triassic basins (Guarnieri et al. 2017); Seidler et al. (2004) described two Early Triassic rift phases from NW Jameson Land controlled by NWSE-trending faults.

The latest Triassic - earliest Cretaceous basin evolution of East Greenland was reviewed by Surlyk (2003). The uppermost Triassic - Lower Jurassic is restricted to Jameson Land and southern Liverpool Land (Fig. 2a) and deposition was controlled by thermal contraction under relatively quiet tectonic conditions, accommodated by subsidence along the main basin-margin faults. Subsidence became markedly asymmetric in Middle-Late Jurassic times, being greatest towards the west or northwest, but Jameson Land retained the character of an extensive gently tilted platform undisturbed by significant faulting.

A major rift-phase began in the late Bajocian and culminated in the middle Volgian with the development of tilted fault blocks, especially in the Wollaston Forland
- Kuhn $\varnothing$ area (Surlyk 2003 and references therein; Surlyk \& Korstgård 2013). Jurassic deposition in this area took place in progressively deeper water and water depths in the Volgian may have reached almost $1 \mathrm{~km}$ along the axes of the hanging-wall basins (Surlyk 1978a, 1984).

The Jurassic succession shows marked onlap onto progressively older strata towards the north and on Milne Land also towards the west (Fig. 2b). This was associated with a younging of its base northwards from Jameson Land, where an almost complete Triassic-Jurassic succession is preserved. The Traill $\varnothing$ - Geographical Society $\varnothing$ (Fig 2c) area was onlapped in the late Bajocian and uppermost Triassic - lower Middle Jurassic sediments are missing. On Hold with Hope, farther towards the north (Fig 2e), lower Callovian strata rest directly on the Lower Triassic Wordie Creek Group (Vosgerau et al. 2004a). Reworked upper Bajocian / lower Bathonian ammonites occur in the basal Cretaceous pebble lag, however, suggesting that the area had been transgressed earlier in Middle Jurassic time, but the deposits were subsequently removed by pre-Callovian erosion. On Milne Land, Callovian and younger sediments onlap crystalline basement, forming a prominent rocky coast (Larsen et al. 2003). On Wollaston Forland, Bathonian deposits overlie Upper Permian carbonates to the south and crystalline basement to the north (Fig. 4). Farther north, on Kuhn $\varnothing$, Hochstetter Forland, Store Koldewey and Germania Land (Figs 1, 2d, 2e), upper Bathonian or lower Callovian marine or fluvial sandstones with coal rest on peneplaned crystalline basement. The progressive northwards Jurassic onlap has been interpreted to reflect late Early Jurassic domal uplift in northern East Greenland followed by erosion, domal collapse, onset of rifting and transgression in Middle Jurassic times (Surlyk 1977b, 1978b). 


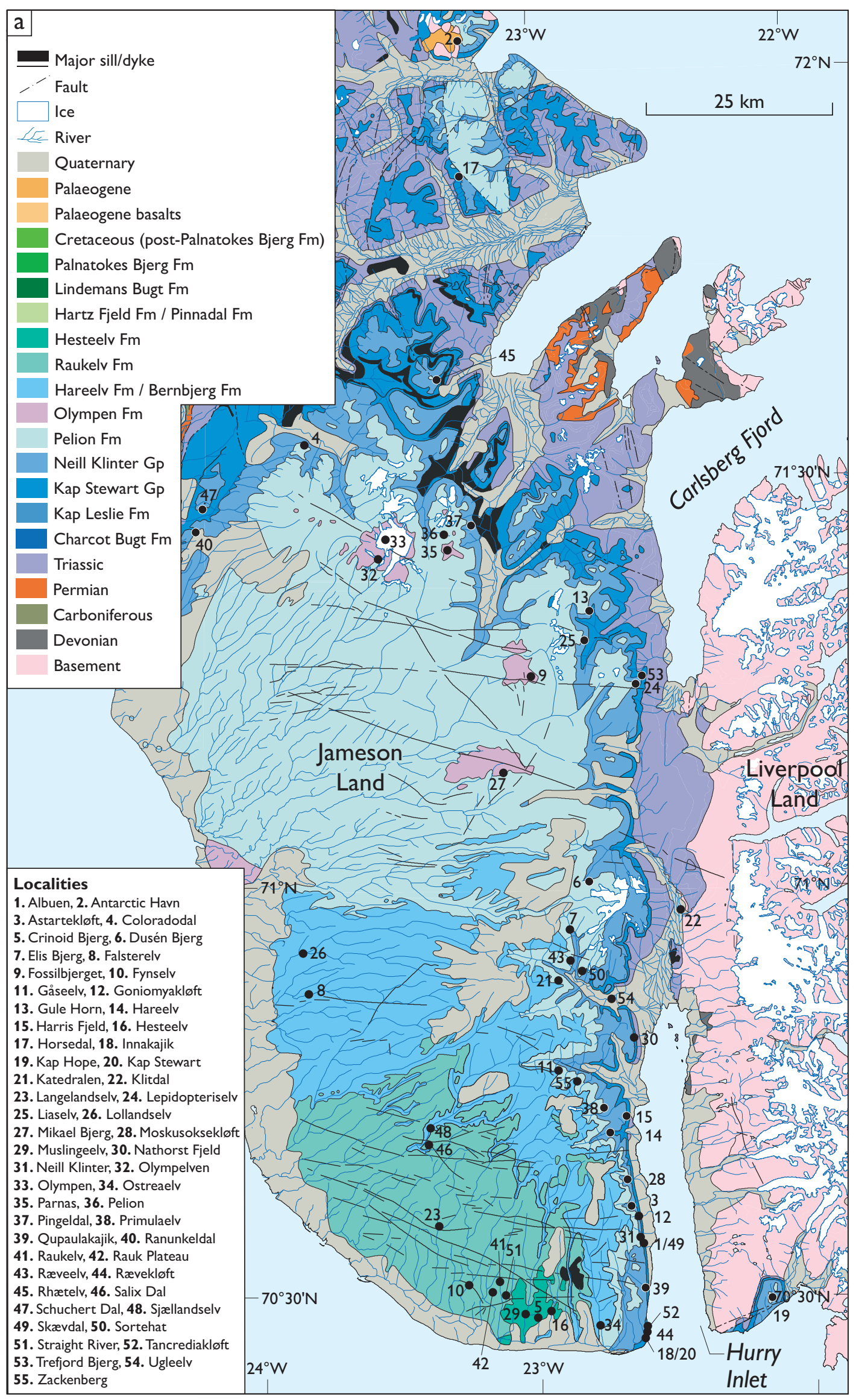

Fig. 2 Maps showing the position of place names and localities mentioned in the text. Based on the digital Greenland geological map at a scale of 1:500 000 (Kokfelt et al. 2013). (a): Geological and locality map of Jameson Land. The outcrop area indicated as the Pelion Formation on this map also includes the Fossilbjerget Formation. 

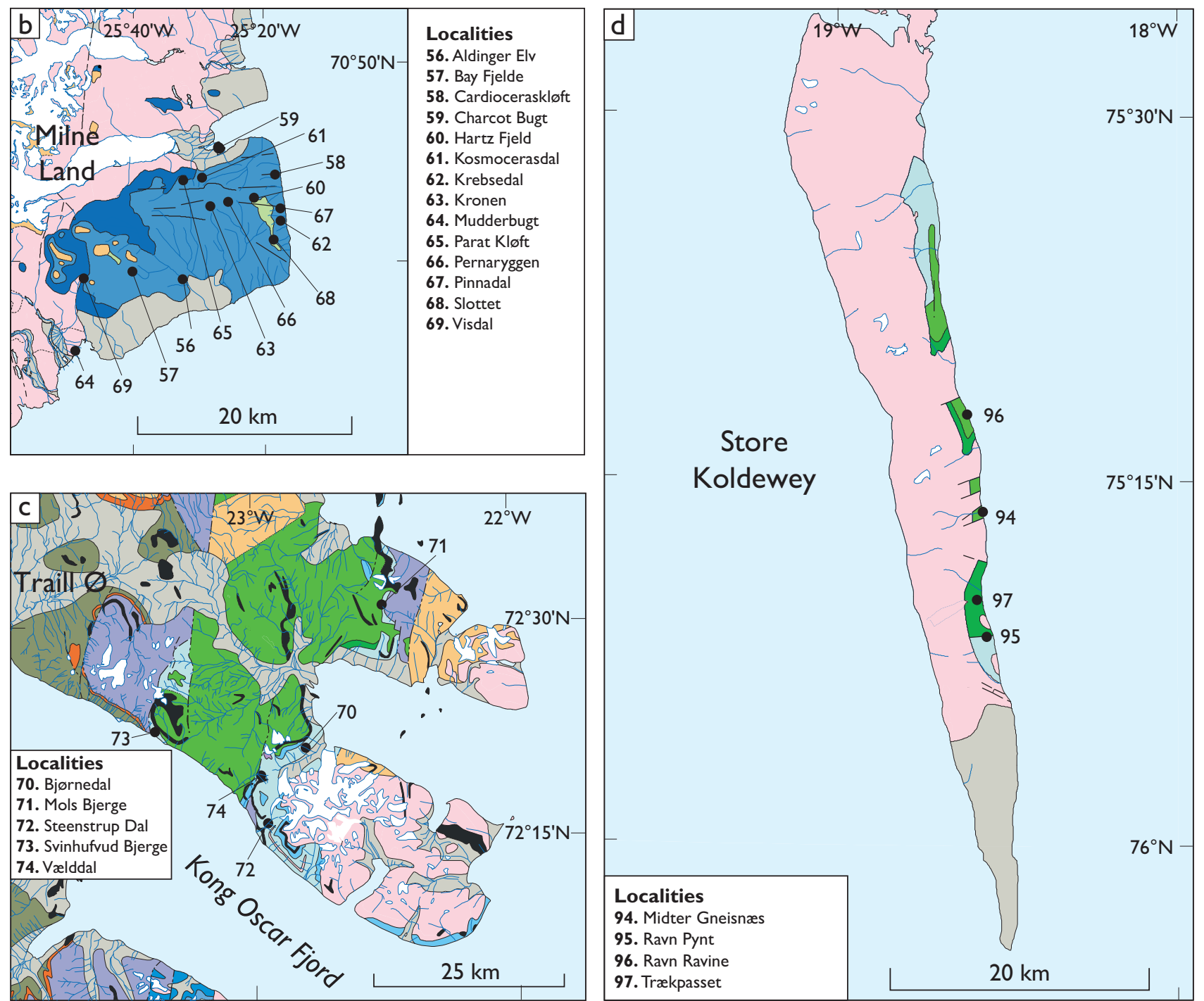

Fig. 2 (continued) Maps showing the position of place names and localities mentioned in the text. Based on the digital Greenland geological map at a scale of 1:500 000 (Kokfelt et al. 2013). (b) : Geological and locality map of south-east Milne Land. (c): Geological and locality map of eastern Traill $\varnothing$. The outcrop area indicated as the Pelion Formation on this map also includes the Bristol Elv, Fossilbjerget and Olympen Formations. (d): Geological and locality map of Store Koldewey. The outcrop area indicated as Pelion Formation on this map also includes the Bastians Dal, Muslingebjerg, Payer Dal and Bernbjerg Formations. 


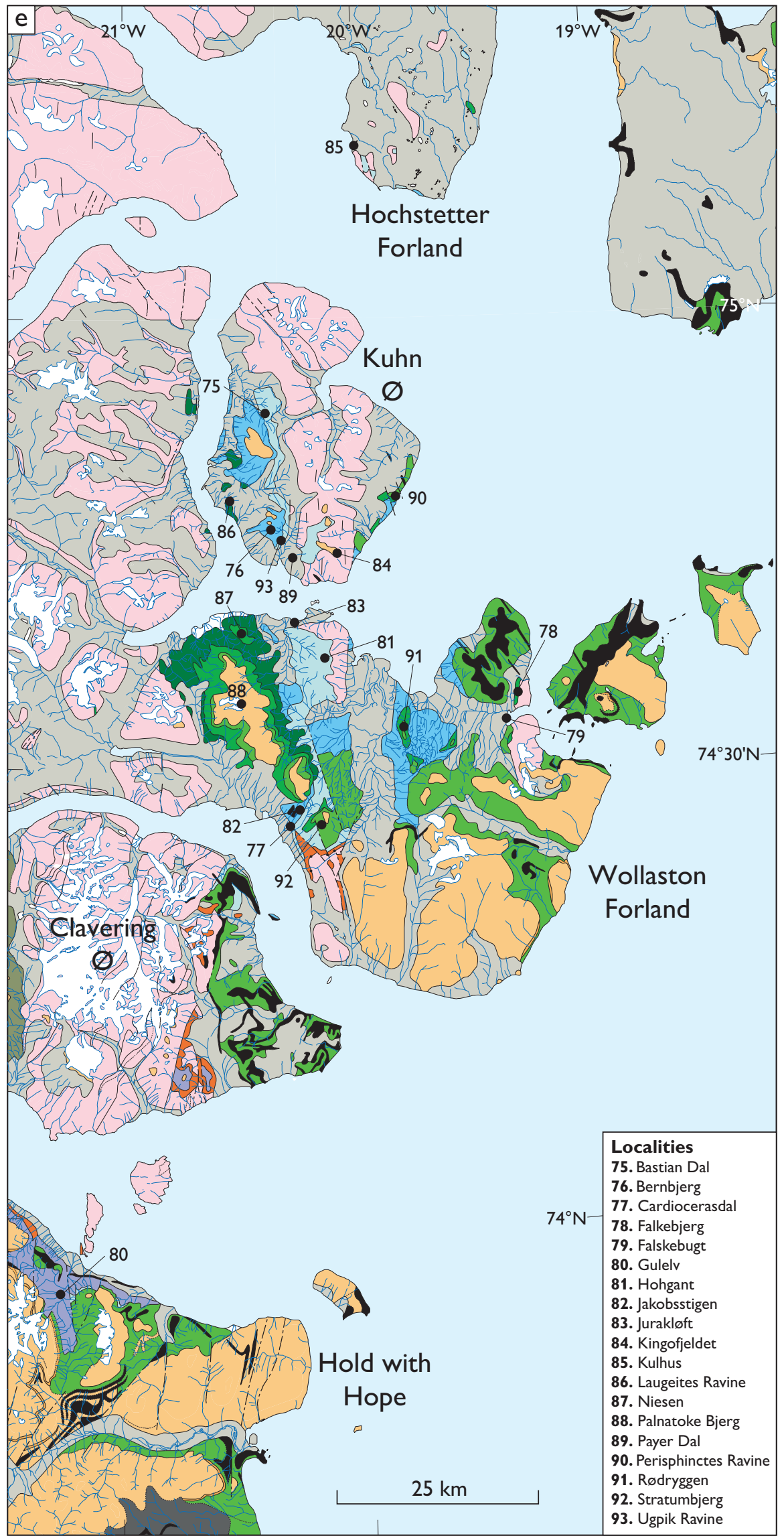

Fig. 2 (continued) Maps showing the position of place names and localities mentioned in the text. Based on the digital Greenland geological map at a scale of 1:500 000 (Kokfelt et al. 2013). (e): Geological and locality map of the Hold with Hope, Clavering $\varnothing$, Wollaston Forland, Kuhn $\varnothing$ and Hochstetter Forland area. The outcrop area indicated as the Pelion Formation on this map also includes the Bastians Dal, Muslingebjerg, Payer Dal and Jakobsstigen Formations.

Localities

. Bastian $\mathrm{Da}$

77. Cardiocerasda

78. Falkebjerg

79. Falskebug

82. Jakobsstigen

83. Jurakløft

87. Niesen

91. Rødryggen

93. Ugpik Ravine 


\section{Revised lithostratigraphy}

Early comprehensive studies and reviews of the Jurassic succession of East Greenland were given by Maync (1947), Donovan (1957), Haller (1971), Birkelund \& Perch-Nielsen (1976), and Surlyk (1990a). A synthesis of the Jurassic evolution of East Greenland was presented by Surlyk (2003). The lithostratigraphic scheme for the Jurassic of East Greenland was established by Surlyk et al. (1973), Surlyk (1977a, 1978a), Callomon \& Birkelund (1980) and Birkelund et al. (1984). The schemes of Surlyk (1977a, 1978a), Callomon \& Birkelund (1980), Birkelund et al. (1984) with minor revision, Dam \& Surlyk (1998) and Alsgaard et al. (2003) remain essentially unchanged but are included here for the sake of completeness. The other schemes are updated, following sedimentological, biostratigraphic and sequence stratigraphic studies of most of the formations during later years (Fig. 3).

The area under consideration lies in a remote part of Greenland (Fig. 1). There is only one permanent settlement (Ittoqqortoormiit/Scoresbysund; Fig. 1) and place names are few, especially in inland areas of large islands and peninsulas. The problem of lithostratigraphic name-giving is thus similar to that in offshore areas where sea birds, explorers, mythological figures or fishing-boat gear have been used in British and Norwegian offshore Jurassic stratigraphic terminology. In a few cases, names from Greek mythology are similarly proposed for new lithostratigraphic units because the nearby mountains Pelion, Parnas and Olympen with Greek mythological names have already been used for older units (Surlyk et al. 1973; Larsen \& Surlyk 2003). Key references are given under the individual units except for units where they are the same as for the formation or group.

The place names used in naming the lithostratigraphic units commonly have Danish suffixes for river, mountain etc. The most common are elv = river or mountain stream, bjerg = mountain, dal = valley, kløft $=$ ravine, $\operatorname{klint}(\mathrm{er})=\operatorname{cliff}(\mathrm{s})$. These names as used in the lithostratigraphic scheme should not be translated into English. The spelling of a name of an established stratigraphic unit must not be changed even if the spelling of the place name itself has subsequently been changed. Thus, the Palnatokes Bjerg Formation retains its original form (with the genitive ' $s$ ') despite the official geographical term now being Palnatoke Bjerg. Geographic coordinates are noted for all type sections. Many of these were measured at a time when available topographic maps were of poor quality and their precise locations could not be identified with certainty; other localities were positioned in the field on aerial, commonly oblique photographs. In all cases, the positions of the sections are indicated here as precisely as possible.
The sedimentary logs were measured by a number of different workers over a relatively long period of time and the style of presentation thus varies depending on the source, in some cases quite strongly. Some were measured by sedimentologists and grain sizes are carefully recorded and shown on the horizontal axis. Others were measured by non-sedimentologists and although sedimentary thicknesses and positions of samples were accurately recorded, little attention was paid to sedimentary facies and structures. Some sections were drawn to show topographic expression or weathering profile along the horizontal axis, rather than grain size, so that cemented beds stand out compared to loose, poorly cemented beds. We have attempted to present all logs in the same style, but in some cases the original log only depicted lithology and grain size by means of ornamentation rather than indicating grain-size variation along the horizontal axis of the log. These logs have been redrawn so that sandstones are labelled 'sand' and mudstones as 'clay' or 'silt' on the x-axis; more precise indications of grain size would have been based on guesswork.

A number of new units are defined here. They are described in more detail than those that were formally defined and adequately described in earlier literature (indicated under Key references). Some of the logs show only part of the unit in question because the base and/ or the top of the unit was not exposed or was inaccessible at the locality; this partial nature of the section is indicated by 'pars' on the logs.

The ammonite faunal horizons that provide the biostratigraphic framework for many of the units presented in this work refer to the ammonite successions described from Milne Land (Callomon \& Birkelund, 1980; Birkelund et al. 1984) and Jameson Land (Callomon 1993; Callomon et al. 2015). Note that the numbers of the faunal horizons are given the prefixes $\mathrm{M}$ - and J-, to clearly differentiate those defined from Milne Land from those recognised in Jameson Land (Callomon et al. 2015).

\section{Jameson Land Supergroup}

revised unit

History. The Jameson Land Group was erected by Surlyk et al. (1973). It is here elevated to the rank of supergroup and revised so as to embrace all of the Jurassic succession of East Greenland, including the genetically related uppermost Triassic and lowermost Cretaceous strata.

Type area. Jameson Land, central East Greenland. 


\begin{tabular}{|c|c|c|c|c|c|c|}
\hline \multicolumn{7}{|c|}{ Uppermost Triassic - lowermost Cretaceous of Jameson Land } \\
\hline \multicolumn{3}{|c|}{ Surlyk et al. (1973) } & \multicolumn{4}{|c|}{ This study } \\
\hline Group & Formation & Member & $\begin{array}{l}\text { Super- } \\
\text { group }\end{array}$ & Group & Formation & Member \\
\hline \multirow{31}{*}{$\begin{array}{l}\text { Jameson } \\
\text { Land }\end{array}$} & \multirow{2}{*}{ Hesteelv } & Muslingeelv & \multirow{31}{*}{$\begin{array}{l}\text { Jameson } \\
\text { Land } \boldsymbol{\nabla}\end{array}$} & \multirow{19}{*}{ Vardekløft $\nabla \triangle$} & \multirow{2}{*}{ Hesteelv } & Muslingeelv \\
\hline & & Crinoid Bjerg & & & & Crinoid Bjerg \\
\hline & \multirow{8}{*}{ Raukelv } & \multirow{6}{*}{ Fynselv } & & & \multirow{8}{*}{ Raukelv $\triangle$} & Rauk Plateau O \\
\hline & & & & & & Straight River $\bigcirc$ \\
\hline & & & & & & Kokkino O \\
\hline & & & & & & Fynselv $\triangle$ \\
\hline & & & & & & Prasino 0 \\
\hline & & & & & & Langelandselv $\bigcirc$ \\
\hline & & Salix Dal & & & & Salix Dal $\triangle$ \\
\hline & & Sjællandselv & & & & Sjællandselv $\triangle$ \\
\hline & Hareelv & & & & Hareelv & \\
\hline & \multirow{3}{*}{ Olympen } & & & & \multirow{3}{*}{ Olympen } & Zeus $\mathrm{O}$ \\
\hline & & & & & & Hades 0 \\
\hline & & & & & & Athene $O$ \\
\hline & \multirow{6}{*}{ Vardekløft } & Fossilbierget & & & \multirow{2}{*}{ Fossilbjerget $\boldsymbol{\nabla}$} & Goniomyakløft O \\
\hline & & \multirow{4}{*}{ Pelion } & & & & \\
\hline & & & & & \multirow{3}{*}{ Pelion $\boldsymbol{\nabla}$} & Parnas 0 \\
\hline & & & & & & \\
\hline & & & & & & Ugleelv $\bigcirc$ \\
\hline & & Sortehat & & \multirow{9}{*}{ Neill Klinter } & Sortehat & \\
\hline & \multirow{8}{*}{ Neill Klinter } & \multirow{5}{*}{ Ostreaelv } & & & \multirow{5}{*}{ Ostreaelv } & Trefjord Bjerg \\
\hline & & & & & & Skævdal \\
\hline & & & & & & $\begin{array}{c}\text { Nathorst Fjeld/Harris Fjeld } \\
\text { Lepidopteriselv }\end{array}$ \\
\hline & & & & & & Astartekløft \\
\hline & & & & & & Horsedal \\
\hline & & \multirow{2}{*}{ Gule Horn } & & & \multirow{2}{*}{ Gule Horn } & Albuen \\
\hline & & & & & & Elis Bjerg \\
\hline & & Rævekløft & & & Rævekløft & \\
\hline & \multirow{3}{*}{ Kap Stewart } & & & \multirow{3}{*}{ Kap Stewart $\boldsymbol{\nabla}$} & Rhætelv O & \\
\hline & & & & & Primulaelv $\bigcirc$ & \\
\hline & & & & & Innakajik O & \\
\hline
\end{tabular}

\begin{tabular}{|c|c|c|c|c|c|}
\hline \multicolumn{6}{|c|}{ Jurassic - lowermost Cretaceous of Milne Land } \\
\hline \multicolumn{2}{|c|}{$\begin{array}{c}\text { Callomon \& Birkelund (1980) and } \\
\text { Birkelund et al. (1984) }\end{array}$} & \multicolumn{4}{|c|}{ This study } \\
\hline Formation & Member & $\begin{array}{l}\text { Super- } \\
\text { group }\end{array}$ & Group & Formation & Member \\
\hline \multirow{3}{*}{ Hartz Fjeld } & Pinnadal & \multirow{13}{*}{$\begin{array}{l}\text { Jameson } \\
\text { Land } \boldsymbol{\nabla}\end{array}$} & \multirow{13}{*}{ Hall Bredning $O$} & Pinnadal $\boldsymbol{\nabla}$ & \\
\hline & \multirow{2}{*}{ Hennigryggen } & & & \multirow{2}{*}{ Hartz Fjeld } & Kronen $\mathrm{O}$ \\
\hline & & & & & Hennigryggen $\triangle$ \\
\hline \multirow{8}{*}{ Kap Leslie } & Astartedal & & & \multirow{8}{*}{ Kap Leslie } & Astartedal \\
\hline & Pernaryggen & & & & Pernaryggen \\
\hline & Krebsedal & & & & Krebsedal \\
\hline & Gråkløft & & & & Gråkløft \\
\hline & Cardioceraskløft & & & & Cardioceraskløft \\
\hline & Bays Elv & & & & Bays Elv \\
\hline & Aldinger Elv & & & & Aldinger Elv \\
\hline & Kosmocerasdal & & & & Kosmocerasdal \\
\hline \multirow{2}{*}{ Charcot Bugt } & Mudderbugt & & & \multirow{2}{*}{ Charcot Bugt } & Mudderbugt \\
\hline & Visdal & & & & Visdal \\
\hline
\end{tabular}

Fig. 3 Stratigraphical scheme showing older subdivisions together with the revised subdivision presented in this study, covering Jameson Land, Milne Land, Traill $\varnothing$, Geographical Society $\varnothing$, Hold with Hope, Clavering $\varnothing$, Wollaston Forland, Kuhn $\varnothing$, Hochstetter Forland, Store Koldewey and Germania Land. 


\begin{tabular}{|c|c|c|c|c|c|c|c|}
\hline \multicolumn{8}{|c|}{ Jurassic - lowermost Cretaceous of Store Koldewey and Germania Land } \\
\hline $\begin{array}{l}\text { Ravn (1911) } \\
\text { Koch (1929) }\end{array}$ & Surlyk (1977b) & \multicolumn{2}{|c|}{$\begin{array}{l}\text { Piasecki et al. } \\
\quad(2004)\end{array}$} & \multicolumn{4}{|c|}{ This study } \\
\hline Formation & $\begin{array}{l}\text { Formation/ } \\
\text { Member }\end{array}$ & Formation & Member & $\begin{array}{l}\text { Super- } \\
\text { group }\end{array}$ & Group & Formation & Member \\
\hline & & & & \multirow{9}{*}{$\begin{array}{l}\text { Jameson } \\
\text { Land } \boldsymbol{\nabla}\end{array}$} & \multirow{3}{*}{$\begin{array}{l}\text { Wollaston } \\
\text { Forland }\end{array}$} & \multirow{2}{*}{$\begin{array}{l}\text { Palnatokes } \\
\text { Bjerg }\end{array}$} & Ravn Pynt \\
\hline \multirow[t]{2}{*}{ Kap Hamburg } & & & & & & & Midter Gneisnæs \\
\hline & & & & & & Lindemans Bugt & Niesen \\
\hline \multirow{2}{*}{ Kløft I } & \multirow{2}{*}{ Kløft I } & Bernbjerg & & & \multirow{6}{*}{ Vardekløft $\nabla \triangle$} & Bernbjerg & \\
\hline & & Payer Dal & & & & Payer Dal & \\
\hline \multirow{4}{*}{ Trækpas } & \multirow{4}{*}{$\begin{array}{l}\text { Vardekløft Fm } \\
\text { Pelion Mb }\end{array}$} & \multirow{2}{*}{ Pelion } & Spath Plateau & & & \multirow{2}{*}{ Pelion $\boldsymbol{\nabla}$} & \multirow[t]{4}{*}{ Spath Plateau } \\
\hline & & & & & & & \\
\hline & & & & & & Muslingebjerg $\nabla$ & \\
\hline & & & & & & Bastians Dal & \\
\hline
\end{tabular}

\begin{tabular}{|c|c|c|c|c|c|c|}
\hline \multicolumn{7}{|c|}{$\begin{array}{l}\text { Jurassic - lowermost Cretaceous of Hold with Hope, Clavering } \varnothing \text {, } \\
\text { Wollaston Forland, Kuhn } \varnothing \text { and Hochstetter Forland }\end{array}$} \\
\hline \multicolumn{3}{|c|}{ Surlyk (1977b, 1978b) } & \multicolumn{4}{|c|}{ This study } \\
\hline Group & Formation & Member & $\begin{array}{l}\text { Super- } \\
\text { group }\end{array}$ & Group & Formation & Member \\
\hline \multirow{7}{*}{$\begin{array}{c}\text { Wollaston } \\
\text { Forland }\end{array}$} & \multirow{4}{*}{$\begin{array}{l}\text { Palnatokes } \\
\text { Bjerg }\end{array}$} & Rødryggen & \multirow{14}{*}{$\begin{array}{l}\text { Jameson } \\
\text { Land } \nabla\end{array}$} & \multirow{7}{*}{$\begin{array}{l}\text { Wollaston } \\
\text { Forland }\end{array}$} & \multirow{4}{*}{$\begin{array}{l}\text { Palnatokes } \\
\text { Bjerg }\end{array}$} & Rødryggen \\
\hline & & Albrechts Bugt & & & & Albrechts Bugt \\
\hline & & Falske Bugt & & & & Falskebugt \\
\hline & & Young Sund & & & & Young Sund \\
\hline & \multirow{3}{*}{$\begin{array}{l}\text { Lindemans } \\
\text { Bugt }\end{array}$} & Niesen & & & \multirow{3}{*}{$\begin{array}{l}\text { Lindemans } \\
\text { Bugt }\end{array}$} & Niesen \\
\hline & & Rigi & & & & Rigi \\
\hline & & Laugeites Ravine & & & & Laugeites Ravine \\
\hline \multirow{6}{*}{$\begin{array}{l}\text { Jameson } \\
\text { Land }\end{array}$} & \multirow[t]{2}{*}{ Bernbjerg } & & & \multirow{7}{*}{ Vardekløft $\nabla \triangle$} & \multirow[t]{2}{*}{ Bernbjerg } & \\
\hline & & & & & & Ugpik Ravine $\bigcirc$ \\
\hline & \multirow{4}{*}{ Vardekløft } & Jakobsstigen & & & Jakobsstigen $\boldsymbol{\nabla}$ & \\
\hline & & \multirow{2}{*}{ Pelion } & & & Payer Dal & \\
\hline & & & & & Pelion $\nabla \Delta$ & Spath Plateau \\
\hline & & Muslingebjerg & & & Muslingebjerg $\mathbf{\nabla}$ & \\
\hline & & & & & Bastians Dal & \\
\hline
\end{tabular}

\begin{tabular}{|c|c|c|c|c|c|c|}
\hline \multicolumn{7}{|c|}{ Jurassic - lowermost Cretaceous of Traill $\varnothing$ and Geographical Society $\varnothing$} \\
\hline \multicolumn{3}{|c|}{ Surlyk (1977b) } & \multicolumn{4}{|c|}{ This study } \\
\hline Group & Formation & Member & $\begin{array}{l}\text { Super- } \\
\text { group }\end{array}$ & Group & Formation & Member \\
\hline \multirow{8}{*}{$\begin{array}{c}\text { Jameson } \\
\text { Land }\end{array}$} & \multirow[b]{3}{*}{ Bernbjerg } & & \multirow{8}{*}{$\begin{array}{l}\text { Jameson } \\
\text { Land } \nabla\end{array}$} & \multirow{2}{*}{$\begin{array}{c}\text { Wollaston } \\
\text { Forland }\end{array}$} & \multirow{2}{*}{$\begin{array}{l}\text { Palnatokes } \\
\text { Bjerg }\end{array}$} & Rødryggen \\
\hline & & & & & & Albrechts Bugt \\
\hline & & & & \multirow{6}{*}{ Vardekløft $\boldsymbol{\nabla} \Delta$} & Bernbjerg & \\
\hline & \multirow{5}{*}{ Vardekløft } & & & & Olympen & \\
\hline & & & & & Fossilbjerget $\boldsymbol{\nabla}$ & \\
\hline & & \multirow{3}{*}{ Pelion } & & & \multirow{2}{*}{ Pelion $\nabla$} & Parnas $O$ \\
\hline & & & & & & \\
\hline & & & & & Bristol Elv & \\
\hline
\end{tabular}

Fig. 3 (continued) Stratigraphical scheme showing older subdivisions together with the revised subdivision presented in this study, covering Jameson Land, Milne Land, Traill $\varnothing$, Geographical Society $\varnothing$, Hold with Hope, Clavering $\varnothing$, Wollaston Forland, Kuhn $\varnothing$, Hochstetter Forland, Store Koldewey and Germania Land. 
Thickness. 1100-2400 $\mathrm{m}$ in the Jameson Land Subbasin. Greater thicknesses are reached in the Wollaston Forland area.

Lithology. The Kap Stewart Group at the base is terrestrial and consists of alluvial fan, fluvial and deltaic conglomerates and sandstones, passing basinwards into lacustrine black mudstones. A tidally influenced marginal marine interlude has, however, been recognised in central and northern Jameson Land. The remainder of the supergroup consists almost exclusively of marine conglomerates, sandstones, heteroliths and mudstones.

Boundaries. The supergroup unconformably overlies the Triassic Scoresby Land Group, which includes the youngest red-beds and dolomites of the Jameson Land area and older rocks farther north, in places with erosional unconformity. The supergroup is the youngest preserved unit in Jameson Land. It is overlain by the mudstone-dominated Lower Cretaceous Brorson Halvø Group in the Traill $\varnothing$, Hold with Hope and Wollaston Forland areas. In other areas, the supergroup is unconformably overlain by Quaternary deposits or forms the present-day erosional topographic surface.

Distribution. The supergroup is widely distributed in East Greenland (central East Greenland and North-East Greenland of Ghisler 1990), from Jameson Land and Milne Land in the south to Store Koldewey and Germania Land in the north (Fig. 1).

\section{Chronostratigraphy. Rhaetian - lower Hauterivian.}

Subdivision. The supergroup is subdivided (from below) into the Kap Stewart (Rhaetian-Sinemurian), Neill Klinter (Pliensbachian - lower Bajocian), Vardekløft (upper Bajocian - Ryazanian), Hall Bredning (upper Callovian - Hauterivian), and Wollaston Forland (middle Volgian lower Hauterivian) Groups.

\section{Kap Stewart Group}

revised unit

History. The Kap Stewart Formation was erected by Rosenkrantz (1929) and revised by Surlyk et al. (1973). Harris (1937) subdivided the formation into a 'barren sandstone' below and a 'plant-bearing series' above, and these units to some extent correspond to two of the three new formations of the group.

Type locality. Coastal cliff at Kap Stewart, south-eastern corner of Jameson Land, $70^{\circ} 26.7^{\prime} \mathrm{N}, 22^{\circ} 37.8^{\prime} \mathrm{W}$. The lower boundary dips below the sea in this area.
The upper boundary is well exposed at Tancrediakløft, south-eastern Jameson Land (Fig. 2a). For details, see component formations.

Reference sections. Ranunkeldal, Horsedal, Rhætelv, Lepidopteriselv, Primulaelv, Astartekløft and Qupaulakajik (Fig. 2a). See under the individual formations.

Thickness. At outcrop, the group is typically 155-300 m thick, increasing from south to north and from the eastern and western margins to the centre of the basin. In the outlier in south Liverpool Land, it is only 20 m thick. Seismic data show that the thickness may exceed $500 \mathrm{~m}$ in the central parts of the basin (Dam et al. 1995).

Lithology. Conglomerates, arkosic sandstones, dark plant-bearing mudstones and a few thin coal beds in south-eastern Jameson Land. Towards the north and in central Jameson Land, thick units of black finely laminated lacustrine mudstones alternate with lake delta sheet sandstones (see Figs 5, 7, 10).

Fossils. Abundant plants, spores and pollen. Almost barren of invertebrate fossils, but scattered bivalves, gastropods, ostracods, fish scales and spines, coprolites, rare insects and trace fossils occur.

Depositional environment. Mainly terrestrial. Depositional settings included alluvial fans, braided and meandering streams, distributary channels and interdistributary bays along the basin margins, and a stratified anoxic lake in the centre of the Jameson Land Subbasin. Tidally influenced deposits have, however, been identified in the lower part of the group in central and northern Jameson Land by Clemmensen (1976) and Surlyk (unpublished observations at Ranunkeldal).

Boundaries. Overlies red marly mudstones and grey carbonates of the Norian Fleming Fjord Group. The lower boundary is mainly poorly exposed or obscured by Palaeogene volcanic intrusions. The boundary is placed at the base of the lowest yellowish fluvial sandstones or greyish to black mudstones overlying the carbonate deposits of the Tait Bjerg Member or the reddish and greenish mudstones and sandstones of Ørsted Dal Formation, both of the underlying Fleming Fjord Group (Clemmensen et al. 2020). Along the eastern basin margin, the upper boundary is placed at an erosional unconformity separating polymict pebble conglomerates of the Rævekløft Formation (Neill Klinter Group) above from sandstones of the Kap Stewart Group below. In the central and northern parts of the basin, the Kap Stewart Group is conformably overlain by bioturbated, fossiliferous sandstones of the Elis Bjerg Member (Gule Horn 


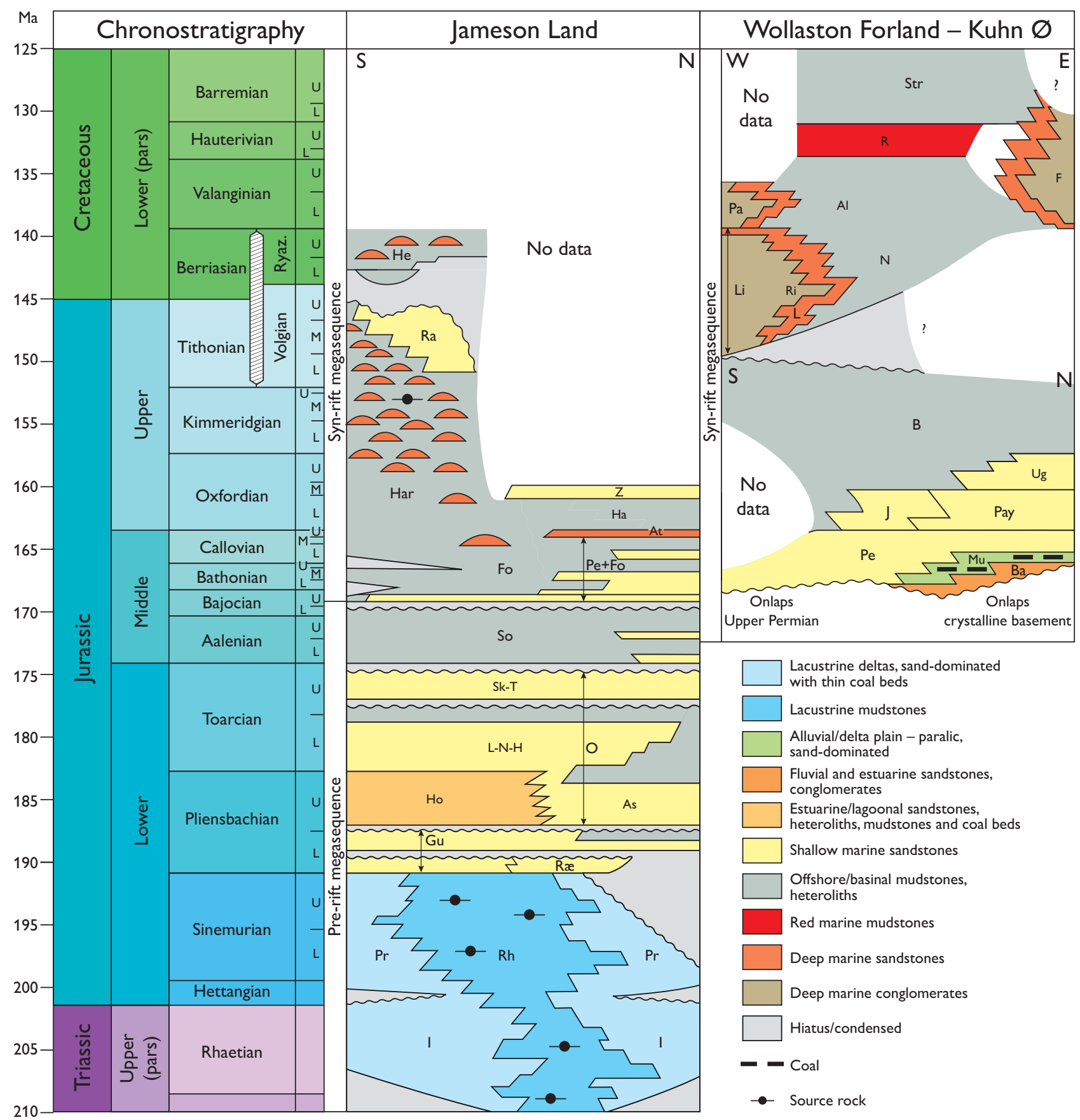

Fig. 4 Chronostratigraphic scheme of the uppermost Triassic - lowermost Cretaceous successions of East Greenland, showing the main lithologies, depositional environments and tectonostratigraphic sequences. Al: Albrechts Bugt Member. As: Astartekløft Member. At: Athene Member. B: Bernbjerg Formation. Ba: Bastians Dal Formation. F: Falskebugt Member. Fo: Fossilbjerget Formation. Gu: Gule Horn Formation. Ha: Hades Member. Har: Hareelv Formation. He: Hesteelv Formation. Ho: Horsedal Member. I: Innakajik Formation. J: Jakobsstigen Formation. L: Laugeites Ravine Member. Li: Lindemans Bugt Formation. L-N-H: Lepidopteriselv, Nathorst Fjeld and Harris Fjeld Members. N: Niesen Member. Mu: Muslingebjerg Formation. O: Ostreaelv Formation. Pa: Palnatokes Bjerg Formation. Pay: Payer Dal Formation. Pe: Pelion Formation. Pr: Primulaelv Formation. R: Rødryggen Member. Ra: Raukelv Formation. Rh: Rhætelv Formation. Ri: Rigi Member. Ræ: Rævekløft Formation. Sk-T: Skævdal and Trefjord Bjerg Members. So: Sortehat Formation. Str: Stratumbjerg Formation. Ug: Ugpik Ravine Member. Z: Zeus Member.

Formation, Neill Klinter Group). The boundary is relatively sharp, but no hiatus appears to be present and the sharp transition probably reflects marine inundation of the basin.
Distribution. Jameson Land. A small down-faulted outlier occurs in southernmost Liverpool Land (Fig. 1).

Chronostratigraphy. Rhaetian-Sinemurian, based on macroflora, spores and pollen. In south-eastern Jameson 
Land, along the basin margin, the boundary to the overlying Neill Klinter Group conceals a hiatus corresponding to the Sinemurian Stage as shown by combined evidence from ammonites, macroflora and palynology.

Subdivision. The group is subdivided into the Innakajik, Primulaelv and Rhætelv Formations.
Key references. Harris (1937 and references therein), Rosenkrantz (1942), Surlyk et al. (1971, 1973), Sykes (1974a), Clemmensen (1976), Pedersen \& Lund (1980), Dam \& Christiansen (1990), Dam \& Surlyk (1992, 1993, 1995, 1998), Dam et al. (1995), Mathiesen et al. (1995), Krabbe (1996), Lindgreen \& Surlyk (2000), Hesselbo et al. (2002), Surlyk (2003), McElwain et al. (2007, 2009), McElwain \& Punyasena (2007), Popa \& McElwain (2009),
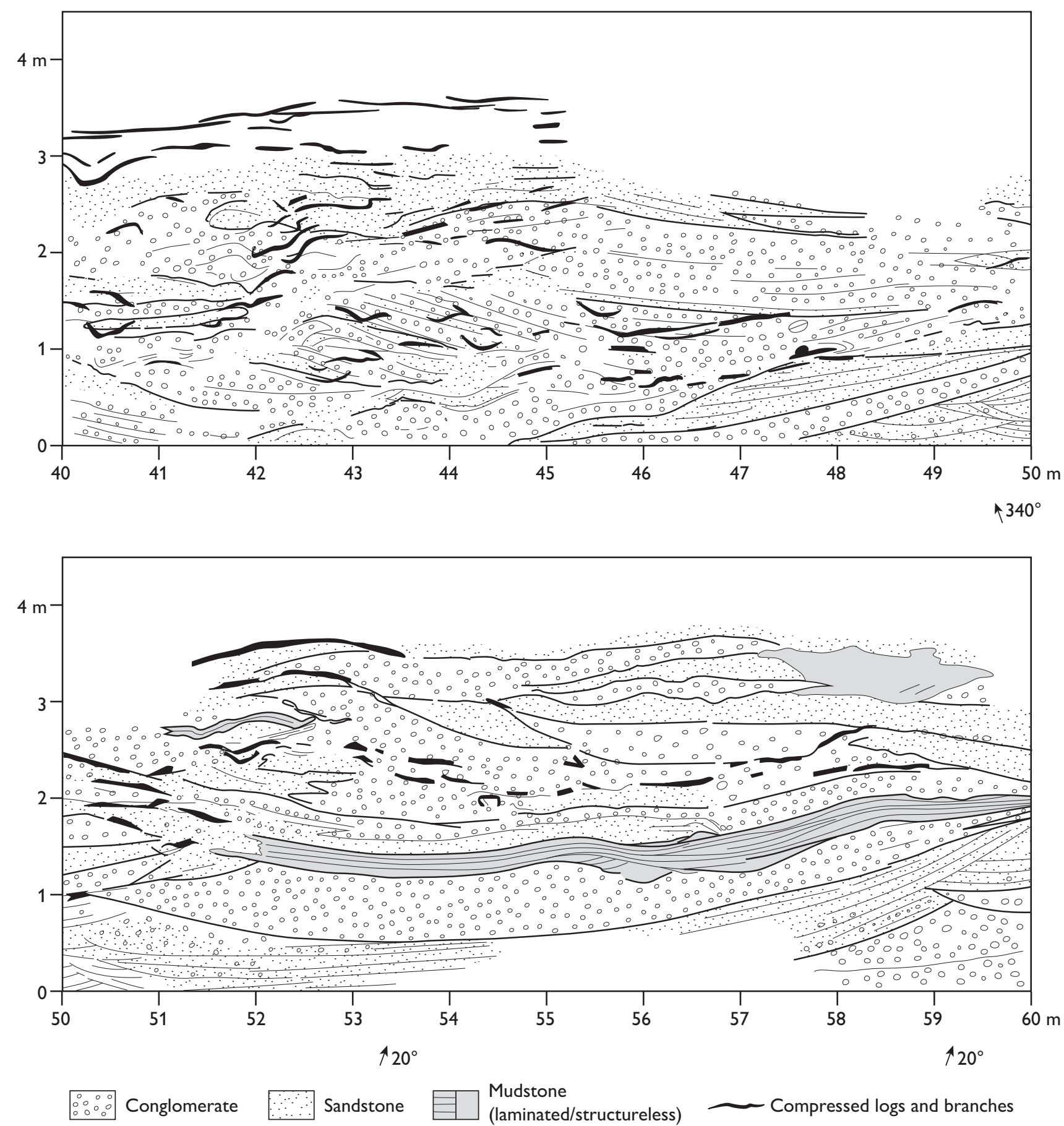

Fig. 5 Lateral profile of the type section of the Innakajik Formation, part of a $200 \mathrm{~m}$ long measured profile along the coastal cliff at Kap Stewart (Innakajik), Jameson Land (Figs 1, 2a). 
Mander et al. (2010, 2013), Milàn et al. (2012), Steinthorsdottir et al. (2012, 2015), Kürschner et al. (2014), Pott (2014), Williford et al. (2014), Kelly et al. (2015), Hansen et al. (2016), Decou et al. (2017).

\section{Innakajik Formation \\ new formation}

History. The formation corresponds roughly to the "barren sandstones' of Harris (1937), see also Surlyk et al. (1971) and Pedersen \& Lund (1980). The term 'barren' refers to the lack of well-preserved plant fossils.

Name. After Innakajik, the Greenlandic name for Kap Stewart.

Type section. The coastal cliff at Innakajik (Kap Stewart), $70^{\circ} 26.7^{\prime} \mathrm{N}, 22^{\circ} 37.8^{\prime} \mathrm{W}$ (Figs 2a, 5). Neither the lower nor the upper boundary are exposed in this section.

Reference section. Mouth of the Ranunkeldal valley (Fig. 2a).

Thickness. $85 \mathrm{~m}$ are exposed at the type section, and more than $150 \mathrm{~m}$ at Ranunkeldal.

Lithology. Disorganised pebble and cobble conglomerates, with common large branches, twigs and organic debris. Bedding is extremely irregular and bed boundaries are strongly curved, forming both erosional concave-up or depositional convex-up surfaces. The conglomerates alternate with multistorey pebbly sandstones, thin coaly horizons and localised erosional remnants of dark grey mudstones (Figs 5, 6).

Fossils. Rare plants, spores and pollen.

Depositional environment. Alluvial fan and braided to low-sinuosity rivers.

Boundaries. The lower boundary is rarely exposed. In the area just north of the type section, it appears to be conformable and is placed at the base of yellow sandstones and dark mudstones, overlying reddish and greenish mudstones and sandstones of the Ørsted Dal Formation or the undifferentiated Fleming Fjord Group. Farther north, the lower boundary is placed at the base of the lowest yellowish fluvial sandstones or greyish to black mudstones, overlying carbonate deposits of the Tait Bjerg Member of the Fleming Fjord Group. The upper boundary is placed at the base of the lowest sandy fining-upward sandstone-mudstone units or plant-rich mudstones of the Primulaelv Formation.

Distribution. South-eastern and western Jameson Land (Figs 1, 2a); the formation wedges out towards the basin centre, interdigitating with the Rhætelv Formation (Fig. 4).

Chronostratigraphy. Rhaetian, based on spores and pollen.

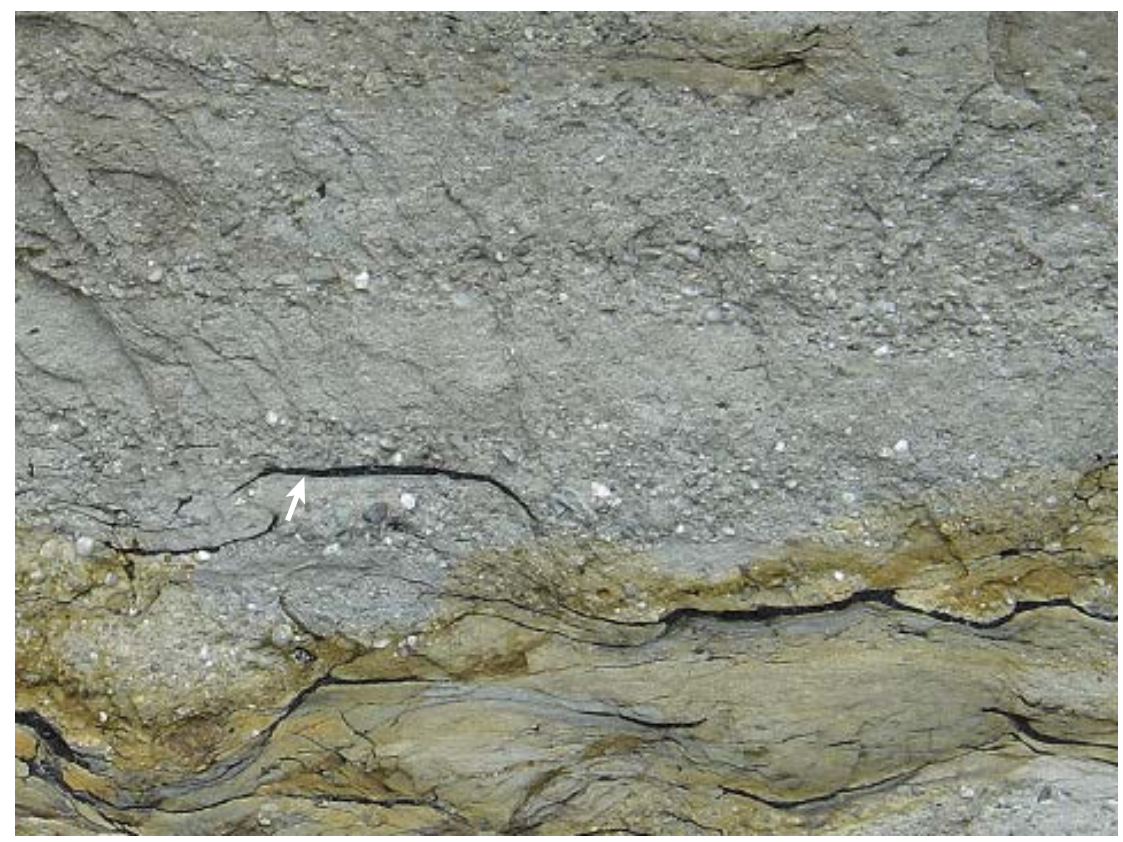

Fig. 6 Conglomerates, pebbly sandstones and compressed coalified branches and logs deposited in alluvial fan and braided river environments. Black horizontal log (arrowed) is about $1 \mathrm{~m}$ long. Type section of the Innakajik Formation, Kap Stewart, southernmost Jameson Land (Figs 1, 2a). 


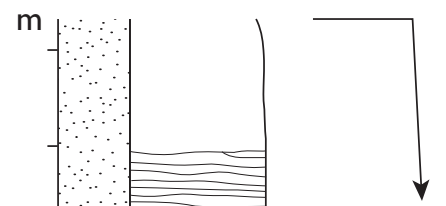

1

20

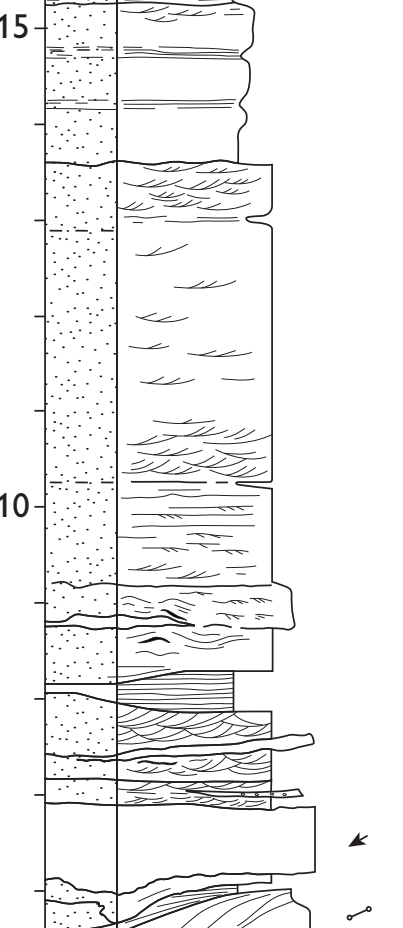

5

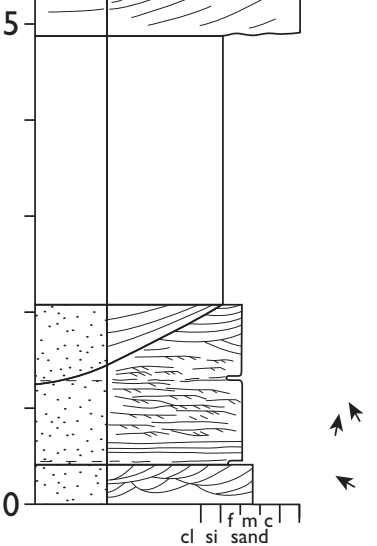

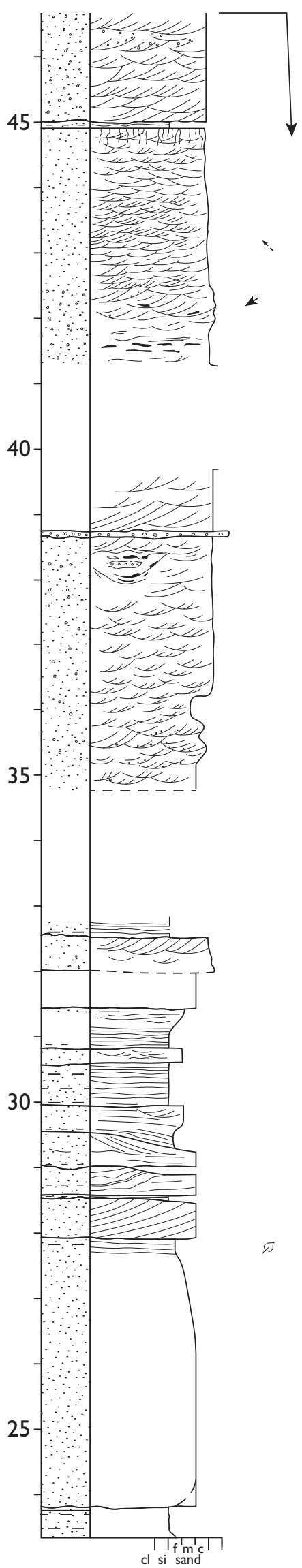

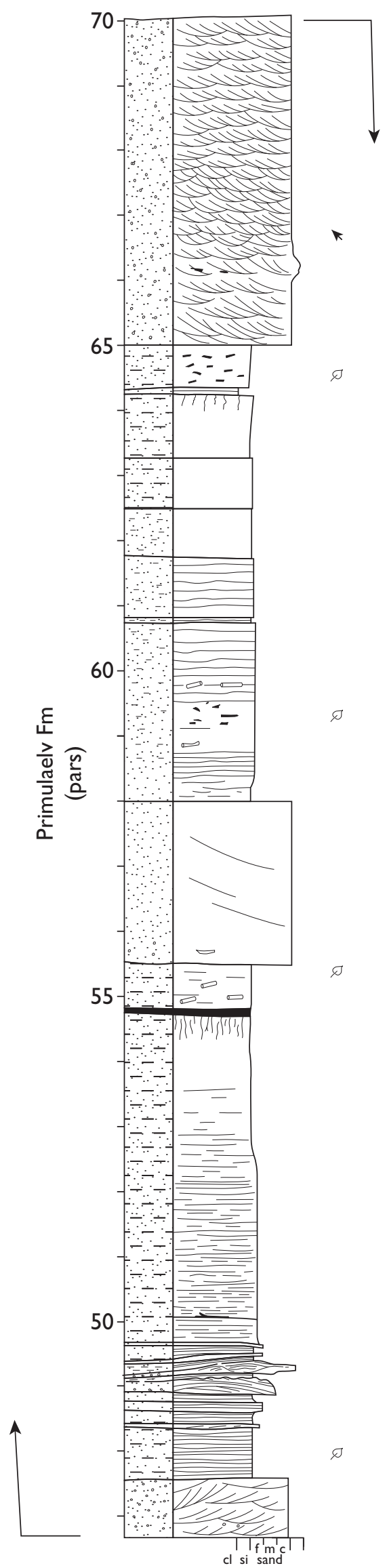

Fig. 7 Type section of the Primulaelv Formation. Tancrediakløft, Jameson Land (Figs 1, 2a). The accompanying legend (following page) is applicable to all sedimentary logs in the bulletin. 

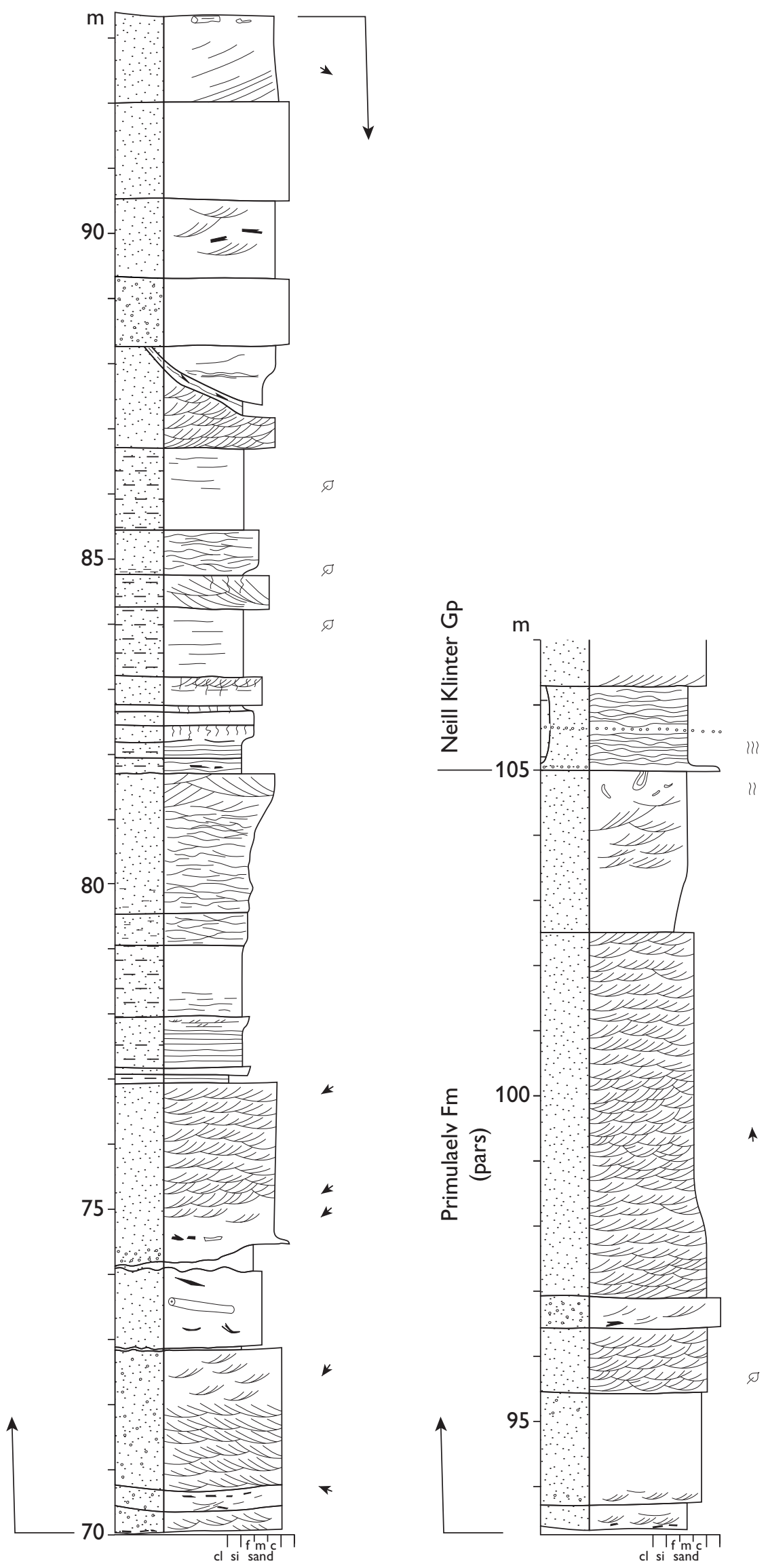

Fig. 7 (continued) Type section of the Primulaelv Formation. Tancrediakløft, Jameson Land (Figs 1, 2a). The accompanying legend (following page) is applicable to all sedimentary logs in the bulletin. 


\section{Legend to Fig. 7}

\section{Lithology}

\begin{tabular}{|c|c|}
\hline & Coal \\
\hline & Claystone \\
\hline & Mudstone \\
\hline & Mudstone \\
\hline & Heterolith \\
\hline & Muddy sandstone \\
\hline & Sandstone \\
\hline & Pebbly sandstone \\
\hline & $\begin{array}{l}\text { Sideritic rip-up mudstone } \\
\text { clasts/conglomerate }\end{array}$ \\
\hline & Conglomerate, sandstone matrix \\
\hline & Concretion \\
\hline & Concretionary horizon \\
\hline-- & Mudstone clasts \\
\hline … & Carbonaceous material \\
\hline & Pyritic mudstone \\
\hline$x^{x} \times x^{x}$ & Glauconite \\
\hline
\end{tabular}

\section{Bed contacts}

$\sim$ Sharp/erosional or irregular

- Sharp planar

- - Gradational

\section{Sedimentary structures}

Cross-bedding with double mud-drapes
Clong foresets

\section{Trace fossils}

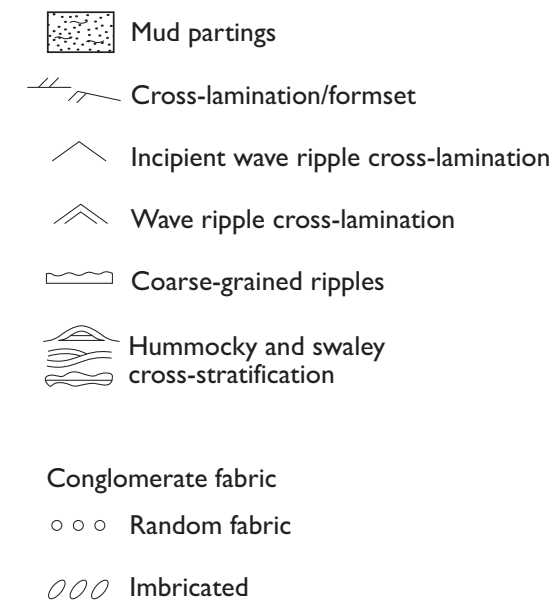

Biota

$$
\begin{gathered}
A Y\{\text { Rootlets } \\
* \text { Plant fragments } \\
\sim \text { Logs and branches } \\
\approx \text { Drifted plant stems/logs }
\end{gathered}
$$$$
\text { 近 B Bivalves }
$$

Q) Gastropods

(2) Ammonites

$\checkmark \leadsto Y$ Belemnites

(1) $(\mathbb{1}$ Brachiopods

* W Crinoids

$$
\begin{aligned}
& \propto \text { Echinoderms } \\
& ₫ \text { Corals } \\
& \propto \text { Fish } \\
& \approx \approx \text { Shell fragments }
\end{aligned}
$$

\section{Palaeocurrents, miscellaneous}

$$
\begin{aligned}
& \text { Clinoform orientation } \\
& \text { Foreset orientation (cross- } \\
& \text { lamination, cross-bedding) } \\
& \text { Crestline orientation of wave } \\
& \text { ripples }
\end{aligned}
$$

$\left.\begin{array}{ll}\int & \text { Weak } \\ \iint_{\int S S} & \text { Moderate } \\ \text { Intense }\end{array}\right\}$ bioturbation

$\cup \cup$ Arenicolites isp.

$y_{4}$ Chondrites isp.

(4) es Curvolithos multiplex

Y Diplocraterion isp.

$\forall$ Diplocraterion parallelum

(m) Gyrochorte comosa

Gyrochorte isp.

$\sim$ Helminthoida isp.

§. Helminthopsis magna

Y Monocraterion isp.

9 Monocraterion tentaculatum

(CO) Nereites isp.

Ophiomorpha nodosa

$\odot \Longleftarrow$ Palaeophycus herberti

澡 Phoebichnus trochoides

Phycodes isp.

Planolites isp.

g. Skolithos isp.

() Spirophycus isp.

(8) Taenidium serpentinum

Seichichnus isp.

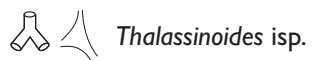

U Tisoa habichi

Zoophycos isp.

$\approx$ Escape burrow

Unidentified sinuous

horizontal burrow 


\section{Primulaelv Formation}

new formation

History. Corresponds broadly to the 'plant-bearing series' of Harris (1937). The macroplant flora indicates that the 'barren sandstone' and the lowest $30 \mathrm{~m}$ of the 'plant-bearing series' belong to the Lepidopteris floral zone (Rhaetian). Above a c. $5 \mathrm{~m}$ transition zone, the remaining $55 \mathrm{~m}$ of the 'plant-bearing series' belong to the Hettangian Thaumatopteris floral zone (Harris 1937). This floral change occurred synchronously with a light carbon isotope excursion, suggesting a causal link between the loss of taxa and the very earliest eruptive phases of the Central Atlantic magmatic province (Hesselbo et al. 2002).

Name. After the Primulaelv river, south-eastern Jameson Land (Fig. 2a).
Type section. Tancrediakløft, $70^{\circ} 30.7^{\prime} \mathrm{N}, 22^{\circ} 37.4^{\prime} \mathrm{W}$ (Figs $2 a, 7)$.

Reference sections. South side of the Astartekløft valley (Figs 2a, 8). Southern bank at the mouth of the Primulaelv river, and GGU slim-hole well core, Hareelv No. 303128 (accessible for study at the Geological Survey of Denmark and Greenland, Copenhagen, Denmark).

Thickness. About $105 \mathrm{~m}$.

Lithology. Pebbly to fine-grained sandstones, which commonly form fining-upwards units, passing up into black to dark grey mudstones, thin coal beds and rootlet horizons.

Fossils. Abundant plants, spores and pollen, rare insects and fish scales.

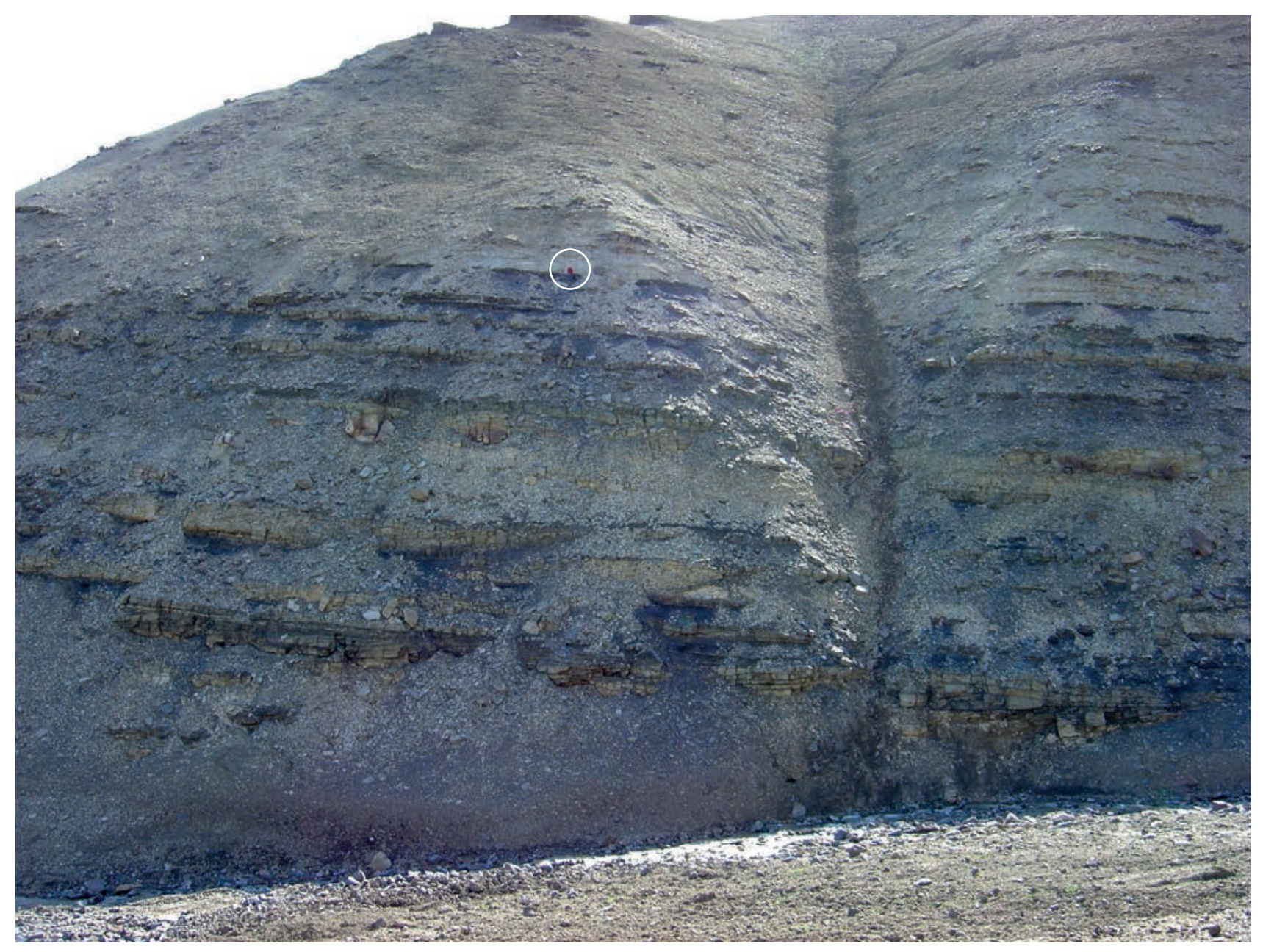

Fig. 8 The Primulaelv Formation at Astartekløft, southern Jameson Land (Figs 1, 2a). The lower part shows alternating, sandstones and dark mudstones deposited in meandering rivers and backswamps. This is overlain by coarse-grained pebbly sandstones and the boundary corresponds to the boundary between the Rhaetian Lepidopteris zone and the Lower Jurassic Thaumatopteris zone. Person at boundary for scale (encircled). 


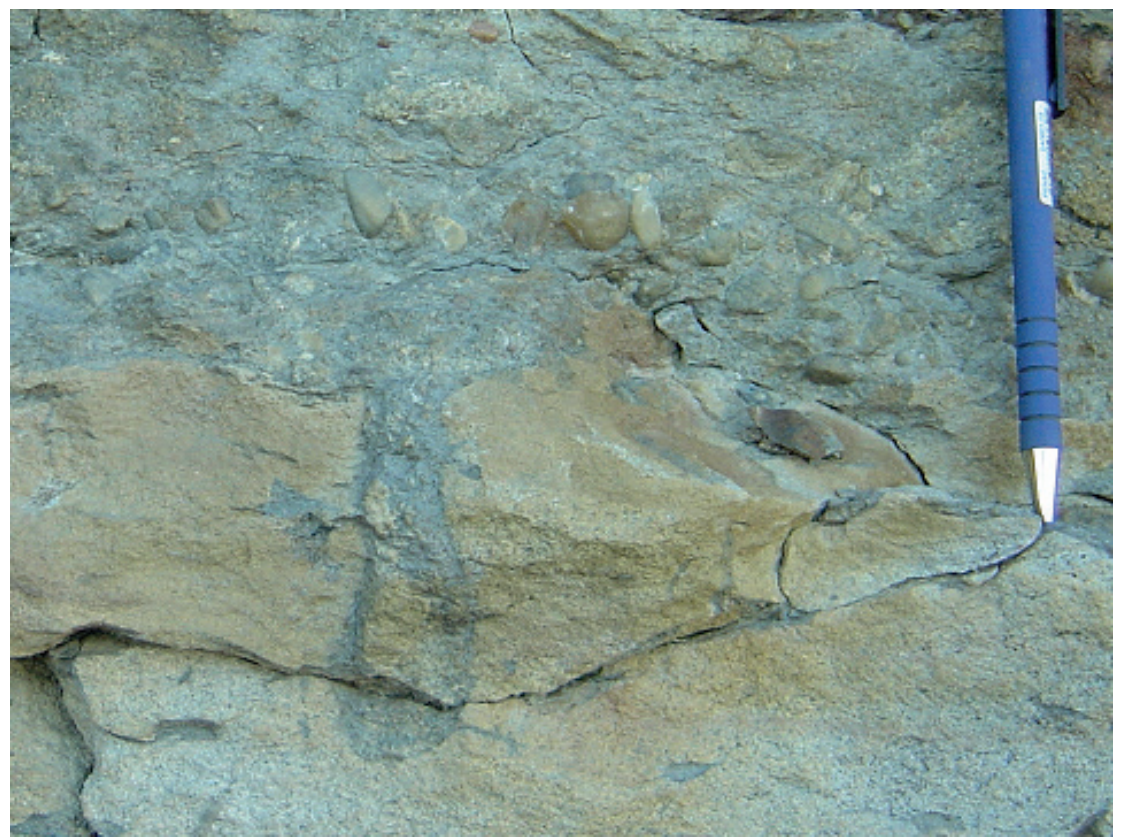

Fig. 9 The boundary between the Kap Stewart and Neill Klinter Groups marked by an erosion surface with a truncated Diplocraterion burrow, overlain by a fossiliferous lag pebble conglomerate of the Rævekløft Formation, Neill Klinter Group (Fig. 7). Pencil for scale, $15 \mathrm{~cm}$ long. Tancrediakløft, Jameson Land (Figs 1, 2a).

Depositional environment. Meandering rivers, crevasse splays, delta plain. Tidally influenced marginal marine deposits have been identified in central and northern Jameson Land by Clemmensen (1976) and Surlyk (unpublished observations at Ranunkeldal).

Boundaries. The lower boundary is defined by the base of the lowest plant-bearing beds, in situ coal beds or well-developed fining-upwards sandstone-mudstone units, overlying the conglomerate-dominated Innakajik Formation. Towards the basin centre, the Primulaelv Formation interfingers with the Rhætelv Formation and here the boundary is drawn somewhat arbitrarily at the base of the lowest black organic-rich mudstones. Along the eastern basin margin, the upper boundary is defined at the erosional unconformity that marks the base of marine pebbly sandstones and heteroliths of the Rævekløft Formation (Neill Klinter Group; Fig. 9). In the basin centre, the boundary is defined by the base of the lowest bed with marine trace fossils referred to the basal Gule Horn Formation (Neill Klinter Group).

Distribution. South-eastern Jameson Land (Figs 1, 2a). Wedges out towards the basin centre where it interfingers with the Rhætelv Formation (Fig. 4).

Chronostratigraphy. Rhaetian-Hettangian, based on macroplants, spores and pollen. Probably includes the Sinemurian in the basin centre and in the subsurface.

\section{Rhætelv Formation}

new formation

Name. After the Rhætelv river in northern Jameson Land (Fig. 2a).

Type section. Cliffs north-west of Rhætelv, $71^{\circ} 38.8^{\prime} \mathrm{N}$, 23⒘2'W (Fig. 10).

Reference sections. Lepidopteriselv, Horsedal and mouth of Ranunkeldal (Fig. 2a).

Thickness. 150-300 m.

Lithology. Black, finely laminated mudstones alternating with sheet sandstones, which are commonly capped by rootlet horizons and thin coaly beds (Fig. 11).

Fossils. Fossils are mainly lacking, but rare bivalves, gastropods, ostracods, fish scales and spines, coprolites, plants, spores, pollen and trace fossils do occur.

Depositional environment. The mudstones were deposited in a deep lake with anoxic bottom conditions, whereas the sheet sandstones represent shallow-water lacustrine deltas.

Boundaries. In the central and northern parts of the basin, the lower boundary is mainly poorly exposed or obscured by Palaeogene volcanic intrusions. The boundary is placed at the base of the lowest yellowish fluvial sandstone or greyish to black mudstones, overlying the carbonate deposits of the Tait Bjerg Member (Fleming 


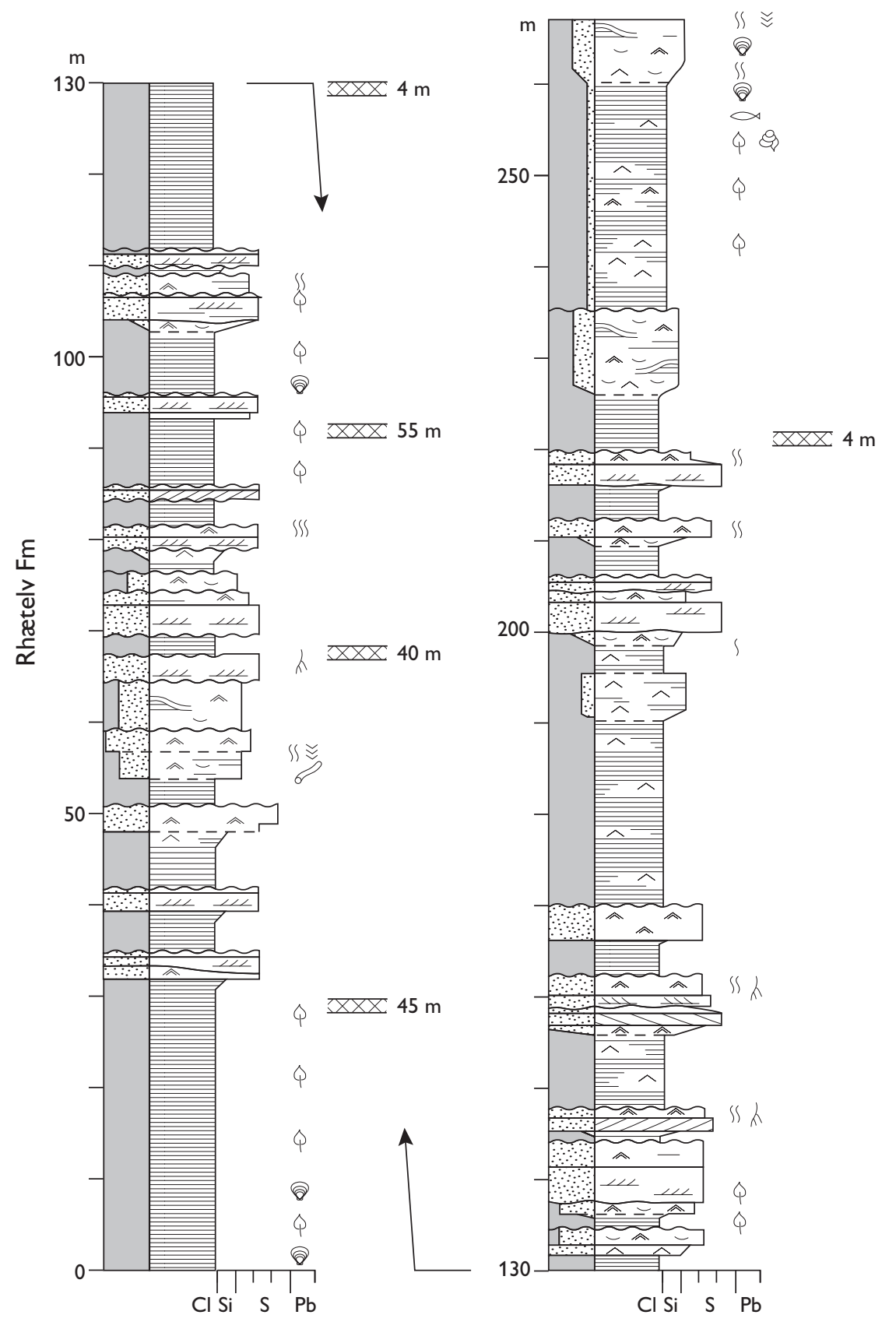

Fig. 10 Type section of the Rhætelv Formation, Rhætelv, Jameson Land (Figs 1, 2a). Modified from Dam \& Surlyk (1993, fig. 3). For legend, see Fig. 7; the crossed bar symbol adjacent to the log indicates the position of intrusive sills cutting the section.

Fjord Group). In the western part of the basin, the lower boundary is poorly exposed but is placed at the base of the lowest coal bed, plant-bearing bed or black mudstone of the Rhætelv Formation. Towards the eastern basin margin, the formation interfingers with the Primulaelv Formation and the lower boundary is here placed at the base of the lowest fining-upwards sandstone, overlying black organic-rich mudstones.
Distribution. Central and northern Jameson Land (Figs 1, 2a). The Rhætelv Formation interdigitates with the Innakajik and Primulaelv Formations towards the basin margins (Figs 1, 4).

Chronostratigraphy. Rhaetian-Sinemurian, based on macroflora, spores and pollen. 


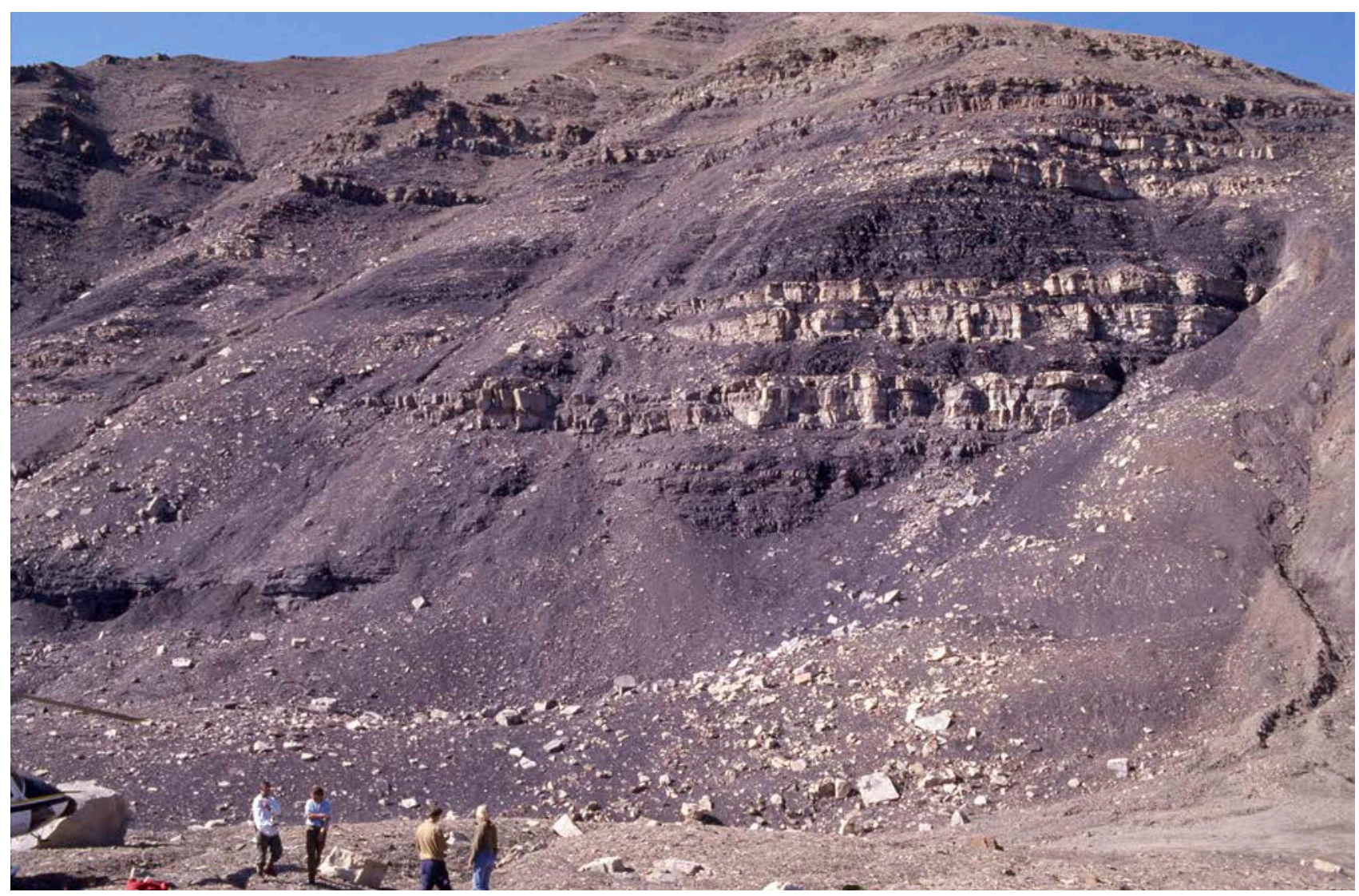

Fig. 11 The Rhætelv Formation, showing alternating deltaic sheet sandstones and lacustrine deep-water black mudstones. Rhætelv, central Jameson Land (Figs 1, 2a).

\section{Neill Klinter Group}

History. Erected as a formation by Rosenkrantz (1929) and revised by Surlyket al. (1973). Elevated to group status by Dam \& Surlyk (1998), who included the Sortehat Member (elevated to formation status) in the new group. The former Sortehat Member previously constituted the basal member of the overlying Vardekløft Formation of Surlyk et al. (1973).

Type locality. The coastal cliffs of Neill Klinter, south-east Jameson Land, $70^{\circ} 37.8^{\prime} \mathrm{N}, 2^{\circ} 39.7^{\prime} \mathrm{W}$ (Figs 1, 2a, 12).

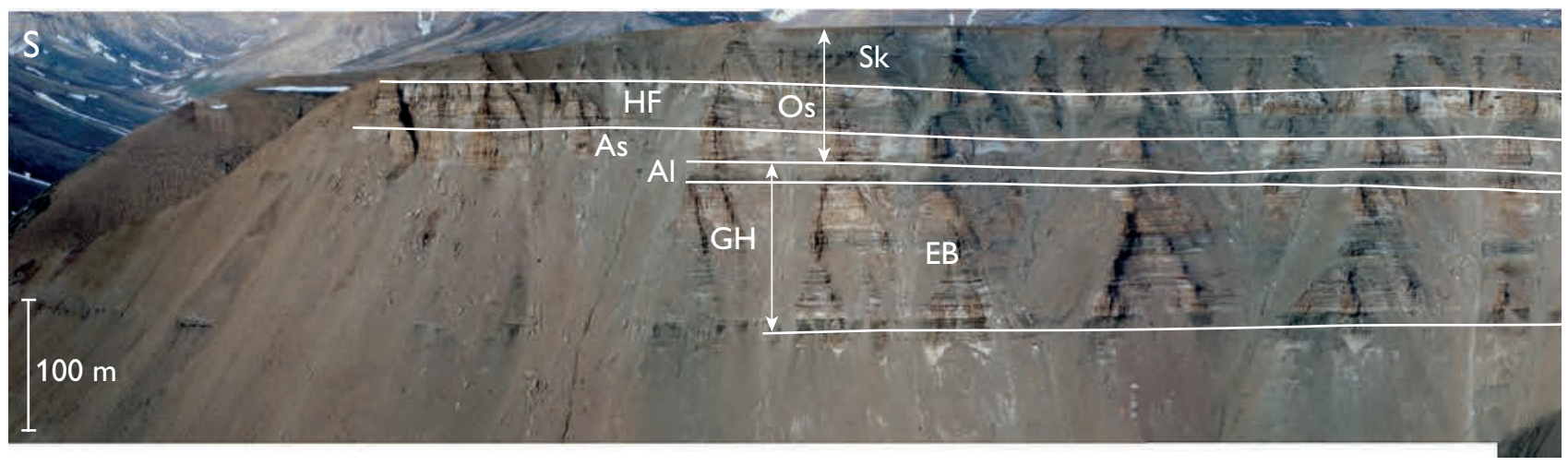

Fig. 12 Aerial photograph of the Neill Klinter Group at Harris Fjeld, Neill Klinter, SE Jameson Land, viewed towards the west (Figs 1 , 2a). KS: Kap Stewart Group. Rk: Rævekløft Formation. GH: Gule Horn Formation (EB: Elis Bjerg Member, Al: Albuen Member). Os: Ostreaelv Formation (As: Astartekløft Member, HF: Harris Fjeld Member, Sk: Skævdal Member). The section from the top of the Kap Stewart Group to the top of the Harris Fjord Member is about 160 m thick (see Fig. 14). Photographed by Torben Olsen. 
Reference sections. Harris Fjeld, Nathorst Fjeld, Elis Bjerg, Lepidopteriselv, Liaselv, Rhætelv, Horsedal and Ranunkeldal (Fig. 2a). See under the individual formations.

Thickness. 300-450 m, increasing towards the basin centre.

Lithology. Thin conglomerates, cross-bedded sandstones, micaceous heteroliths, sandy mudstones and mudstones.

Fossils. Bivalves, gastropods, ammonites, belemnites, echinoids, crinoids, brachiopods, plants, spores, pollen, dinoflagellate cysts and trace fossils.

Depositional environment. Wave, storm and tidally influenced shallow marine embayment.

Boundaries. In south-eastern Jameson Land, the lower boundary is an erosional unconformity, and is placed at the base of the lowest marine conglomerate, cross-bedded sandstone or heterolith, overlying alluvial conglomerates, sandstones or black organic-rich lacustrine mudstones of the Kap Stewart Group. In central and northern Jameson Land, the boundary is conformable and is placed at the base of the lowest marine sandstone or heterolith with marine trace fossils, overlying black mudstones with sheet sandstones of the Rhætelv Formation (Kap Stewart Group). The upper boundary is placed at the base of the lowest marine yellow cross-bedded sandstones of the Pelion Formation (Vardekløft Group), overlying dark mudstones of the Sortehat Formation. In south-eastern Jameson Land, in the coastal cliffs of Neill Klinter, the upper boundary is in some cases developed as a sharp erosional surface separating black mudstones of the Sortehat Formation from a thin greyish silty mudstone with ammonites and marine trace fossils rapidly passing upwards into yellow cross-bedded sandstones of the Vardekløft Group.

Distribution. Restricted to Jameson Land with a small downfaulted outlier in southern Liverpool Land (Figs 1, 2a).

Chronostratigraphy. Pliensbachian - lower Bajocian, based on ammonites, belemnites and dinoflagellate cysts.

Subdivision. The group is subdivided, from below, into the Rævekløft, Gule Horn, Ostreaelv and Sortehat Formations.

Key references. Rosenkrantz (1929, 1934, 1942), Surlyk et al. (1971, 1973), Sykes (1974b), Dam (1990a, b, 1991), Surlyk (1990a, b), Doyle (1991), Callomon (1993), Underhill \& Partington (1994), Krabbe et al. (1994), Dam \& Surlyk (1995, 1998), Hansen (1999), Koppelhus \& Dam (2003), Koppelhus \& Hansen (2003), Surlyk (2003), Nøttvedt et al. (2008), Ahokas et al. (2014), Kelly et al. (2015), Eide et al. (2016), Decou et al. (2017).

\section{Rævekløft Formation}

History. Erected as a member by Surlyk et al. (1973) and elevated to formation rank by Dam \& Surlyk (1998).

Type section. Rævekløft, south-eastern Jameson Land, 70²7.4' N, 22³7.9'W (Surlyk et al. 1973, fig. 7, section 2; Fig. 2a). Note that the type section is situated only a few kilometres from the reference section at Tancrediakløft (Fig. 13) which shows a similar succession in terms of main facies patterns and sedimentological details. The

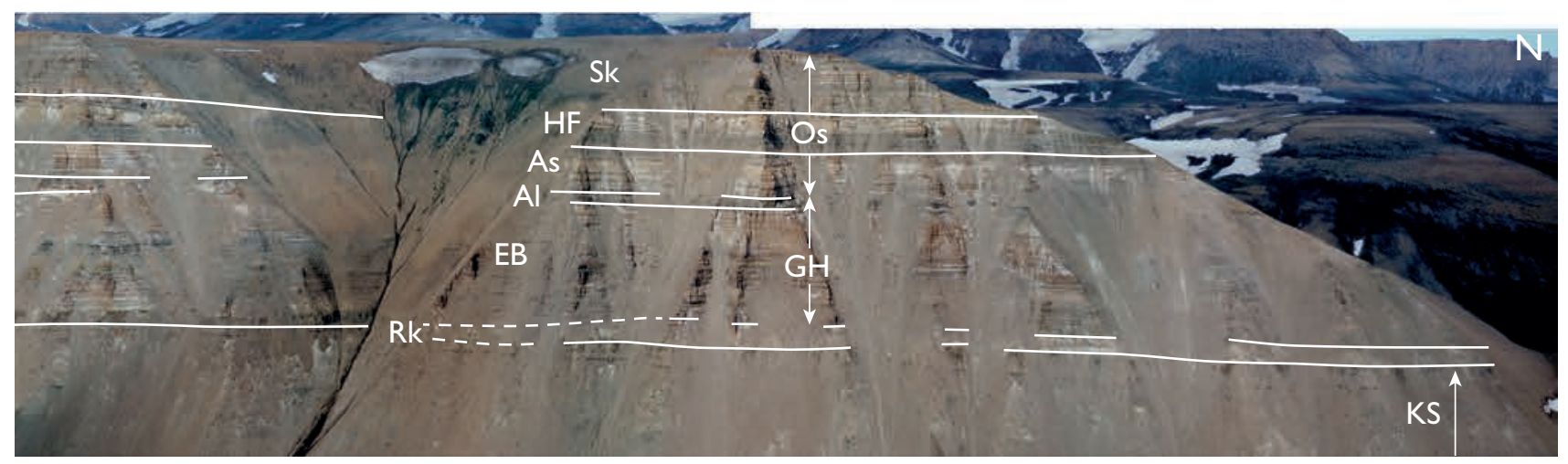

Fig. 12 (continued) Aerial photograph of the Neill Klinter Group at Harris Fjeld, Neill Klinter, SE Jameson Land, viewed towards the west (Figs 1, 2a). KS: Kap Stewart Group. Rk: Rævekløft Formation. GH: Gule Horn Formation (EB: Elis Bjerg Member, Al: Albuen Member). Os: Ostreaelv Formation (As: Astartekløft Member, HF: Harris Fjeld Member, Sk: Skævdal Member). The section from the top of the Kap Stewart Group to the top of the Harris Fjord Member is about $160 \mathrm{~m}$ thick (see Fig. 14). Photographed by Torben Olsen. 


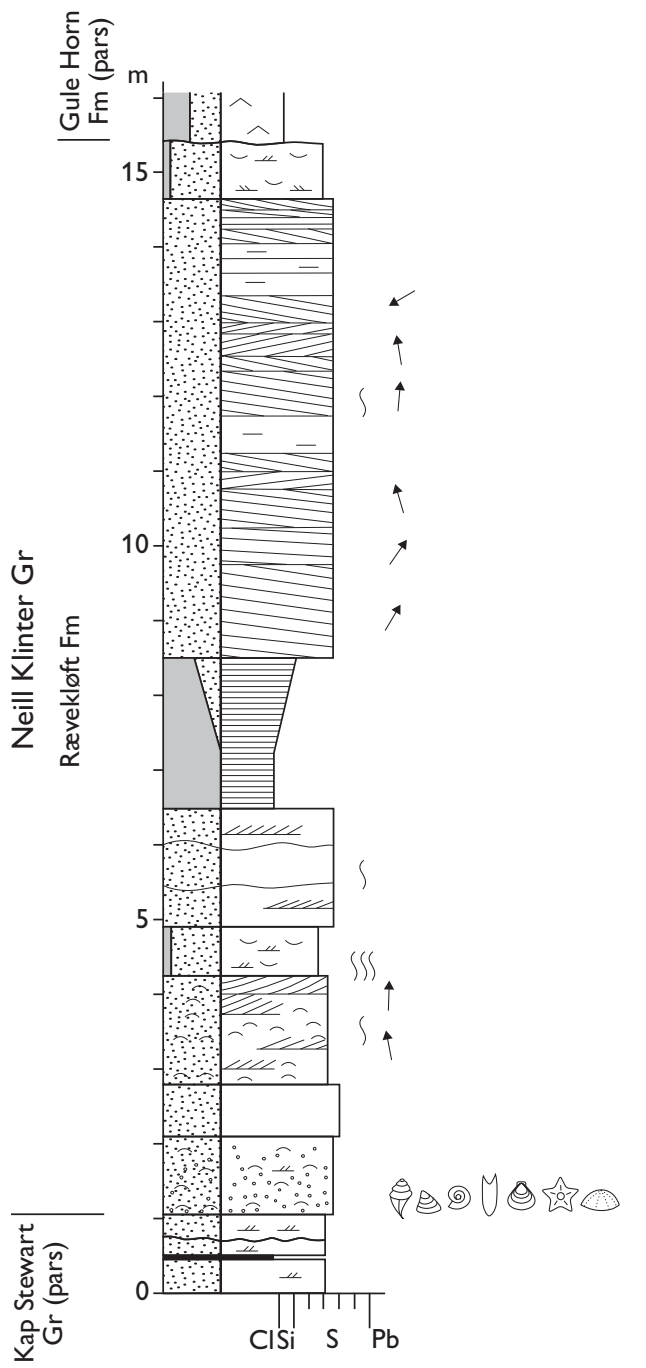

Fig. 13 Reference section of the Rævekløft Formation, Tancrediakløft, Jameson Land (Figs 1, 2a). Modified from Dam \& Surlyk (1993, fig. 7). For legend, see Fig. 7.

generalised type section log in Surlyk et al. (1973, fig. 7, section 2) is thus not reproduced here.

Reference sections. Tancrediakløft (Fig. 13), Qupaulakajik, Harris Fjeld, Elis Bjerg and Kap Hope (Fig. 2a; see Dam \& Surlyk 1998, fig. 7).

\section{Thickness. 9-20 m.}

Lithology. Fossiliferous sandstones, pebbly sandstones and conglomerates.

Fossils. Rich faunas of bivalves, gastropods, ammonites, echinoids and crinoids; trace fossils, spores and pollen.

Depositional environment. Marine shoreface.

Boundaries. In south-east Jameson Land, the lower boundary is placed at an erosional unconformity, separating delta-plain sandstones and conglomerates of the Kap Stewart Group below from the overlying marine fossiliferous conglomerates and sandstones of the Rævekløft Formation. The unconformity marks a hiatus corresponding to the Sinemurian Stage. The upper boundary is a sharp drowning surface overlain by mudstones and heteroliths of the Gule Horn Formation (Elis Bjerg Member).

Distribution. South-eastern Jameson Land (Fig. 1).

Chronostratigraphy. Lower Pliensbachian, U. jamesoni to lower $P$. davoei ammonite zones.

\section{Gule Horn Formation}

History. Erected as a member by Surlyk et al. (1973), elevated to formation rank by Dam \& Surlyk (1998).

Type section. Gule Horn, west of Carlsberg Fjord, $71^{\circ} 20.1^{\prime} \mathrm{N}, 22^{\circ} 43.5^{\prime} \mathrm{W}$ (Surlyk et al. 1973, fig. 8; Fig. 2a). The type section illustrated in Surlyk et al. (1973) is rather generalised and cannot be redrawn in the same style as the other sections presented here. The reference section at Liaselv (Dam \& Surlyk 1998, plate 2) was measured only $5 \mathrm{~km}$ SW of the type section on the southern slope of the Gule Horn mountain and shows the detailed sedimentological features of the formation in the area of the type section.

Reference sections. Neill Klinter, Harris Fjeld (Fig. 14), Nathorst Fjeld, Lepidopteriselv, Liaselv, Ranunkeldal and Horsedal (Fig. 2a). See under individual members.

Thickness. 75-185 m, increasing towards the basin centre.

Lithology. Heteroliths and cross-bedded sandstones.

Fossils. Rare bivalves and belemnites, spores and pollen, diverse trace fossils.

Depositional environment. Marine wave and storm-dominated shoreface, tidal channel, subtidal shoal and offshore transition zone.

Boundaries. Along the southeastern margin of the basin, the lower boundary is a drowning surface separating fossiliferous shoreface sandstones and conglomerates of the Rævekløft Formation below from offshore transition mudstones and heteroliths of the Gule Horn Formation. In the central, northern and western parts of Jameson Land, the boundary is placed where black lacustrine mudstones of the Kap Stewart Group are overlain by well-sorted fossiliferous siltstones and sandstones of 


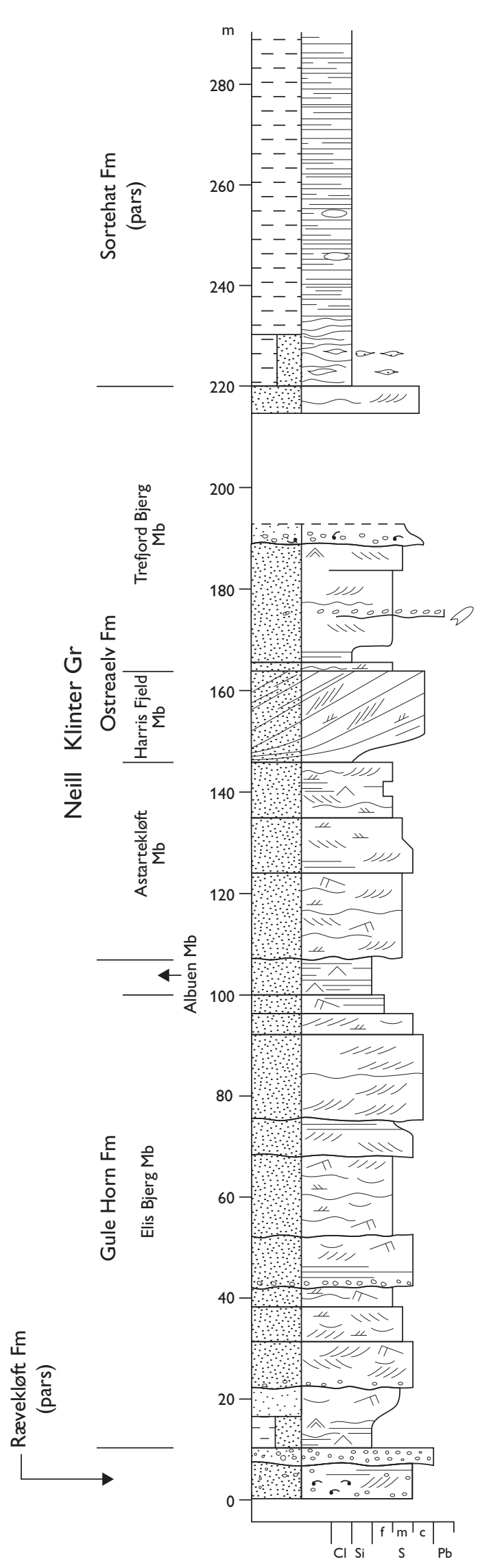

Fig. 14 Reference section of the Gule Horn Formation and type section of the Ostreaelv Formation, Harris Fjeld, Jameson Land (Figs 1, 2a, 12). For legend, see Fig. 7. the Gule Horn Formation, reflecting a marine inundation of the basin. In the south-eastern part of the basin, along the coastal cliffs of Neill Klinter, the upper boundary is sharp but non-erosional and placed at the base of storm-dominated shoreface to subtidal sandsheet sandstones of the Ostreaelv Formation. In the central and northern parts of the basin, the upper boundary is placed at the base of the lagoonal coarsening-upward succession of the Ostreaelv Formation (Horsedal Member), overlying cross-laminated and cross-bedded tidal channel and subtidal shoal sandstones of the Gule Horn Formation.

Distribution. Same as the group.

Chronostratigraphy. Not well known. Constrained by ages of underlying and overlying formations. Dinoflagellate cysts suggest the upper Pliensbachian (probably A. margaritatus ammonite zone) to lower Toarcian in south-eastern Jameson Land and ?uppermost Sinemurian - upper Pliensbachian in northern Jameson Land.

Subdivision. The formation is subdivided from below into the Elis Bjerg and Albuen Members.

\section{Elis Bjerg Member \\ History. Erected by Dam \& Surlyk (1998).}

Type section. Elis Bjerg, north of Hurry Inlet, $22^{\circ} 40.7^{\prime} \mathrm{W}$, 7056.9'N (Dam \& Surlyk 1998, plate 2, Elis Bjerg/Dusén Bjerg section, Figs 2a, 15).

Reference sections. Neill Klinter, Harris Fjeld, Lepidopteriselv, Liaselv, Ranunkeldal and Horsedal (Fig. 2a).

Thickness. 90-185 m, increasing towards the basin centre.

Lithology. Heteroliths and cross-bedded sandstones.

Fossils. Same as the formation.

Depositional environment. Marine wave and storm-dominated shoreface, tidal channel, subtidal shoal and offshore transition zone.

Boundaries. The lower boundary is the same as for the formation (see above). Along the coastal cliffs of Neill Klinter, in the south-eastern part of Jameson Land, the upper boundary is placed at the base of alternating mudstones and well-sorted fine-grained storm-dominated shoreface deposits with massive debris flow deposits of the Albuen Member. In the northern part of the basin, 
it is placed at the base of the lowest thin coarseningupwards unit of wave- and storm-dominated lagoonal sandstone heteroliths rich in rootlet horizons and occasional thin coal beds of the Horsedal Member.
Distribution. Same as the formation.

Chronostratigraphy. Same as the formation.
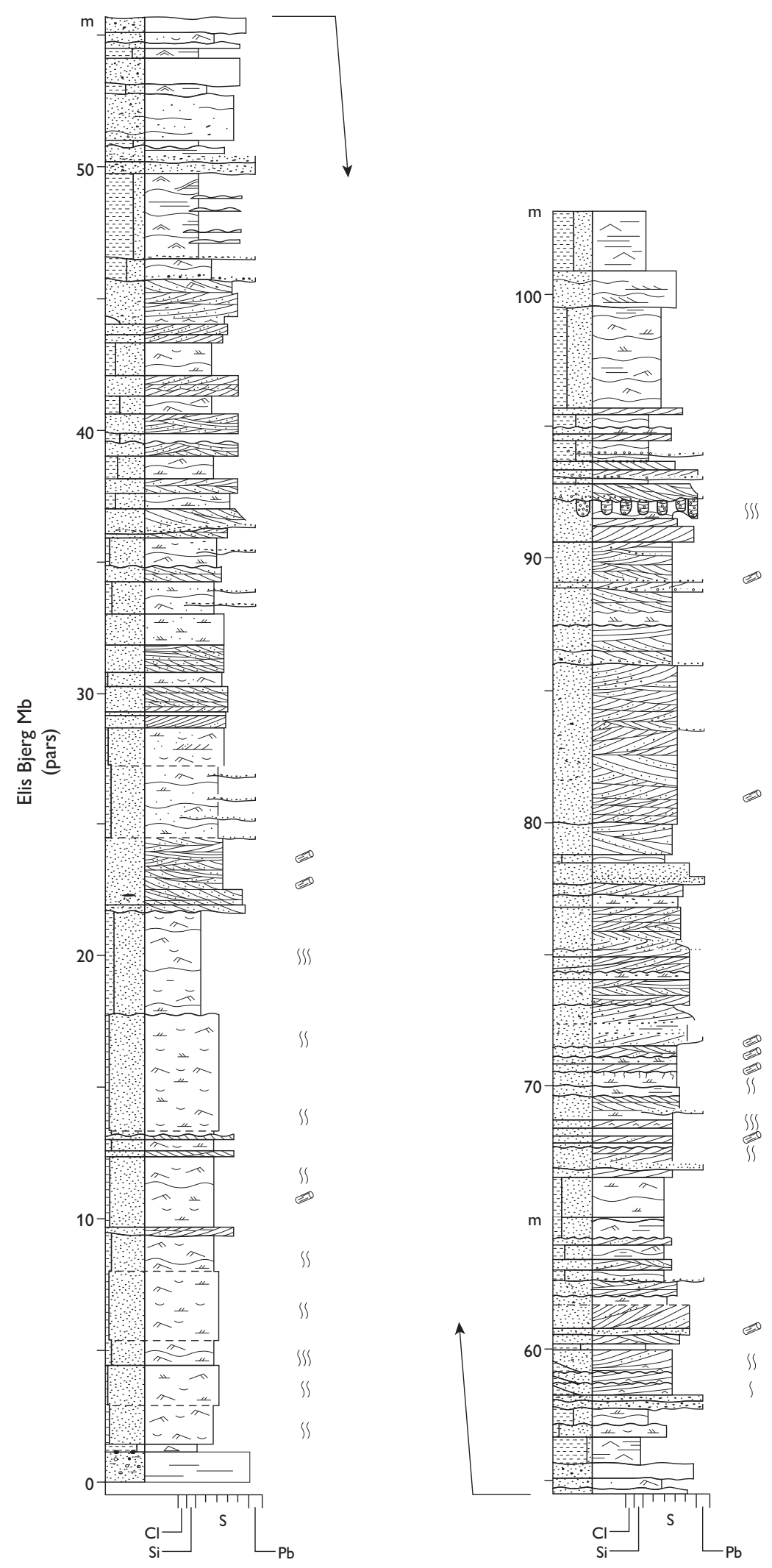

Fig. 15 Type section of the Elis Bjerg Member. Elis Bjerg (Dusén Bjerg), Jameson Land (Figs 1, 2a). From Dam \& Surlyk (1998, plate 2). For legend, see Fig. 7. 


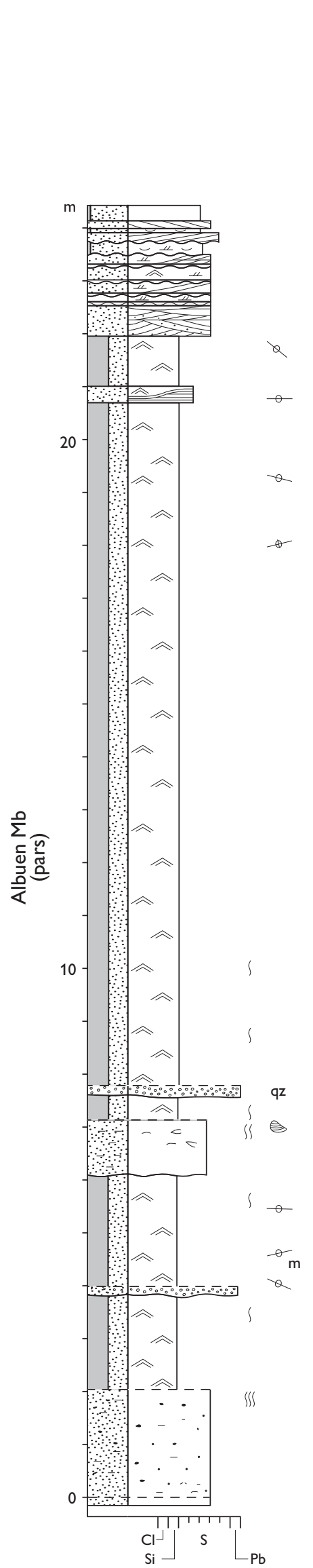

Fig. 16 Type section of the Albuen Member, Albuen, Jameson Land (Figs 1, 2a). From Dam \& Surlyk (1998, fig. 20). For legend, see Fig. 7.

\section{Albuen Member \\ History. Erected by Dam \& Surlyk (1998).}

Type section. Albuen, Hurry Inlet, $70^{\circ} 34.1^{\prime} \mathrm{N}, 22^{\circ} 37.8^{\prime} \mathrm{W}$, (Dam \& Surlyk 1998, fig. 20; Figs 2a, 16).

Reference sections. Qupaulakajik (Greenlandic name for Albuen), Goniomyakløft, Astartekløft, Moskusoksekløft and Harris Fjeld (Fig. 2a).

Thickness. From less than $1 \mathrm{~m}$ up to $26 \mathrm{~m}$.

Lithology. Alternating mudstones and fine-grained, massive and muddy, commonly pebbly sandstones; sandstones with granite boulders are common.

Fossils. Bivalves, belemnites and trace fossils.

Depositional environment. Marine offshore transition zone influenced by storms and the influx of debris flows.

Boundaries. The lower boundary is placed where crossbedded sandstones and heterolithic deposits of the uppermost Elis Bjerg Member are overlain by muddy deposits at a sharp, non-erosional boundary. The upper boundary is placed at the base of the lowest cross-bedded tidal channel and subtidal sand-sheet deposits of the Astartekløft Member. The boundary is sharp and in places erosional along the cliffs of Neill Klinter and farther northwards at Nathorst Fjeld and Elis Bjerg.

Distribution. South-eastern Jameson Land. Wedges out towards the north.

Chronostratigraphy. Upper Pliensbachian, based on palynomorphs.

\section{Ostreaelv Formation}

History. Erected as a member by Surlyk et al. (1973), revised and elevated to formation rank by Dam \& Surlyk (1998).

Type section. The original type section in the Ostreaelv valley (Surlyk et al. 1973, fig. 12) was poorly chosen; the formation is best represented by the excellent exposures at Harris Fjeld, southern Jameson Land, $70^{\circ} 43.4^{\prime} \mathrm{N}$ $22^{\circ} 41.0^{\prime} \mathrm{W}$, which is here designated as a new type section, replacing that at Ostreaelv (Figs 2a, 12, 14).

Reference sections. Qupaulakajik (Greenlandic name for Albuen), Harris Fjeld, Nathorst Fjeld, Lepidopteriselv and Horsedal (Fig. 2a). See under individual members.

Thickness. 112-155 m. 
Lithology. Highly variable, dominated by fine to very coarse-grained, commonly cross-bedded sandstones with mud-draped foresets. Body fossils common in contrast to the underlying Gule Horn Formation.
Fossils. Bivalves, ammonites, belemnites, brachiopods, crinoids, fish scales and trace fossils.

Depositional environment. Marine. Tidal channel, lagoon, terminal lobe, subtidal shoal, shoreface and offshore transition zone.
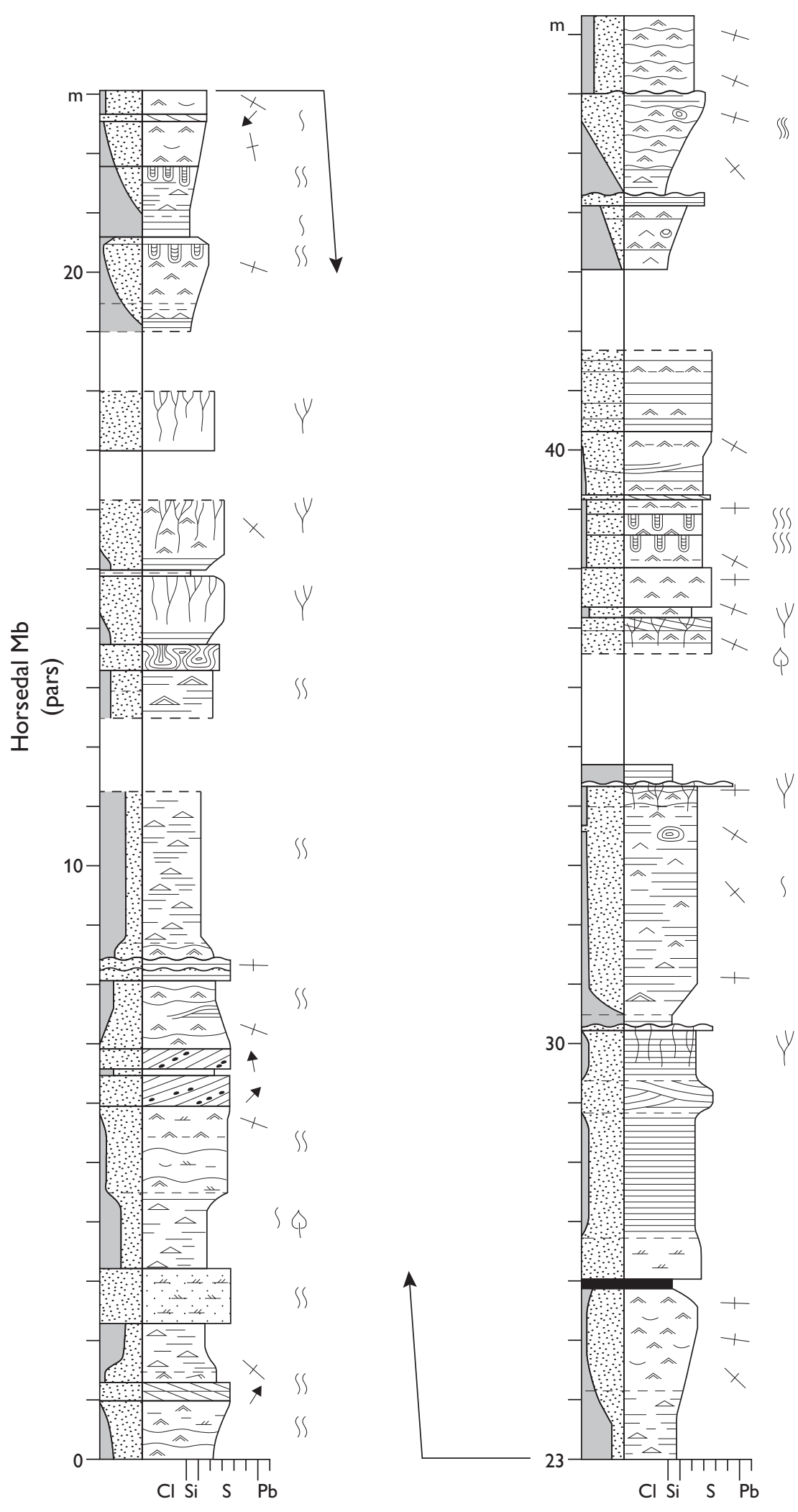

Fig. 17 Type section of the Horsedal Member, Horsedal, Jameson Land (Figs 1, 2a). From Dam \& Surlyk (1998, fig. 24(I), section D). For legend, see Fig. 7. 
Boundaries. Along the coastal cliffs of Neill Klinter, the lower boundary is sharp and placed at the base of tidal channel and subtidal shoal cross-bedded sandstones of the Astartekløft Member, overlying alternating shoreface sandstones and mudstones of the Albuen Member. In the northern and central parts of the basin the lower boundary is placed at the base of wave ripple cross-laminated, parallel-laminated and hummocky cross-stratified sandstones arranged in coarsening-upward units of the Horsedal Member, overlying cross-laminated and cross-bedded sandstones of the Elis Bjerg Member. The upper boundary is placed at the base of the lowest dark mudstone of the Sortehat Formation, overlying sandstones of the Trefjord Bjerg Member. It is flat, very sharp and in places pebble strewn, and is interpreted as a coalesced sequence boundary and transgressive surface of erosion.

Distribution. Same as the group.

Chronostratigraphy. Uppermost Pliensbachian - lowermost Aalenian based on ammonites, belemnites and dinoflagellate cysts.

Subdivision. The formation is subdivided into the Horsedal, Astartekløft, Lepidopteriselv, Nathorst Fjeld, Harris Fjeld, Skævdal and Trefjord Bjerg Members.

\section{Horsedal Member}

History. Erected by Dam \& Surlyk (1998).

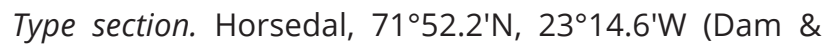
Surlyk 1998, fig. 24, section D; Figs 2a, 17).

Reference section. Cliffs north-west of Rhætelv, north-central Jameson Land (Figs 1, 2a).

\section{Thickness. 50-58 m.}

Lithology. Thin coarsening-upward successions of sandstreaked mudstone passing into medium-grained sandstone, commonly capped by rootlet horizons and coaly beds.

Fossils. Plants, fish scales and marine trace fossils.

Depositional environment. Marine. Wave-dominated beaches and bayhead deltas prograding into a laterally extensive lagoon.

Boundaries. In the northern part of Jameson Land, the lower boundary of the Horsedal Member is placed at the base of the lowermost thin coarsening-upwards unit of sandy heterolithic wave- and storm-dominated lagoonal deposits rich in rootlet horizons and occasional thin coals, overlying cross-bedded sandstones of the Elis Bjerg Member. The upper boundary is erosional and placed at the base of cross-bedded or hummocky cross-stratified and bioturbated shoreface sandstones of the Lepidopteriselv Member, representing a marine drowning of the Horsedal Member lagoon.

Distribution. Northern Jameson Land (Figs 1, 2a).

Chronostratigraphy. Probably upper Pliensbachian, constrained by the ages of underlying and overlying members.

\section{Astartekløft Member}

History. Erected by Dam \& Surlyk (1998).

Type section. Astartekløft, Hurry Inlet, $70^{\circ} 36.9^{\prime} \mathrm{N}$, 2240.4'W (Dam \& Surlyk 1998, fig. 27; Figs 2a, 18).

Reference sections. Nathorst Fjeld, Harris Fjeld, Moskusoksekløft, Goniomyakløft, Albuen and Qupaulakajik (Fig. 2a).

Thickness. 18-43 m.

Lithology. Cross-laminated and cross-bedded sandstones, alternating with thin mudstones.

Fossils. Belemnites, oysters, crinoids and trace fossils.

Depositional environment. Marine. Tidal channels and subtidal shoals.

Boundaries. The lower boundary is placed at the base of the lowest cross-bedded tidal channel and sub-tidal sheet sandstones of the Astartekøft Member, overlying the muddy shoreface deposits of the Albuen Member. The boundary is sharp and in places erosional in the south-eastern part of the basin. The upper boundary is a sharp marine drowning surface and is placed at the base of the lowest silty mudstones of the correlative Nathorst Fjeld and Harris Fjeld Members. At Nathorst Fjeld, a thin extraformational lag conglomerate rests on the basal erosion surface, interpereted as a marine transgressive surface of erosion.

Distribution. South-eastern Jameson Land (Figs 1, 2a).

Chronostratigraphy. Dinoflagellate cysts from the base of the member suggest the lower Toarcian. 


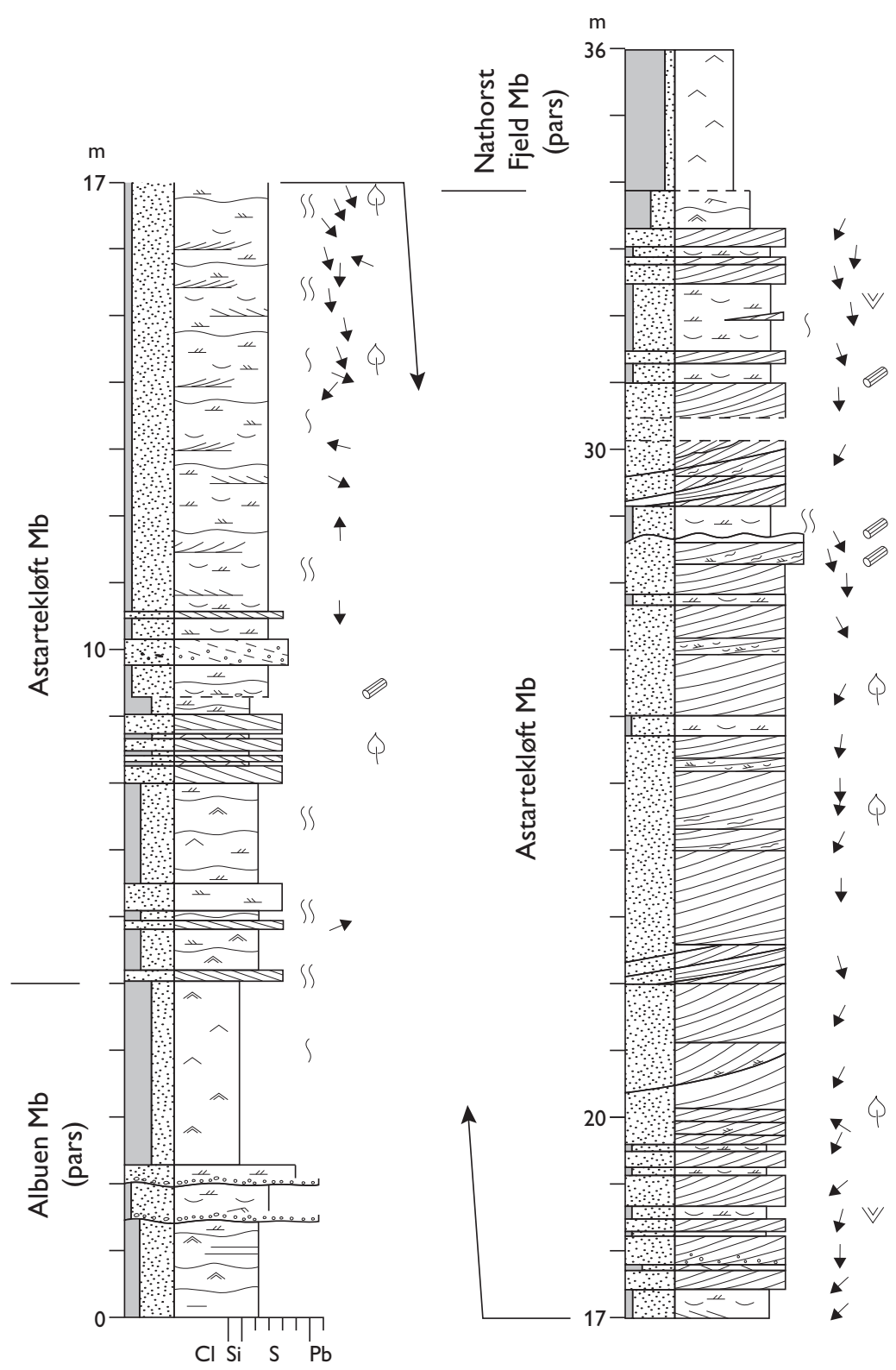

Fig. 18 Type section of the Astartekløft Member, Astartekløft, Jameson Land (Figs 1, 2a). From Dam \& Surlyk (1998, fig. 27). For legend, see Fig. 7.

\section{Lepidopteriselv Member}

History. Erected by Dam \& Surlyk (1998).

Type section. Lepidopteriselv on the south slope of

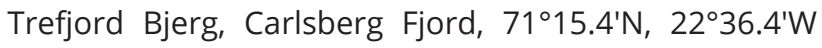
(Dam \& Surlyk 1998, fig. 30; Figs 2a, 19).

Reference sections. Liaselv, Horsedal and Ranunkeldal (Fig. 2a).

\section{Thickness. 48-60 m.}

Lithology. Cross-bedded and hummocky cross-stratified sandstones.

Fossils. Bivalves, belemnites, ammonites, crinoids, dinoflagellate cysts and trace fossils.
Depositional environment. Marine. Tidal channels and wave and storm-dominated shoreface.

Boundaries. At the type locality and at Horsedal, sandstones of the Lepidopteriselv Member rest with a sharp, erosional lower boundary on heterolithic deposits of the Astartekløft and Horsedal Member, respectively. The upper boundary is sharp and placed at the base of muddy bioturbated sandstones of the Skævdal Member, overlying sandstones of the Lepidopteriselv Member.

Distribution. Northern Jameson Land (Figs 1, 2a).

Chronostratigraphy. Lower Toarcian, D. tenuicostatum ammonite zone, D. semicelatum subzone, based on ammonites. 


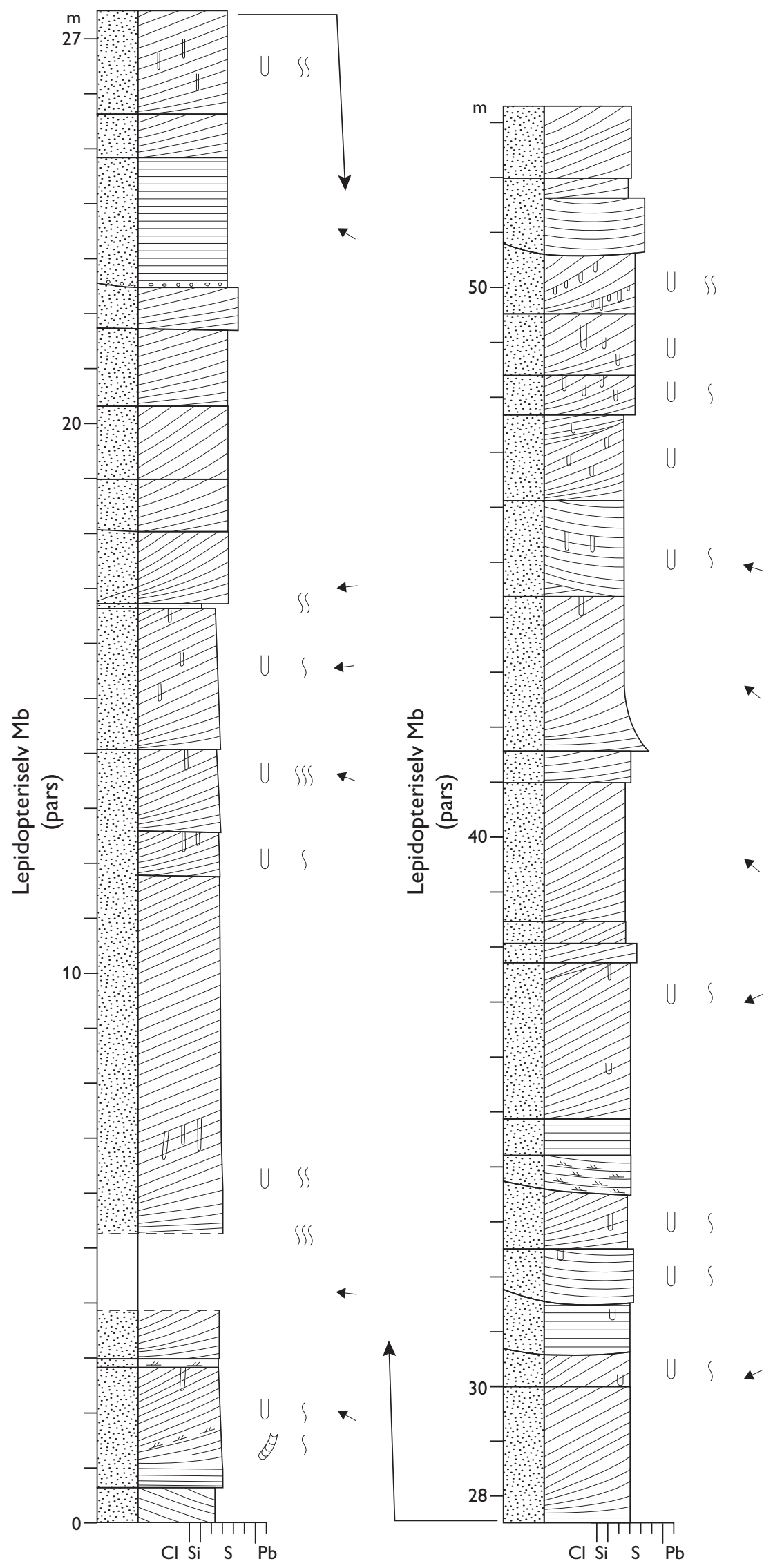

Fig. 19 Type section of the Lepidopteris Elv Member, Lepidopteriselv, Jameson Land (Figs 1, 2a). From Dam \& Surlyk (1998, fig. 30). For legend, see Fig. 7. 

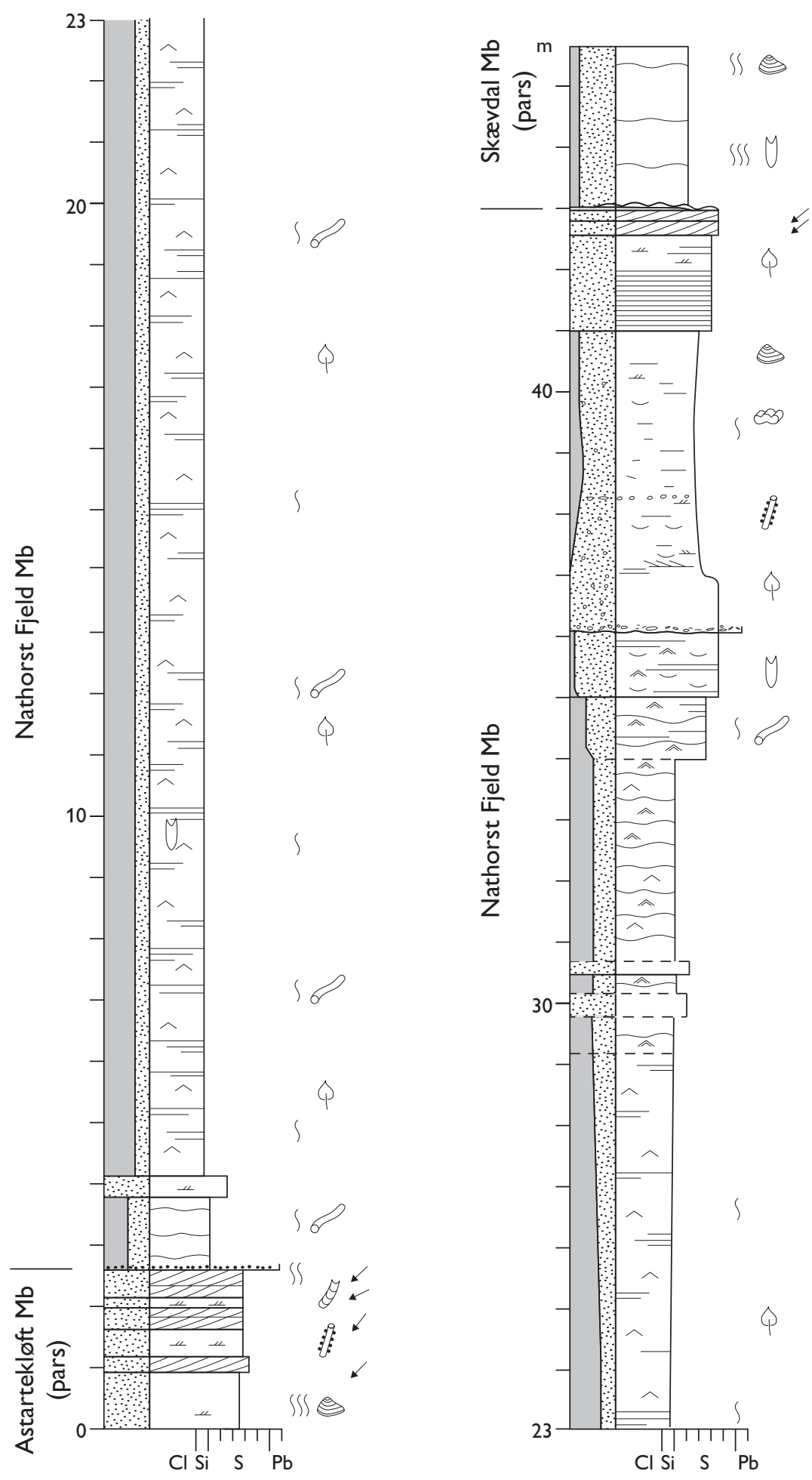

Fig. 20 Type section of the Nathorst Fjeld Member, Nathorst Fjeld, Jameson Land (Figs 1, 2a). From Dam \& Surlyk (1998, fig. 32). For legend, see Fig. 7.

Nathorst Fjeld Member

History. Erected by Dam \& Surlyk (1998).

Thickness. 29-37 m.

Type section. Nathorst Fjeld, $70^{\circ} 49.1^{\prime} \mathrm{N}, 22^{\circ} 39.5^{\prime} \mathrm{W}$ (Dam

Lithology. A coarsening-upward succession of alterna\& Surlyk 1998, fig. 32; Figs 2a, 20). ting silty mudstones and laminae/beds of fine-grained wave-ripple cross-laminated and hummocky crossReference sections. Moskusoksekløft, Astartekløft and stratified sandstone, sharply overlain by cross-bedded, Albuen (Fig. 2a). 
bioturbated fossiliferous coarse-grained sandstones and mudstone-clast conglomerates.

Fossils. Bivalves, ammonites, belemnites, brachiopods, crinoids, vertebrates and trace fossils.

Depositional environment. Marine offshore transition zone to shoreface.

Boundaries. The lower boundary to the sandstones of the Astartekløft Member is placed at the base of silty offshore mudstones of the Nathorst Fjeld Member at a sharp marine drowning surface. At Nathorst Fjeld, a thin extraformational lag conglomerate rests on the boundary, interpreted as a marine transgressive surface of erosion. The upper boundary is placed at the base of the lowest strongly bioturbated shelf sandstones of the Skævdal Member, overlying shoreface sandstones of the Nathorst Fjeld Member at a drowning surface.

Distribution. South-eastern Jameson Land (Figs 1, 2a).

Chronostratigraphy. The belemnite Parapassolotheuthis polita suggests the lower Toarcian, uppermost $H$. falciferum or lowermost $H$. bifrons ammonite zone (D. commune subzone), while the ammonite Dactylioceras sp. suggests the lower Toarcian, $D$. tenuicostatum ammonite zone, D. semicelatum subzone (see discussion in Dam \& Surlyk 1998). Palynomorphs suggest the lower Toarcian.

\section{Harris Fjeld Member}

History. Erected by Dam \& Surlyk (1998).

Type section. Harris Fjeld, Hurry Inlet, $70^{\circ} 43.6^{\prime} \mathrm{N}$, $22^{\circ} 41.2^{\prime} W$ (Figs 2a, 21). Dam \& Surlyk (1998) did not specify which of their four sections at Harris Fjeld was the type section; section IV of Dam \& Surlyk (1998, fig. $34)$ is herein designated the type section.

\section{Thickness. 34-40 m.}

Lithology. Stacked, tabular low-angle, heterolithic clinoform beds, up to $18 \mathrm{~m}$ thick, which pass laterally into cross-bedded sandstones or silty mudstones.

Fossils. Scarce bivalves, belemnites and trace fossils.

Depositional environment. Marine. Ebb-tidal deltas.

Boundaries. The lower boundary is placed at the base of the lowest thin coarsening-upward clinoform bed of the terminal lobe complex of the Harris Fjeld Member, representing a marine drowning surface. The upper

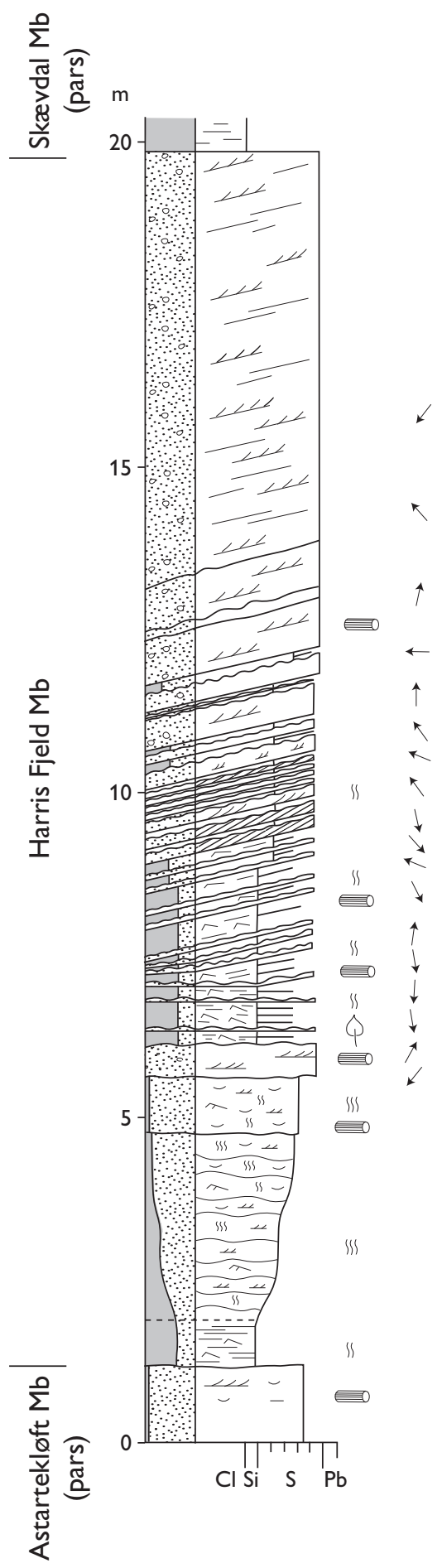

Fig. 21 Type section of the Harris Fjeld Member, Harris Fjeld, Jameson Land (Figs 1, 2a). From Dam \& Surlyk (1998, fig. 34, section IV). For legend, see Fig. 7.

boundary is sharp and placed at the base of the lowest mudstones of the overlying Skævdal Member; this surface is interpreted as a marine transgressive surface of erosion.

Distribution. Harris Fjeld area only (Figs 2a, 12). 


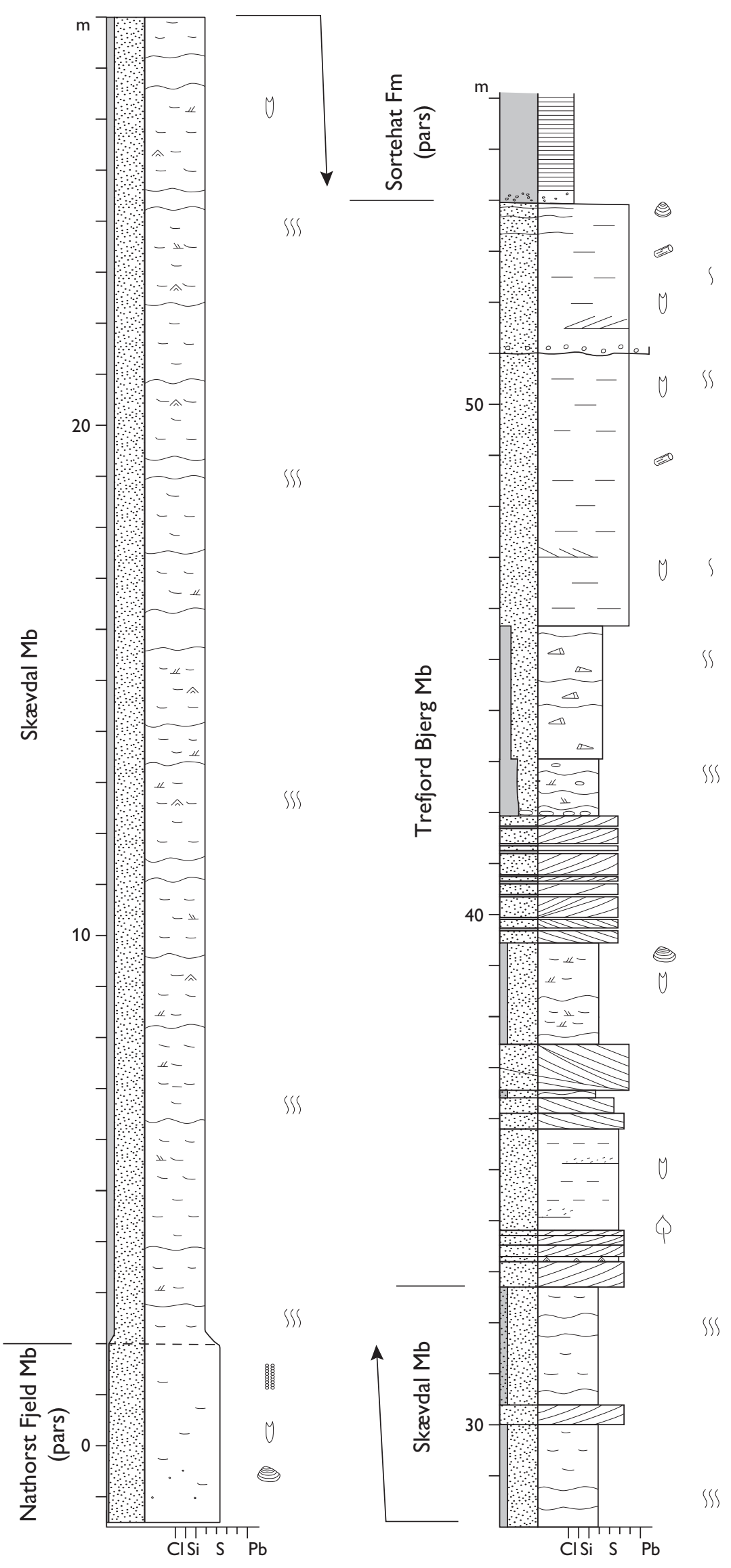

Fig. 22 Type section of the Skævdal Member, Skævdal, Albuen, Jameson Land (Figs 1, 2a). From Dam \& Surlyk (1998, fig. 38). For legend, see Fig. 7. 
Chronostratigraphy. The member is considered as timeequivalent to the Nathorst Fjeld and Lepidopteriselv Members, suggesting the lower Toarcian.

\section{Skaevdal Member}

History. Erected by Dam \& Surlyk (1998).

Type section. Skævdal at Albuen, Hurry Inlet, $70^{\circ} 35.0^{\prime} \mathrm{N}$, $22^{\circ} 38.0^{\prime} \mathrm{W}$ (Figs 2a, 22).
Reference sections. Nathorst Fjeld, Lepidopteriselv and Horsedal (Fig. 2a).

Thickness. 12-40 m.

Lithology. Bioturbated fossiliferous sandy mudstones and muddy fine-grained sandstones, locally cross-bedded, hummocky cross-stratified or wave rippled.

Fossils. Ammonites, belemnites, bivalves, brachiopods, dinoflagellate cysts and trace fossils.

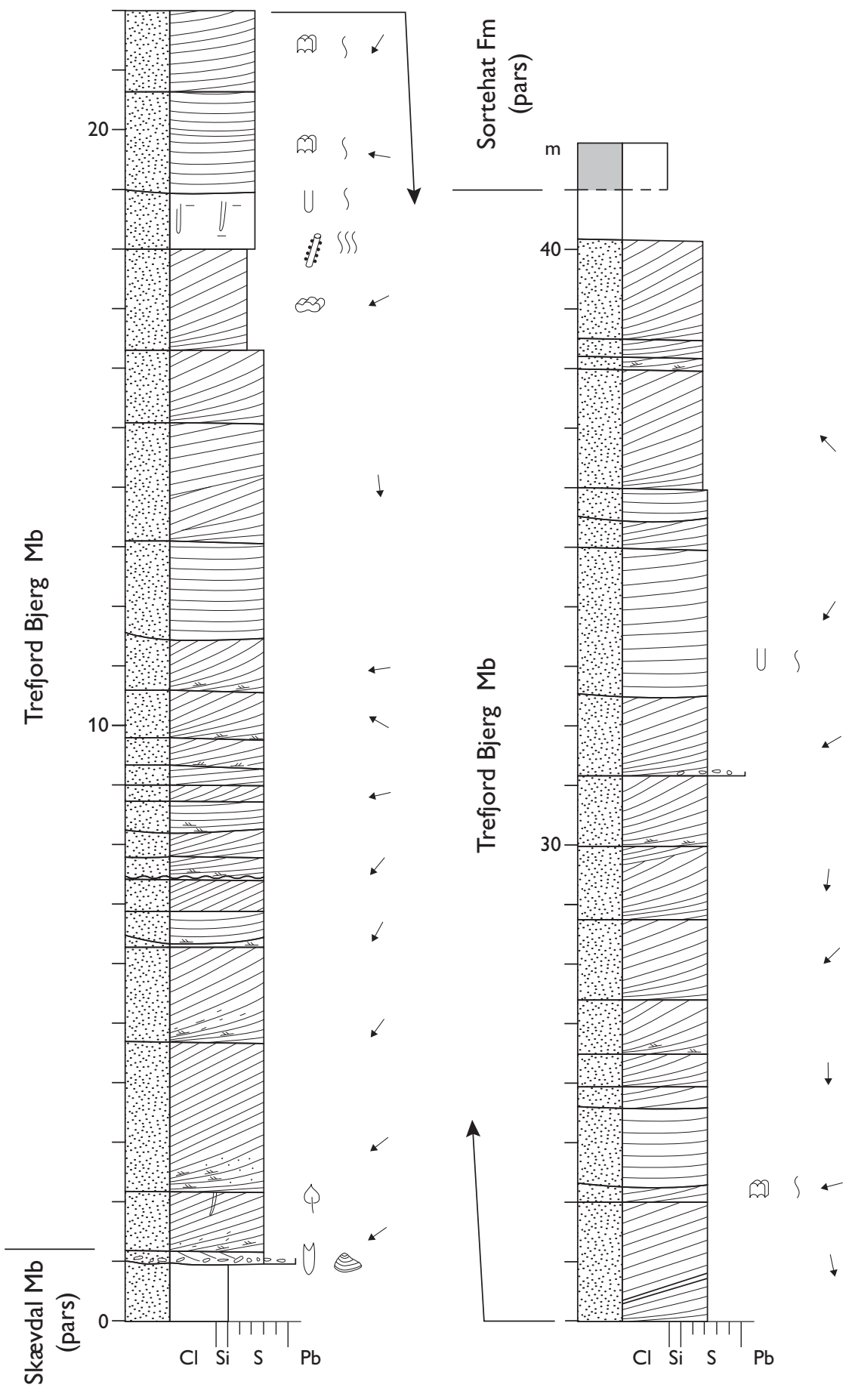

Fig. 23 Type section of the Trefjord Bjerg Member, Lepidopteriselv, Trefjord Bjerg, Jameson Land (Figs 1, 2a). From Dam \& Surlyk (1998, fig. 38). For legend, see Fig. 7. 
Depositional environment. Marine. Offshore transition zone and lower shoreface.

Boundaries. The lower boundary is sharp, in places erosional, and is placed at the base of the lowermost muddy sandstones and sandy mudstones, overlying sandstones of the Nathorst Fjeld, Harris Fjeld and Lepidopteriselv Members. The boundary is a transgressive surface of erosion. The upper boundary is placed at the base of the lowest tidal channel sandstones of the Trefjord Bjerg Member. It is a sharp erosional unconformity at Lepidopteriselv and Horsedal and sharp, but non-erosional along the coastal cliff of Neill Klinter (see Fig. 24), and represents a sequence boundary.

\section{Distribution. Same as group.}

Chronostratigraphy. Dating is ambiguous and in need of further work as the precise localisation of recovered macrofossils is uncertain. The belemnite 'Parabrachybelus' subaduncatus suggests the uppermost Toarcian, D. levesquei ammonite zone, the ammonite Dactylioceras sp. indicates the lower Toarcian D. tenuicostatum ammonite zone, D. semicelatum subzone, and palynomorphs suggest the upper Toarcian - lower Aalenian.

\section{Trefjord Bjerg Member}

History. Erected by Dam \& Surlyk (1998).

Type section. Lepidopteriselv, at the south slope of Trefjord Bjerg, $71^{\circ} 15.2^{\prime} \mathrm{N}, 2^{\circ} 36.8^{\prime} \mathrm{W}$ (Figs 2a, 23).

Reference sections. Albuen (Fig. 22), Harris Fjeld, Nathorst Fjeld, Ostreaelv and Horsedal (Fig. 2a).

\section{Thickness. 21-45 m.}

Lithology. Cross-bedded sandstones, in places with claydraped foresets, hummocky cross-stratified sandstones, and sandy bioturbated mudstones (Fig. 24).

Fossils. Bivalves, belemnites, ammonites and trace fossils.

Depositional environment. Marine. Tidal channel, subtidal shoals, and wave- and storm-dominated shoreface.

Boundaries. At Ostreaelv, Trefjord Bjerg and Horsedal, the lower boundary is sharp, erosional and is an important sequence boundary. It is placed at the base of the lowest coarse-grained sandstone of the Trefjord Bjerg Member, overlying muddy sandstone of the Skævdal

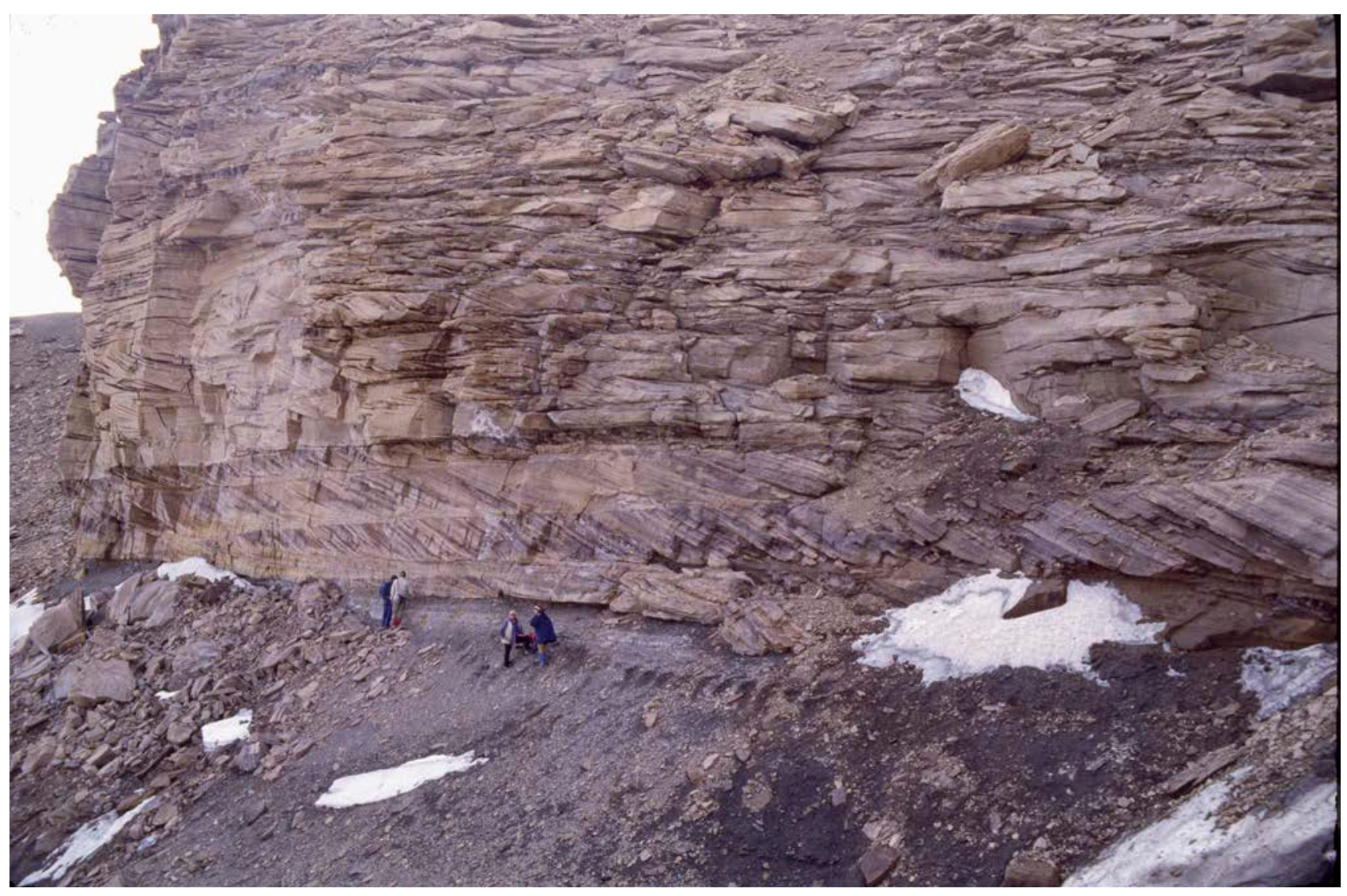

Fig. 24 Boundary between the dark fine-grained Skævdal Member and the large-scale cross-bedded sandstone of the Trefjord Bjerg Member, both members of the Ostreaelv Formation. Trefjord Bjerg, Jameson Land (Figs 1, 2a). Persons for scale at the boundary. 


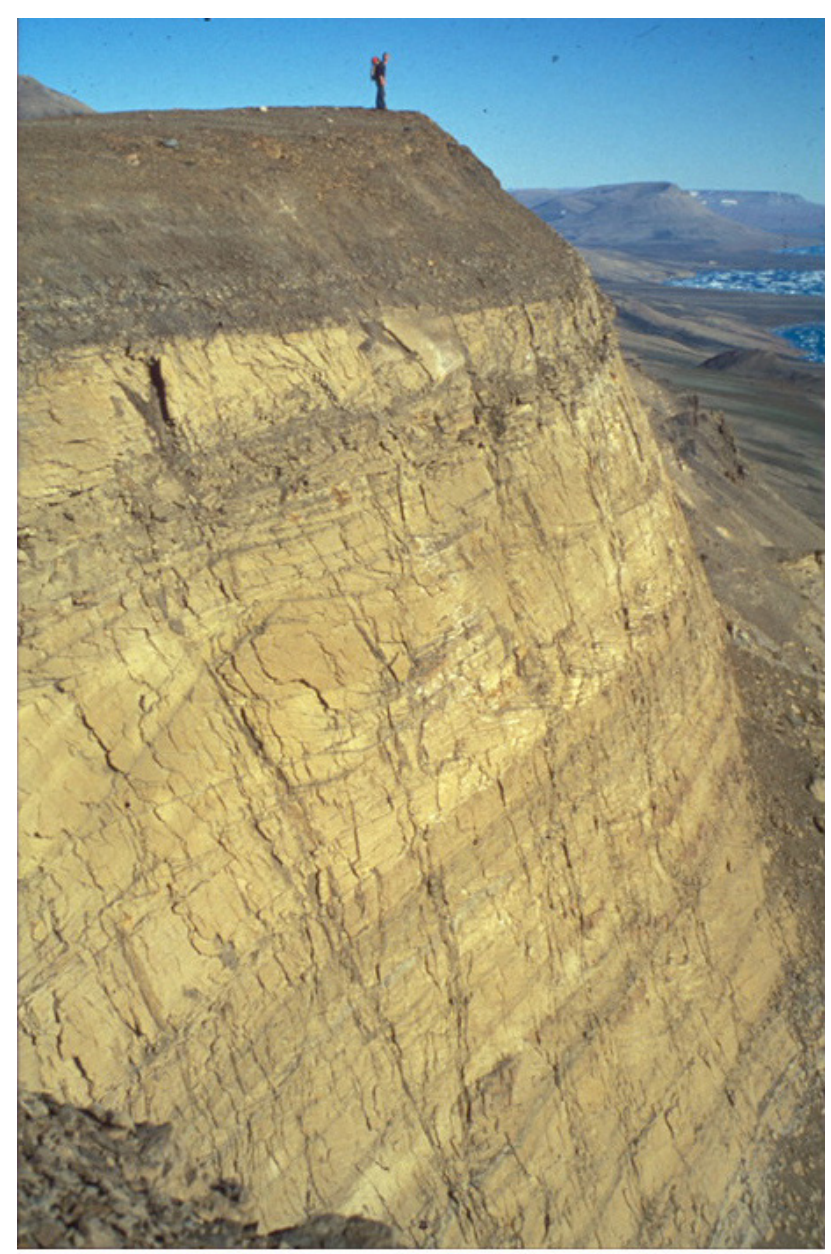

Fig. 25 Boundary between large-scale cross-bedded sandstones of the Trefjord Bjerg Member and dark mudstones of the Sortehat Formation. Person for scale. Immediately north of Astartekløft, Neill Klinter, south-east Jameson Land (Figs 1, 2a).

Member (Fig. 24). The boundary is draped by a lag of bored sideritic clasts, extra-formational pebbles, logs and belemnites, interpreted as channel lags. Along Neill Klinter, the boundary to the underlying Skævdal Member is sharp and non-erosional. The upper boundary to the overlying Sortehat Formation is one of the most conspicuous lithological boundaries in the Jurassic succession. It is placed at the base of black mudstones of the Sortehat Formation, overlying sandstones of the Trefjord Bjerg Member (Fig. 25). It is flat, very sharp and in places pebble strewn, and represents a coalesced sequence boundary and transgressive surface of erosion.

Distribution. Same as group.

Chronostratigraphy. Upper Toarcian - lowermost Aalenian, based on dinoflagellate cysts.

\section{Sortehat Formation}

History. Erected by Surlyk et al. (1973) as the lowermost member of the Vardekløft Formation. Elevated to formation rank by Surlyk (1990a, b), and excluded from the Vardekløft Formation by Surlyk (1991). Included in the Neill Klinter Group by Dam \& Surlyk (1998).

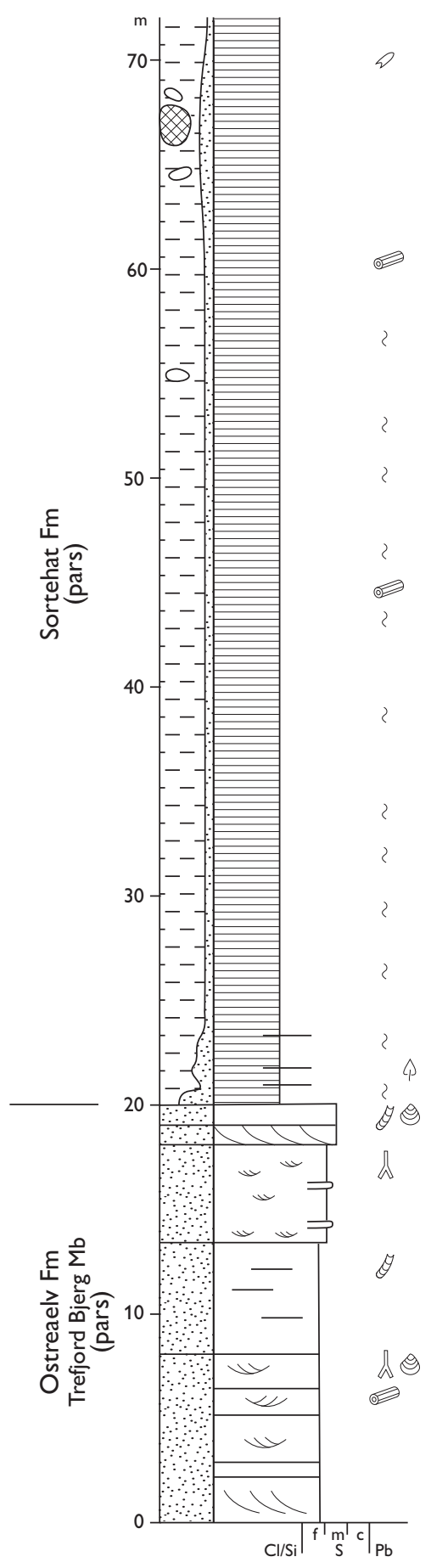

Fig. 26 Log of a cored section of the Sortehat Formation at the type locality, Sortehat, Jameson Land (Figs 1, 2a). This slimline core (GGU 303143) is accessible for study at the Geological Survey of Denmark and Greenland. For legend, see Fig. 7. 


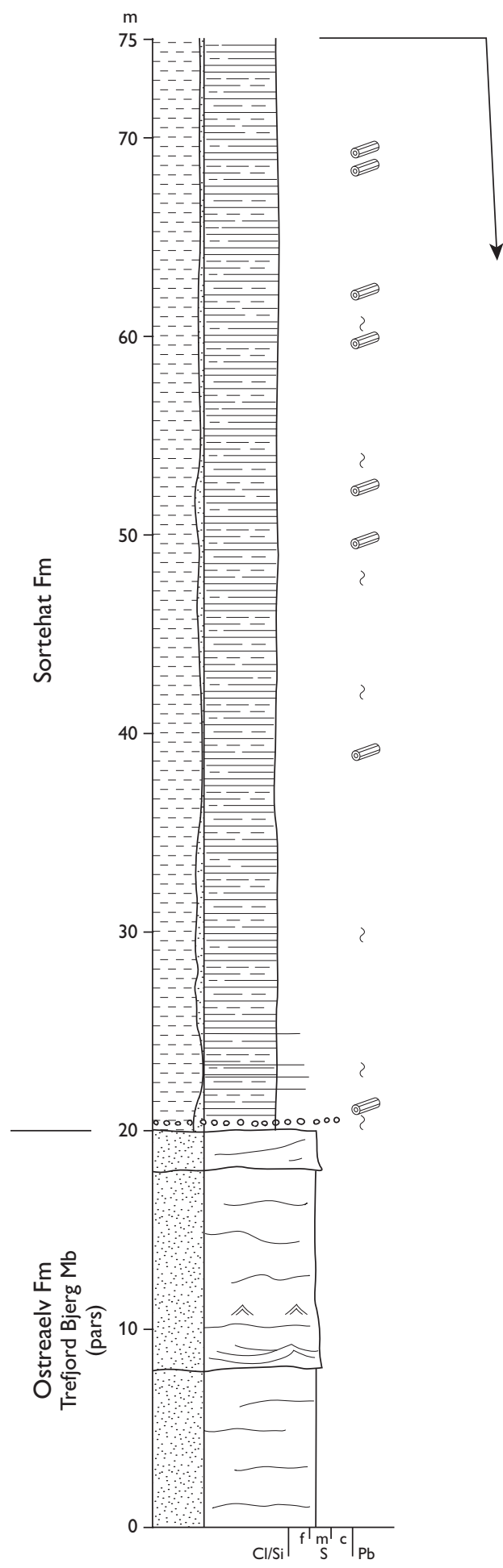

Type section. Sortehat, Ugleelv, southern Jameson Land, $22^{\circ} 50.3^{\prime} \mathrm{W}, 70^{\circ} 53.8^{\prime} \mathrm{N}$ (Fig. 2a).

Reference sections. Sortehat (Fig. 26; a slimline core, drilled at the type locality in 1993, is available for study at the Geological Survey of Denmark and Greenland), Albuen, Goniomyakløft, Trefjord Bjerg, Liaselv (Fig. 27), Pelion, Coloradodal, Pingeldal (Fig. 2a).
Fig. 27 Reference section of the Sortehat Formation, Liaselv, Jameson Land (Figs 1, 2a). For legend, see Fig. 7.

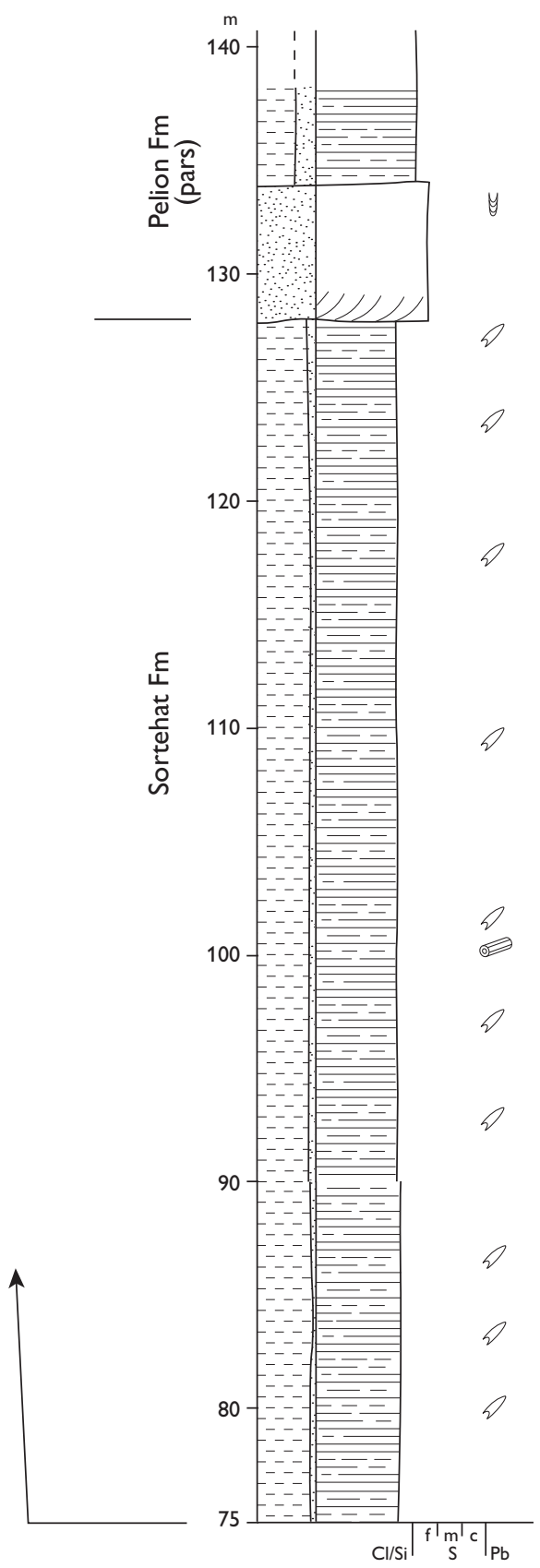

Thickness. 60-120 m.

Lithology. Dark grey to black mudstones with ironstone concretions, passing upwards into silty mudstones with layers of fine-grained sandstone.

Fossils. Bivalves (oysters), saurian vertebrates, macroplants, belemnites in the upper part, trace fossils, spores, pollen, and dinoflagellate cysts. 
Depositional environment. Marine offshore, lower part poorly oxygenated and deposited under brackish marine conditions.

Boundaries. The lower boundary between the sandstones of the Trefjord Bjerg Member and the black mudstones of the Sortehat Formation is flat, very sharp, in places pebble strewn and represents a coalesced sequence boundary and transgressive surface of erosion. The upper boundary is placed at the base of cross-bedded marine sandstones of the Pelion Formation (Vardekløft Group), overlying black mudstones of the Sortehat Formation. In south-eastern Jameson Land, the upper boundary is in some cases developed as a sharp erosional surface separating black mudstones of the Sortehat Formation from a thin greyish silty mudstone bed with ammonites and marine trace fossils that rapidly passes upwards into yellow cross-bedded sandstones, both facies belonging to the Pelion Formation.

Distribution. Same as the group.

Chronostratigraphy. Aalenian - lower Bajocian, based on dinoflagellate cysts.

\section{Vardekløft Group}

revised unit

History. Introduced as a formation by Rosenkrantz (1929); revised, described and subdivided into the Sortehat, Pelion and Fossilbjerget Members by Surlyk et al. (1973), who also gave a historical account. The Sortehat Member was excluded from the formation by Surlyk (1991) and included as a formation in the Neill Klinter Group by Dam \& Surlyk (1998). The Vardekløft Formation is here elevated to group rank and revised to include the Bristol Elv, Bastians Dal, Muslingebjerg, Pelion, Fossilbjerget, Payer Dal, Jakobsstigen, Olympen, Hareelv, Bernbjerg, Raukelv and Hesteelv Formations.

Type area. Jameson Land.

Thickness. The group forms the top unit in most areas of its distribution, so the maximum original thickness is not well known, but probably up to about $650 \mathrm{~m}$.

Lithology. Conglomerates and pebbly sandstones with subordinate coals dominate the Bastians Dal and Bristol Elv Formations, coals characterise the Muslingebjerg Formation, sandstones dominate the Pelion, Jakobsstigen, Olympen, Payer Dal and Raukelv Formations, whereas the Fossilbjerget, Bernbjerg, Hareelv and Hesteelv Formations predominantly comprise silty mudstones.
Fossils. Ammonites, bivalves, belemnites, brachiopods, crinoids, plant fragments, dinoflagellate cysts and trace fossils.

Depositional environment. The group comprises fully marine shoreface to offshore deposits in Jameson Land (Pelion, Fossilbjerget and Olympen Formations). Farther north, it is fluvial at the base (Bristol Elv and Bastians Dal Formations), succeeded by coastal swamp, floodplain and shallow marine sediments (Muslingebjerg Formation) that in turn are overlain by dominantly marine shoreface and offshore shelf deposits (Pelion, Payer Dal, Jakobsstigen, Olympen, Hareelv, Bernbjerg, Raukelv and Hesteelv Formations).

Boundaries. The lower boundary is placed at the base of marine or fluvial sandstones, sharply overlying black mudstones of the Sortehat Formation in Jameson Land, continental Upper Triassic redbeds and sandstones on Traill $\varnothing$ and Geographical Society $\varnothing$, Lower Triassic sandstones and mudstones on Hold with Hope, Upper Permian carbonates in southern Wollaston Forland, and crystalline basement rocks in northern Wollaston Forland, Kuhn $\varnothing$, Hochstetter Forland, Store Koldewey and Germania Land. The group shows marked onlap onto progressively older rocks from south to north. It forms the top stratum in southern Jameson Land, and is overlain by Lower Cretaceous mudstones and sandstones on Traill $\varnothing$, Geographical Society $\varnothing$, Hold with Hope, Clavering $\varnothing$, Wollaston Forland, Kuhn $\varnothing$ and Hochstetter Forland. Details on boundaries are given under the component formations.

Distribution. From the southern tip of Jameson Land in the south to Germania Land in the north (Fig. 1).

Chronostratigraphy. Bajocian-Ryazanian, based on rich ammonite faunas and dinoflagellate cyst assemblages.

Subdivision. The group is subdivided (from below) into the Bristol Elv, Bastians Dal, Muslingebjerg, Pelion, Fossilbjerget, Payer Dal, Jakobsstigen, Olympen, Hareelv, Bernbjerg, Raukelv and Hesteelv Formations.

\section{Bristol Elv Formation}

History. The formation was erected by Therkelsen \& Surlyk (2004). The deposits of the formation were independently recognised and briefly described by Stemmerik et al. (1997) and Price \& Whitham (1997) who included them in their PM1 unit.

Type section. Southern Svinhufvud Bjerge, Traill $\varnothing$, $72^{\circ} 23.1^{\prime} \mathrm{N}, 23^{\circ} 23.9^{\prime} \mathrm{W}$ (Figs 1, 2c, 28, 29). 


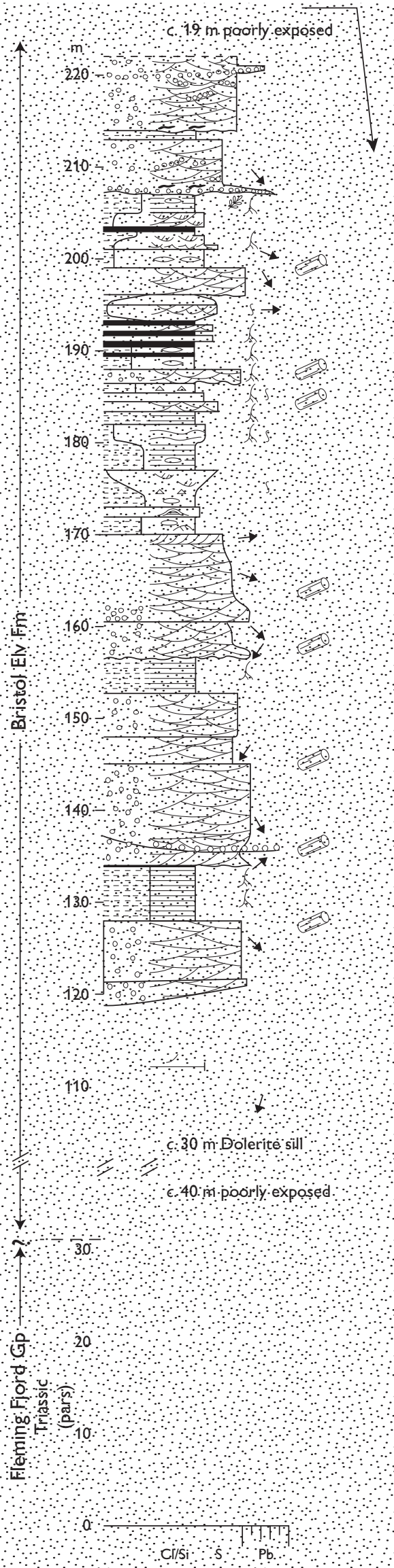

Fig. 28 Type section of the Bristol Elv Formation, southern Svinhufvud Bjerge, Traill $\varnothing$ (Figs 1, 2c). From Therkelsen \& Surlyk (2004, fig. 3). For legend, see Fig. 7.

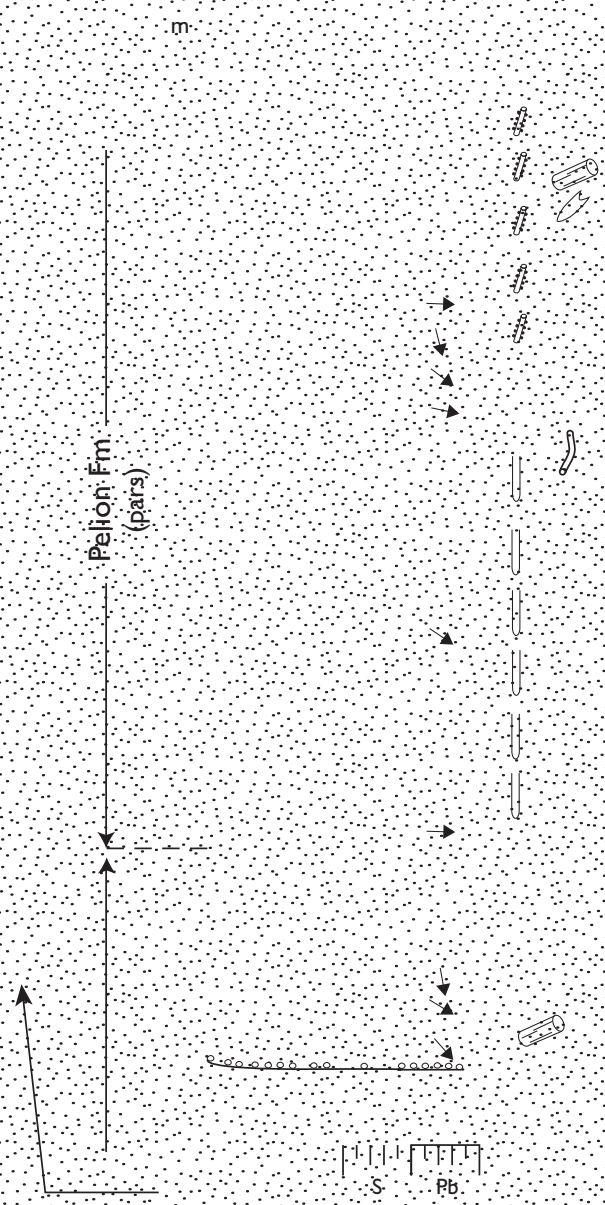




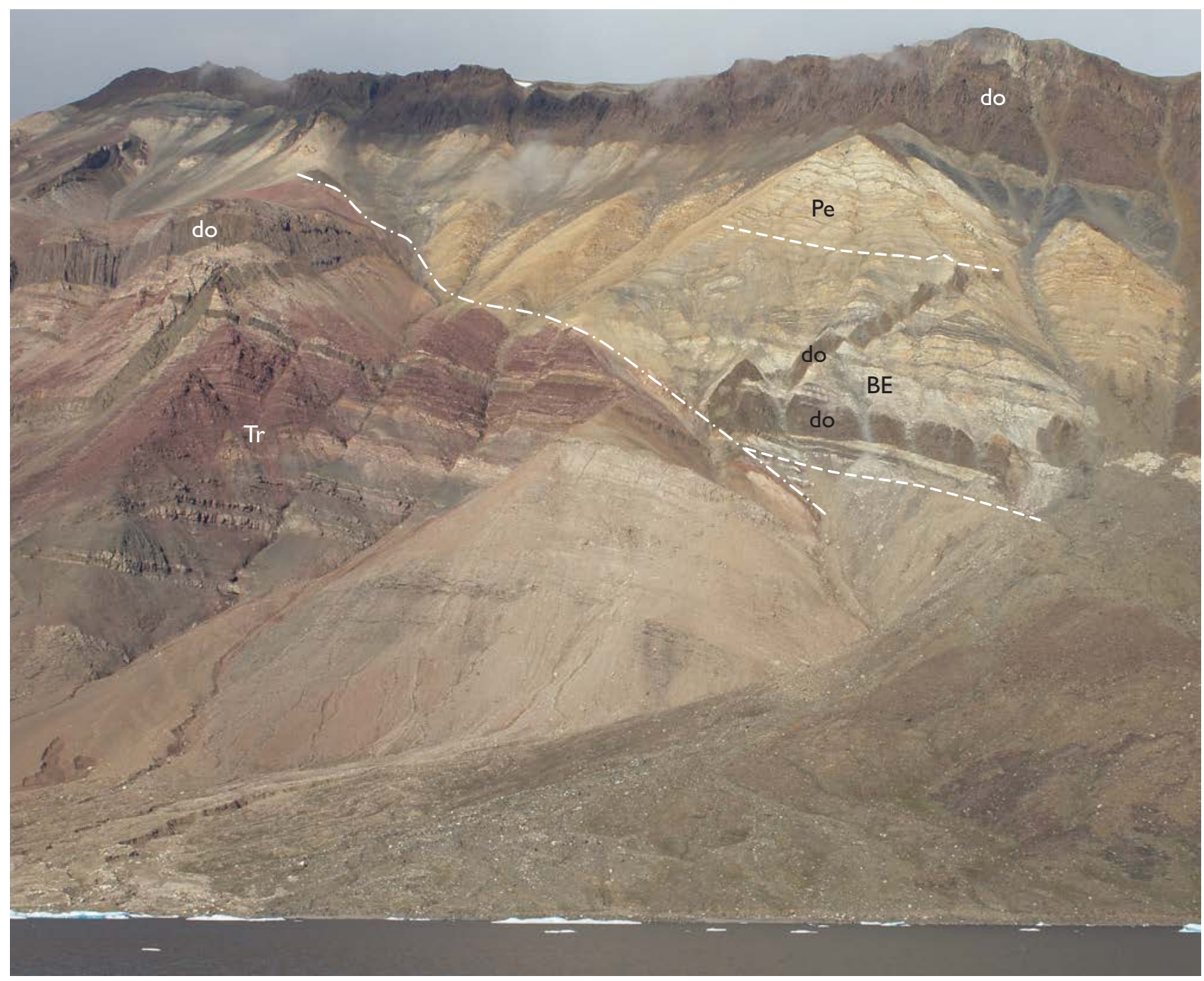

Fig. 29 Photograph of the type section of the Bristol Elv Formation (BE), overlain by the Pelion Formation (Pe), downfaulted against Triassic redbeds (Tr), and intruded by dark Palaeogene dolerite sills and dykes (do), southern Svinhufvud Bjerge, Traill $\varnothing$ (Figs 1, 2c). The sill at the base of the formation is about $30 \mathrm{~m}$ thick.

Reference section. North-eastern Svinhufvud Bjerge, southern Mols Bjerge (Fig. 2c).

\section{Thickness. 80-155 m.}

Lithology. Cross-bedded pebble conglomerates and pebbly sandstones intercalated with thin, dark grey mudstones and centimetre-thick coal beds with rootlets.

Fossils. Rare plants and palynomorphs.

Depositional environment. Braided river, floodplain, peat swamp and lake.

Boundaries. The lower boundary is placed at the base of the lowest yellow sandstone or conglomerate overlying red Upper Triassic mudstones and coarse-grained sandstones. The upper boundary is placed at the base of the lowermost marine sandstone with trace fossils referred to the Pelion Formation, and represents a marine flooding surface.

Distribution. Svinhufvud Bjerge, Mols Bjerge and probably also Vælddal on Traill $\varnothing$ (Fig. 2c).

Chronostratigraphy. Uncertain, probably ?lower Bajocian, constrained by ammonites of the immediately overlying Pelion Formation, long-ranging palynomorphs and regional considerations.

Key reference. Therkelsen \& Surlyk (2004). 


\section{Bastians Dal Formation}

History. Erected by Alsgaard et al. (2003).

Type section. Bastian Dal, Kuhn $\varnothing, 74^{\circ} 53.9^{\prime} \mathrm{N}, 20^{\circ} 20.6^{\prime} \mathrm{W}$

(Alsgaard et al. 2003, fig. 11; Figs 1, 2e, 30).

Thickness. Up to about $140 \mathrm{~m}$.

Lithology. Fining-upward units of cobble and pebble conglomerate, passing upwards into parallel-laminated and trough cross-bedded micaceous sandstone (Fig. 31). High content of carbonaceous material and thin coal beds ( $<30 \mathrm{~cm}$ thick) occur locally.

Fossils. Spores and pollen.

Depositional environment. Braided and low sinuosity rivers.

Boundaries. Overlies crystalline basement rocks, partly as infill of a valley incised into the basement. The upper boundary is placed at the base of the lowest thick coal bed referred to the Muslingebjerg Formation, or by marine cross-bedded sandstones of the Pelion Formation, or by marine sandstones of the Payer Dal Formation on Hochstetter Forland.

Distribution. Central, and locally southern, Kuhn $\varnothing$, Store Koldewey (Figs 1, 2d, 2e).

Chronostratigraphy. ?Bathonian (palynomorphs indicate a general Middle Jurassic age); the formation is overlain by upper Bathonian sandstones of the Pelion Formation.

Key reference. Alsgaard et al. (2003).
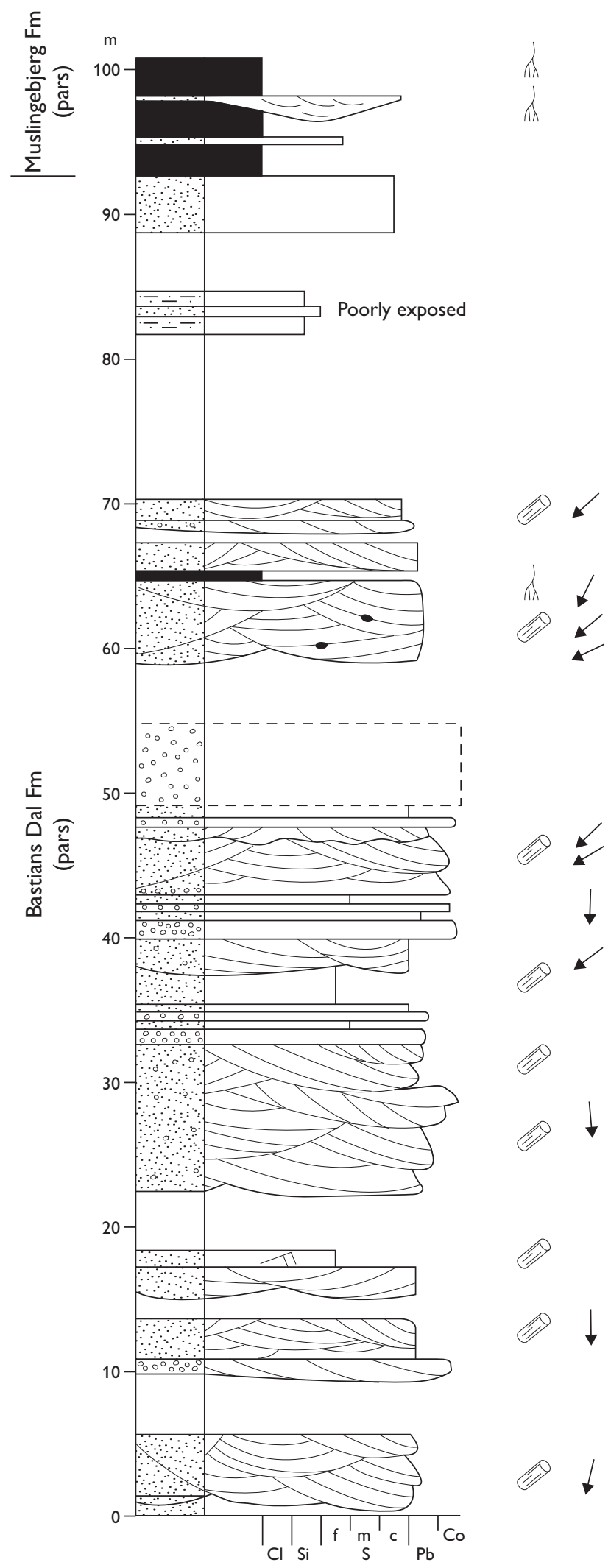

Fig. 30 Type section of the Bastians Dal Formation, east side of Bastian Dal, Kuhn $\varnothing$ (Figs 1, 2e). For legend, see Fig. 7. 


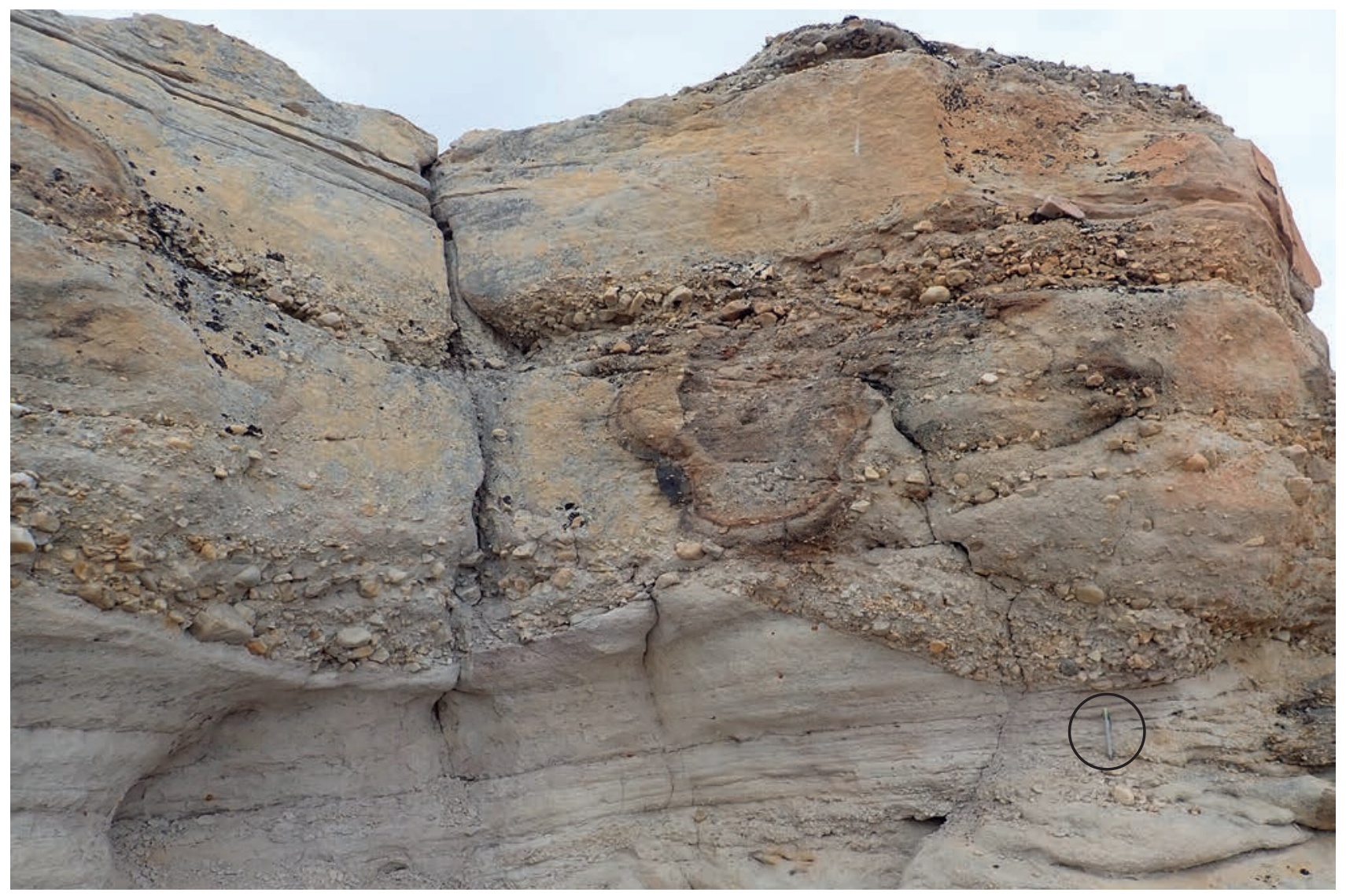

Fig. 31 Fluvial conglomerates and sandstones, Bastians Dal, Formation, Bastian Dal, Kuhn Ø (Figs 1, 2e). Pencil (encircled) for scale.

\section{Muslingebjerg Formation revised unit}

History. Erected as a member by Surlyk (1977a). Here elevated to formation rank.

Type section. Kulhus, Hochstetter Forland, $75^{\circ} 11.5^{\prime} \mathrm{N}$, $19^{\circ} 59.5^{\prime}$ W (Surlyk 1977a, fig. 22; Figs 2e, 32, 33).

Reference sections. Bastian Dal on Kuhn Ø (Fig. 2e), Kulhøj in Germania Land (Fig. 1).

Thickness. Up to about $50 \mathrm{~m}$ in central Kuhn $\varnothing$ (S.D. Andrews \& H. Vosgerau, unpublished data 2018).

Lithology. Coal beds, up to about $5 \mathrm{~m}$ thick, alternating with siltstones, horizontally bedded and cross-bedded sandstones; rootlet beds common.

Fossils. Plant fragments, log imprints, thin oyster bed.

Depositional environment. Coastal mires, floodplain, fluvial channels, lagoon and marine shoreface.
Boundaries. The lower boundary is not exposed in the type section. Elsewhere, it is defined at the base of the lowest thick coal bed overlying crystalline basement rocks, or at the base of the lowest metre-thick coal bed overlying fluvial conglomerates and sandstones of the Bastians Dal Formation. On Kuhn $\varnothing$, the upper boundary is placed at the base of marine sandstones with trace fossils of the Pelion or Payer Dal Formations, whereas on Store Koldewey the upper boundary is placed at the base of dark marine mudstones of the Niesen Member (Lindemans Bugt Formation).

Distribution. Central Kuhn $\varnothing$, south-western Hochstetter Forland, Store Koldewey and Germania Land (Figs 1, 2d, 2e).

Chronostratigraphy. Upper(?) Bathonian - middle Callovian. Strata immediately overlying the highest coal bed on Hochstetter Forland contain dinoflagellate cysts suggesting the upper Callovian P. athleta ammonite zone (Piasecki \& Stemmerik 2004).

Key references. Clemmensen \& Surlyk (1976), Surlyk (1977a), Petersen et al. (1998, 2002), Petersen \& Vosgerau (1999), Alsgaard et al. (2003), Bojesen-Koefoed et al. (2012). 


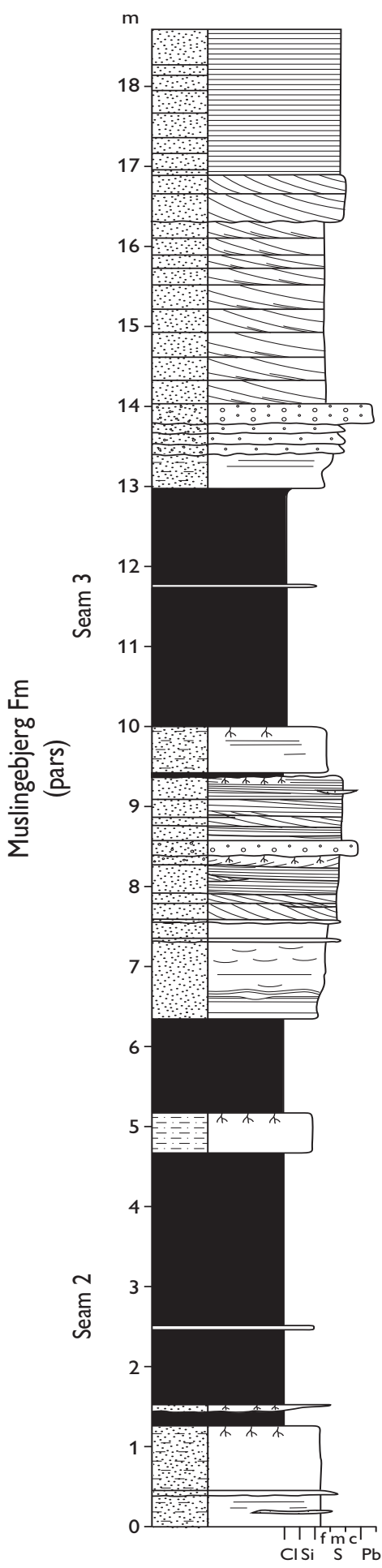

Fig. 32 Type section of the Muslingebjerg Formation, southern Hochstetter Forland (Figs 1, 2e). From Petersen et al. (1998, fig. 2). For legend, see Fig. 7.

\section{Pelion Formation revised unit}

History. Erected as the middle member of the Vardekløft Formation, which originally included the Sortehat, Pelion and Fossilbjerget Members (Surlyk et al. 1973). Here elevated to formation rank.

Type section. North slope of the mountain of Pelion, north-central Jameson Land, $71^{\circ} 28.3^{\prime} \mathrm{N}, \quad 23^{\circ} 18.0^{\prime} \mathrm{W}$ (Surlyk et al. 1973, fig. 17; Figs 1, 2a, 34, 35).

Reference sections. Goniomyakløft (Fig. 42), Zackenberg, Katedralen, Mikael Bjerg, Trefjord Bjerg, Olympen, all in Jameson Land, Svinhufvud Bjerge on Traill $\varnothing$, Cardiocerasdal (see Figs 45, 46) and Hohgant on Wollaston Forland and Payer Dal on Kuhn $\varnothing$ (Figs 1, 2a, 2c, 2e, see Fig. 44).

Thickness. Increases from about $10 \mathrm{~m}$ in south-eastern Jameson Land northwards to $310 \mathrm{~m}$ at the type section and possibly up to $650 \mathrm{~m}$ at Antarctic Havn although this section has not been studied in detail and may include the lower part of the Olympen Formation. At least $240 \mathrm{~m}$ on Traill $\varnothing$, possibly up to a few hundred metres on Wollaston Forland and Kuhn $\varnothing$. In most outcrops, it forms the top of the terrain so only minimum thickness estimates can be given.

Lithology. Cross-bedded, planar bedded or hummocky cross-stratified, medium-grained, micaceous sandstones dominate, with subordinate laminated fine-grained sandstones, coarse-grained and pebbly sandstones.

Fossils. Abundant ammonites in Jameson Land, in addition to belemnites, bivalves, crinoids, brachiopods and trace fossils, notably Tisoa habichi. Note that the latter taxon, which in the East Greenland literature is referred to as Diplocraterion habichi, has been recently revised and is now named Tisoa habichi (Knaust 2019). T. habichi is a highly characteristic trace fossil of this formation but also of other clean shallow marine Jurassic sandstones of East Greenland, especially the Prasino and Fynselv Members (Raukelv Formation) and the Kronen Member (Hartz Fjeld Formation).

Depositional environment. Marine shoreface and shallow shelf.

Boundaries. In Jameson Land, the lower boundary is sharp and placed at the base of the lowest marine sandstone, overlying black mudstones of the Sortehat Formation (for further details, see Sortehat Formation). South of the mountain of Pelion, the floor of an incised valley locally defines the base of the Pelion Formation; the boundary is erosional, and is placed at the base of grey, cross-bedded, medium-grained sandstones rich in coal intraclasts, overlying dark grey, laminated mudstones of the Sortehat Formation. North of Jameson 


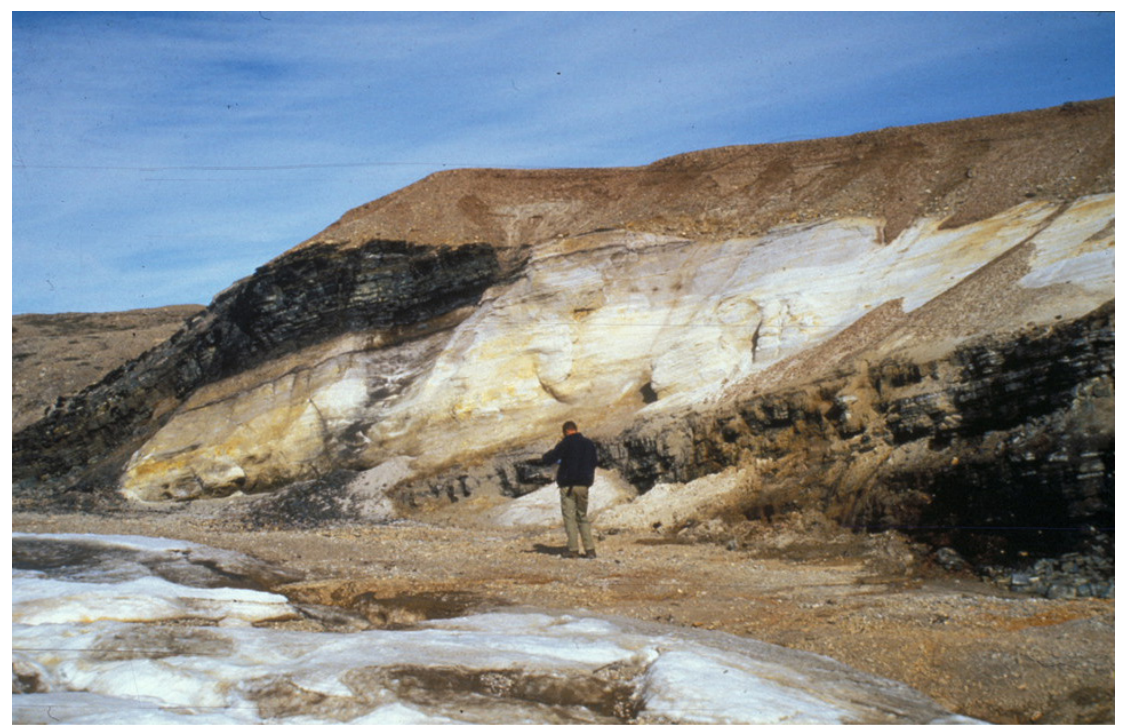

Fig. 33 Type section of the Muslingebjerg Formation, showing light-coloured, shallow marine sandstones sandwiched between thick coal beds, southern Hochstetter Forland (Figs 1, 2e).

Land, the Pelion Formation overlies fluvial pebbly sandstones of the Bristol Elv Formation on Traill $\varnothing$, and fluvial conglomerates and sandstones of the Bastians Dal Formation or coal-bearing sandstones of the Muslingebjerg Formation on Kuhn $\varnothing$. The lower boundary is placed at the base of the lowest yellow marine sandstone overlying Lower Triassic sandstones and mudstones on Hold with Hope, Upper Permian carbonates on southern Wollaston Forland, and crystalline basement rocks in northern Wollaston Forland, Kuhn $\varnothing$ and Store Koldewey. The upper boundary is strongly diachronous, younging from south to north. It is sharp and placed at the base of grey silty mudstones of the Fossilbjerget Formation in Jameson Land and on Traill $\varnothing$, at the base of heteroliths and coaly mudstones of the Jakobsstigen Formation on Wollaston Forland, and beneath sandstones of the Payer Dal Formation on Hold with Hope, northern Wollaston Forland and Kuhn $\varnothing$. In some areas on Traill $\varnothing$ and Store Koldewey, it is overlain with erosional unconformity by Lower - mid-Cretaceous mudstones.

Distribution. Same as the group, with the exception of Germania Land where the Pelion Formation is absent.

Chronostratigraphy. Upper Bajocian - middle Callovian, C. borealis - K. jason ammonite zones (faunal horizons $\mathrm{J}-1$ to J-36 of Callomon 1993), based on ammonites. The uppermost strata are poorly fossiliferous and the age relations to the overlying Olympen, Jakobsstigen, Muslingebjerg and Payer Dal Formations are not always certain. At Jurakløft, northern Wollaston Forland, the upper part of the formation contains dinocysts that suggest a late Callovian age.
Subdivision. The formation includes the Ugleelv, Parnas and Spath Plateau Members.

Key references. Spath (1932), Maync (1947), Donovan (1957), Haller (1971), Surlyk et al. (1973), Surlyk (1977a, 1990a, b, 1991), Surlyk \& Clemmensen (1983), Heinberg \& Birkelund (1984), Callomon (1993, 1994), Surlyk et al. (1993), Engkilde (1994), Engkilde \& Surlyk (1993, 2003), Price \& Whitham (1997; thickness estimates probably overestimated, see Surlyk \& Noe-Nygaard 2001a), Surlyk \& Noe-Nygaard (2000), Alsen \& Surlyk (2004), Vosgerau et al. (2004a, b), Callomon et al. (2015), Bjerager et al. (2020).

\section{Ugleelv Member \\ new member}

History. This new member is defined to describe a variant of the Pelion Formation in south-east Jameson Land. The upper part of the member in the type section is dominated by a prominent high-angle clinoform set that has been figured by Surlyk et al. (1973, fig. 19), Heinberg \& Birkelund (1984, figs 13-14) and Engkilde \& Surlyk (2003, fig. 27).

Name. After the Ugleelv river in south-eastern Jameson Land (Fig. 2a).

Type section. Katedralen, on the southern side of the Ugleelv river valley, $70^{\circ} 53.3^{\prime} \mathrm{N}, 22^{\circ} 52.9^{\prime} \mathrm{W}$ (Figs 2a, 36).

Reference section. Ræveelv (Fig. 2a).

Thickness. 110-170 m. 

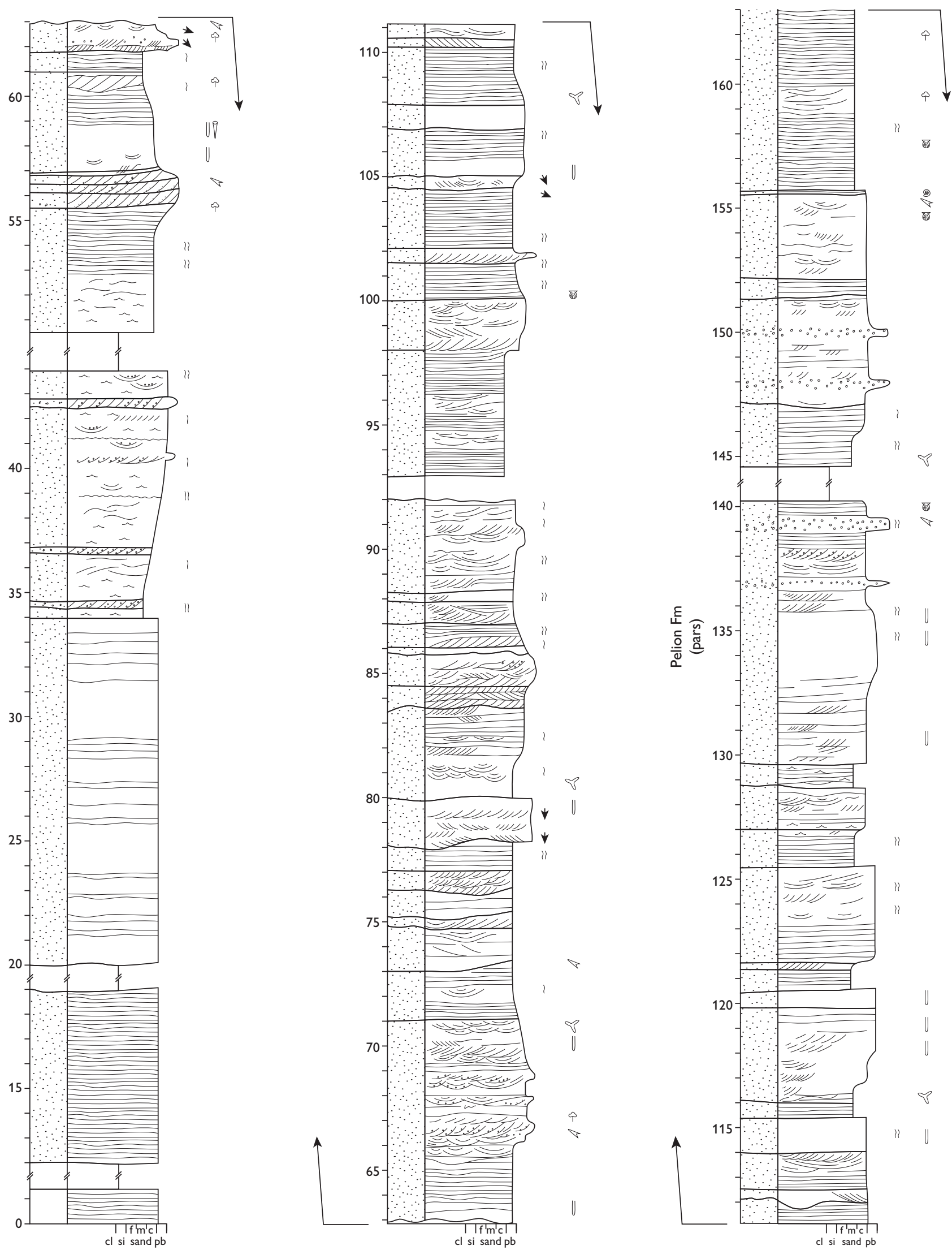

Fig. 34 Type section of the Pelion Formation, Pelion, north-central Jameson Land (Figs 1, 2a). For legend, see Fig. 7. 

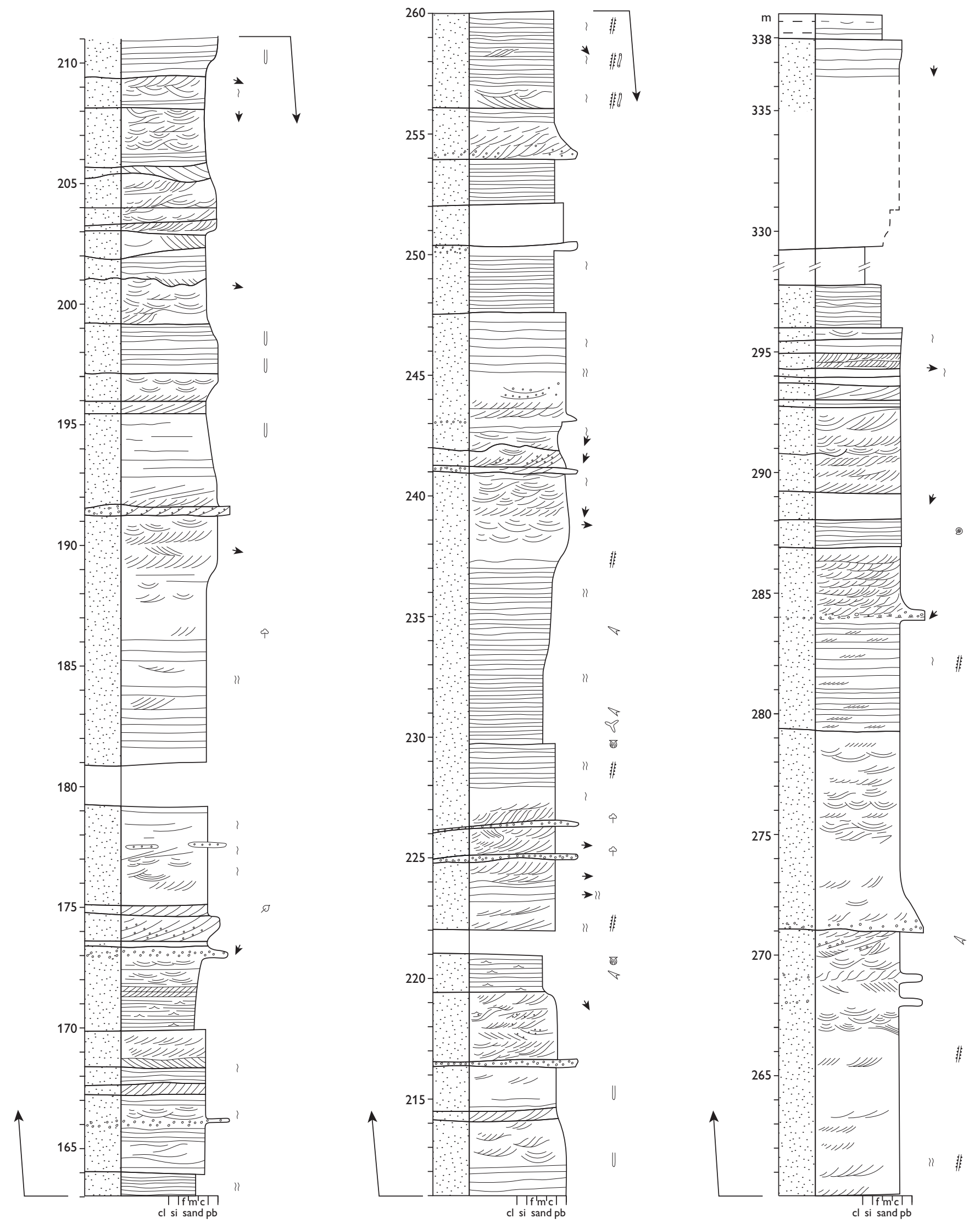

Fig. 34 (continued) Type section of the Pelion Formation, Pelion, north-central Jameson Land (Figs 1, 2a). For legend, see Fig. 7. 


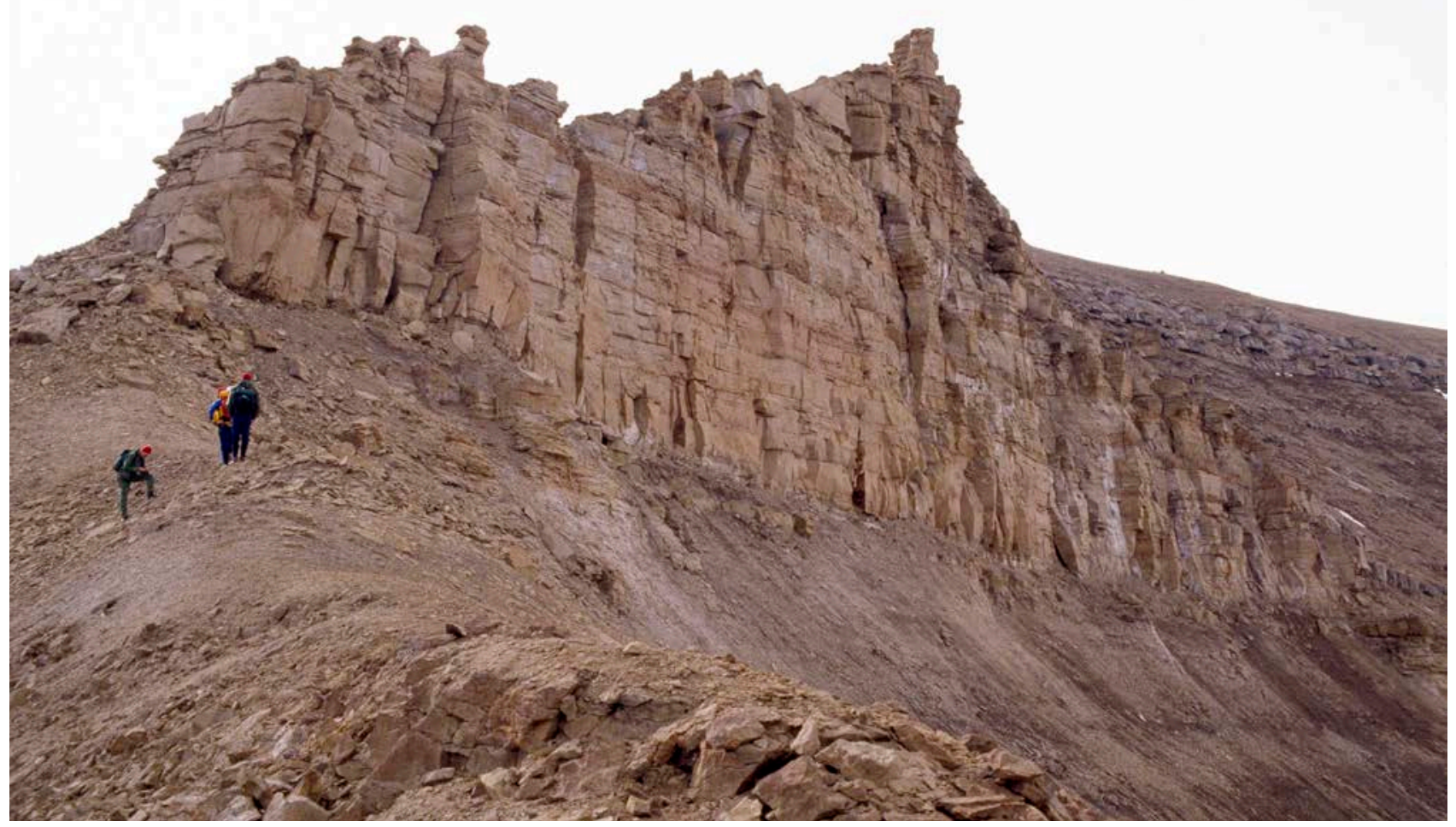

Fig. 35 Type section of the Pelion Formation. Persons for scale. Pelion, central Jameson Land (Figs 1, 2a). The vertical sandstone cliff immediately above the geologists is c. $10 \mathrm{~m}$ high.

Lithology. Characterised by one (at Katedralen) or two (at Ræveelv) prominent, cliff-forming, high-angle clinoform-bedded sandstones, which form the upper part of the member (Fig. 37). The lower part consists of structureless, cross-laminated, cross-bedded and hummocky cross-stratified very fine- to medium-grained sandstones. The middle part of the member in the type section comprises stacked coarsening-upward siltstone-sandstone cycles.

Fossils. Abundant ammonites and belemnites, bivalves, crinoids, brachiopods, rare gastropods, trace fossils and wood fragments. Fossils are commonly concentrated in distinct layers.

Depositional environment. Shallow marine shelf and shoreface. Upper part represents a tidally influenced shelf-margin wedge.

Boundaries. In the type section, the lower boundary is placed at the base of light, silty fine-grained structureless to faintly bedded siltstones and sandstones, overlying a dark, silty, fine-grained, laminated sandstone bed of the mudstone-dominated Sortehat Formation with a sharp, planar contact. The upper boundary is placed where soft reddish-grey, silty, laminated, fossil-rich and bioturbated mudstones of the Fossilbjerget Formation overlie light grey sandstones of the Pelion Formation. This boundary commonly weathers out as a marked ammonite and belemnite-strewn, marine drowning surface (Fig. 37), regionally reflecting a northward retreat of the shoreface environment.

Distribution. The area around inner Ugleelv and Ræveelv, south-eastern Jameson Land (Figs 1, 2a).

Chronostratigraphy. Upper Bajocian, C. borealis - basal C. pompeckji ammonite zones (faunal horizons J-1 to J-4 of Callomon 1993), based on ammonites. The lower sandstone and middle siltstone-sandstone units both belong to the $C$. borealis zone; the upper clinoform-bedded unit belongs to the $C$. indistinctus to $C$. pompeckji zones.

\section{Parnas Member}

new member

History. First recognised as a regressive sandstone wedge in the upper levels of the previous Pelion Member 


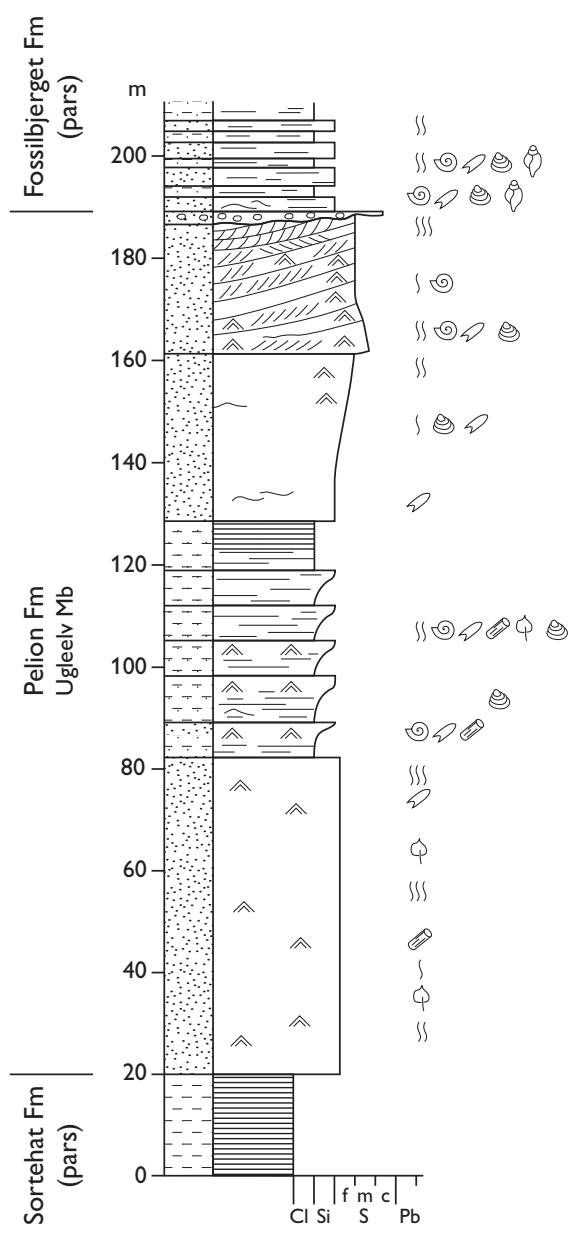

Fig. 36 Type section of the Ugleelv Member, Ugleelv, Jameson Land (Figs 1, 2a). For legend, see Fig. 7. by Heinberg \& Birkelund (1984). Erected here as a new member of the Pelion Formation.

Name. After Parnas in north-central Jameson Land (Fig. 2a).

Type section. North-east slope of the Olympen mountain, $71^{\circ} 27.0^{\prime} \mathrm{N}, 23^{\circ} 28.0^{\prime} \mathrm{W}$ (Figs 2a, 38).

Reference section. Parnas (Fig. 2a).

Thickness. About $30 \mathrm{~m}$.

Lithology. Very fine- to coarse-grained sandstones forming metre- to decimetre-scale coarsening-upward cycles.

Fossils. Abundant ammonites and belemnites, rare bivalves, trace fossils and wood fragments.

Depositional environment. Shallow marine shelf to shoreface.

Boundaries. The member forms a local prograding sandy wedge in the otherwise silty mudstone-dominated Fossilbjerget Formation. The lower boundary is placed at the base of a grey, silty to sandy, coarsening-upward unit, about one metre thick, with hummocky cross stratification in the top part and a rich marine fauna of belemnites, ammonites, bivalves, gastropods and brachiopods,

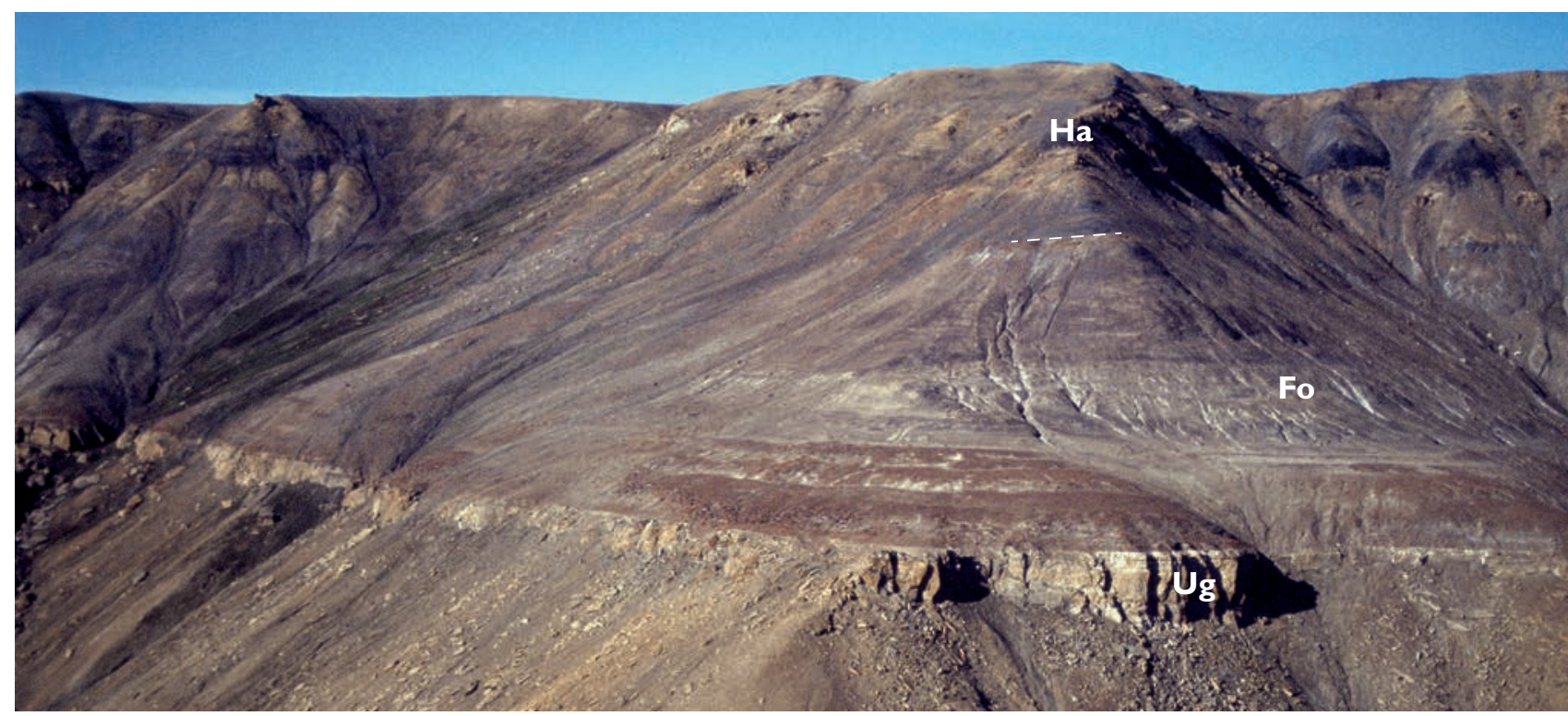

Fig. 37 North slope of the Ugleelv valley, southern Jameson Land, a classical Middle Jurassic ammonite locality (Figs 1, 2a). The lowermost unit is the clinoform-bedded, up to $30 \mathrm{~m}$ thick, uppermost yellow sandstone of the Ugleelv Member, Pelion Formation (Ug; about $20 \mathrm{~m}$ exposed at this locality). The lowest few metres of the overlying Fossilbjerget Formation has yielded a super-abundant fauna of well-preserved ammonites of the C. pompeckji zone. The change in slope between the light grey or brown-weathering mudstones and the slightly steeper slope concealing black mudstones and sandstone injectites marks the boundary between the Fossilbjerget (Fo) and Hareelv Formations (Ha) (boundary indicated). 


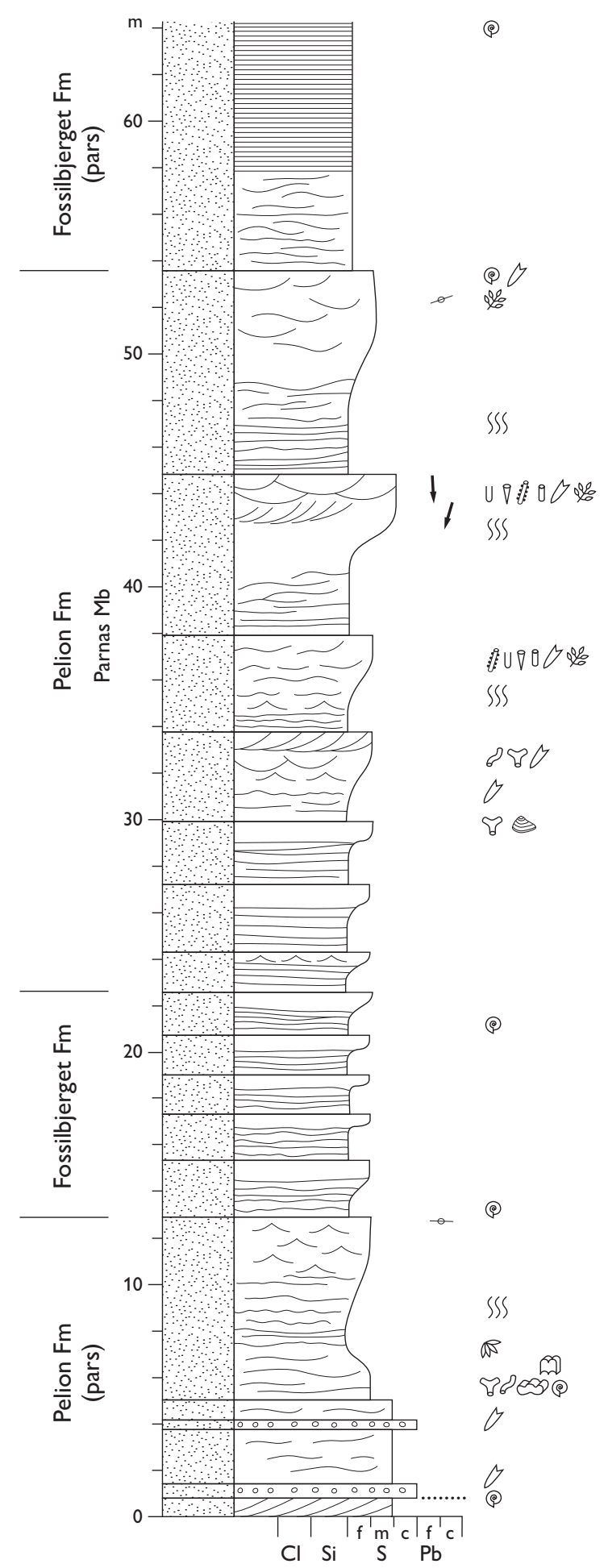

Fig. 38 Type section of the Parnas Member, Olympen, Jameson Land (Figs 1, 2a). The lower boundary of the member is placed where the backstepping motif of the Pelion-Fossilbjerget Formations changes to the forestepping motif of the progradational Parnas Member. From Engkilde \& Surlyk (2003, fig. 33). For legend, see Fig. 7.

sharply overlying grey, very fine-grained silty sandstones of the Fossilbjerget Formation. The boundary records a short-lived departure from the dominant back-stepping, northwards younging boundary between the Pelion and Fossilbjerget Formations to forward-stepping of progradational depositional units in northern Jameson Land and on Traill $\varnothing$. The upper boundary is placed at the base of grey, evenly laminated to faintly bedded silty sandstones of the upper Fossilbjerget Formation. It is a major drowning surface that marks the onset of the final back-stepping of the Pelion-Fossilbjerget couplet in the area.

Distribution. Exposed on the Olympen, Parnas and Pelion mountains and on the northern slopes of Fossilbjerget in north-central Jameson Land, in the Bjørnedal valley of south-eastern Traill $\varnothing$ (Alsen \& Surlyk 2004), and east of the Steenstrup Dal valley on southern Traill $\varnothing$ (Vosgerau et al. 2004b). Wedges out towards the south from the area of the type section and is not present at Mikael Bjerg (Figs 2a, 2c).

Chronostratigraphy. Lower Callovian, C. apertum - C. nordenskjoeldi ammonite zones (faunal horizons J-24 to J-30 of Callomon 1993), based on ammonites.

\section{Spath Plateau Member \\ History. Erected by Vosgerau et al. (2004a).}

Type section. Composite section where the lower and upper boundaries are exposed in two different ravines on the east side of the Gulelv river valley, northern Hold with Hope, $73^{\circ} 54.5^{\prime} \mathrm{N} 21^{\circ} 12.5^{\prime} \mathrm{W}$ (lower boundary), $73^{\circ} 54.6^{\prime} \mathrm{N}, 21^{\circ} 12.5^{\prime} \mathrm{W}$ (upper boundary; Vosgerau et al. 2004a, fig. 5; Figs 1, 2e, 39, 40).

\section{Thickness. $155 \mathrm{~m}$.}

Lithology. The member is dominated by coarsening-upward units of sandy heteroliths gradationally or erosionally overlain by cross-bedded fine- to coarse-grained sandstones with common mudstone-draped foresets. A silty, very fine-grained sandstone unit (c. $6 \mathrm{~m}$ thick), locally with scattered fine pebbles in the lowermost 0.5 $\mathrm{m}$, forms the basal part of the member.

Fossils. Ammonites, belemnites, bivalves, gastropods, dinoflagellate cysts, silicified and coalified wood, leaf fragments.

Depositional environment. Tidally influenced deltas with distributary channels and mouth bars in the lower-middle shoreface.

Boundaries. On Hold with Hope, the lower boundary is a sharp drowning surface marked by an abrupt change 


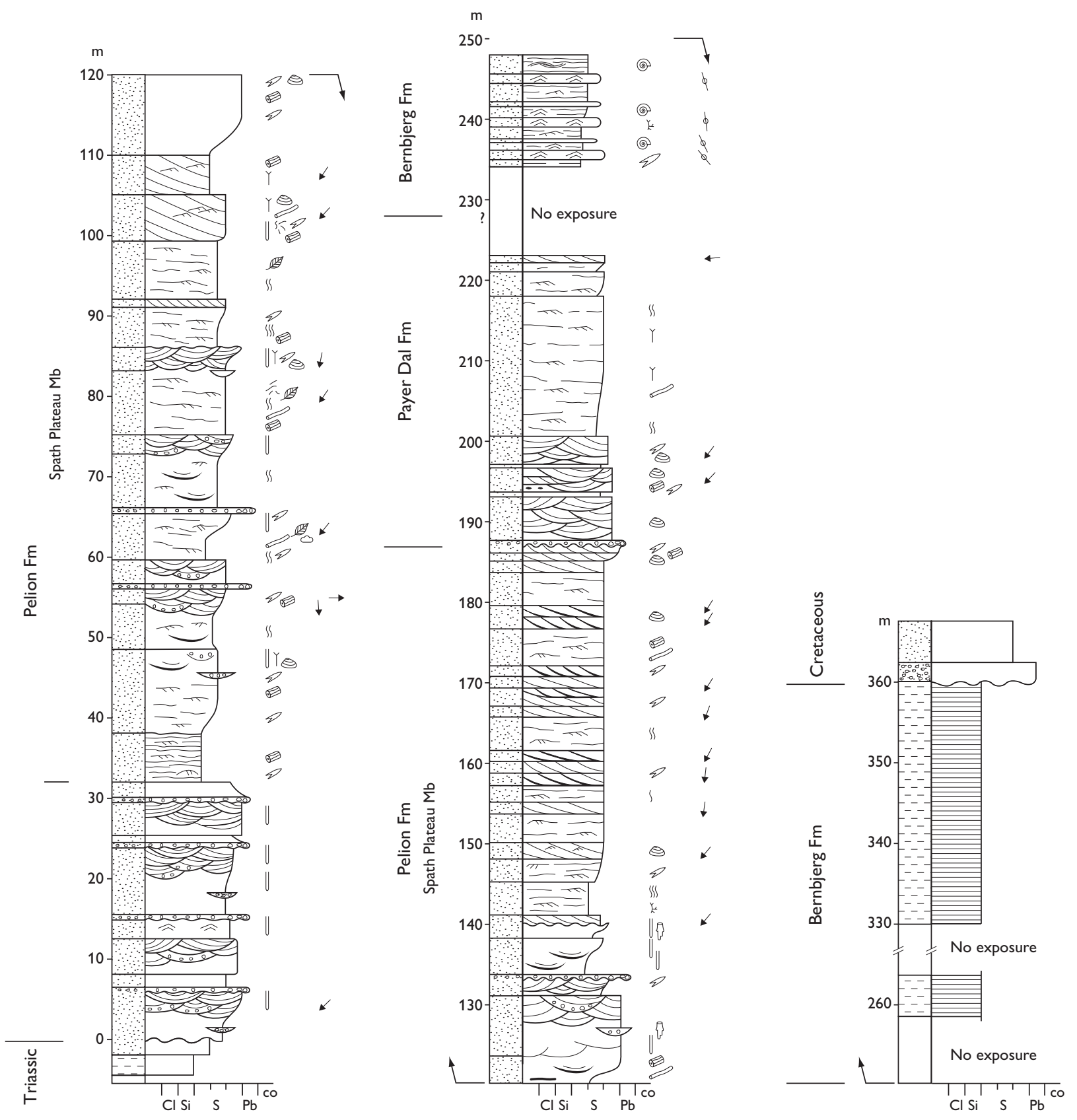

Fig. 39 Type section of the Spath Plateau Member, Gulelv, Hold with Hope (Figs 1, 2e). From Vosgerau et al. (2004a). For legend, see Fig. 7.

from coarse-grained sandstones of the lower part of the Pelion Formation (informally named 'Lower sandstone unit' in Vosgerau et al. 2004a) to dark brown, silty, finegrained sandstones at the base of the member. This basal fine-grained unit forms a $6 \mathrm{~m}$ thick marker bed, situated 30-40 m above the base of the Pelion Formation. The upper boundary is a sharp erosion surface overlain by pebbly sandstones and sandy heteroliths of the Payer Dal Formation. On Store Koldewey, it is locally overlain with erosional unconformity by the Ravn Pynt Member of the Palnatokes Bjerg Formation.

Distribution. The Spath Plateau Member is only recognised in northern Hold with Hope and on Store Koldewey (Figs 1, 2d, 2e).

Chronostratigraphy. Lower-middle Callovian, P. koenigi - pre- $P$. athleta ammonite zones, based on ammonites and dinoflagellate cysts. 


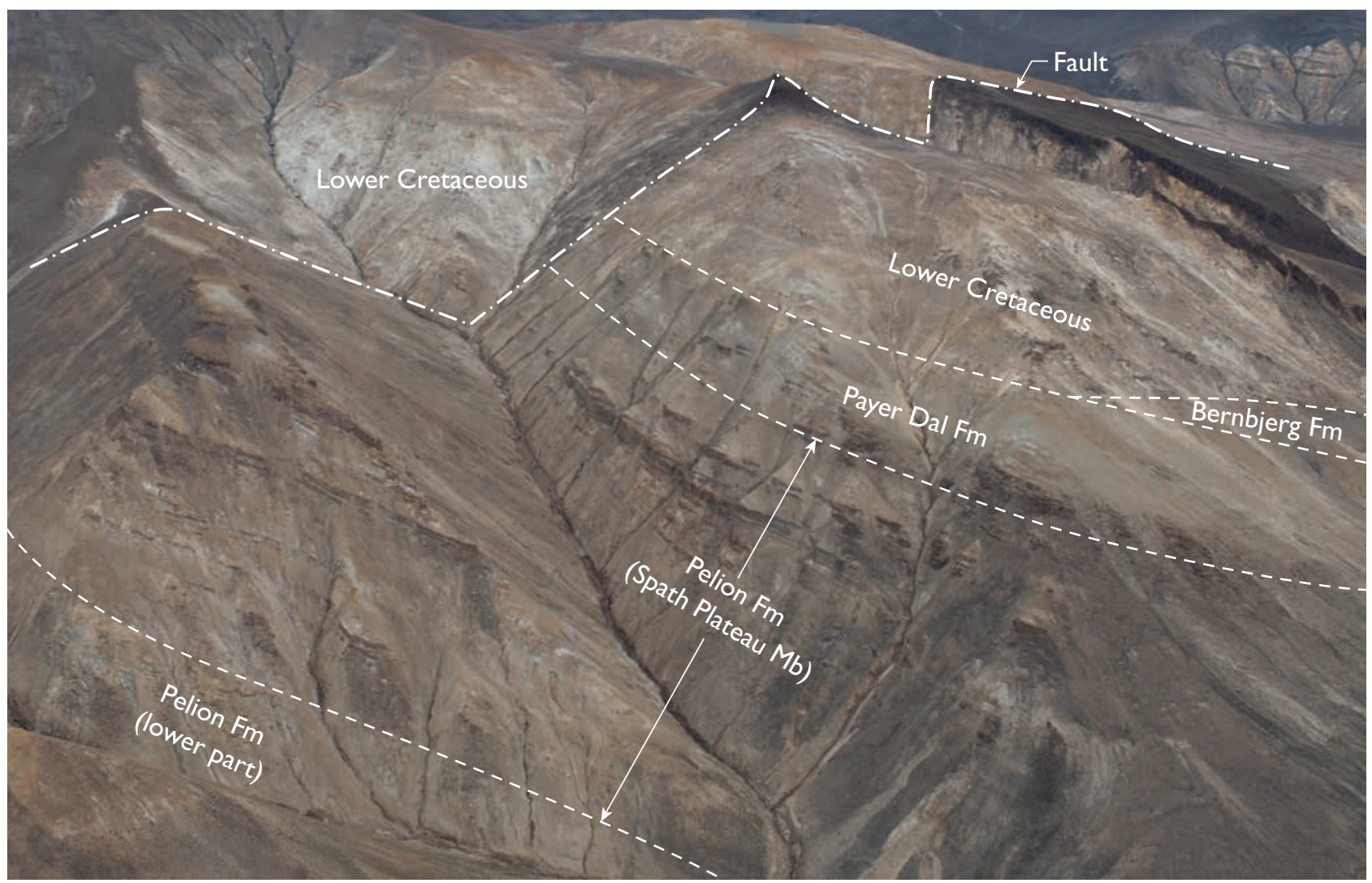

Fig. 40 Aerial photograph of the type section of the c. 155 m thick Spath Plateau Member, Pelion Formation, exposed in a fault block on the eastern side of the Gulelv river, northern Hold with Hope (Figs 1, 2e). A major drowning surface separates the member from the basal sandstone unit of the Pelion Formation. The boundary to the overlying Payer Dal Formation is a sharp erosion surface.

\section{Fossilbjerget Formation \\ revised unit}

History. Erected as the upper member of the Vardekløft Formation by Surlyk et al. (1973). Here elevated to formation rank.

Type section. Fossilbjerget, $71^{\circ} 15.1^{\prime} \mathrm{N}, 23^{\circ} 06.3^{\prime} \mathrm{W}$ (Surlyk et al. 1973, fig. 23; Figs 2a, 41).

Reference sections. Goniomyakløft, Zackenberg, Katedralen, Mikael Bjerg and Pelion in Jameson Land and Bjørnedal on Traill $\varnothing$ (Figs 1, 2a, 2c, see Fig 50).

Thickness. 80-120 m.

Lithology. Silty, highly micaceous mudstones, with subordinate fine-grained, locally glauconitic, sandstones, which become medium- to coarse-grained northward on Traill $\varnothing$. The sandstones are stacked in coarsening-upwards units. Horizons with phosphatic and calcareous concretions are common throughout.

Fossils. Ammonites in profusion, bivalves, belemnites, dinoflagellate cysts, tree trunks and trace fossils.
Depositional environment. Offshore marine.

Boundaries. In central Jameson Land, the lower boundary is placed at the base of soft, reddish-grey, silty, laminated, fossil-rich, bioturbated mudstones, overlying massive, light-grey, fine-grained to conglomeratic sandstones of the Pelion Formation. The boundary commonly weathers out as a marked ammonite- and belemnite-strewn, marine ravinement surface (Fig. 37). The lower boundary youngs from south to north and represents a northward back-stepping succession of drowning surfaces. The upper boundary is placed at a sharp contact at the base of laminated, black mudstones of the Hareelv Formation in southern Jameson Land (Figs 37, 50), and at a sharp contact at the base of light grey, structureless sandstones of the Athene Member (Olympen Formation) in central and northern Jameson Land. On Traill $\varnothing$, the Fossilbjerget Formation is overlain by sandstones of the Zeus Member (Olympen Formation).

Distribution. Mainly known from Jameson Land but has been traced northwards to Traill $\varnothing$. The sandy Parnas Member of the northwards backstepping Pelion Formation forms a southward tapering wedge within the 


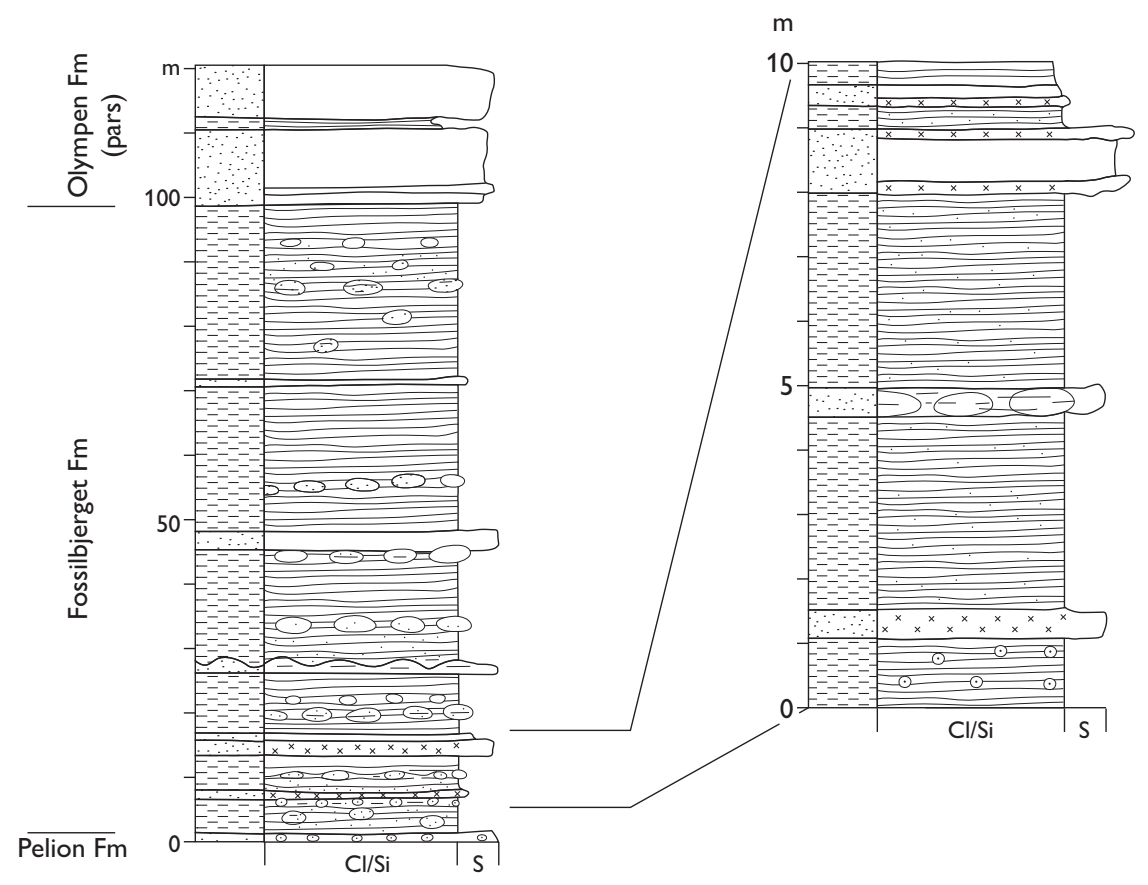

Fig. 41 Type section of the Fossilbjerget Formation, Fossilbjerget, Jameson Land (Figs 1, 2a). Modified from Surlyk et al. (1973, fig. 23). For legend, see Fig. 7.

upper levels of the Fossilbjerget Formation in north-central Jameson Land and on south-eastern Traill Ø (Fig. 1).

Chronostratigraphy. Upper Bajocian - lower upper Callovian, C. pompeckji - P. athleta zones (faunal horizons J-3 to J-37 of Callomon 1993), based on ammonites. Boundaries are strongly diachronous, both younging to the north.

Subdivision: The formation contains a new member, the Goniomyakløft Member.

Key references. Birkelund et al. (1971), Surlyk et al. (1973), Heinberg \& Birkelund (1984), Poulsen (1985), Callomon (1993), Engkilde \& Surlyk (2003), Alsen \& Surlyk (2004), Vosgerau et al. (2004b), Callomon et al. (2015).

\section{Goniomyakløft Member \\ new member}

History. Recognised as a sharp-based unit of soft, light grey weathering mudstones, about 20 m thick, forming the uppermost part of the Vardekløft Formation (of previous usage) in southern Jameson Land (Surlyk et al. 1973); corresponds broadly to the 'Wood Beds' of Callomon (1993).

Type section. Goniomyakløft, Hurry Inlet, $70^{\circ} 35.3^{\prime} \mathrm{N}$, $22^{\circ} 38.5^{\prime} \mathrm{W}$ (Surlyk et al. 1973, fig.14, section 6; Figs 1, 2a, 42).
Reference sections. Zackenberg and the east slope of the Katedralen mountain, southern Jameson Land (Callomon 1993, fig. 4; Figs 1, 2a).

\section{Thickness. About 20 m.}

Lithology. Light grey mudstones with large, greenish, irregular, extremely hard concretions commonly with a nucleus formed by a silicified log.

Fossils. Ammonites and wood.

Depositional environment. Offshore marine.

Boundaries. The lower boundary is placed where light grey to greenish, soft, laminated mudstones abruptly overlie harder, silty, dark-grey, laminated to thinly bedded mudstones with fine-grained sandstone intercalations of the lower Fossilbjerget Formation. The boundary is sharp and conceals a major hiatus corresponding to faunal horizons J-24 to J-34 of the C. apertum, C. nordenskjoeldi and lowermost $P$. koenigi ammonite zones of CalIomon (1993). The upper boundary is sharp and placed at the base of laminated black mudstones of the Hareelv Formation.

Distribution. Southern Jameson Land.

Chronostratigraphy. Top lower Callovian - lower upper Callovian, S. calloviense - P. athleta zones, based on ammonites. 


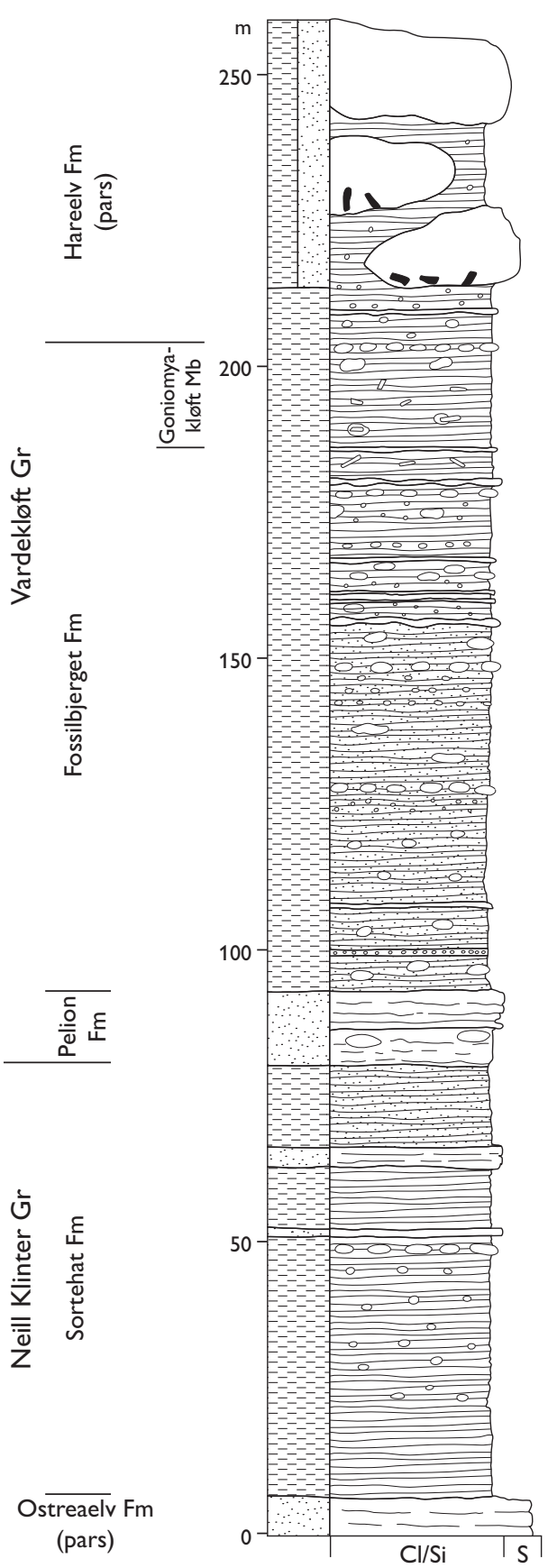

Fig. 42 Type section of the Goniomyakløft Member, Goniomyakløft, Jameson Land (Figs 1, 2a). Modified from Surlyk et al. (1973, fig. 14). For legend, see Fig. 7.

\section{Payer Dal Formation}

History. Erected by Alsgaard et al. (2003) for the upper part of the Pelion Member of Surlyk (1977a) on Kuhn $\varnothing$. The sections referred here to the Payer Dal Formation in Th. Thomsen Land and on Hochstetter Forland were previously referred to the Pelion and Jakobsstigen Members by Sykes \& Surlyk (1976) and Surlyk (1977a), respectively. The succession on Store Koldewey was previously referred to as Kløft I Formation by Koch (1929) and this was followed by Surlyk (1977a). This formation

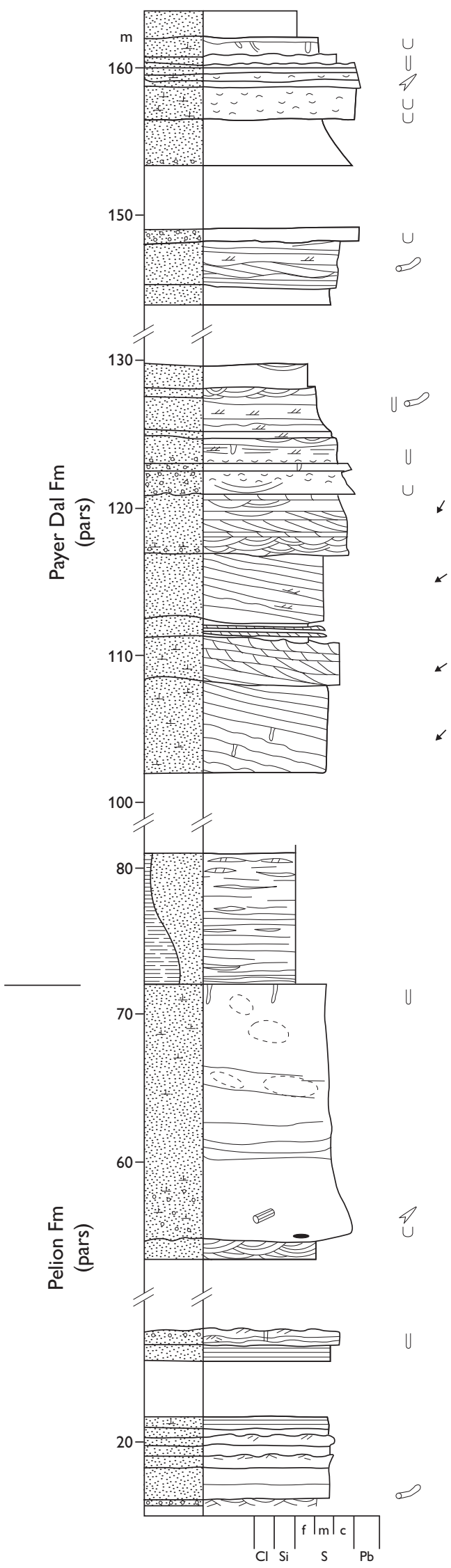

Fig. 43 Type section of the Payer Dal Formation, western slopes of Kingofjeldet on the eastern side of the Payer Dal valley, Kuhn $\varnothing$ (Figs 1, 2e). From Alsgaard et al. (2003, fig. 17). For legend, see Fig. 7. 


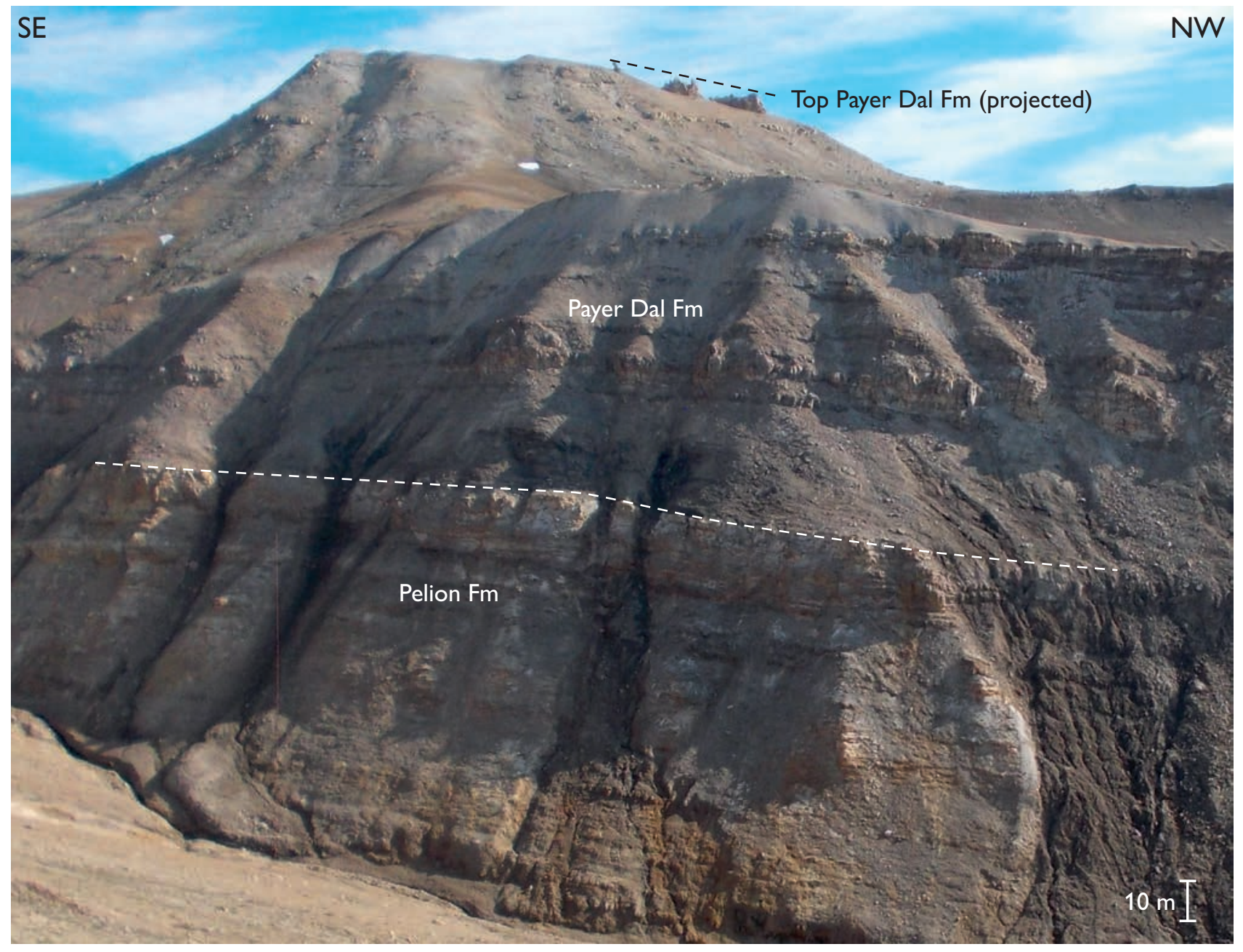

Fig. 44 Field photograph of the type section of the Payer Dal Formation. A sharp drowning surface separates the Payer Dal Formation (c. $200 \mathrm{~m}$ thick) from the underlying Pelion Formation. The boundary with the overlying Bernbjerg Formation is exposed about $1 \mathrm{~km}$ east of this locality and on the western slopes of the Payer Dal valley, Kuhn $\varnothing$ (Figs 1, 2e).

was abandoned by Piasecki et al. (2004) who referred the lower sandstone and upper mudstone units of the Kløft I Formation of Koch (1929) to the Payer Dal and Bernbjerg Formations, respectively (Figs 1, 2d, 2e).

Type section. Western slopes of Kingofjeldet, eastern side of Payer Dal, Kuhn $\varnothing, 74^{\circ} 44.9^{\prime} \mathrm{N}, 20^{\circ} 15.3^{\prime} \mathrm{W}$ (Alsgaard et al. 2003, fig. 17; Figs 1, 2e, 43, 44).

Reference sections. Ugpik Ravine, western side of Payer Dal, Kuhn $\varnothing$ and Store Koldewey (Figs 1, 2d, 2e).

Thickness. Up to $200 \mathrm{~m}$.

Lithology. Sandy heteroliths, fine- to coarse-grained, cross-bedded sandstone and pebbly sandstone. A discrete coarsening-upward unit of silty mudstones and sandy heteroliths characterises the lowermost part of the formation at Payer Dal, Kuhn $\varnothing$.
Fossils. Bivalves, belemnites, dinoflagellate cysts and trace fossils.

Depositional environment. Tidally influenced marine shoreface.

Boundaries. On Wollaston Forland and Kuhn $\varnothing$, the lower boundary is placed at the base of siltstones or heteroliths, overlying cross-bedded or structureless, carbonate-cemented sandstones of the Pelion Formation at a major drowning surface. On Hochstetter Forland, the boundary is placed at a similar drowning surface, separating the uppermost coal bed of the Muslingebjerg Formation from fine-grained, silty yellow sandstones of the Payer Dal Formation. The upper boundary is placed where black mudstones and siltstones of the Bernbjerg Formation overlie yellow sandstones. 
Distribution. Hold with Hope, Wollaston Forland, Kuhn $\varnothing$, Th. Thomsen Land, Hochstetter Forland and Store Koldewey (Figs1, 2d, 2e).

Chronostratigraphy. Uppermost Callovian - middle Oxfordian in the Wollaston Forland - Kuhn $\varnothing$ area, based on rare ammonites and dinoflagellate cysts. On Store Koldewey, upper Oxfordian - lower Kimmeridgian, A. serratum - R. cymodoce zones, based on ammonites.

Key references. Maync (1947), Sykes \& Surlyk (1976), Surlyk (1977a), Surlyk \& Clemmensen (1983), Vosgerau (1997), Alsgaard et al. (2003), Piasecki et al. (2004), Vosgerau et al. (2004a).

\section{Jakobsstigen Formation}

revised unit

History. Erected as a member of the Vardekløft Formation by Surlyk (1977a) and here elevated to the rank of formation.

Type section. The northern slope of the Cardiocerasdal valley, Wollaston Forland, named Jakobsstigen after a conspicuous flower, $74^{\circ} 27.2^{\prime} \mathrm{N}, 20^{\circ} 14.5^{\prime} \mathrm{W}$ (Surlyk 1977a, fig. 16, section 38; Figs 1, 2e, 45-47).

Reference sections. Two previously defined reference sections for the Jakobstigen Member of previous usage
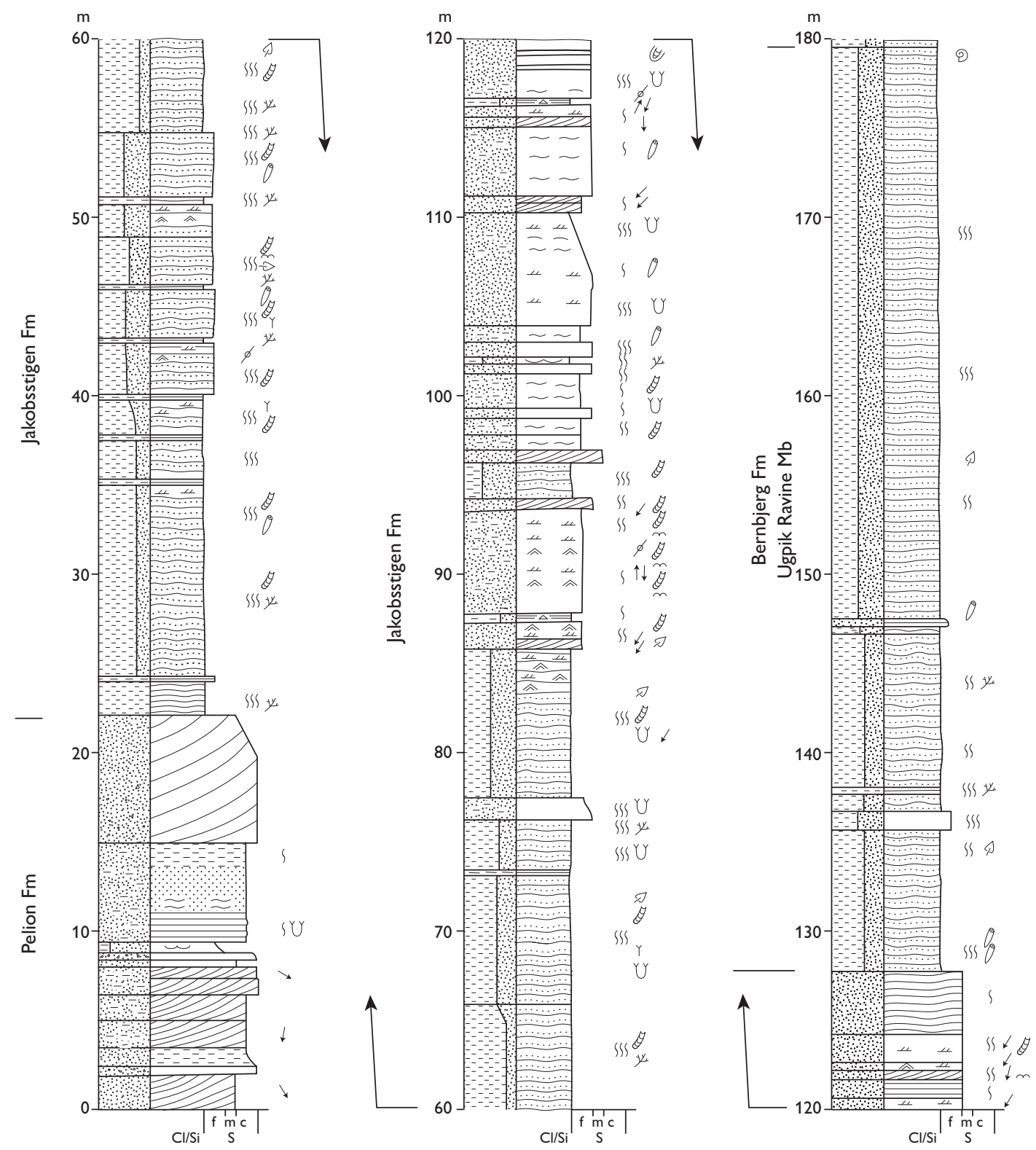

Fig. 45 Type section of the Jakobsstigen Formation, Cardiocerasdal, Wollaston Forland (Figs 1, 2e). From Surlyk (1977a, fig. 16). For legend, see Fig. 7. 


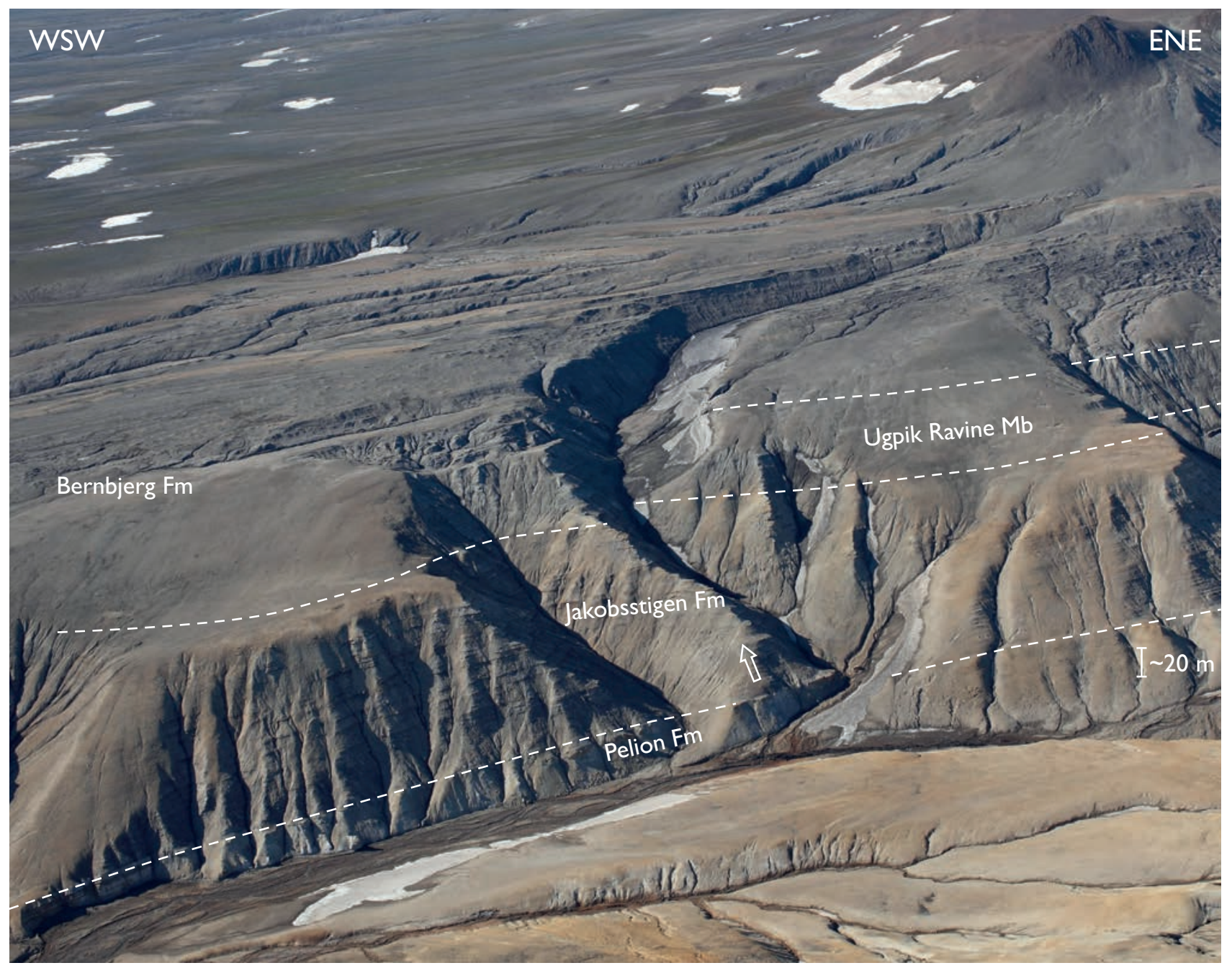

Fig. 46 Aerial photograph of the type section of the Jakobsstigen Formation (arrowed), viewed towards the NW. The formation is underlain by the Pelion Formation and overlain by the Ugpik Ravine Member of the Bernbjerg Formation. The succession shows three major drowning surfaces marking backstepping events: (1) the Pelion Formation - Jakobsstigen Formation boundary, (2) the Jakobstigen Formation - Ugpik Ravine Member (Bernbjerg Formation) boundary, and (3) the boundary between the heterolithic Ugpik Ravine Member and the dark mudstones of the upper part of the Bernbjerg Formation. North slope of the Cardiocerasdal valley, SW Wollaston Forland (Figs 1, 2e).

in Th. Thomsen Land (Surlyk 1977a, sections 2, 3) are abandoned herein as they are re-assigned to the Ugpik Ravine Member of the Bernbjerg Formation.

\section{Thickness. Up to $128 \mathrm{~m}$.}

Lithology. Strongly bioturbated heteroliths and crossbedded sandstones, forming coarsening-upward units alternating with thin black mudstones.

Fossils. Bivalves, belemnites, rare ammonites and trace fossils.

Depositional environment. Marine shoreface and possibly coastal-plain lakes or interdistributary bays.
Boundaries. The lower boundary is placed at the base of sandy heteroliths, sharply overlying cross-bedded, coarsegrained sandstones of the Pelion Formation. The upper boundary is placed at the base of dark mudstones and fine-grained heteroliths of the Bernbjerg Formation. Both boundaries are prominent marine drowning surfaces.

\section{Distribution. Wollaston Forland (Figs 1, 2e).}

Chronostratigraphy. Lower-middle Oxfordian based on ammonites.

Key references. Surlyk (1977a), Surlyk \& Clemmensen (1983), Bojesen-Kofoed et al. (1997), Vosgerau et al. (2000). 


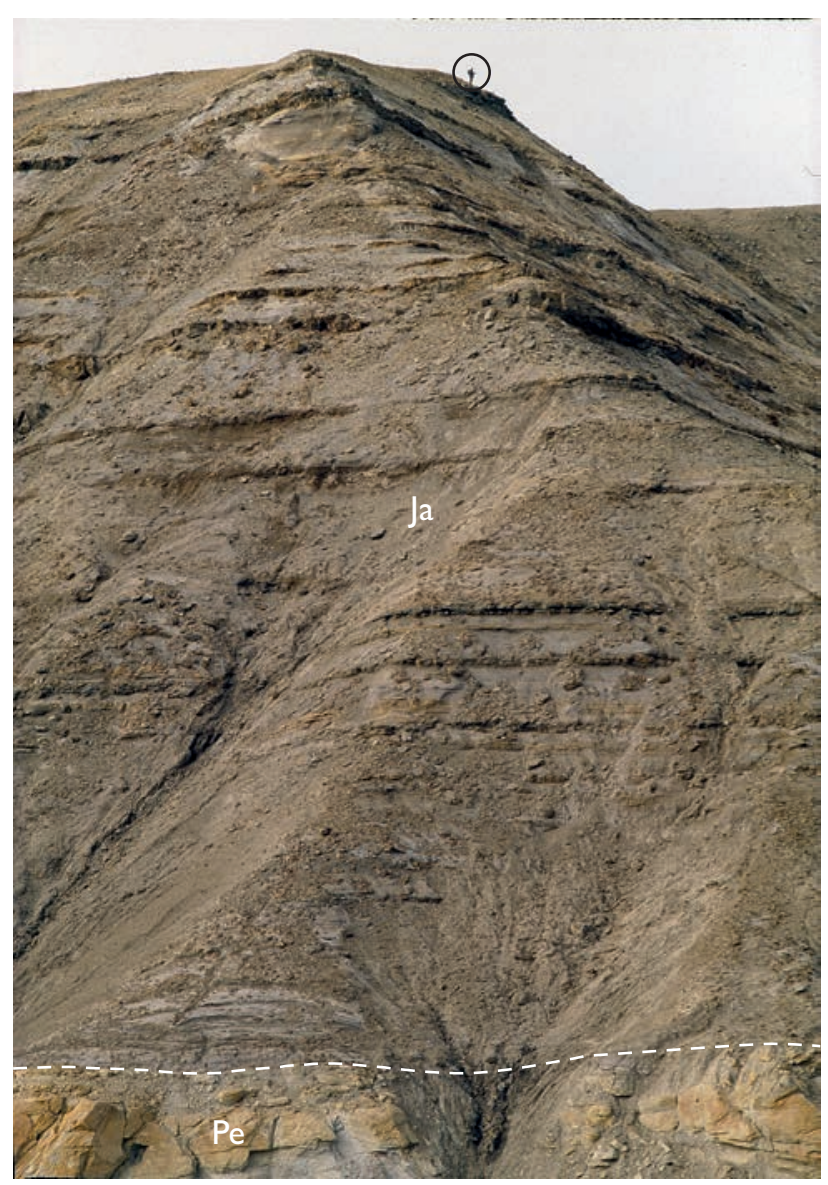

Fig. 47 The Jakobstigen Formation (Ja) on the ridge immediately west of the type section (see Fig. 46). Yellow sandstones of the Pelion Formation (Pe) at the base. Person (encircled) for scale. North slope of the Cardiocerasdal valley, SW Wollaston Forland (Figs 1, 2e).

\section{Olympen Formation}

History. Erected by Surlyk et al. (1973).

Type section. Olympelven, central Jameson Land, $71^{\circ} 24.4^{\prime} \mathrm{N}$, 2334.8'W (Surlyk et al. 1973, fig. 24a; Figs 1, 2a, 48).

Reference sections. Summit (altitude $1020 \mathrm{~m}$ ) 4 km southwest of the Olympen mountain top, Parnas and Mikael Bjerg, all in central Jameson Land, and Vælddal, southeast Traill $\varnothing$ (Figs 1, 2a, 2c).

Thickness. Forms the top unit in the type area, minimum thickness $150 \mathrm{~m}$ in the type section, $300 \mathrm{~m}$ at Parnas, wedges out southward in the Hurry Inlet area. The formation thins towards the east on Traill $\varnothing$, where the thickness is estimated to be $c .250 \mathrm{~m}$ at Bjørnedal and c. $100 \mathrm{~m}$ at Vælddal.

Lithology. In the exposures in central Jameson Land, the formation comprises (from below): massive sandstones of the Athene Member, mudstones with sandy interbeds

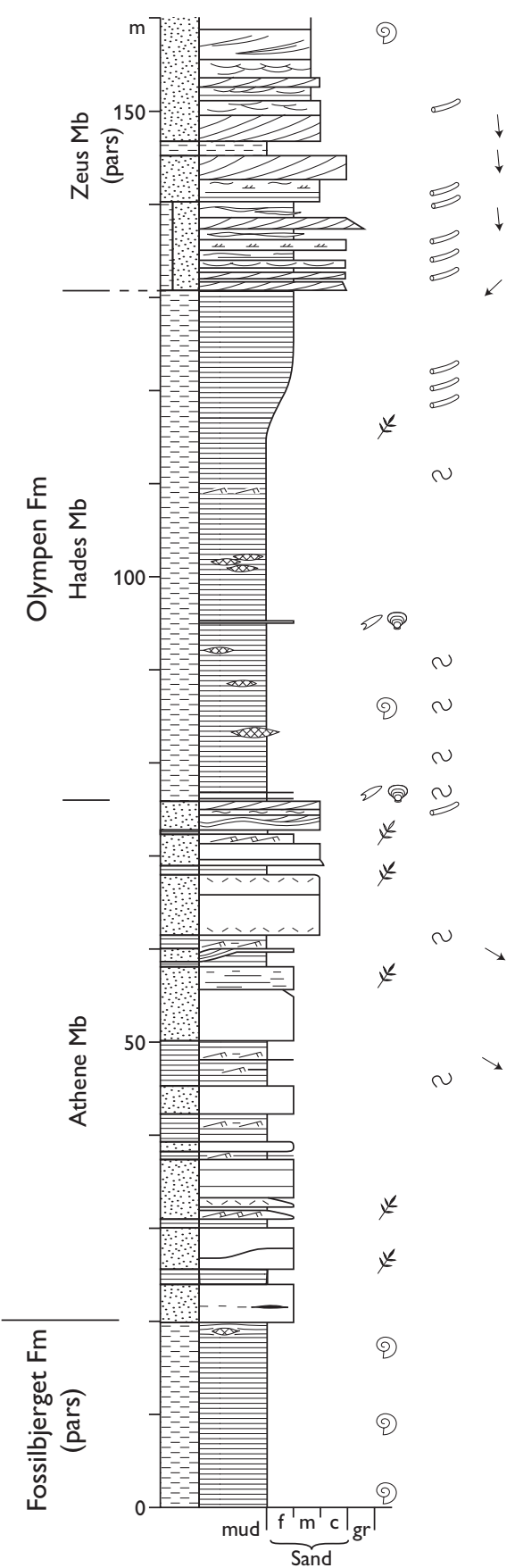

Fig. 48 Type section of the Olympen Formation and its constituent Athene, Hades and Zeus Members, Olympelven, Jameson Land (Figs 1, 2a). From Larsen \& Surlyk (2003, fig. 2). For legend, see Fig. 7.

of the Hades Member, and massive and cross-bedded sandstones of the Zeus Member. On Traill $\varnothing$, cross-bedded sandstones and intervening mudstone intervals are referred to the Zeus Member.

Fossils. Rare ammonites, bivalves, belemnites, dinoflagellate cysts, plant fragments, fossil wood and trace fossils. 
Depositional environment. Marine shelf, shelf-margin wedge, slope, base-of-slope and basin.

Boundaries. In the type section, the base of the formation (a prominent sequence boundary) is placed beneath the lowest massive sandstone bed, overlying silty mudstones of the Fossilbjerget Formation. The upper boundary is not exposed in the type section but in south-central Jameson Land, thin-bedded sandstones of the Olympen Formation are sharply overlain by black mudstones with massive sandstone injectites of the Hareelv Formation. This represents a marked marine drowning surface. On Traill $\varnothing$, sandstones referred to the Olympen Formation (Zeus Member) may be conformably overlain by black mudstones of the Bernbjerg Formation or, in places, overlain with erosional unconformity by dark mid-Cretaceous mudstones.

Distribution. Central Jameson Land and south-eastern Traill $\varnothing$ (Figs 1, 2a, 2c).

Chronostratigraphy. Upper Callovian - lower middle Oxfordian, including the $P$. athleta, Q. mariae and C. densiplicatum ammonite zones, based on ammonites and dinoflagellate cysts.

Subdivision. The formation is subdivided (from below) into the Athene, Hades and Zeus Members. Several Jurassic lithostratigraphic units included here were named after geographical features in the area whose nomenclature followed a Greek mythological theme, such as the mountains of Olympen, Pelion and Parnas. No further place names were available in the region so that additional names from Greek mythology are used to name the three constituent members of the Olympen Formation.

Key references. Surlyk et al. (1973), Birkelund et al. (1971), Surlyk (1991), Callomon (1993), Larsen \& Surlyk (2003), Bruhn \& Surlyk (2004), Vosgerau et al. (2004b), Bjerager et al. (2018a).

\section{Athene Member \\ new member}

History. Corresponds to the lower sandy unit of the Olympen Formation of Surlyk et al. (1973).

Name. From Athene (Danish spelling of Athena) who was the daughter of Zeus, eponymous goddess of the city of Athens, goddess of wisdom.

Type section. Olympelven, central Jameson Land, $71^{\circ} 24.4^{\prime} \mathrm{N}, 23^{\circ} 34.8^{\prime} \mathrm{W}$ (Larsen \& Surlyk 2003, fig. 2; Figs $2 a, 48)$.

Reference sections. Mikael Bjerg, Parnas, Pelion (Fig. 2a).

Thickness. $57 \mathrm{~m}$ in the type section.

Lithology. Massive, micaceous fine- to medium-grained sandstones, forming sheet-like beds in the lower part and thick lenticular beds in the upper part, alternating with thin mudstones and heteroliths.

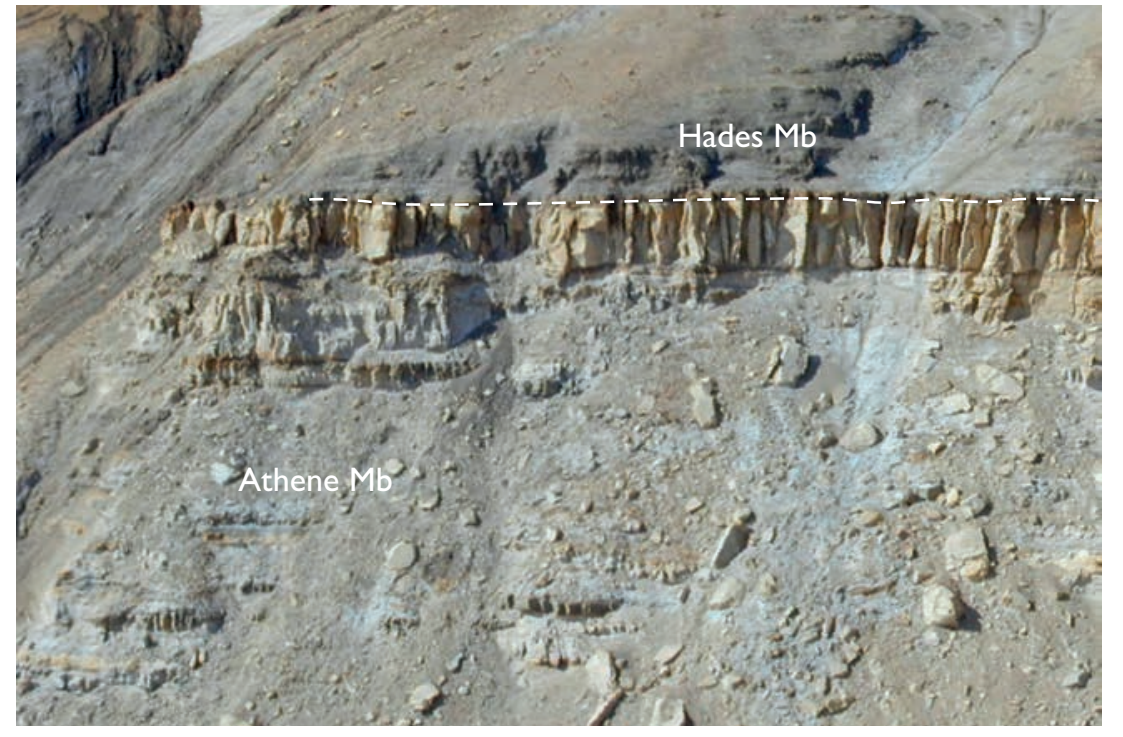

Fig. 49 Sandstones of the Athene Member (57 $\mathrm{m}$ thick) overlain by dark mudstones of the Hades Member, Olympen Formation, Olympen, Jameson Land (Figs 1, 2a). The section corresponds to the log shown in Fig. 48. Photograph by Rikke Bruhn. 
Fossils. Plant fragments, trace fossils, dinoflagellate cysts and very rare ammonites.

Depositional environment. Slope and base-of-slope.

Boundaries. The lower boundary is defined at the base of the lowest massive micaceous sandstone, overlying silty mudstone of the Fossilbjerget Formation with a sharp boundary. The upper boundary is placed where the uppermost massive sandstone bed of the Athene Member is abruptly overlain by a uniform succession of dark silty mudstones referred to the Hades Member (Fig. 49).

Distribution. Known from outcrops in central Jameson Land, and from slim-core boreholes in central western Jameson Land in the Lollandselv and Falsterelv river valleys (Bjerager et al. 2018a). The distribution in central western Jameson Land cannot be mapped in the field due to a cover of superficial deposits.

Chronostratigraphy. Upper Callovian P. athleta ammonite zone, and possibly Q. lamberti ammonite zone, based on ammonites and indirectly on dinoflagellate cysts. Includes faunal horizon J-37 of Callomon (1993).

\section{Hades Member}

new member

History. Described as the middle muddy unit of the formation by Surlyk et al. (1973).

Name. From Hades who was the ruler of the underworld according to Greek mythology.

Type section. Olympelven, central Jameson Land, $71^{\circ} 24.4^{\prime} \mathrm{N}, 23^{\circ} 34.8^{\prime} \mathrm{W}$ (Larsen \& Surlyk 2003, fig. 2; Figs $2 \mathrm{a}, 48)$.

Thickness. $39 \mathrm{~m}$ in the type section.

Lithology. Dark laminated mudstones with heterolithic intercalations.

Fossils. Ammonites, bivalves, belemnites, dinoflagellate cysts, plants and trace fossils.

Depositional environment. Base-of-slope and basin plain.

Boundaries. The lower boundary is placed at the base of dark laminated mudstones, overlying bioturbated, micaceous silty mudstones of the Fossilbjerget Formation in southern Jameson Land (see below under the Zeus Member), and massive sandstones of the Athene
Member in central Jameson Land (Fig. 49). The upper boundary is placed at the base of the lowest coarsegrained, cross-bedded or massive sandstone of the Zeus Member in central Jameson Land. Several hundreds of metres north of the type section, slope gullies filled with massive sandstones are incised into the upper Hades Member (Larsen \& Surlyk 2003, fig. 2). These sand bodies are assigned to the overlying Zeus Member and the upper boundary of the Hades Member is thus defined locally by the erosional base of these lenticular bodies. The member wedges out towards the south, and in southern Jameson Land it is represented by a dark grey mudstone succession, up to a few metres thick, overlain by black laminated mudstones with thick sandstone injectite bodies of the Hareelv Formation.

Distribution. Central and southern Jameson Land.

Chronostratigraphy. Lower middle Oxfordian, including the Q. mariae ammonite zone, based on ammonites and indirectly on dinoflagellate cysts. Includes faunal horizon J-38 of Callomon (1993).

\section{Zeus Member \\ new member}

History. Described as the upper sandy unit of the formation by Surlyk et al. (1973).

Name. From Zeus who was the ruler of the ancient Greek Olympic gods, the highest god in the Greek pantheon.

Type section. Olympelven, central Jameson Land, $71^{\circ} 24.4^{\prime} \mathrm{N}$, 2334.8'W (Larsen \& Surlyk 2003, fig. 2; Figs 2a, 48).

Thickness. At least $50 \mathrm{~m}$, probably as much as $250 \mathrm{~m}$.

Lithology. Coarse-grained, cross-bedded sandstones, locally with wave ripples, and massive sandstones to the south.

Fossils. Rare ammonites, plants and trace fossils.

Depositional environment. Shallow marine shelf on Traill $\varnothing$, shelf-margin wedge and slope and base-of-slope in central Jameson Land.

Boundaries. The lower boundary is placed at the base of the lowest sandstone, abruptly overlying dark mudstones of the Hades Member in central Jameson Land, and overlying silty mudstones of the Fossilbjerg Formation with a gradational or sharp boundary on Traill $\varnothing$. The upper boundary is not exposed at the type section. Elsewhere, it is placed at the base of black mudstones 
with sandstone injectites of the Hareelv Formation in Jameson Land, and at the base of black mudstones of the Bernbjerg Formation on Traill $\varnothing$.

Distribution. Central Jameson Land and south-eastern Traill $\varnothing$. In southern Jameson Land, thin distal Hades Member mudstones, overlying the Fossilbjerget
Formation, coarsen upward into facies transitional to the Zeus Member.

Chronostratigraphy. Lower-middle Oxfordian, Q. mariae - C. densiplicatum zones, based on ammonites and indirectly on dinoflagellate cysts. Includes faunal horizons J-38 to J-40 of Callomon (1993).
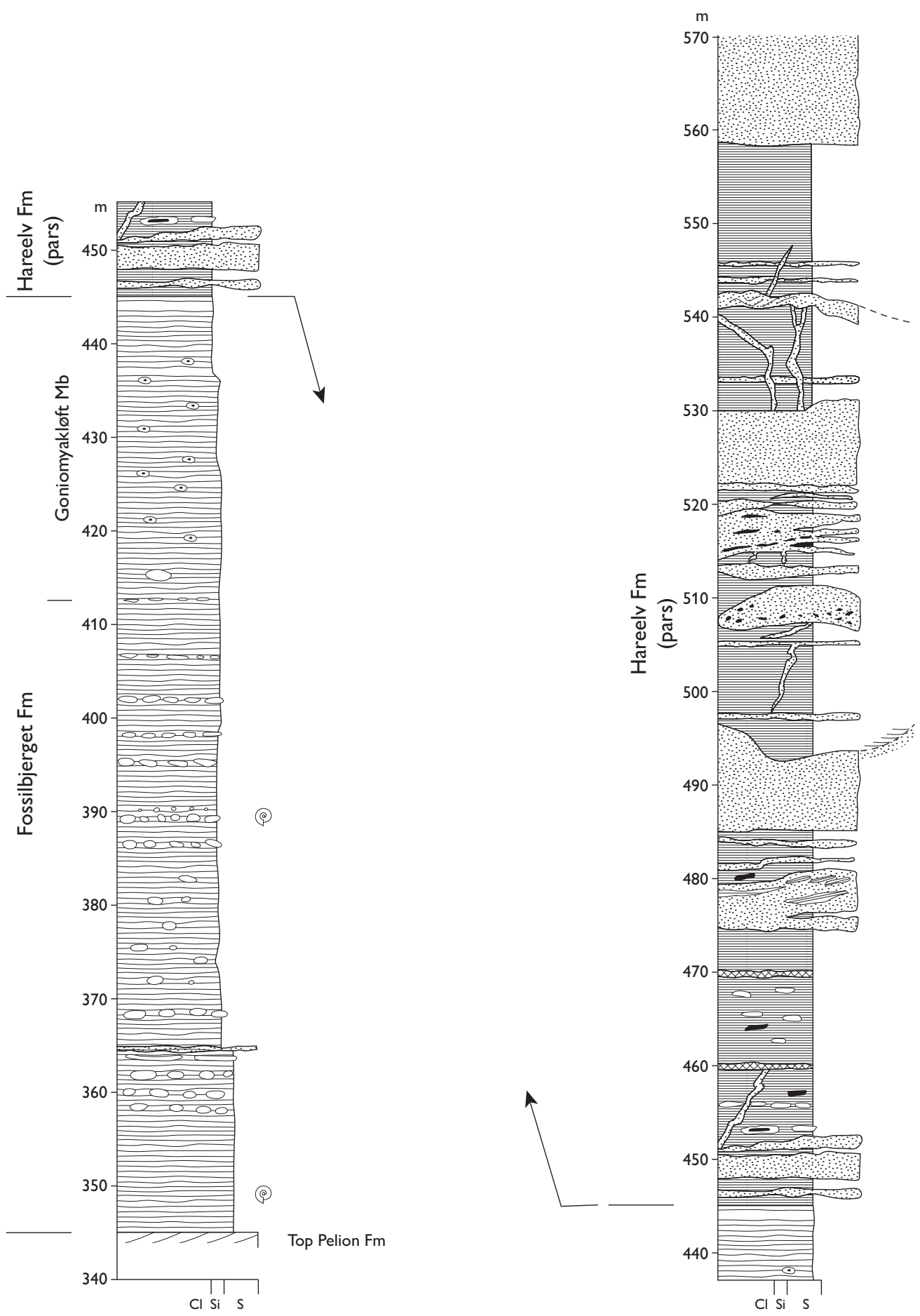

Fig. 50 Type section of the Hareelv Formation, Katedralen, Ugleelv, Jameson Land (Figs 1, 2a). For legend, see Fig. 7. 

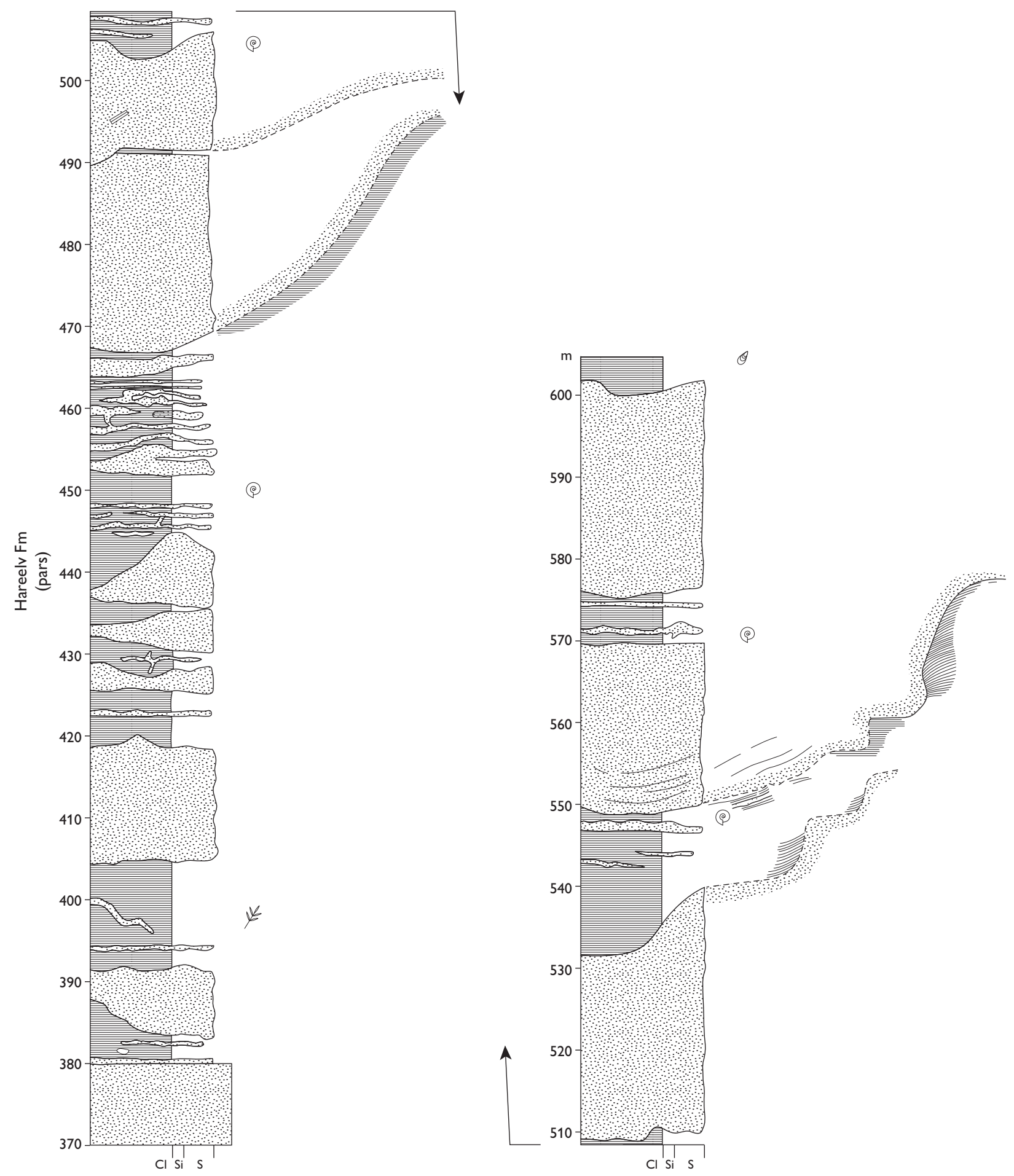

Fig. 51 Reference section of the Hareelv Formation, Gåseelv, Jameson Land (Figs 1, 2a). For legend, see Fig. 7.

\section{Hareelv Formation}

History. Erected by Surlyk et al. (1973). In a provisional presentation of this revised stratigraphy, Surlyk (2003, fig. 5) transferred the Sjællandselv and Salix Dal Members from the overlying Raukelv Formation to the
Hareelv Formation and an additional member (Katedralen Member) was provisionally introduced. These proposals were followed in Bjerager et al. $(2018 \mathrm{a}, \mathrm{b})$ but are not formalised here. The Hareelv Formation is not subdivided, and the Sjællandselv and Salix Dal Members 


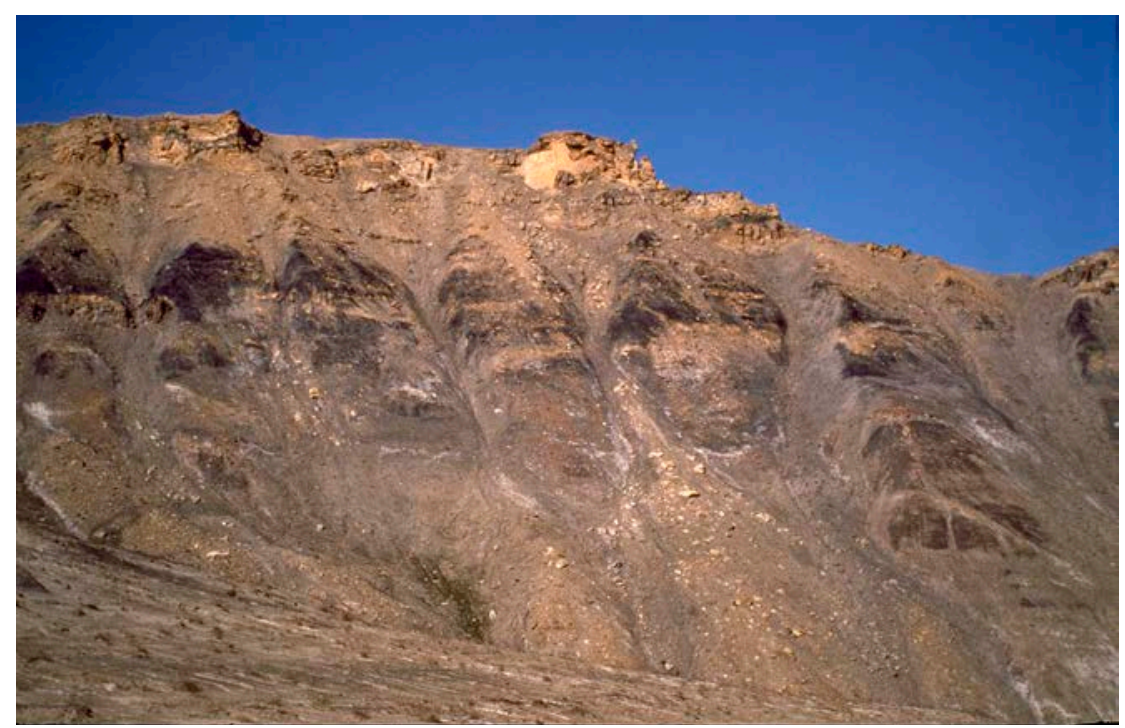

Fig. 52 Hareelv Formation, showing black mudstones and complex sandstone injectites. Section about $50 \mathrm{~m}$ high. Katedralen, Ugleelv, southern Jameson Land (Figs 1, 2a).

are retained in the Raukelv Formation as originally defined by Surlyk et al. (1973).

Type section. The original, rather poorly exposed type section of Surlyk et al. (1973) is here substituted by a new, well-exposed type section at Katedralen, southern Jameson Land, $70^{\circ} 53.3^{\prime} \mathrm{N}, 22^{\circ} 55.2^{\prime} \mathrm{W}$ (Figs 1, 2a, 50).

Reference sections. Katedralen, Gåseelv (Fig. 51), Hareelv, Goniomyakløft (Surlyk et al. 1973, fig. 14; Fig 2a); Bloklev-1 slim-core, available for study at GEUS, Copenhagen (see Bjerager et al. 2018 a, b).

Thickness. Probably up to about $400 \mathrm{~m}$.

Lithology. Dark laminated organic-rich mudstones interbedded with massive lenticular sandstone injectites. Pervasive sand injectites, including dykes and sills on all scales (Figs 50-52). Mudstone clasts and thin finegrained turbidite sandstones are common.

Fossils. Ammonites, bivalves, dinoflagellate cysts, logs, minute trace fossils at some levels.

Depositional environment. Slope, base-of-slope and basin plain.

Boundaries. In south-west Jameson Land, the lower boundary is placed at the base of black, laminated mudstones, sharply overlying a few metres thick wedge of dark Hades Member mudstones of the Olympen Formation. Elsewhere, it is placed where black laminated mudstones overlie sandstones of the Zeus Member
(Olympen Formation) or grey micaceous silty mudstones of the Fossilbjerget Formation. The Hareelv Formation is typically succeeded conformably by the Raukelv Formation, the boundary being placed at the base of marine, massive sheet-like sandstones of the Sjællandselv Member. It is possible that the formation is overlain by the clinoform-bedded Langelandselv Member in the subsurface of south-west Jameson Land. In a localised area of southernmost Jameson Land, the upper boundary is placed at a sharp, erosional surface overlain by bioturbated mudstones referred to the Lower Cretaceous (Ryazanian) Hesteelv Formation. Further details on this boundary are given under the Hesteelv Formation.

Distribution. Southern Jameson Land (Figs 1, 2a).

Chronostratigraphy. Upper Oxfordian - lower Volgian, A. glosense (faunal horizon J-41 of Callomon, 1993) - P. elegans zones, based on ammonites and dinoflagellate cysts. In the subsurface (south-west Jameson Land), the formation extends down into the Middle Oxfordian C. densiplicatum zone (Bjerager et al. 2018a). Upper boundary diachronous, younging towards the south.

Key references. Surlyk et al. (1973), Surlyk (1987), Surlyk \& Noe-Nygaard (2001b, 2003), Surlyk et al. (2007), Alsen \& Piasecki (2018), Bjerager et al. (2018b). 


\section{Bernbjerg Formation}

History. Erected by Surlyk (1977b).

Type section. Bernbjerg, Kuhn $\varnothing 74^{\circ} 46.9^{\prime} \mathrm{N}, 20^{\circ} 19.7^{\prime} \mathrm{W}$

(Surlyk 1977a, fig. 24, section 8; Figs 1, 2e, 53).

Reference sections. The reference sections follow the numbering of Surlyk (1977a) and are illustrated therein:
Bernbjerg (section 9), Perisphinctes Ravine (section 10), 'Nord profil' Kuhn $\varnothing$ (section 12), Cardiocerasdal (sections 38, 40), Stratumbjerg (section 41; Fig. 54; Figs 1, 2e).

Thickness. Up to about $600 \mathrm{~m}$.

Lithology. Dark grey to black mudstones, which may be silty or sandy. Basal 20-75 m dominated by mudstone
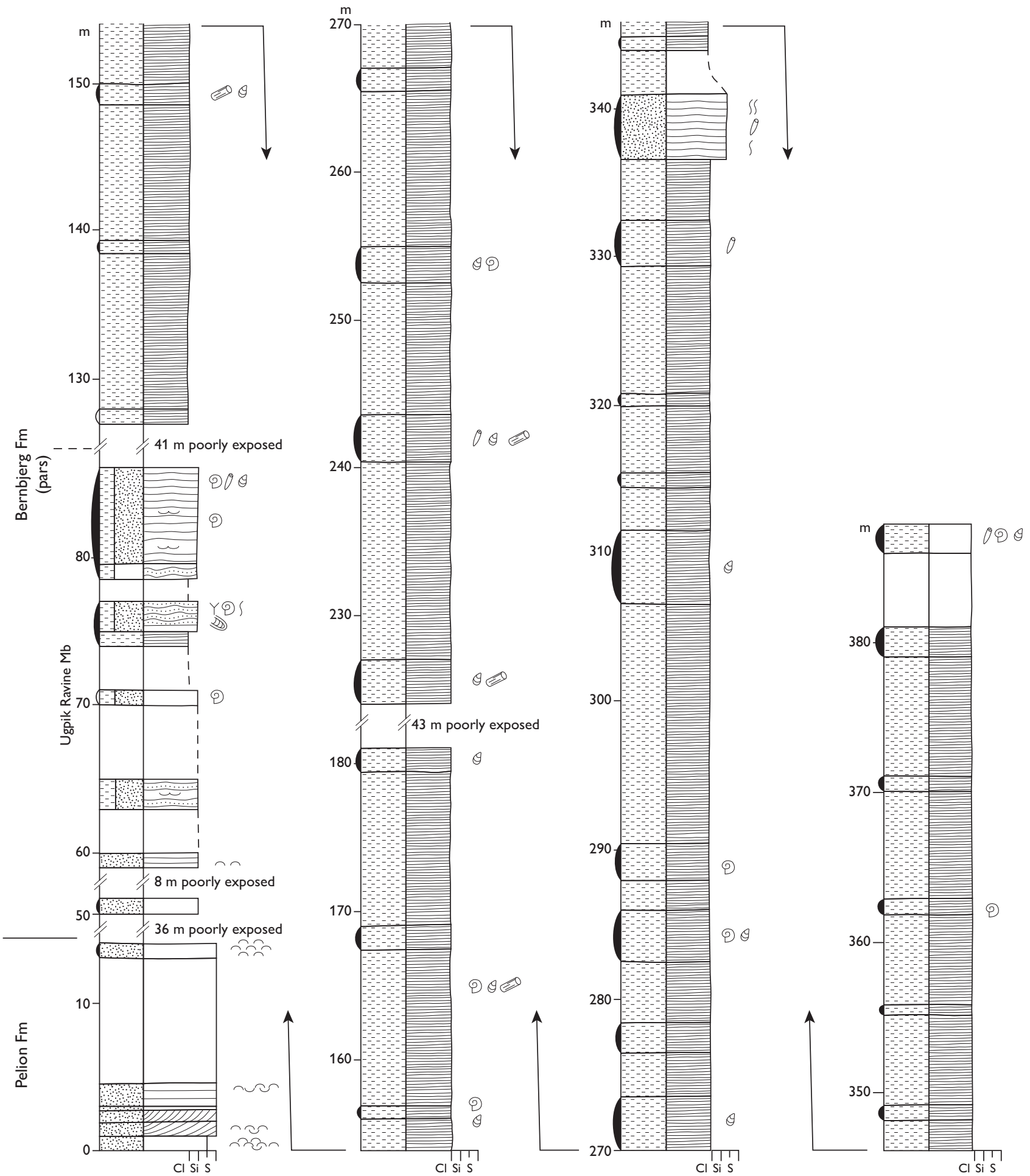

Fig. 53 Type section of the Bernbjerg Formation, Bernbjerg, Kuhn $\varnothing$ (Figs 1, 2e). From Surlyk (1977a, fig. 24). For legend, see Fig. 7. 


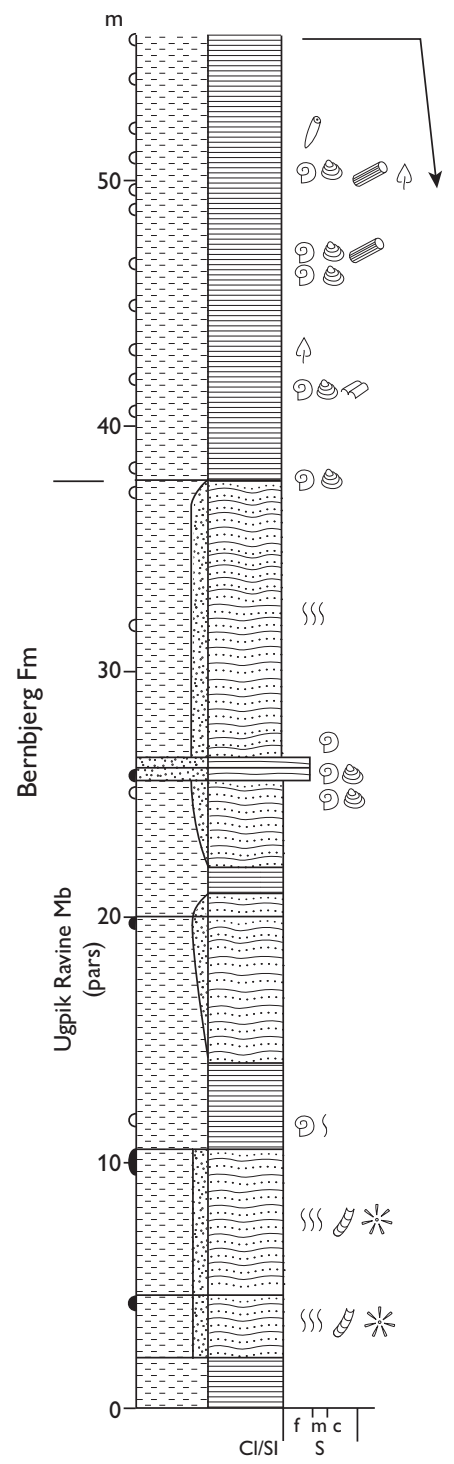

Fig. 54 Reference section of the Bernbjerg Formation, Stratumbjerg, Wollaston Forland (Figs 1, 2e). From Surlyk (1977a, fig. 32). For legend, see Fig. 7.

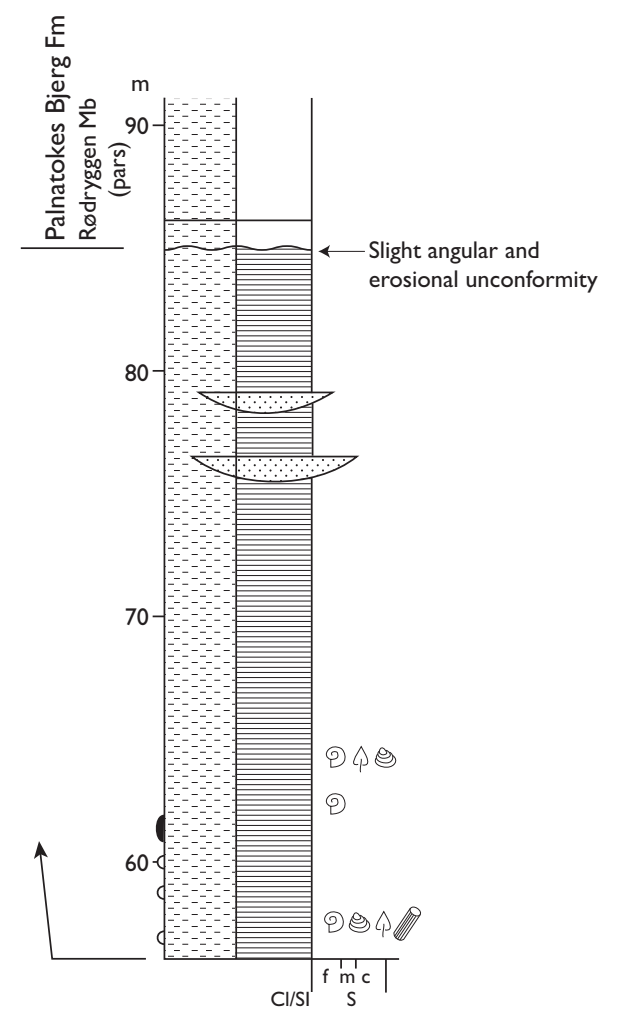

or sandy heteroliths. Thin graded sandstone turbidites are common in the mudstones in some areas.

Fossils. Ammonites, belemnites, the bivalve Buchia, wood fragments and logs, rare vertebrates, dinoflagellate cysts and trace fossils.

\section{Depositional environment. Offshore marine.}

Boundaries. The lower boundary is placed where dark grey to black mudstones and sandy heteroliths abruptly overlie sandstones of the Olympen Formation (Traill Ø), sandstones of the Payer Dal Formation (Hold with Hope, Kuhn $\varnothing$, Hochstetter Forland and Store Koldewey), or sandstones or heteroliths of the Jakobsstigen Formation (Wollaston Forland). The lower boundary is interpreted as a regional, northwards younging, diachronous drowning surface. The upper boundary is an erosional unconformity at the base of the conglomerate-dominated Rigi and Laugeites Ravine Members of the Lindemans Bugt
Formation and, more distally (eastwards) in Wollaston Forland by dark sandy mudstones of the Niesen Member (Wollaston Forland - Kuhn Ø). On Traill $\varnothing$ and Store Koldewey, it is overlain with erosional unconformity by Aptian mudstones of the Stratumbjerg Formation.

Distribution. Traill $\varnothing$, Hold with Hope, east coast of Clavering $\varnothing$, Wollaston Forland, Kuhn $\varnothing$, Th. Thomsen Land, Hochstetter Forland, Store Koldewey (Figs 1, 2c, 2d, 2e).

Chronostratigraphy. Upper Oxfordian - lower Volgian, $A$. glosense - probably $P$. wheatleyensis ammonite zones, based on ammonites.

Subdivision. A new member, the Ugpik Ravine Member, is defined here.

Key references. Maync (1947), Sykes \& Surlyk (1976), Surlyk (1977a, 1978c, 2003), Alsgaard et al. (2003), Vosgerau et al. (2004a, b), Bjerager et al. (2020). 

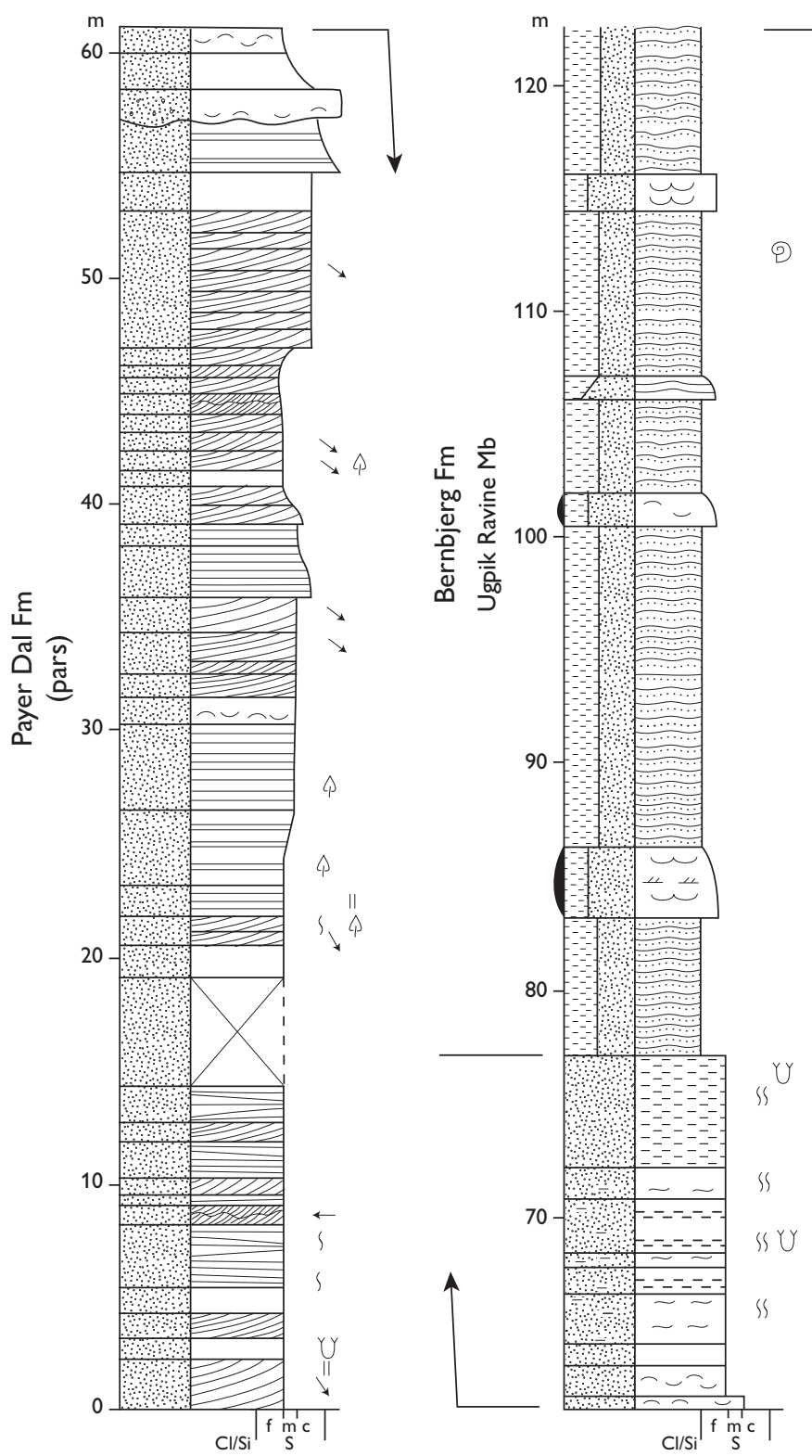

Fig. 55 Type section of the Ugpik Ravine Member, Ugpik Ravine, Kuhn $\varnothing$ (Figs 1, 2e). From Surlyk (1977a, fig. 4). For legend, see Fig. 7.

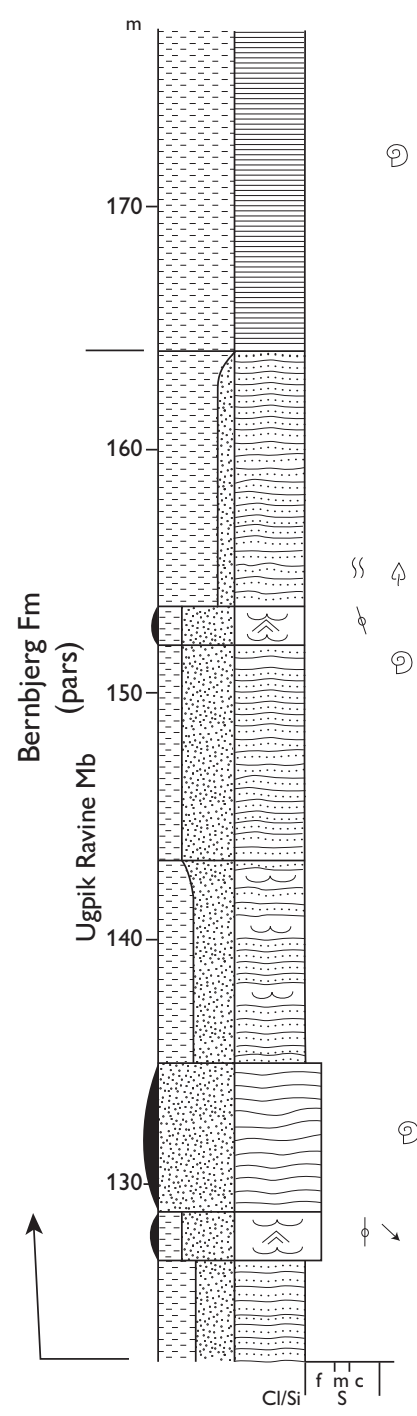

\section{Ugpik Ravine Member}

new member

History. The member includes some of the deposits described under the term 'Grey Series' by Maync (1947). The 'Grey Series', however, referred to a heterolithic facies type that occurs at several levels in the MiddleUpper Jurassic succession of Wollaston Forland and Kuhn $\varnothing$ (Maync 1947; Surlyk 1977a). The 'Grey Series' is thus a facies term and not a lithostratigraphic unit and did not form the basis for a formal lithostratigraphic unit in the scheme of Surlyk (1977a).

Name. After a creek in eastern Payer Dal, Kuhn $\varnothing$, termed Ugpik Ravine by Maync (1947, p. 18). Ugpik is Greenlandic for snowy owl.
Type section. Ugpik Ravine, southern Kuhn $\varnothing, 74^{\circ} 45.3^{\prime} \mathrm{N}$, 20²1.3'W (Surlyk 1977a, fig. 4, section 1; Figs 1, 2e, 55).

Reference sections. The reference sections follow the numbering of Surlyk (1977a) and are illustrated therein: Wollaston Forland (section 38; Fig. 46) and Kuhn $\varnothing$ (sections 1, 8, 9; Figs 1, 2e).

Thickness. 85-100 m in Cardiocerasdal, Wollaston Forland, and up to about $75 \mathrm{~m}$ on Kuhn $\varnothing$ (Figs 1, 2e).

Lithology. Bioturbated, mainly wavy laminated sandy heteroliths, but flaser and lenticular laminated heteroliths also occur.

Fossils. Ammonites, belemnites, bivalves, plant fragments, dinoflagellate cysts and trace fossils. 


\section{Depositional environment. Offshore transition zone.}

Boundaries. The lower boundary is the same as for the formation, and is placed at a marked drowning surface, separating the basal heteroliths of the member from the underlying sandstones of the Payer Dal Formation on Hold with Hope, Kuhn $\varnothing$, Hochstetter Forland and Store Koldewey, and from the underlying sandstones or heteroliths of the Jakobsstigen Formation on Wollaston Forland. The upper boundary is sharp and placed at the base of mud-dominated heteroliths or laminated mudstones of the upper Bernbjerg Formation, overlying sandy heteroliths. This boundary represents a drowning surface (Figs 45, 46, 55).

Distribution. Hold with Hope, Wollaston Forland, Th. Thomsen Land, Kuhn $\varnothing$ and Hochstetter Forland (Figs 1, 2e).

Chronostratigraphy. Upper Oxfordian (A. glosense, A. serratum, $A$. regulare and $A$. rosenkrantzi ammonite zones) - lower Kimmeridgian ( $P$. baylei and R. cymodoce zones), based on ammonites.

\section{Raukelv Formation \\ revised formation}

Introductory remarks. The Raukelv Formation was erected by Surlyk et al. (1973) for a succession of coarse-grained, marine high-angle clinoform-bedded, large-scale cross-bedded or massive sandstones of Volgian age exposed in southernmost Jameson Land. It represents the final infilling of the basin, forming the regressive upper part of the Middle Jurassic - lowermost Cretaceous transgressive-regressive megacycle. The massive sandstones of the Sjællandselv Member and the mudstones of the Salix Dal Member represent slope-basinal redeposited sands and basinal muds, respectively. The Sjællandselv Member represents basinal sedimentation during each progradational clinoform pulse formed by collapse of the clinoform fronts, and the Salix Dal Member represents basinal mud accumulation during each intervening shelf-edge aggradational phase.

The Raukelv Formation is very well exposed but due to the combination of low altitude and subdued topography, and the great thickness of the clinoform beds, many sections only show a single bed and long, continuous vertical sections through a number of stacked beds can only rarely be measured. Some of the figured type or reference sections therefore only show part of the unit in question, and the uppermost member - the Rauk Plateau Member - is only illustrated with field photographs.
History. As originally defined by Surlyk et al. (1973), the Raukelv Formation comprised three members, in stratigraphic order, the Sjællandselv, Salix Dal and Fynselv Members. The Fynselv Member is revised here, being restricted to include only the major, landscape-forming high-angle clinoform bed, which formed the main element (bed D) of the original definition of the member by Surlyk et al. (1973).

Name. After the Raukelv river in southernmost Jameson Land (Figs 1, 2a).

Type area. Plateau around the upper reaches of the Raukelv river (Fig. 2a). As noted above, the formation is defined from a number of short sections that typically exhibit only a single member or part thereof. The formation is thus defined by the type sections of its component members.

Reference sections. Good sections are found in canyons of the eastern and western branches of the Fynselv river (Fig. 2a), and in the northern reaches of the Langelandselv river (Fig. 2a).

Thickness. Probably around $400 \mathrm{~m}$, but difficult to estimate as only a few members are exposed in even the largest vertical outcrops due to the low altitude and hence subdued relief of southernmost Jameson Land.

Lithology. High-angle clinoform-bedded, coarse-grained, commonly pebbly sandstone beds, up to $50 \mathrm{~m}$ thick, alternate with intervals of large-scale planar or mediumscale trough cross-bedded pebbly sandstones and bioturbated siltstones. In some cases, the upper, frontal part of thick clinoform beds display curved slump scars draped by massive sandstones. Similar massive resedimented sandstones forming parallel-bedded successions are referred to the Sjællandselv Member. Such massive sandstone beds are very uniform, mainly unfossiliferous, and are essentially devoid of any diagnostic features.

Fossils. Ammonites, bivalves, belemnites, crinoids, trace fossils, wood and plant fragments.

Depositional environment. Extensive shelfal sandwave fields, shelf-margin wedges, shelf-slope break, slope, base-of-slope and basin.

Boundaries. The lower boundary is placed at the base of the lowest thick, massive sandstone bed of the Sjællandselv Member, overlying black mudstones with sandstone injectites of the Hareelv Formation. The upper boundary is placed at a major canyon-shaped erosional 
www.geusbulletin.org

a

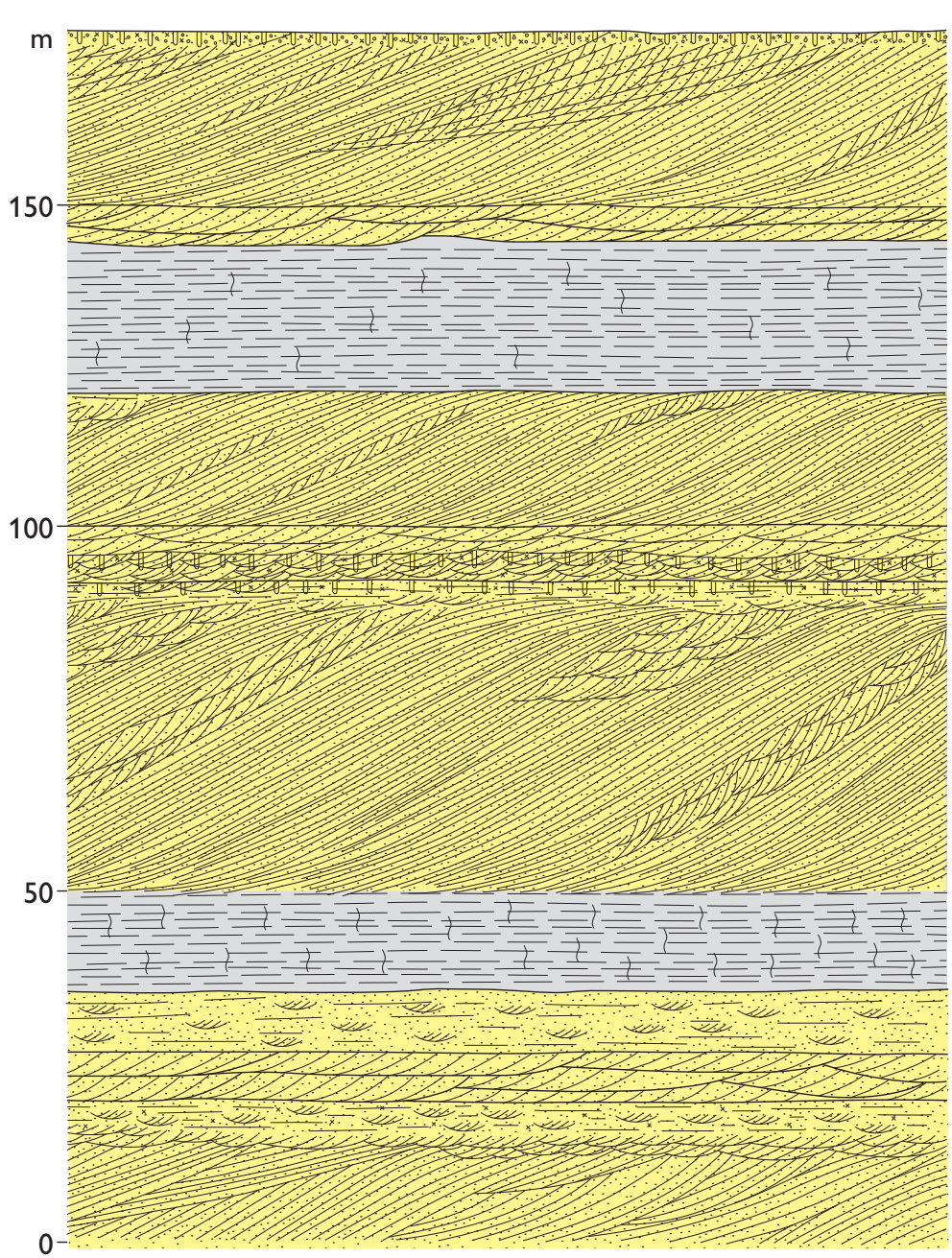

Key

Facies surfaces Members

O-SB4

SB
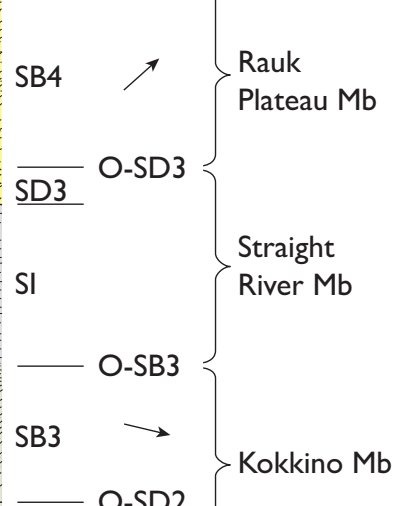

SB2

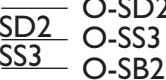

OS3 3 -SB2
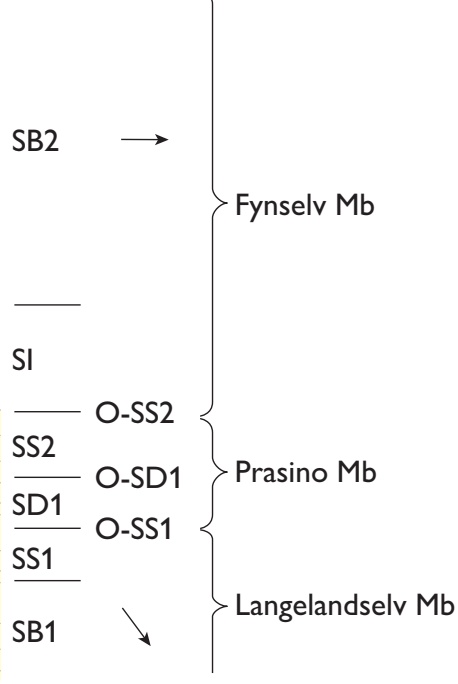

b

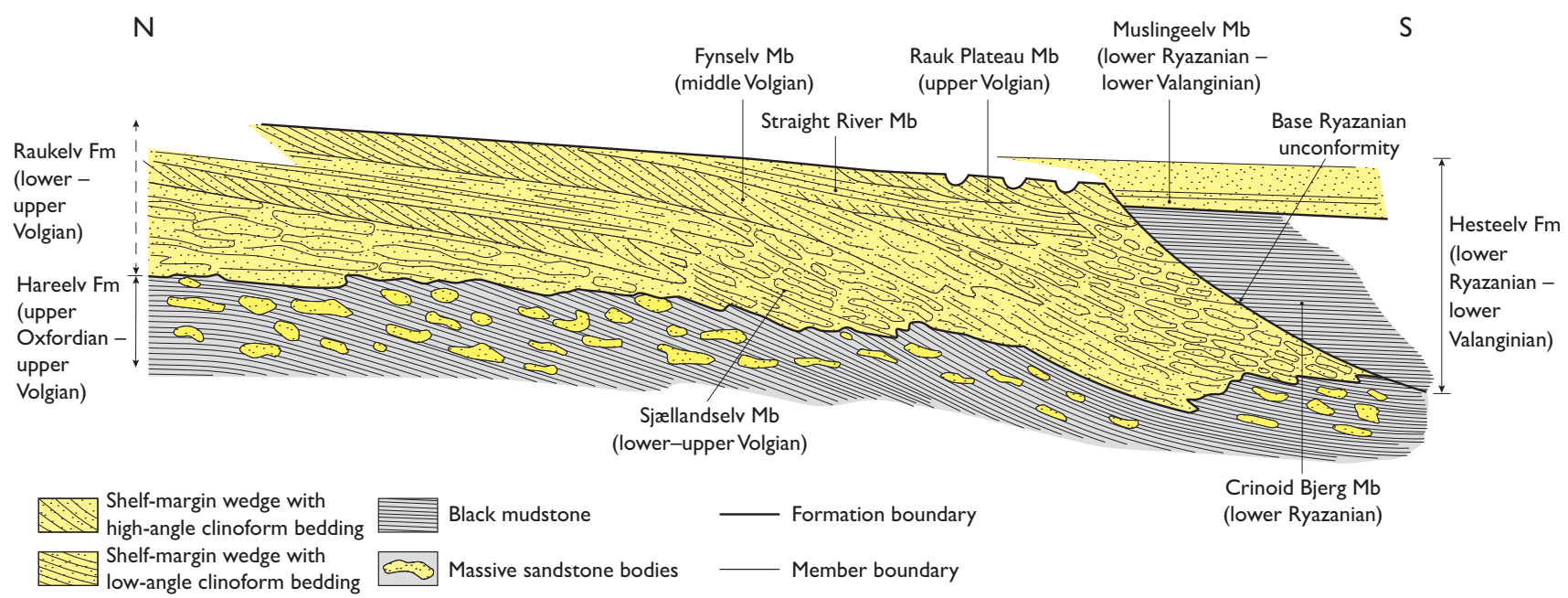

Fig. 56 Raukelv Formation stratigraphic relationships. (a) Schematic section through the upper part of the Raukelv Formation, above the Sjællandselv and Salix Dal Members, showing symbols used for beds and surfaces. SB: sand bank. SD: sand dune. SS: sand sheet. SI: siltstone. O-SB, O-SD and O-SS indicate omission surfaces bounding the individual beds. Scale is approximate. This figure is modified from Surlyk \& Noe-Nygaard (1991, fig. 3); subsequent work has shown that the lower and upper SI units pass laterally into clinoform-bedded sandstones of the Fynselv and Straight River Members, respectively (see text for further discussion). (b) Schematic N-S stratigraphic section showing the inferred stratigraphic relationships between the shelf and slope/basin components of the Raukelv Formation and associated formations. Note the distal, shelf-edge position of the Rauk Plateau Member. Modified after Surlyk \& Noe-Nygaard (2005, fig. 3). 
unconformity, where high-angle clinoform-bedded, cross-bedded pebbly and massive sandstones of the Rauk Plateau Member are overlain by mudstones and siltstones of the Crinoid Bjerg Member (Hesteelv Formation), and higher up the erosional relief by richly fossiliferous pebbly sandstones and massive sandstones of the Muslingeelv Member at the top of the Hesteelv Formation.

Distribution. The Raukelv Formation forms the top plateau in southernmost Jameson Land (Figs 1, 2a).

Chronostratigraphy. Volgian. The lower part of the formation has yielded lower Volgian ammonites and the bivalve Buchia mosquensis. The bulk of the formation is of middle Volgian age and contains abundant ammonites. Erosional remnants below the top unconformity contain rare upper Volgian ammonites.

Subdivision. The formation is subdivided (from below) into the Sjællandselv, Salix Dal, Langelandselv, Prasino, Fynselv, Kokkino, Straight River and Rauk Plateau Members. As noted under the Hareelv Formation, the provisional transfer of the Sjællandselv and Salix Dal Members by Surlyk (2003) is not formalised here. These members are retained in the Raukelv Formation as originally defined by Surlyk et al. (1973).

With the exception of the Sjællandselv and Salix Dal Members at the base of the formation, the remaining members relate to the subdivision of Surlyk \& NoeNygaard (1991) based on a facies classification and sequential key surfaces. The main facies types - SB sand bank, SD sand dunes, SS sand sheet and SI siltstone were numbered in ascending order as e.g. SB1, SB2..., SD1, SD2.... etc., and their tops, which are omission surfaces, as O-SB1, O-SB2.... etc. (Fig. 56a). The latter figure (Surlyk \& Noe-Nygaard 1991, fig. 3) is reproduced here since this depicted the stratigraphic relationships that formed the basis for the original definitions. Subsequent work has shown, however, that the silty mudstone (SI) units are less persistent than depicted and are only locally developed, representing bottomsets and basinal facies deposited in front of prograding clinoforms (Fig. 56b).

Key references. Aldinger (1935), Surlyk et al. (1973, 1975, 1993, 2003), Surlyk \& Noe-Nygaard (1991, 1995, 2005).

\section{Sjoellandselv Member \\ revised member}

History. This unit was erected by Surlyk et al. (1973) as the lower member of the Raukelv Formation.

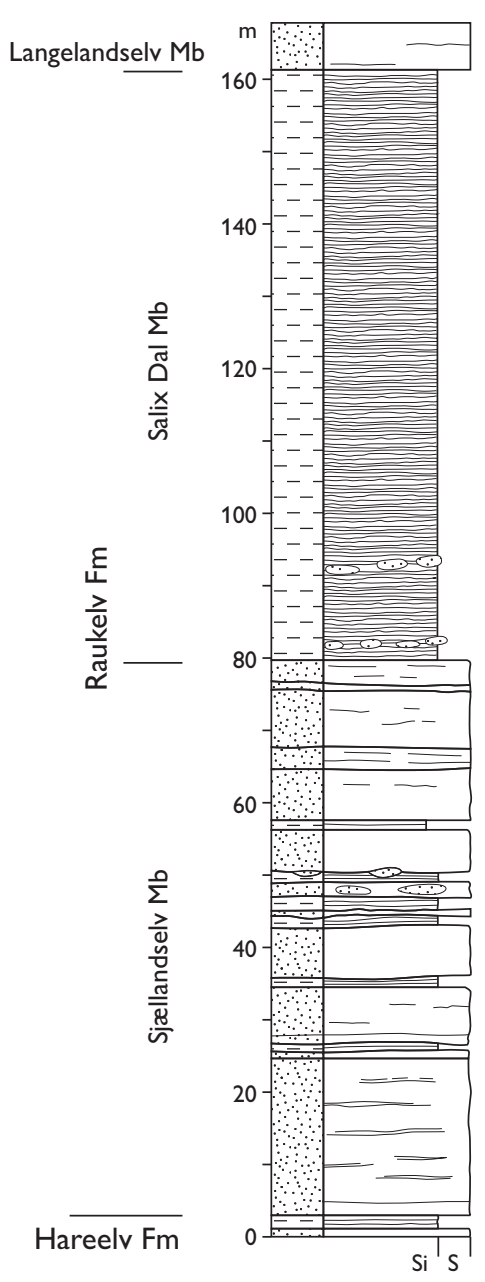

Fig. 57 Type sections of the Sjællandselv and Salix Dal Members, Raukelv Formation, Salix Dal, Jameson Land (Figs 1, 2a). Modified from Surlyk et al. (1973, fig. 31b). For legend, see Fig. 7.

Type section. Sjællandselv, $70^{\circ} 42.8^{\prime} \mathrm{N}, 23^{\circ} 23.3^{\prime} \mathrm{W}$ (Surlyk et al. 1973, fig. 31 b, section 14; Figs 2a, 57).

Thickness. Probably up to $100 \mathrm{~m}$ thick.

Lithology. Massive sandstones, typically sheet-like, with scattered mudstone clasts up to about $0.5 \mathrm{~m}$ in length. Thin mudstone interbeds occur in the lower part.

Fossils. Rare ammonites and bivalves.

Depositional environment. Slope, base-of-slope and basin in front of clinoform-bedded shelf-margin wedges. The slope sandstones interdigitate with the shelf-margin wedges (Figs 56b, 58).

Boundaries. The boundaries of the Sjællandselv Member are highly complex as the member represents a fringe of structureless gravity-flow sands shed from the collapsed front of successive shelf-margin clinoform beds 


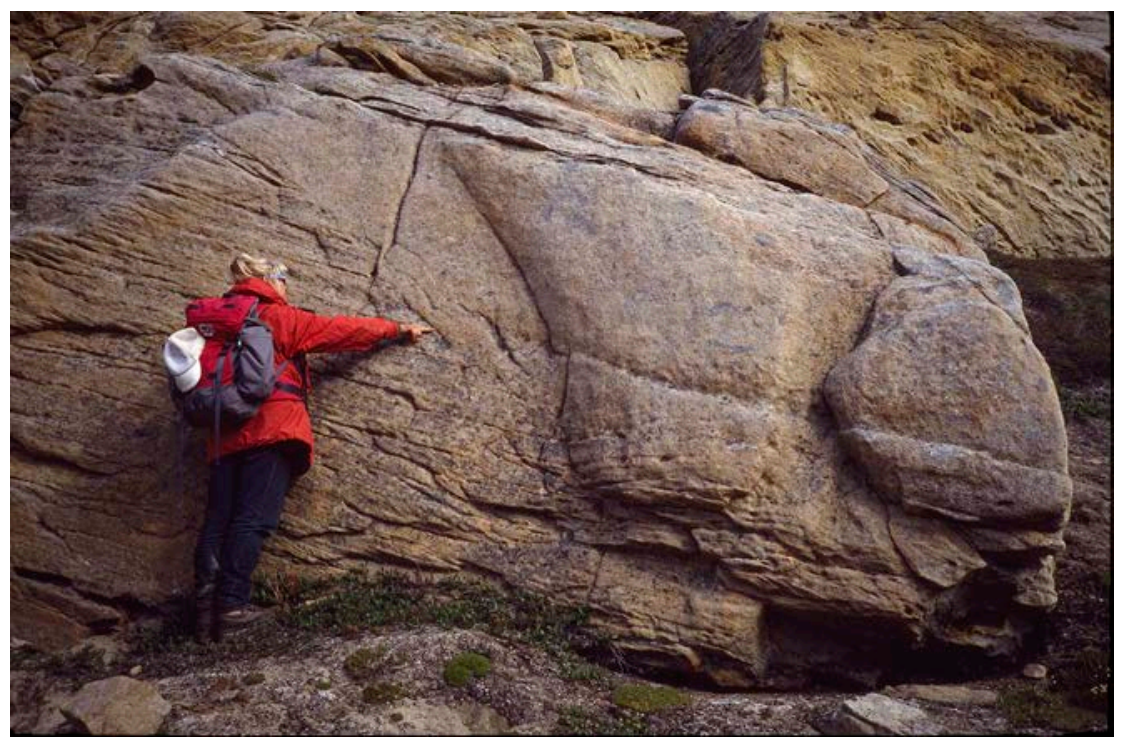

Fig. 58 Person indicating the boundary between well-structured sandstones of the Fynselv Member to the left and structureless, slumped sandstones to the right. The structureless sandstones represent the up-slope feather-edge of the basinal Sjællandselv Member sandstones, formed by collapse of the clinoform front at the shelf edge. NW-oriented branch of the Muslingeelv river, southern Jameson Land (Figs 1, 2a).

of the Raukelv Formation (Fig. 56b). The lower boundary is placed where the sandstone/mudstone ratio changes from about 50\% in the Hareelv Formation to about 90\% in the Sjællandselv Member, where the sand injectites characterising the Hareelv Formation disappear, and where the extremely irregular outcrop topography and lack of bedded sandstones in the Hareelv Formation are replaced by sheet-like sandstones of the Sjællandselv Member. Upslope, the Sjællandselv Member interfingers laterally with shelf-margin clinoform beds (Figs 56b, 58). The upper boundary in the type section is placed where dark mudstones referred to the Salix Dal Member abruptly overlie parallel-bedded massive sandstones. In southern Jameson Land, this boundary is strongly diachronous and is placed where the member underlies or onlaps the front of the clinoform-bedded members of the Raukelv Formation. In the extreme south-eastern outcrop area, the Sjællandselv Member is locally overlain, at an erosional unconformity, by the Hesteelv Formation.

Distribution. Southern Jameson Land.

Chronostratigraphy. Volgian, based on ammonites and dinoflagellate cysts.

\section{Salix Dal Member}

revised member

History. Erected by Surlyk et al. (1973) as the second member from below of the Raukelv Formation.
Type section. Sjællandselv, southern Jameson Land, $70^{\circ} 40.8^{\prime} \mathrm{N}, 23^{\circ} 23.4^{\prime} \mathrm{W}$ (Surlyk et al. 1973, fig. 31b, section 14; Figs 1, 2a, 57).

Thickness. Up to about $80 \mathrm{~m}$, wedges out towards the north and north-east.

Lithology. Dark micaceous silty and sandy mudstones with mainly thin sandy turbidites. Slump folds ubiquitous.

Fossils. Rare ammonites, dinoflagellate cysts.

Depositional environment. Slope, base-of-slope and basin.

Boundaries. The lower boundary is placed at the base of dark mudstones, overlying massive sandstones of the Sjællandselv Member. In the type section, the upper boundary is placed at the base of the lowermost coarsegrained clinoform or cross-bedded sandstone bed of the Langelandselv Member. The Salix Dal Member is interpreted to be succeeded by younger sandstone members of the Raukelv Formation farther basinward, but such relationships are not observed at outcrop.

Distribution. South-western Jameson Land (Fig. 1).

Chronostratigraphy. Volgian, based on ammonites and dinoflagellate cysts. 

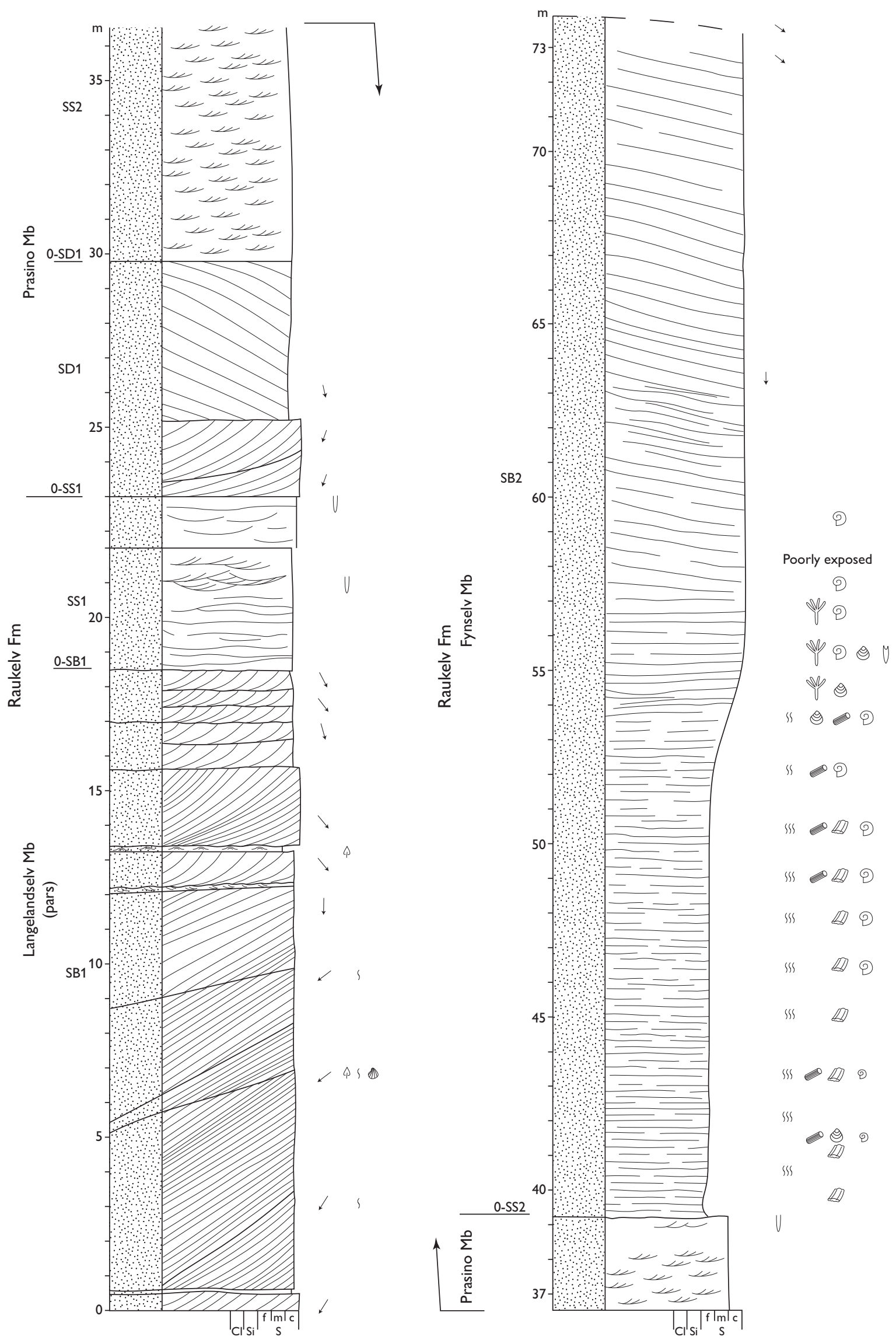

Fig. 59 Type sections of the Langelandselv and Prasino Members and reference section of the Fynselv Member, Langelandselv, SW Jameson Land (Figs 1, 2a). For legend, see Fig. 7. 

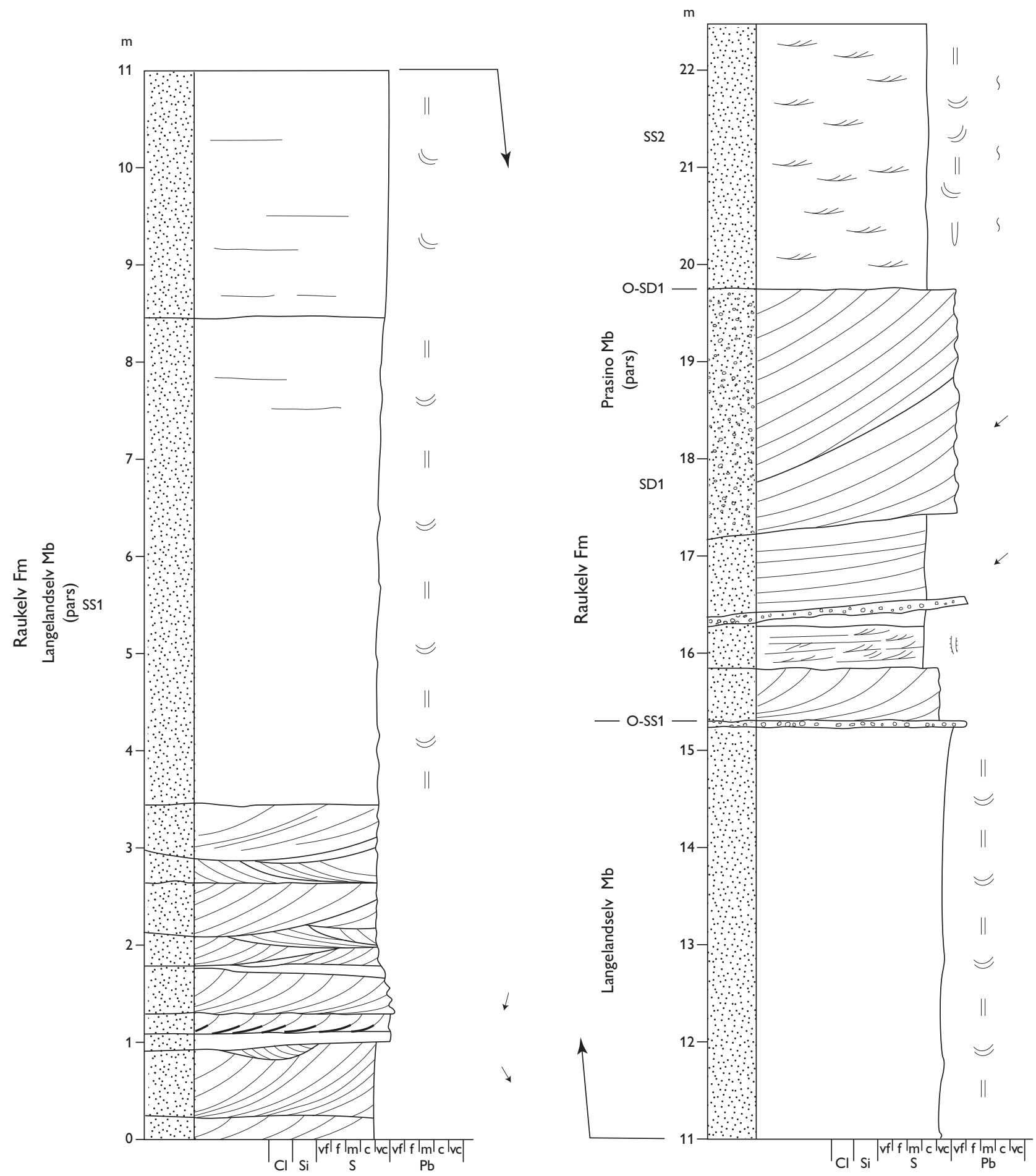

Fig. 60 Reference sections of the Langelandselv and Prasino Members. West side of the upper reaches of the Langelandselv river, southern Jameson Land (Figs 1, 2a). For legend, see Fig. 7.

\section{Langelandselv Member new member}

Name. After the Langelandselv river in southernmost Jameson Land, where the member is well exposed (Fig. 2a).
Type section. West side of the upper reaches of the Langelandselv river, south-west Jameson Land, $70^{\circ} 35.2^{\prime} \mathrm{N}$, $23^{\circ} 23.0^{\prime} \mathrm{W}$ (Figs 1, 2a, 59).

Reference section. West side of the upper reaches of the Langelandselv river, a few hundred metres north of the type section (Fig. 60). 
Thickness. Maximum thickness is about $20 \mathrm{~m}$.

Lithology. Coarse-grained, commonly pebbly sandstone. The basal unit, a high-angle clinoform bed (SB1) with cross-bedded intrasets and abundant internal truncation surfaces, is overlain by a trough cross-bedded, strongly burrowed sandstone unit (SS1), capped by a regional transgressive surface of erosion (O-SS1; Figs $56 a, 59,60)$.

Fossils. Ammonites, bivalves, crinoids, trace fossils, plant and wood fragments.

Depositional environment. South-eastward prograding shelf-margin wedge followed by shallow marine shoreface.

Boundaries. The lower boundary is not exposed at outcrop but the member is inferred to overlie massive sandstones with minor thin, black mudstones of the Sjællandselv Member or black mudstones with thin sandstones of the Salix Dal Member. The upper boundary is placed at a marked omission surface (O-SS1) at the base of the lowermost large-scale cross-bedded sandstone bed (SD1) of the Prasino Member.

Distribution. Probably the same as the formation but the member is only exposed in the western part of the outcrop area of the formation.

Chronostratigraphy. Lower - lower middle Volgian, based on ammonites and bivalves.

\section{Prasino Member}

new member

Name. After the Greek word for 'green', reflecting the colour, especially of the upper part of the member in many outcrops.

Type section. West side of the upper reaches of the Langelandselv river, same as type section of the Langelandselv Member, $70^{\circ} 35.2^{\prime} \mathrm{N}, 23^{\circ} 23.0^{\prime} \mathrm{W}$ (Figs 2a, 59).

Reference sections. Western branch of the Fynselv river (Fig. 61) and west flank of the Langelandselv river (Figs $2 a, 60)$.

Thickness. Maximum thickness estimated at about $25 \mathrm{~m}$.

Lithology. The member comprises a lower unit of coarsegrained, large-scale cross-bedded sandstone (SD1), capped by an omission surface (O-SD1; Figs 62-64),

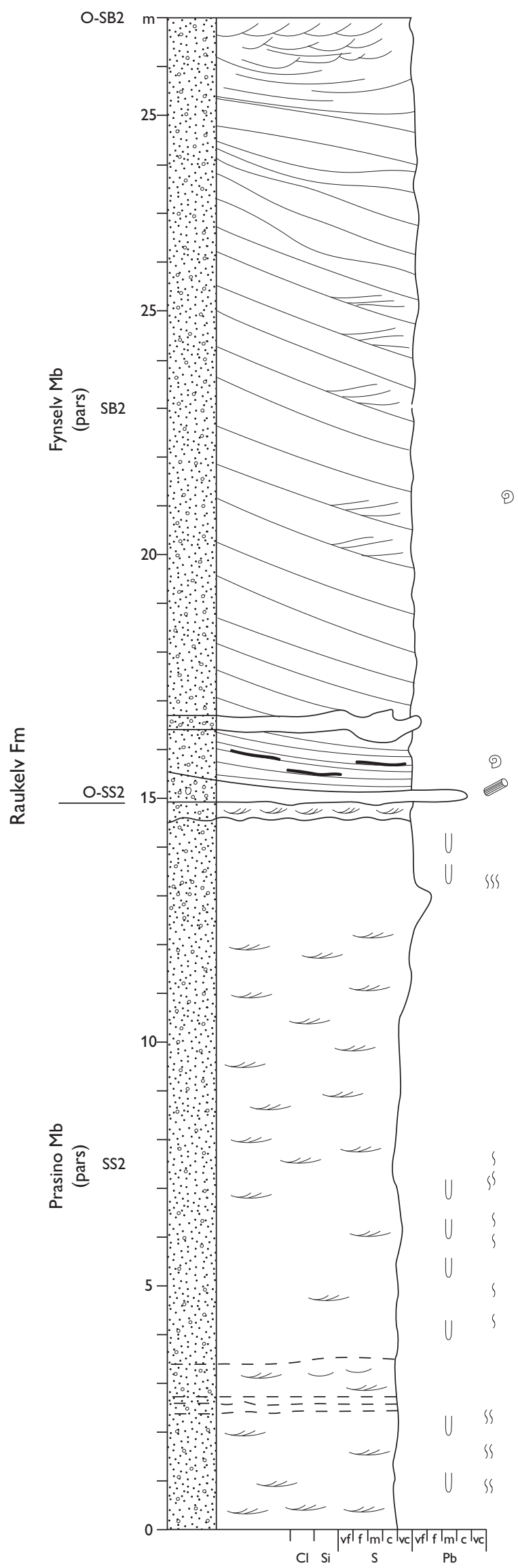

Fig. 61 Reference sections of the Prasino and Fynselv Members. West branch of the Fynselv river, southern Jameson Land (Figs 1, 2a). For legend, see Fig. 7. 

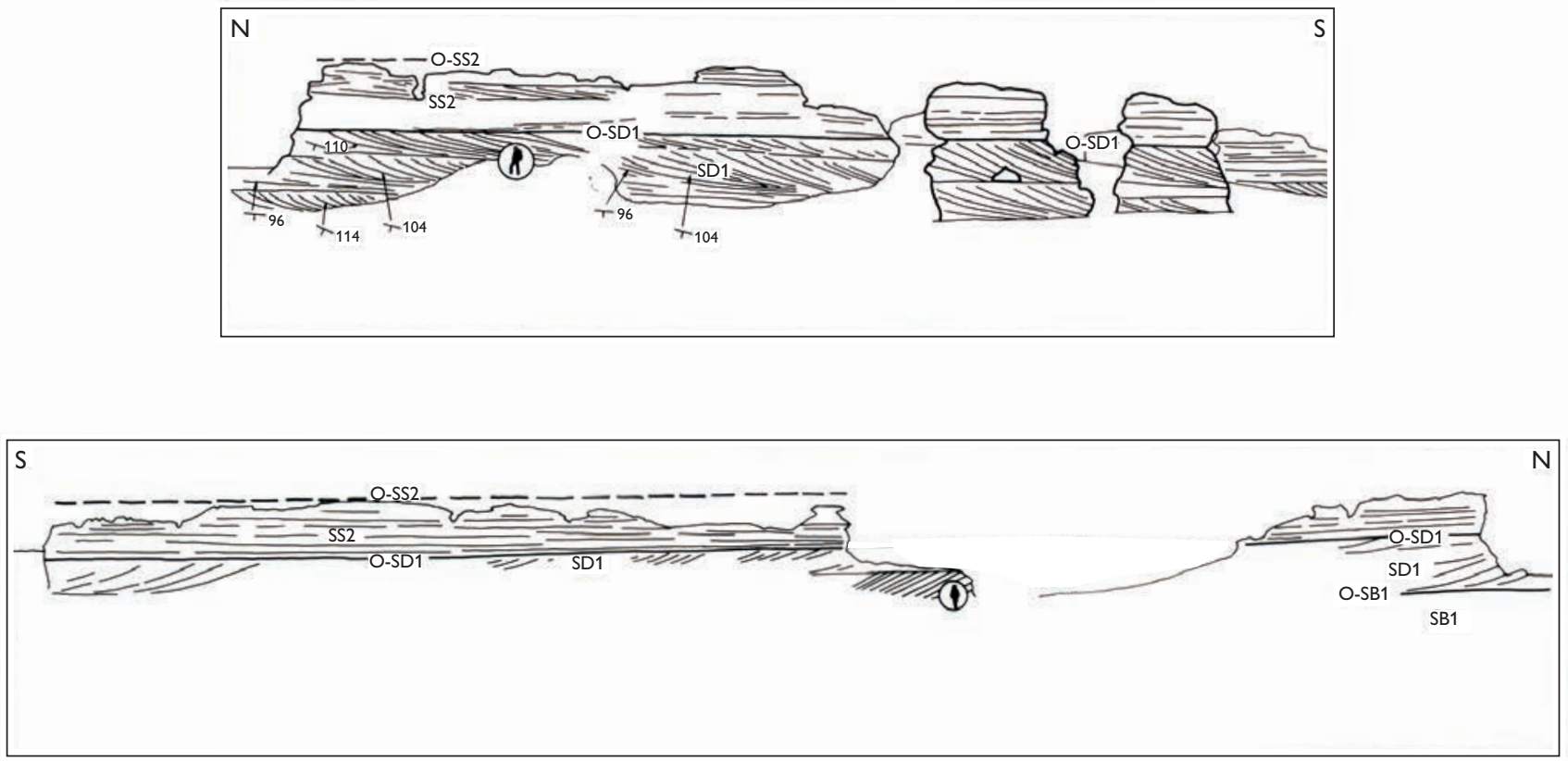

Fig. 62 Line drawings from field photographs of the Prasino Member, showing the large-scale cross-bedded lower part of the Prasino Member (SD1) overlain by low-angle trough cross-bedded and strongly burrowed bed (SS2), Raukelv Formation (see Fig. 56). Plateau east of the western branch of the Fynselv river, southern Jameson Land (Figs 1, 2a). The upper transect is modified after Surlyk \& Noe-Nygaard (1991, fig 13).
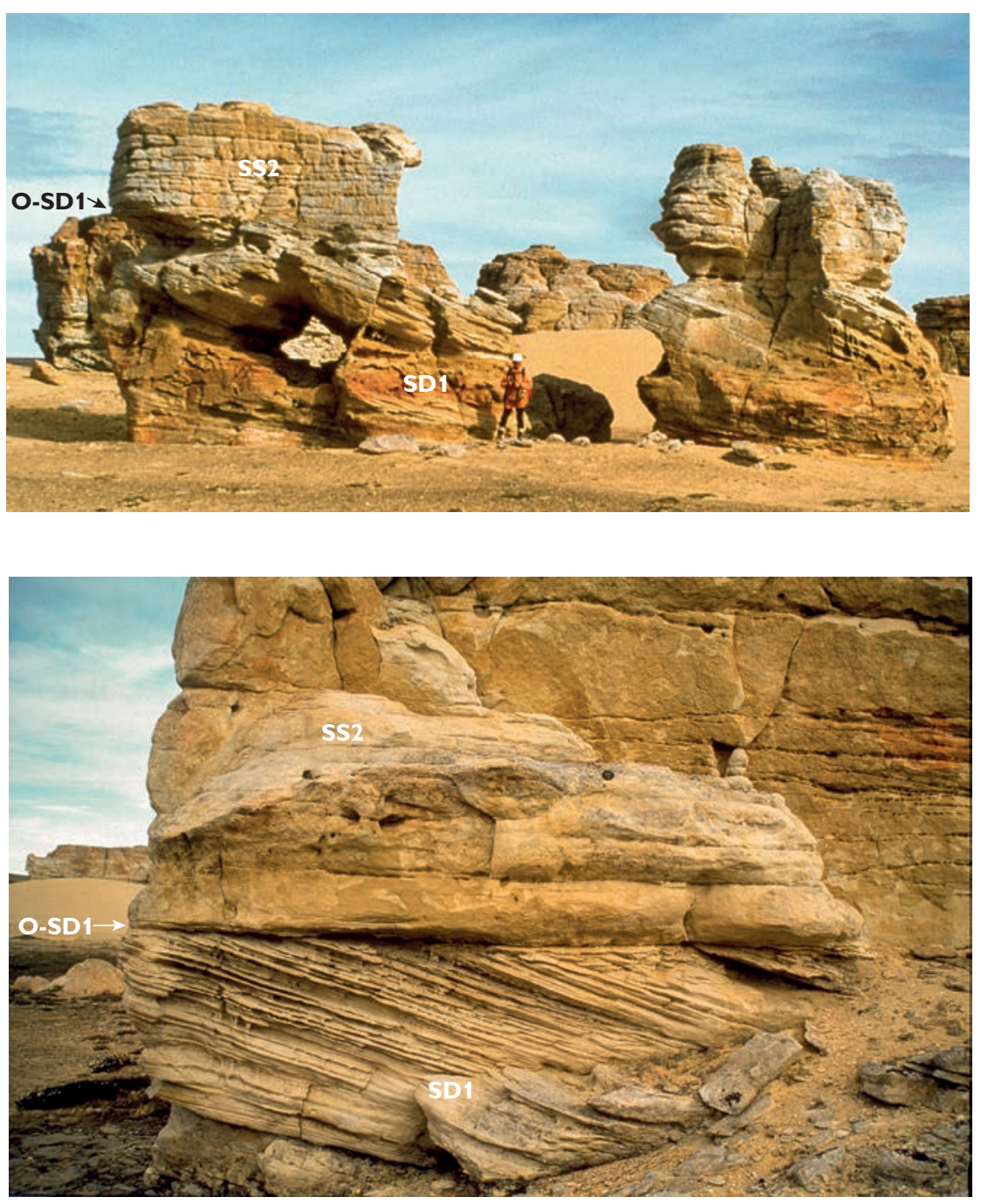

Fig. 63 Large-scale cross-bedded lower part of the Prasino Member (SD1) overlain by low-angle trough cross-bedded and strongly burrowed bed (SS2), Raukelv Formation (see Fig. 56). Plateau east of the western branch of the Fynselv river, southern Jameson Land (Figs 1, 2a).

Fig. 64 Close-up of section shown in Fig. 63 showing large-scale cross-bedded sandstones (SD1) with tidal bundles, overlain by trough cross-bedded and burrowed sandstones (SS2) of the Prasino Member, Raukelv Formation (see Fig. 56). Plateau east of the western branch of the Fynselv river, southern Jameson Land Land (Figs 1, 2a). 
overlain by greenish, coarse-grained, commonly pebbly sandstone showing poorly preserved trough cross-lamination (SS2), capped by an omission surface (O-SS2). This part of the member (SS2) is a highly variable, mainly loose and poorly exposed unit composed of coarsegrained, trough cross-bedded sandstone, commonly green in colour (this facies is not shown in Surlyk \& NoeNygaard 1991, fig. 3; Fig. 56a).

Fossils. Ammonites, bivalves, logs and trace fossils, including the metre-long U-burrows of Tisoa habichi, mainly in the upper part.

Depositional environment. Shallow marine, tidal sandwave fields and offshore marine.

Boundaries. The lower boundary (O-SS1) is placed at the base of large-scale trough cross-bedded sandstone of SD1, overlying mainly cross-laminated, strongly bioturbated and diffusely bedded sandstone of SS1. The upper boundary is an important omission surface (O-SS2), placed at the base of a thick high-angle clinoform-bedded sandstone (SB2) or at the base of a siltstone unit (SI) that in a few areas forms the lower part of a coarsening-upwards succession passing upwards into the clinoform bed of SB2 (Fig. 59).

Distribution. Exposed in the northern outcrop areas of the formation but appears to have wedged out towards the east.

Chronostratigraphy. Middle Volgian.

\section{Fynselv Member}

revised member

History. The member is revised here from that defined by Surlyk et al. (1973) to include only the main plateau-forming lower clinoform bed of the original Fynselv Member (bed D of Surlyk et al. 1973, denoted SB2 in Surlyk \& Noe-Nygaard 1991; Fig 56a). The lower part of the original Fynselv Member is here referred to the new Langelandselv and Prasino Members. The upper part of the original member is here referred to the new Kokkino, Straight River and Rauk Plateau Members.

Type area. Eastern branch of the Fynselv river and the adjacent western plateau, southern Jameson Land (Figs $1,2 a)$.

Reference sections. Western branch of the upper reach of Langelandselv (Fig. 2a); same as type sections for the

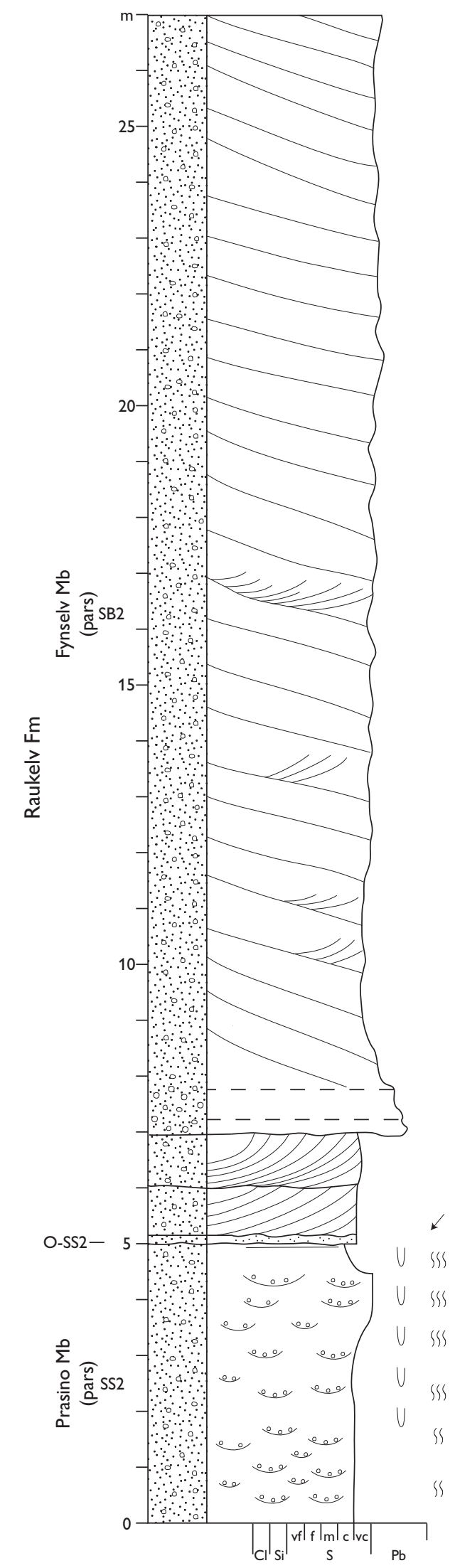

Fig. 65 Reference section of the Fynselv Member (SB2 in Surlyk \& Noe-Nygaard 1991). Eastern branch of the Fynselv river, Jameson Land (Figs 1, 2a). For legend, see Fig. 7. 

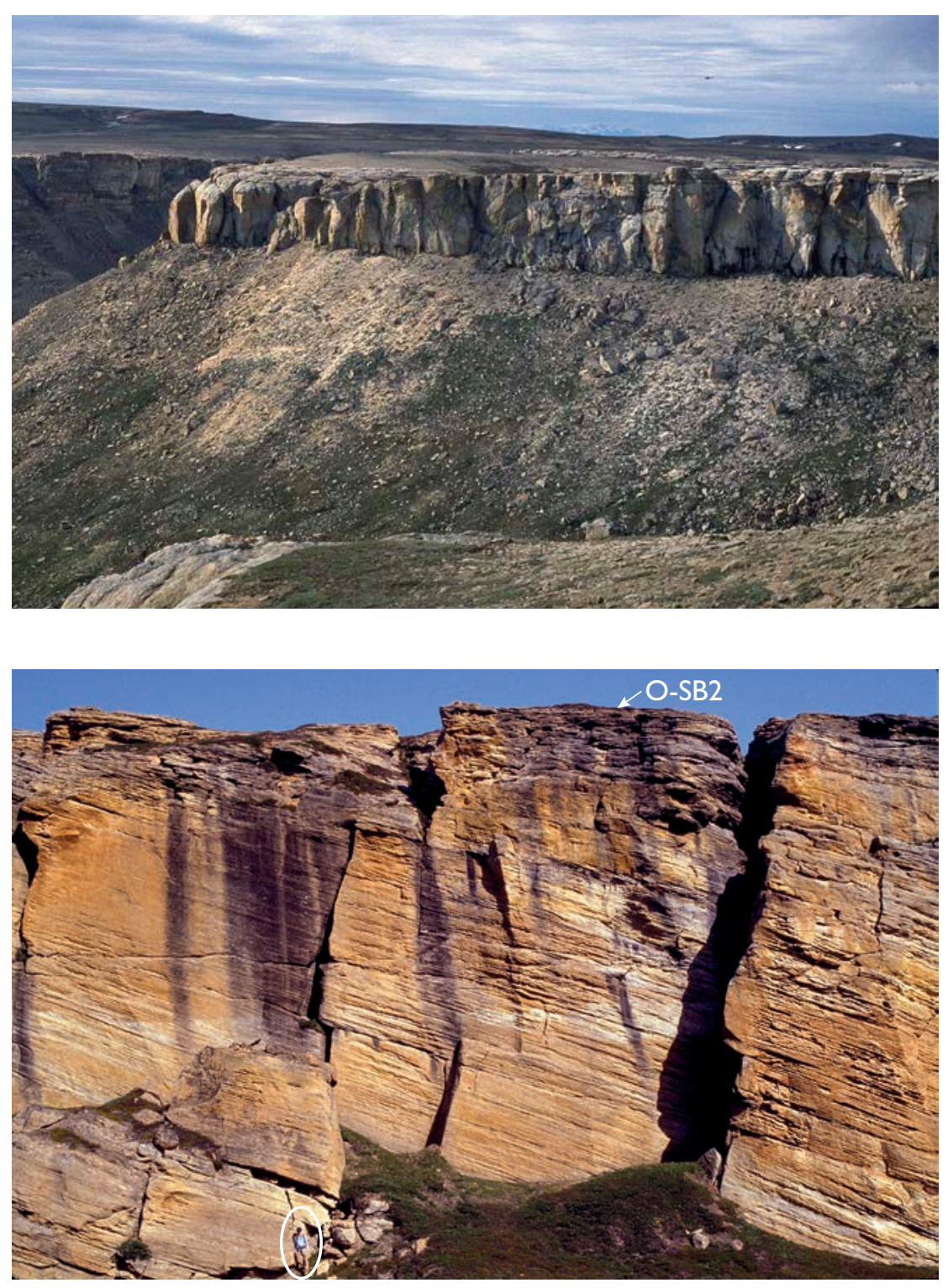

Fig. 66 The plateau-forming high-angle clinoform bed of the Fynselv Member ( $c$. $30 \mathrm{~m}$ thick), showing a typical example of the outcrop of this landscape-forming unit. This bed can be traced over $900 \mathrm{~km}^{2}$ and reaches thicknesses of up to $50 \mathrm{~m}$. Western branch of the Fynselv river, southern Jameson Land (Figs 1, 2a), viewed looking west.
Fig. 67 The Fynselv Member showing large-scale clinoform bedding with asymptotic topsets creating sigmoidal clinothems, capped by an omission surface (O-SB2, see Fig. 56), Raukelv Formation, southern Jameson Land (Figs 1, 2a). Person (encircled) for scale.
Langelandselv and Prasino Members (Fig. 59), west bank of Fynselv (Figs 2a, 61, 65).

Thickness. Maximum thickness about $50 \mathrm{~m}$, but difficult to estimate as the member forms the top plateau in the main outcrop area (Fig. 66).

Lithology. Very coarse-grained, pebbly, plateau-forming sandstone showing high-angle $\left(\sim 25^{\circ}\right)$ mainly sigmoidal clinoform bedding (SB2, in Surlyk \& Noe-Nygaard 1991; Figs 56a, 67). It differs from the other high-angle clinoform-bedded members in its greater thickness, uniformity, great lateral extent (mapped over $900 \mathrm{~km}^{2}$ ), abundance of bivalves, and especially in the regular, mainly sigmoidal nature of the clinoforms, in some cases with a relatively thick topset. Although the clinoforms of the Fynselv Member may locally be truncated and tangential, the other clinoform-bedded members characteristically show tangential clinoforms throughout, commonly with internal erosional reactivation surfaces. Slump scars, draped by massive sandstones, are present locally in the Fynselv Member (Fig. 58).

Fossils. Ammonites (Pavlovia, Dorsoplanites), bivalves (Camptonectes, Entolium, Astarte, Isocyprina), crinoids, wood, large plant fragments and trace fossils, including Curvolithos and Tisoa habichi.

Depositional environment. Eastward prograding shelf-margin wedge. 
Boundaries. The lower boundary is placed at the base of a thick, laterally extensive high-angle clinoform-bedded sandstone (SB2), overlying greenish, very coarse-grained pebbly sandstones of the upper Prasino Member (SS2) at a sharp surface (O-SS2). In western outcrops, in the Langelandselv area, the boundary is placed at the sharp base (O-SS2) of an up to $14 \mathrm{~m}$ thick strongly burrowed siltstone which coarsens gradationally upwards into the clinoform bed of SB2 (Fig. 59; lower 'Sl' unit in Fig. 56a). The upper boundary is placed at the base of the lowest strongly bioturbated and cross-bedded sandstone (SS3) at a marked omission surface (O-SB2), forming the topographic top surface of the main central plateau in the outcrop area (Figs 56a, 67).

Distribution. Same as the formation except for the eastern areas where it has been removed by modern erosion.

Chronostratigraphy. Middle Volgian, based on ammonites and bivalves.

\section{Kokkino Member \\ new member}

History. The member was included in the upper part of the Fynselv Member of Surlyk et al. (1973) and corresponds to the SS3, SD2 and SB3 units of Surlyk \& NoeNygaard (1991) (Fig. 56a).

Name. After the Greek word for 'red', reflecting the commonly red colour of the top part of the member in outcrop.

Type section. Ridge on the east side of the eastern branch of the Fynselv river (Figs 2a, 68), position somewhat uncertain.

Thickness. Maximum thickness estimated at about $40 \mathrm{~m}$.

Lithology. Medium and coarse-grained, trough cross-bedded burrowed, commonly pebbly, sandstones (SS3), overlain by cross-bedded tidally influenced sandstones (SD2), and high-angle clinoform-bedded sandstone (SB3). The clinoforms are tangential or rarely sigmoidal and the clinothems locally show large-scale trough cross-bedded intrasets (Fig. 56a).

Fossils. Trace fossils.

Depositional environment. Shelfal sandwave fields followed by an east to south-eastward prograding clinoform-bedded shelf-margin wedge.

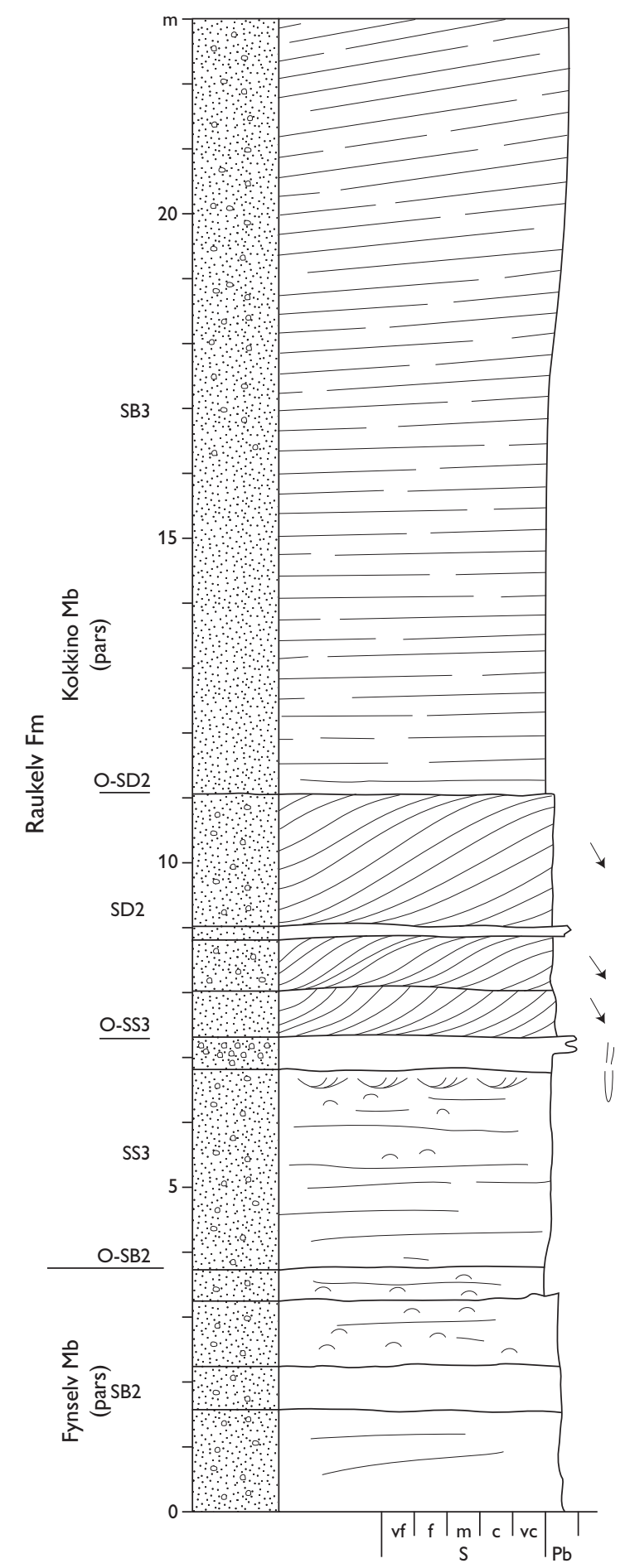

Fig. 68 Type section of the Kokkino Member (SS3, SD2, SB3 in Surlyk \& Noe-Nygaard 1991, see Fig. 56). The log shows only the gently inclined bottomset of the steep clinoform bed of SB3. Eastern branch of the Fynselv river, Jameson Land (Figs 1, 2a). For legend, see Fig. 7.

Boundaries. The lower boundary is placed at the base of the lowest cross-bedded and strongly bioturbated sandstones (SS3), overlying the omission surface (O-SB2) capping the clinoform-bedded Fynselv Member (SB2). The upper boundary is placed at the base of low-angle 
clinoform-bedded sandstones referred to the Straight River Member that abruptly overlie the high-angle clinoform-bedded sandstones of the Kokkino Member at the O-SB3 omission surface (Fig. 56a). In a few areas, the clinoform-bedded sandstones of the Straight River Member are underlain by a siltstone unit (upper SI unit in Fig. 56a) In such cases, the upper boundary is placed at the base of the siltstone, overlying the clinoform bed of the Kokkino Member at the omission surface O-SB3 (Fig. 56a).

Distribution. Probably the same as the formation, but the member has been removed by modern erosion at the western outcrop margins.

Chronostratigraphy. Probably middle Volgian.

\section{Straight River Member \\ new member}

History. The member was not known at the time when the Raukelv Formation was erected, and only in part (SD3) at the time when Surlyk \& Noe-Nygaard (1991) was published. It was thus only implicitly included in the upper part of the Fynselv Member of Surlyk et al. (1973). The part labelled SD3 in Fig. 56a is thus much thicker and replaces the underlying SI unit in most areas of exposure of the member.

Name. From Straight River (Fig. 2a), named by Aldinger (1935).

Type section. Eastern side of Straight River, southern Jameson Land, 70³0.0'N, 2307.8'W (Figs 1, 2a, 69).

Reference section. Southern part of Straight River (Figs $2 a, 70)$.

Thickness. Maximum exposed thickness estimated at about $50 \mathrm{~m}$. The base and top of the member are nowhere exposed in the same sections. The clinoform set may thus attain much greater thicknesses than indicated on Fig. 56a.

Lithology. Coarse-grained sandstones, showing lowangle (up to $7^{\circ}$ ) clinoform bedding showing large-scale cross-bedded, tidally influenced intrasets (SD3). In a few areas, the lower part of the member is composed of siltstones that pass upwards into the clinoform bed (upper SI in Fig. 56a).

Fossils. Belemnites and trace fossils.

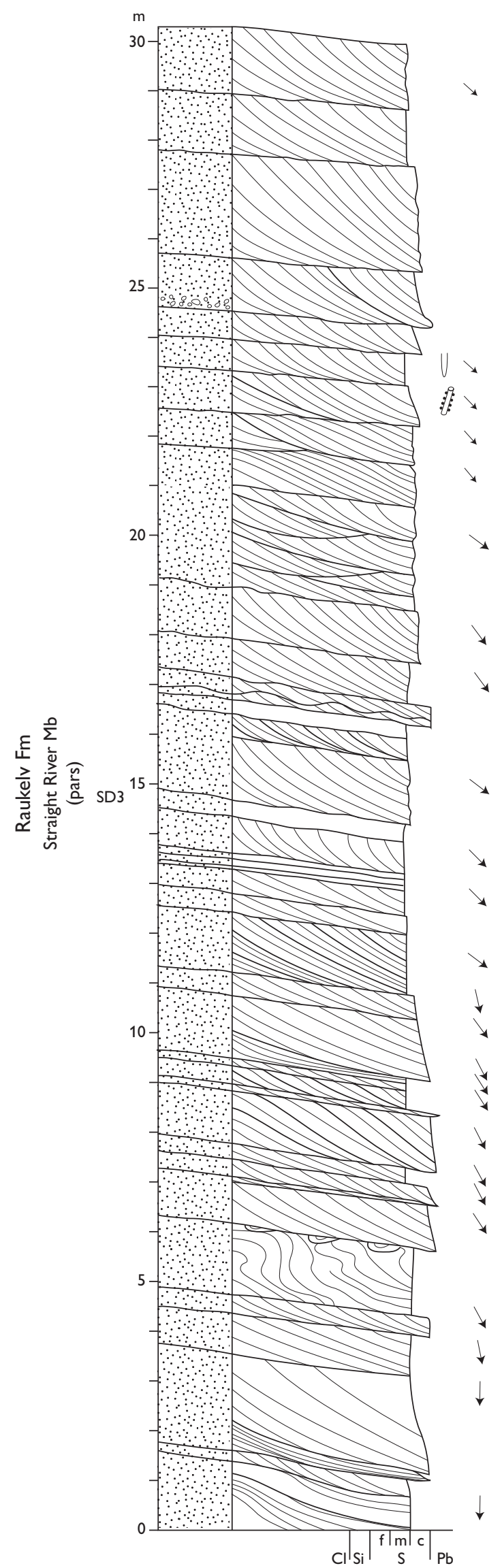

Fig. 69 Type section of the Straight River Member, Straight River, Jameson Land (Figs 1, 2a). The large-scale cross-bedded sets are intrasets in low-angle clinothems. For legend, see Fig. 7. 


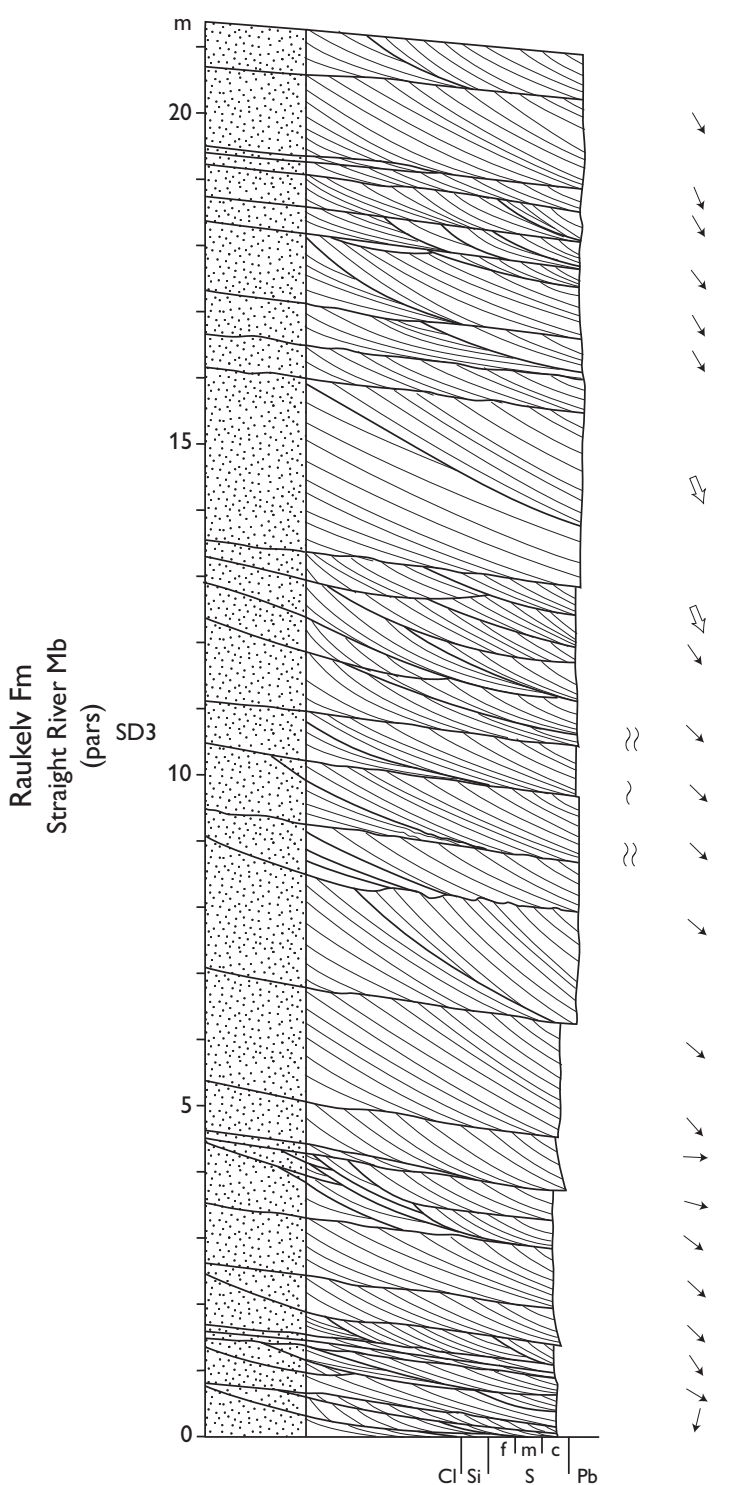

Fig. 70 Reference section of the Straight River Member, Straight River, Jameson Land (Figs 1, 2a). The large-scale cross-bedded sets are intrasets in low-angle clinothems. For legend, see Fig. 7.

Depositional environment. South-eastward prograding shelf-margin wedge.

Boundaries. The lower boundary is placed at the base of the low-angle clinoform-bedded, sandstone unit with large-scale cross-bedded intrasets, or locally at the base of a siltstone unit, abruptly overlying the high-angle clinoform bed of the Kokkino Member at a marked omission surface (O-SB3). The upper boundary (O-SD3) is placed at the base of the high-angle clinoform bed of the Rauk Plateau Member (SB4; Fig. 56a), or at the angular and erosional unconformity at the base of the Ryazanian Hesteelv Formation.
Distribution. The member is restricted to the eastern part of the outcrop area of the formation and has wedged out west of Fynselv (Fig. 2a).

Chronostratigraphy. Probably lower upper Volgian, as constrained by underlying and overlying members.

\section{Rauk Plateau Member}

new member

History. Sandstones of this member were first described by Aldinger (1935). The member formed the uppermost part of the Fynselv Member as defined by Surlyk et al. (1973). Described as SB4 by Surlyk \& Noe-Nygaard (1991).

Name. After the Rauk Plateau of Aldinger (1935, plate 2).

Type section. Between Straight River and the Raukelv river, $70^{\circ} 29.3^{\prime} \mathrm{N}, 23^{\circ} 09.2^{\prime} \mathrm{W}$ (Figs 2a, 71, 72). No logs are presented as the member only comprises one high-angle clinoform bed exposed in vertical walls.

Thickness. Maximum measured thickness is about $27 \mathrm{~m}$ (Surlyk \& Noe-Nygaard 2005).

Lithology. Coarse-grained, pebbly high-angle $\left(\sim 25^{\circ}\right)$ clinoform-bedded sandstones with large-scale cross-bedded intrasets and internal large-scale erosional reactivation surfaces (SB4; Figs 56a, 72). The clinoforms are truncated-tangential or rarely sigmoidal in areas where the top is not truncated by the base-Hesteelv Formation unconformity.

Fossils. Trace fossils, wood fragments.

Depositional environment. North-eastward prograding shelf-margin wedge.

Boundaries. The lower boundary is placed at an abrupt omission surface (O-SD3) that forms the base of the high-angle clinoform bed (SB4), overlying the low-angle, internally cross-bedded clinoform bed (SD3) of the Straight River Member. Outwith the outcrop area of the Hesteelv Formation, the upper boundary of the Rauk Plateau Member is typically the present-day top erosion surface. In a few places, however, the depositional upper boundary is preserved as an intensely bioturbated omission surface (O-SB4). In the outcrop area of the Hesteelv Formation, the upper boundary is an angular, erosional unconformity overlain by black to grey mudstones of the Crinoid Bjerg Member or, to the north, by the sandy 


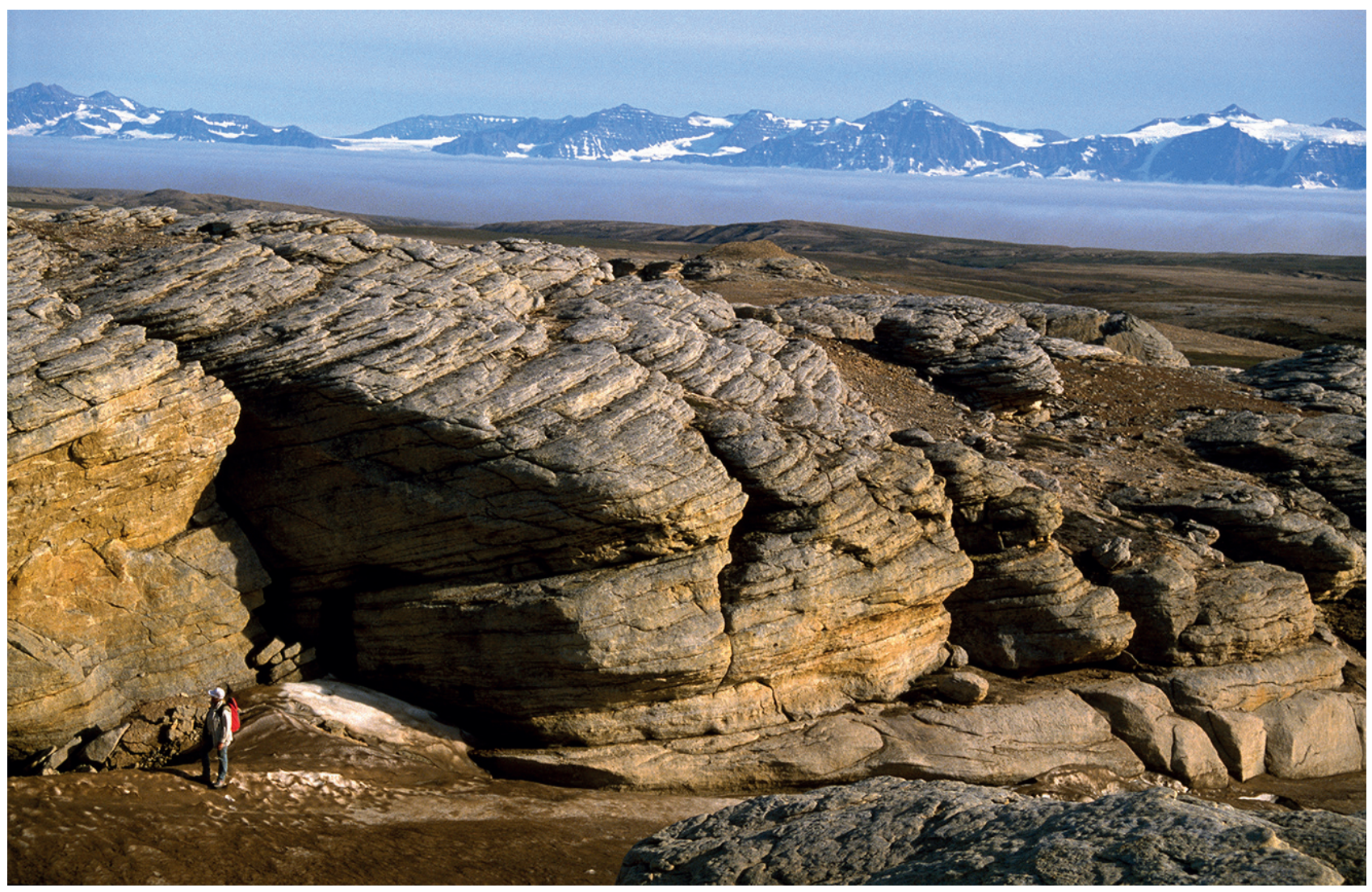

Fig. 71 Photograph of the type section of the Rauk Plateau Member, Rauk Plateau, Jameson Land, viewed towards the SSE (Figs 1 , 2a). The underlying beds are rarely shown in the same section as the member, which forms the uppermost bed in most of the area. The type section is thus shown in a photograph. Towards the east and south, the member is truncated by an erosional canyon filled in with the Hesteelv Formation. Person (lower left) for scale.

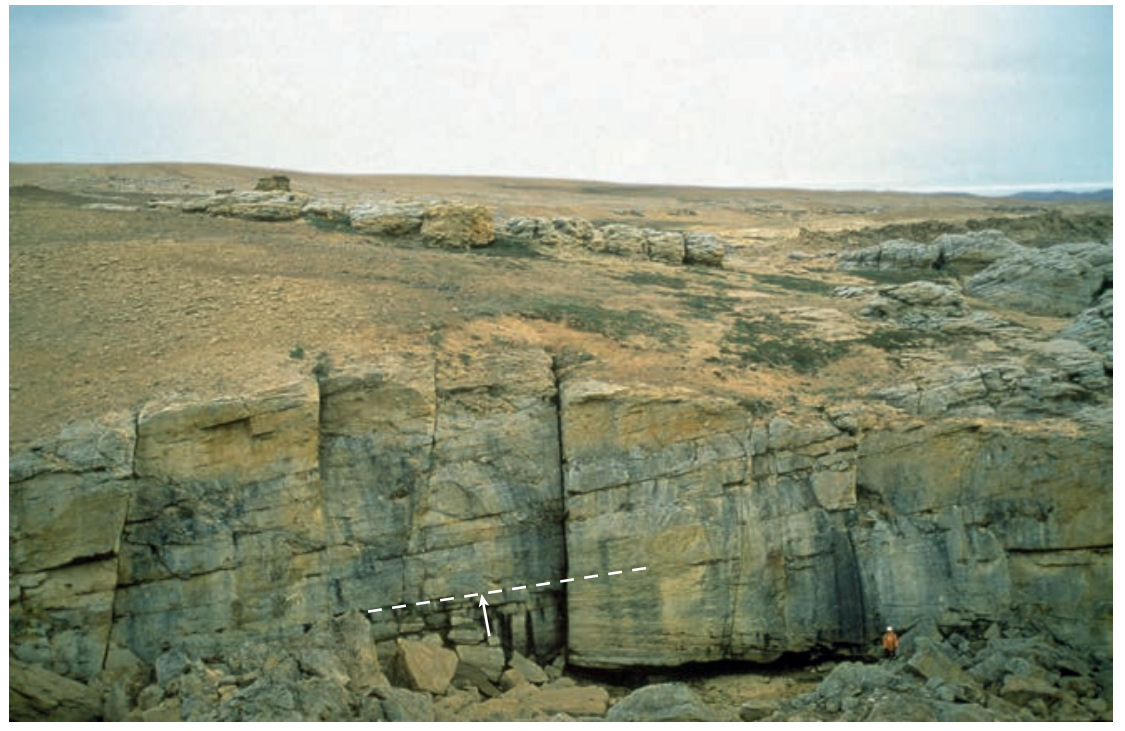

Fig. 72 Photograph of the high-angle clinoform-bedded Rauk Plateau Member. Note the internal truncation surface downlapped by younger clinoforms (arrowed). Immediately north of the type section, Rauk Plateau, southern Jameson Land (Figs 1, 2a); person (lower right) for scale. shell conglomerate of the lowermost Muslingeelv Member, both belonging to the Hesteelv Formation).

Distribution. The member is restricted to the southern and south-eastern outcrop areas of the Raukelv
Formation, but its distribution area is probably greatly reduced due to modern erosion.

Chronostratigraphy. Upper Volgian, constrained by ammonites and bivalves in underlying and overlying units. 
a

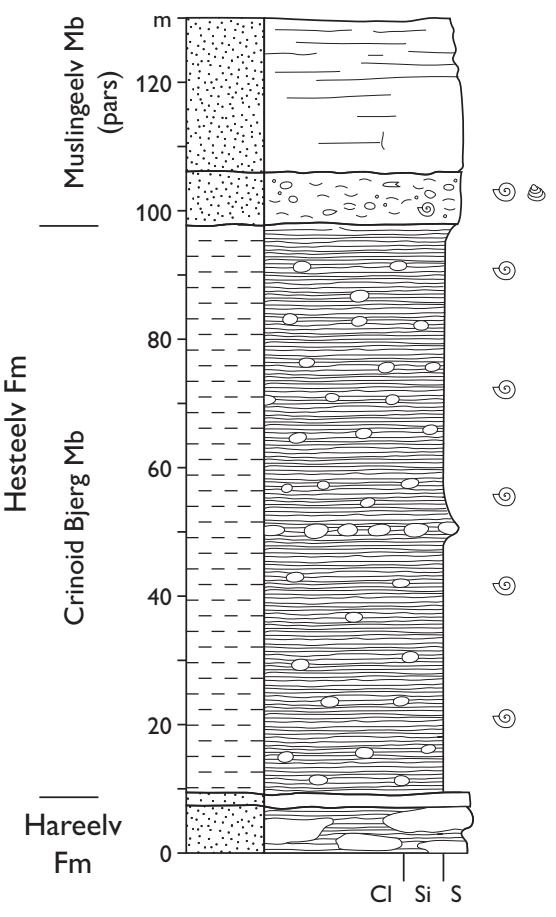

\section{Hesteelv Formation}

History. Erected by Surlyk et al. (1973) and described in more detail by Surlyk (1973).

Type section. Between the Muslingeelv and Hesteelv rivers, southern Jameson Land, $70^{\circ} 29.0^{\prime} \mathrm{N}, 23^{\circ} 02.3^{\prime} \mathrm{W}$ (Surlyk et al. 1973, fig. 36a; Surlyk 1973, fig. 7, section 6; Figs $1,2 a, 73 a)$.

\section{Thickness. 10-120 m.}

Lithology. The formation fills a c. $10 \mathrm{~km}$ wide U-shaped canyon with a southward plunging axis (Fig. 74). Black mudstones occur in the deepest part of the canyon and pass upwards into silty and sandy micaceous mudstones capped by a sandy shell conglomerate that, in the central part of the canyon, is overlain by a thin mudstone passing upwards into coarse-grained sandstone.

Fossils. Ammonites, belemnites, bivalves, crinoids, wood and trace fossils.

Depositional environment. Prograding shelf-margin canyon fill.

Boundaries. The lower boundary is placed at the base of dark mudstones of the Crinoid Bjerg Member, overlying yellow sandstones of the Rauk Plateau or Sjællandselv Members (both of the Raukelv Formation), or black,
Fig. 73 Hesteelv Formation, Hesteelv, southernmost Jameson Land (Figs 1, 2a). For legend, see Fig. 7. (a) Type sections of the Hesteelv Formation and its constituent Crinoid Bjerg and Muslingeelv Members. (Surlyk et al. 1973, fig. 36a). (b) Reference section of the Muslingeelv Member (Surlyk et al. 1973, fig. 36b).

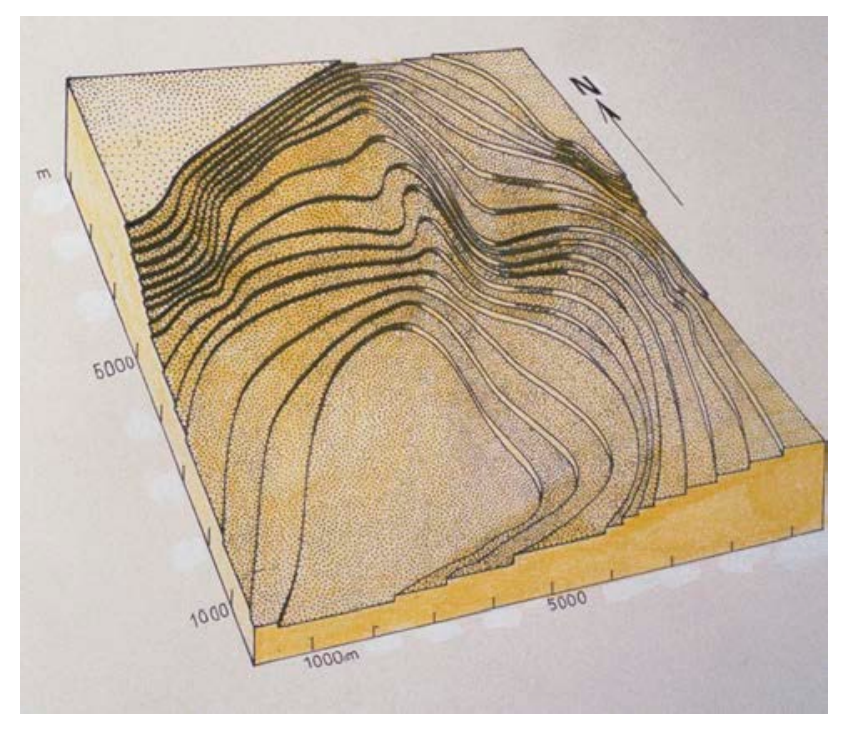

Fig. 74 Contoured block diagram of a major erosional canyon incised in the SE margin of the prograding Rauk Plateau Member and subsequently filled with the upwards-coarsening Hesteelv Formation. Several fluvial tributaries lead to the margin of the canyon. Rauk Plateau, southernmost Jameson Land (Figs 1, 2a).

well-laminated mudstones of the Hareelv Formation in a small area to the south-east (Fig. 73a). The boundary is an angular, erosional unconformity, representing the floor of the U-shaped canyon. The top of the formation is the modern erosion surface. 
Distribution. Southernmost Jameson Land (Figs 1, 2a).

Chronostratigraphy. Ryazanian (lowermost Cretaceous), Praetollia maynci and Hectoroceras kochi ammonite zones.

Subdivision. Subdivided from below into the Crinoid Bjerg and Muslingeelv Members.

Key references. Aldinger (1935), Spath (1947), Surlyk et al. (1973), Surlyk (1973, 2003), Surlyk \& Noe-Nygaard (2005).

\section{Crinoid Bjerg Member}

History. Erected by Surlyk et al. (1973) and described in more detail by Surlyk (1973).

Type section. North-eastern slope of the Crinoid Bjerg mountain, $70^{\circ} 29.7^{\prime} \mathrm{N}, 23^{\circ} 04.0^{\prime} \mathrm{W}$ (Figs 2a, 73a).

Thickness. Maximum measured thickness of $85 \mathrm{~m}$ in the deepest part of the canyon, wedging out at the margins.

Lithology. Black laminated mudstones in the deepest part of the canyon which cuts through the Raukelv Formation into the top of the Hareelv Formation (Fig. 73a). This facies grades upwards and laterally into silty and sandy mudstones.

Fossils. Ammonites, belemnites, crinoids, wood and plant debris, trace fossils.

Depositional environment. Prograding shelf-margin canyon fill.

Boundaries. Lower boundary same as the formation. The upper boundary is placed at the base of the lowest highly fossiliferous sandstone bed of the Muslingeelv Member.

Distribution. Same as the formation.

Chronostratigraphy. Ryazanian, Praetollia maynci and Hectoroceras kochi ammonite zones.

\section{Muslingeelv Member}

History. Erected by Surlyk et al. (1973) and described in more detail by Surlyk (1973).

Type section. North-east slope of the mountain of Crinoid Bjerg, immediately west of Muslingeelv $70^{\circ} 29.7^{\prime} \mathrm{N}$, 2304.0'W (Surlyk et al. 1973, fig. 36a; Figs 2a, 73a).
Reference section. North-east slope of the mount of Crinoid Bjerg (Surlyk et al. 1973, fig. 36b) (Fig. 73b).

Thickness. 10-35 m.

Lithology. The basal unit of fossiliferous, commonly pebbly sandstones is overlain by massive or cross-bedded sandstones. In the western part of the canyon fill, the fossiliferous beds are succeeded by thin mudstones followed by massive or large-scale cross-bedded sandstones.

Fossils. Ammonites, bivalves, belemnites, wood, trace fossils.

Depositional environment. Shelf-margin canyon fill.

Boundaries. The lower boundary is placed at the base of the lowest fossiliferous pebbly sandstone bed, overlying silty and sandy mudstones of the Crinoid Bjerg Member or locally the Raukelv Formation. The member forms the uppermost unit in the area, so the nature of the original upper boundary is not known.

Distribution. Same as the formation.

Chronostratigraphy. Ryazanian, Hectoroceras kochi ammonite zone.

\section{Hall Bredning Group \\ new group}

History. Erected here to include the mainly Upper Jurassic mudstone-dominated part of the Jurassic succession on the east coast of Milne Land, representing the Milne Land Subbasin.

Name. After Hall Bredning, that part of the Scoresby Sund fjord, which borders eastern Milne Land (Fig. 1).

Type area. Eastern Milne Land (Figs 1, 2b).

Thickness. Up to about $1200 \mathrm{~m}$.

Lithology. The lower part of the group is dominated by conglomerates and coarse-grained sandstones, onlapping a south-eastward inclined crystalline basement surface. The middle part is dominated by black mudstones and dark grey silty mudstones with intercalated sandstones in some members. The upper part marks a return to fine- to coarse-grained sandstones. 
Fossils. Ammonites, belemnites, corals, the bivalve Buchia, and rich bivalve faunas in some coarser-grained units, dinoflagellate cysts, plant fragments and trace fossils.

Depositional environment. Marine rocky shoreline at the base, followed by middle and lower shoreface, offshore transition zone and offshore, returning to shoreface and shelf-margin wedge, and topped by shoreface and paralic sediments.

Boundaries. Unconformably overlies crystalline basement and forms the top stratum in the outcrop area in eastern Milne Land. Unconformably overlain by Palaeogene plateau basalts in the western part of the outcrop area.

Distribution. Eastern Milne Land (Fig. 1). Possibly also south-east Gåseland (Håkansson et al. 1971).

Subdivision. The group is subdivided into the Charcot Bugt, Kap Leslie, Hartz Fjeld and Pinnadal Formations.

Chronostratigraphy. Lower Bathonian - Hauterivian, based on rich ammonite faunas and dinoflagellate cysts.

Key references. Aldinger (1935), Spath (1935, 1936), Håkansson et al. (1971), Callomon \& Birkelund (1980, 1982), Fürsich (1982), Fürsich \& Heinberg (1983), Birkelund et al. (1984), Birkelund \& Callomon (1985), Larsen (1995), Surlyk (2003).

\section{Charcot Bugt Formation}

History. The formation was erected by Aldinger (1935) and revised and described by Callomon \& Birkelund (1980).

Type section. Visdal, south-east Milne Land. Sections M44 $\left(70^{\circ} 39.4^{\prime} \mathrm{N}, 25^{\circ} 46.7^{\prime} \mathrm{W}\right)$ and $\mathrm{M} 49\left(70^{\circ} 41.1^{\prime} \mathrm{N}, 2^{\circ} 49.0^{\prime} \mathrm{W}\right)$ of Birkelund et al. (1984) are here designated as a combined type section (Figs 1, 2b, 75-77).

Reference sections. Parat Kløft, Kosmocerasdal and Mudderbugt (Birkelund et al. 1984, sections M1, M2 and M39, respectively; Fig. 2b).

Thickness. Up to $200 \mathrm{~m}$.

Lithology. Conglomerates with kaolinised pebbles at the base, overlain by several sets of cross-bedded and largescale high-angle clinoform-bedded sandstones that are pebbly in places.

Fossils. Rare ammonites, bivalves, corals, belemnites, plant fragments and trace fossils.

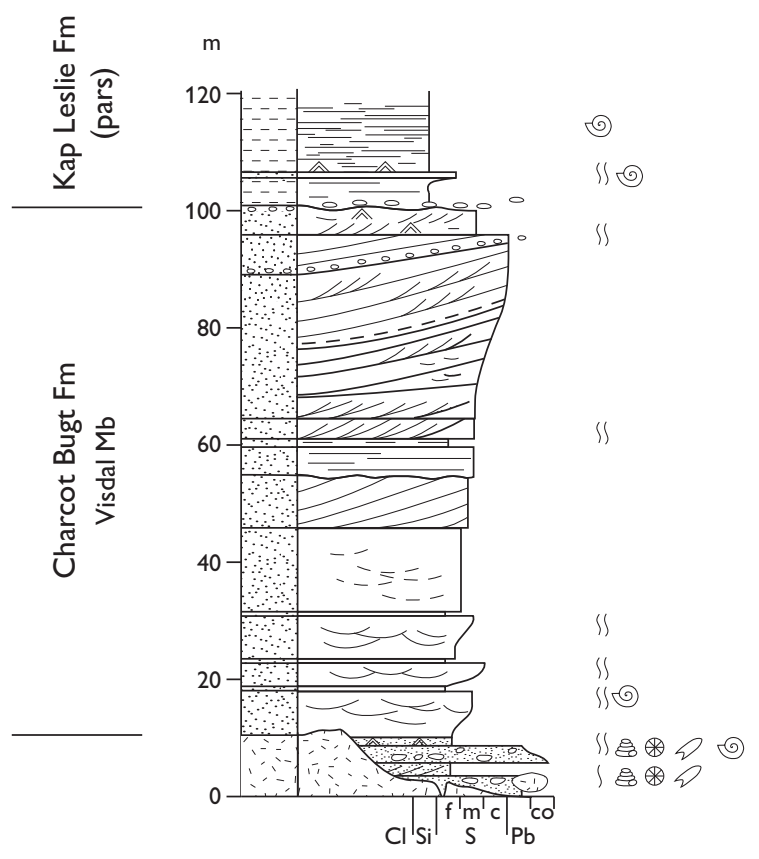

Fig. 75 Composite type section of the Charcot Bugt Formation and the Visdal Member in the Visdal valley, Milne Land (Figs 1, 2b). For legend, see Fig. 7.

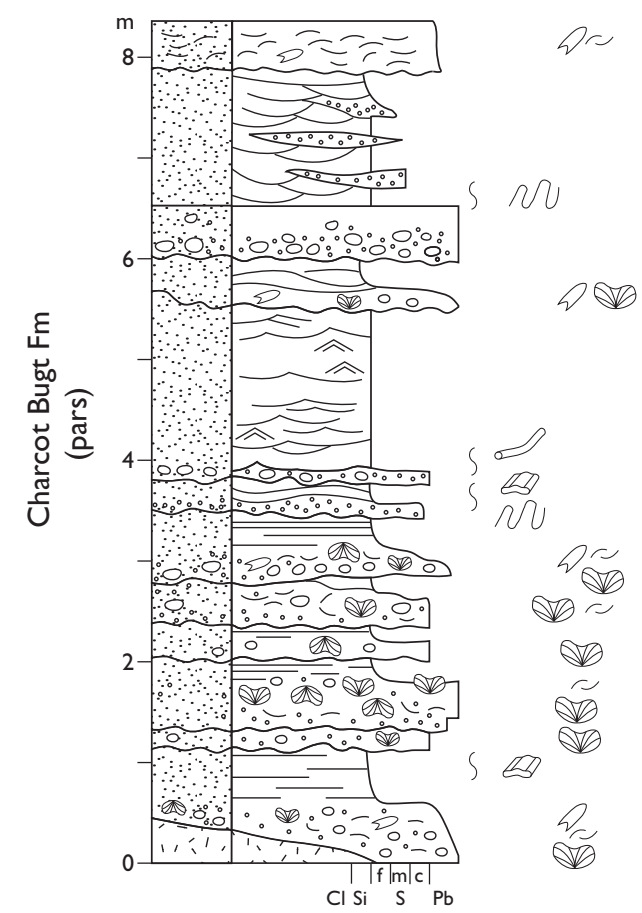

Fig. 76 Detailed log of the basal beds of the Charcot Bugt Formation (and the Visdal Member) forming part of the composite type section of these units in the Visdal valley, Milne Land (Figs 1, 2b). From Larsen et al. (2003, fig. 6). For legend, see Fig. 7. 

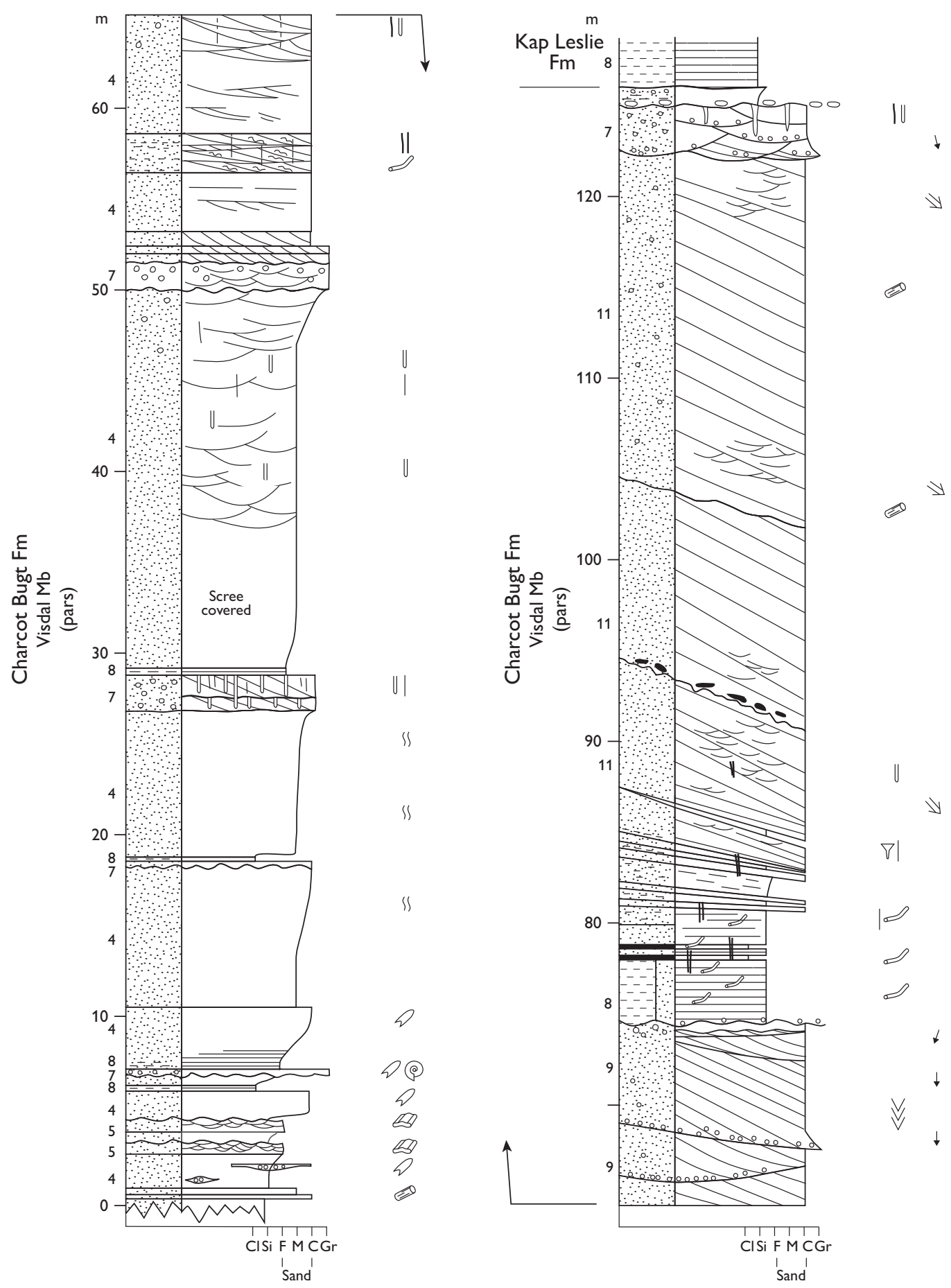

Fig. 77 Section through the upper part of the Visdal Member, Charcot Bugt Formation forming part of the composite type section of these units, corresponding to locality M44 of Birkelund et al. (1984). Visdal, Milne Land (Figs 1, 2b). For legend, see Fig. 7.

Depositional environment. Transgressive shoreface off a rocky coast and prograding shelf-margin wedges.

Boundaries. The lower boundary is a major unconformity and is placed where conglomerates and coarsegrained sandstones onlap an irregular, locally kaolinised inclined surface of crystalline basement rocks (Fig. 76).
The upper boundary is placed at the base of dark grey laminated mudstones of the Kap Leslie Formation, overlying coarse-grained, locally pebbly sandstones; the boundary is a sharp diachronous drowning surface.

Distribution. South-eastern Milne Land and possibly also south-eastern Gåseland (Fig. 1, 2b). 
Chronostratigraphy. Lower Bathonian - middle Oxfordian, the A. arcticus, A. ishmae, A. cranocephaloide and $A$. densiplicatum ammonite zones, faunal horizons M-1 and M-7 of Callomon \& Birkelund (1980) and J-9, J-14 and J-18 of Callomon (1993); dinoflagellate cyst assembages equivalent to the $Q$. mariae and C. cordatum ammonite zones in the upper part (Larsen et al. 2003). Total span is thus the $A$. arcticus to $C$. densiplicatum ammonite zones.

Subdivision. The formation is subdivided (from below) into the Visdal and Mudderbugt Members.

Key references. Aldinger (1935), Håkansson et al. (1971), Beauvais (1977), Callomon \& Birkelund (1980), Larsen (1995), Larsen et al. (2003).

\section{Visdal Member}

History. Erected by Callomon \& Birkelund (1980). Equivalent to the entire Charcot Bugt Formation with the exception of the uppermost $6 \mathrm{~m}$ exposed at southern Visdal, which are referred to the Mudderbugt Member.

Type section. Visdal, south-east Milne Land. Sections M44 $\left(70^{\circ} 39.4^{\prime} \mathrm{N}, 25^{\circ} 46.7^{\prime} \mathrm{W}\right)$ and $\mathrm{M} 49\left(70^{\circ} 41.1^{\prime} \mathrm{N}, 25^{\circ} 49.0^{\prime} \mathrm{W}\right)$ of Birkelund et al. (1984), designated as the combined type section of the Charcot Bugt Formation, are similarly defined as the type section of the Visdal Member (Figs 1, 2b, 75-79).

Reference section. Due to the westward onlap of the formation, the lowest part of the member is probably located to the east in Parat Kløft (Birkelund et al. 1984, section M1) although poorly exposed (Fig. 2b).

Thickness. Up to $200 \mathrm{~m}$.
Lithology. As the formation. Characteristic yellowish white and red weathering colours.

Fossils. As in the formation. A distinctive conglomeratic bed composed of basement clasts, rounded corals, oyster shells and rare ammonites was described from the northern end of Visdal by Callomon \& Birkelund (1980).

\section{Depositional environment. As for the formation.}

Boundaries. The lower boundary is a distinct onlap surface where weathered crystalline basement is overlain by coarse-grained, locally pebbly sandstones and conglomerates of the Visdal Member (Fig. 76). The upper boundary is placed at the base of the coarse- to very coarse-grained pebbly sandstones of the Mudderbugt Member in the southern end of the Visdal valley and elsewhere at the base of dark mudstones of the Kap Leslie Formation. The upper boundary is strongly diachronous, younging to the west. The member interfingers with the Kap Leslie Formation to the east, and in sections of alternating sandstone-mudstone units the boundary is placed at the $50 \%$ cut-off position, above which point mudstones dominate.

\section{Distribution. Same as the formation.}

Chronostratigraphy. Lower Bathonian - middle Oxfordian, $A$. arcticus - $C$. densiplicatum ammonite zones; faunal horizon M-1 of Callomon \& Birkelund (1980) has been identified in the lower part of the member based on ammonites. Dinoflagellate cysts recovered from the uppermost clinoform set in Visdal indicate the middle Oxfordian, corresponding to faunal horizon M-7 of Callomon \& Birkelund (1980).

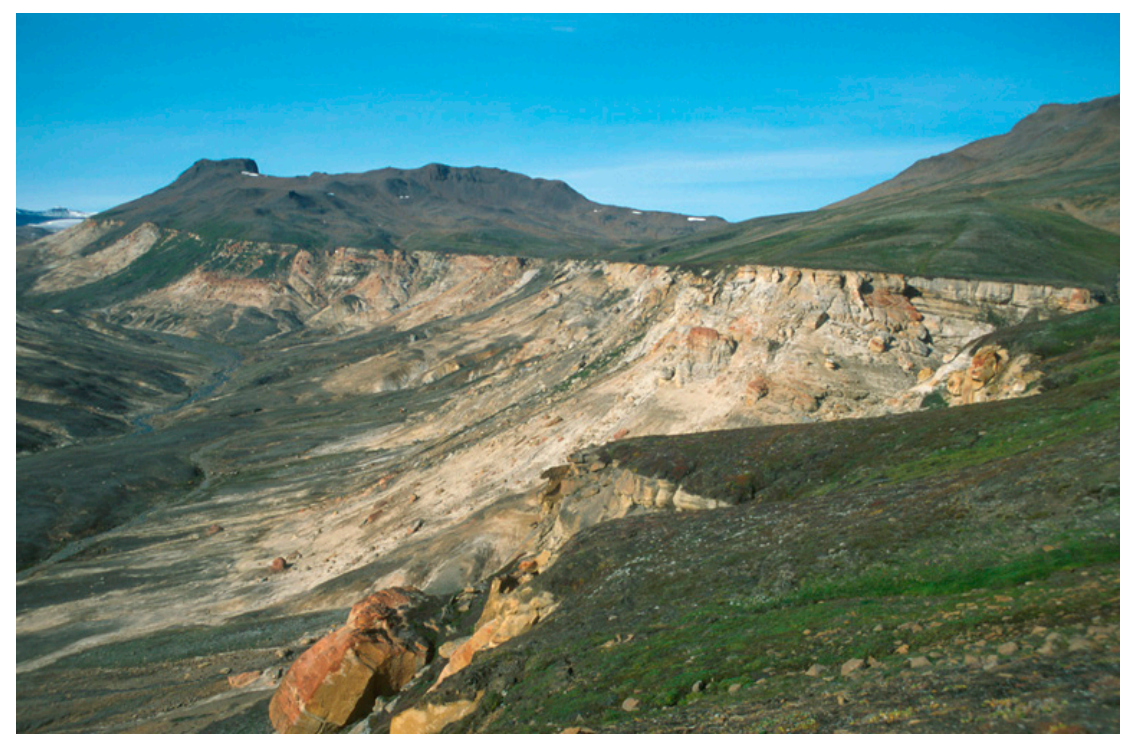

Fig. 78 Sandstones of the Visdal Member, Charcot Bugt Formation, viewed looking north. This section corresponds to locality M44 of Birkelund et al. (1984), forming an important part of the composite type section of the Charcot Bugt Formation and the Visdal Member. Overlain with a sharp boundary by dark mudstones of the Kosmocerasdal Member. Visdal, Milne Land (Figs 1, 2b). 


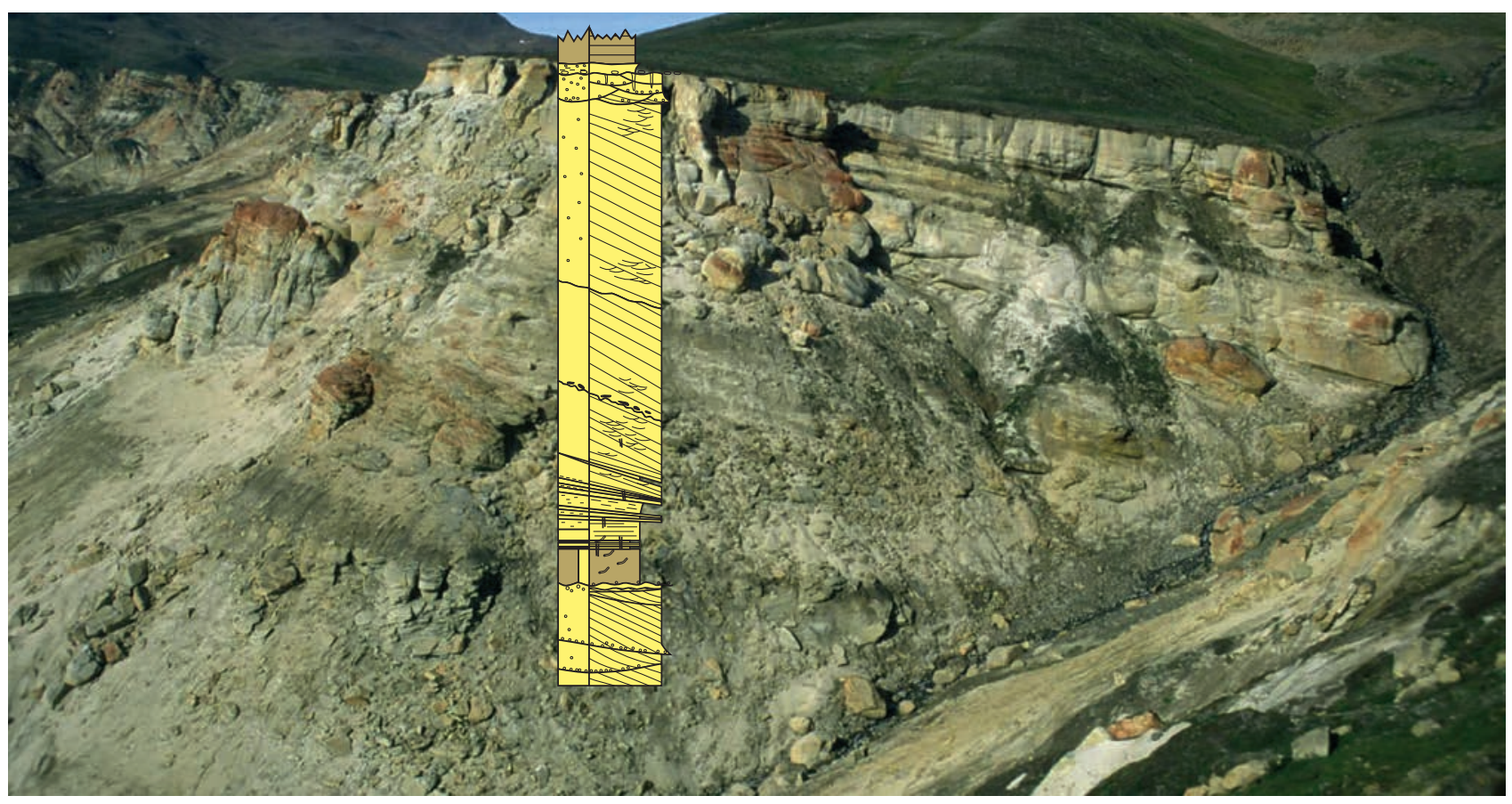

Fig. 79 Upper part of the Visdal Member at the type locality, comprising a $40 \mathrm{~m}$ thick clinoform bed, overlain at a sharp boundary by dark mudstones of the Kosmocerasdal Member (Kap Leslie Formation). Corresponds to locality M44 of Birkelund et al. (1984, see Figs 77, 78). Visdal, Milne Land (Figs 1, 2b).

\section{Mudderbugt Member}

History. Erected by Callomon \& Birkelund (1980).

Type section. Southern Visdal, Milne Land, $70^{\circ} 38.5^{\prime} \mathrm{N}$, $25^{\circ} 48.0^{\prime} W$ (Callomon \& Birkelund 1980, section 40; Figs $1,2 b, 80)$.

Thickness. Up to $6 \mathrm{~m}$.

Lithology. Light grey weathering, very coarse-grained, pebbly trough cross-bedded sandstones, capped by a pebble lag.

Fossils. Bivalves, rare ammonites and trace fossils.

\section{Depositional environment. Shoreface.}

Boundaries. The lower boundary is placed at the base of the lowermost light grey weathering, trough cross-bedded, very coarse-grained and pebbly sandstone, overlying the yellow weathering Visdal Member. The upper boundary is placed at the sharp base of dark mudstones of the Kap Leslie Formation, overlying a pebble lag; this boundary represents a marked flooding surface.

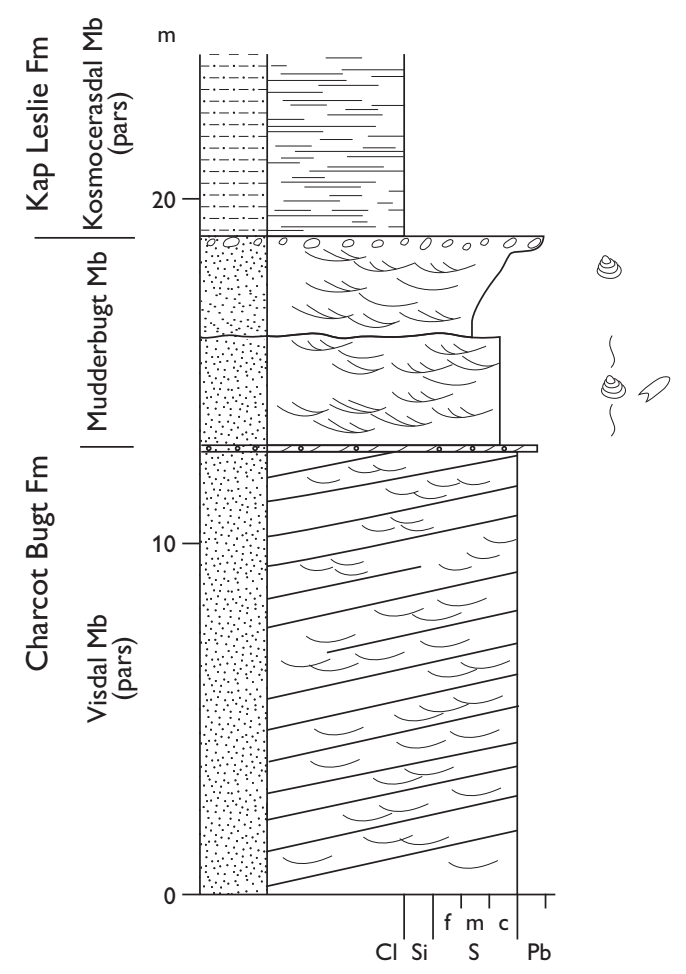

Fig. 80 Type section of the Mudderbugt Member (Charcot Bugt Formation), southern Visdal, Milne Land (Figs 1, 2b). For legend, see Fig. 7. 
Distribution. Southern end of the Visdal valley, Milne Land (Fig. 2b).

Chronostratigraphy. Middle Oxfordian, C. densiplicatum ammonite zone (fauna horizon M-7 of Callomon \& Birkelund 1980), based on ammonites.

\section{Kap Leslie Formation}

History. Erected by Rosenkrantz (1929), revised and described by Callomon \& Birkelund (1980) and Birkelund et al. (1984).

Type area. The eastern slope of Hartz Fjeld is here designated as the type area (see Birkelund et al. 1984, fig. 3; Fig. 2b). For representative sections, see under the individual members. Not all members have measured logs due to the fine-grained nature of the succession, often leading to poor exposure. The formation has a long history of study and the style of the published logs is thus variable.

Thickness. Up to $800 \mathrm{~m}$, thins to $70-80 \mathrm{~m}$ west of Visdal.

Lithology. Dark grey laminated mudstones, grey bioturbated sandy siltstones, subordinate fine- to mediumgrained sandstones, commonly glauconitic. For details, see the component members.

Fossils. Abundant ammonites, belemnites, bivalves, spores, pollen, dinoflagellate cysts and trace fossils; vertebrates, crustaceans, brachiopods, gastropods, serpulids and wood occur locally.

Depositional environment. Lower shoreface - offshore.

Boundaries. The lower boundary is placed at the base of dark grey mudstones, overlying a pebble lag that caps sandstones of the Charcot Bugt Formation, representing a marked drowning surface. The upper boundary is placed at the base of the lowest sandstone bed of the Hartz Fjeld Formation, overlying dark grey mudstones of the Astartedal Member.

Distribution. Eastern Milne Land (Figs 1, 2b).

Chronostratigraphy. Middle Callovian - middle Volgian, S. calloviense - $C$. anguinus ammonite zones, faunal horizon M-35 of Callomon (1993) and faunal horizons M-2 to M-46 of Birkelund et al. (1984), based on ammonites and dinoflagellate cysts.
Subdivision. The formation is subdivided (from below) into the Kosmocerasdal, Aldinger Elv, Bays Elv, Cardioceraskløft, Gråkløft, Krebsedal, Pernaryggen, and Astartedal Members.

Key references. Aldinger (1935), Spath $(1935,1936)$, Callomon \& Birkelund (1980, 1982), Piasecki (1979), Birkelund et al. (1984), Birkelund \& Callomon (1985), Fürsich (1982), Fürsich \& Heinberg (1983), Larsen et al. (2003).

\section{Kosmocerasdal Member \\ History. Erected by Callomon \& Birkelund (1980).}

Type section. Kosmocerasdal $\left(70^{\circ} 44.6^{\prime} \mathrm{N}, 25^{\circ} 29.1\right.$ 'W; Fig. 2b) and the coastal section $1 \mathrm{~km}$ south of Nordøstelv $\left(70^{\circ} 45.3^{\prime} \mathrm{N}, 2^{\circ} 18.3^{\prime} \mathrm{W}\right)$ are here designated a combined type section (Birkelund et al. 1984, sections M2 and M4, respectively; Fig. 81).

Thickness. Up to $170 \mathrm{~m}$ but wedges out westward.

Lithology. Grey bioturbated sandy siltstones, with subordinate thin sandstone beds that increase in abundance in the upper levels of the member.

Fossils. Ammonites, belemnites, bivalves and dinoflagellate cysts.

Depositional environment. Lower shoreface - offshore transition zone.

Boundaries. The lower boundary coincides with the lower boundary of the formation and is placed at the sharp base of dark mudstones overlying sandstones of the Charcot Bugt Formation, at a major flooding surface. The upper levels of the member show a progressive increase in interbedded sandstones, grading into the poorly consolidated sands of the Aldinger Elv Member. The boundary is placed where the proportion of sandstone to siltstone exceeds $50 \%$.

Distribution. Eastern Milne Land, most thickly developed in the Charcot Bugt area (Figs 1, 2b).

Chronostratigraphy. Middle Callovian - upper Oxfordian, S. calloviense - A. glosense ammonite zones, faunal horizon J-35 of Callomon (1993) and faunal horizons M-2 to M-10 of Callomon \& Birkelund (1980) and Birkelund et al. (1984), based on ammonites and indirectly on dinoflagellate cysts. Lower boundary diachronous, younging westwards to the upper Oxfordian. 


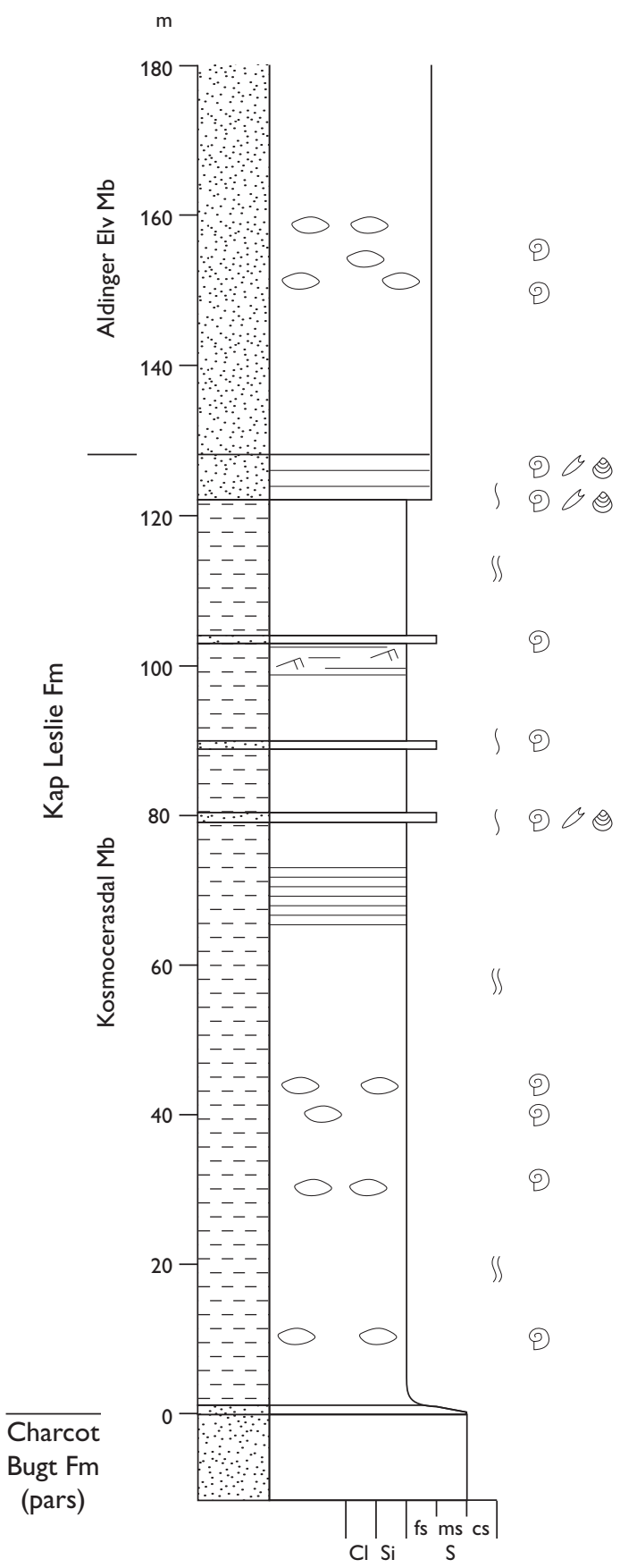

Fig. 81 Type section of the Kosmocerasdal Member (Kap Leslie Formation), Kosmocerasdal, Milne Land (Figs 1, 2b). Modified from Callomon \& Birkelund (1980, fig. 2); re-measured by S. Piasecki. For legend, see Fig. 7.

\section{Aldinger Elv Member}

History. Erected by Callomon \& Birkelund (1980) for the Pecten Sandstone of Aldinger (1935) and described by Fürsich \& Heinberg (1983).

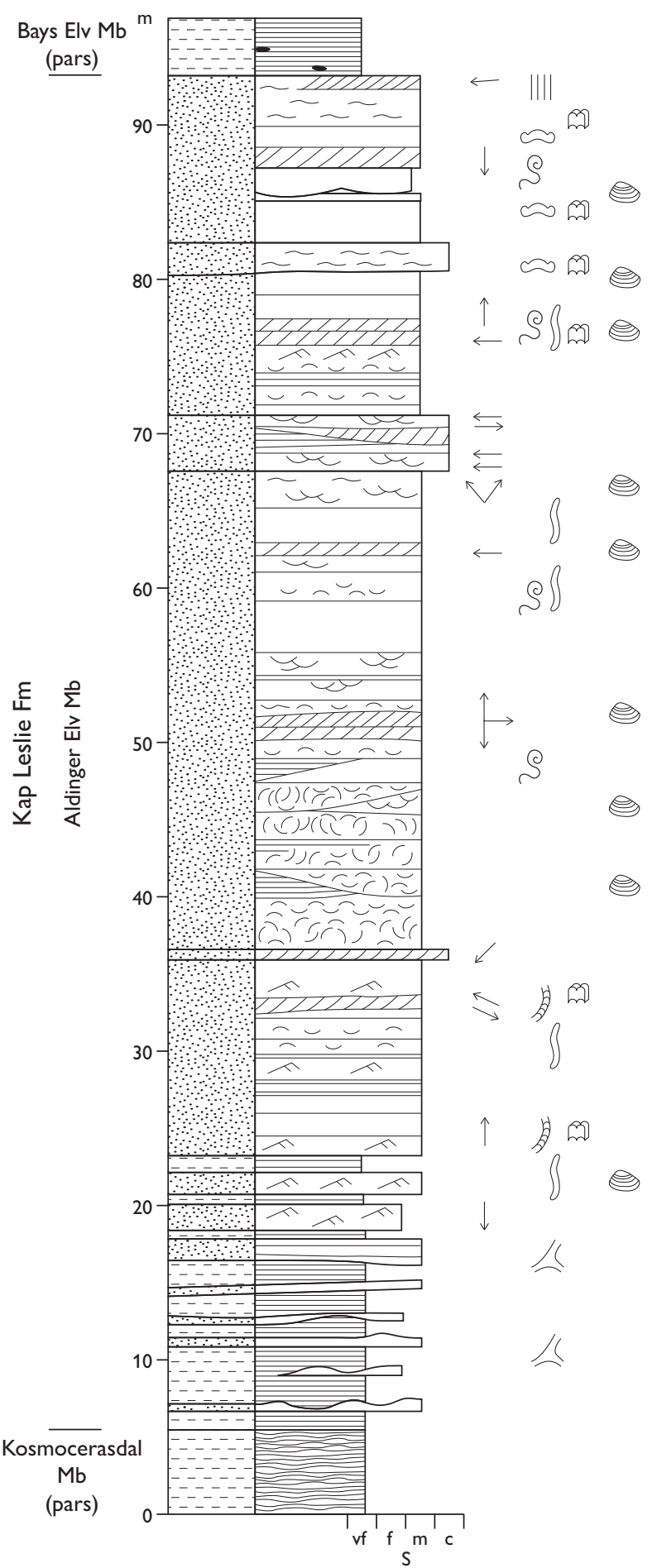

Fig. 82 Type section of the Aldinger Elv Member (Kap Leslie Formation). Milne Land (Figs1, 2b). Schematic composite section. Modified from Fürsich \& Heinberg (1983, Fig. 3). For legend, see Fig. 7.

Type section. A composite type section is designated here (Fig. 82), combining a section in Cardioceraskløft, 7044.8'N, 25¹8.6'W (Fig. 2b; Fürsich \& Heinberg 1983, fig. 1, section 5) and a section between Cardioceraskløft 


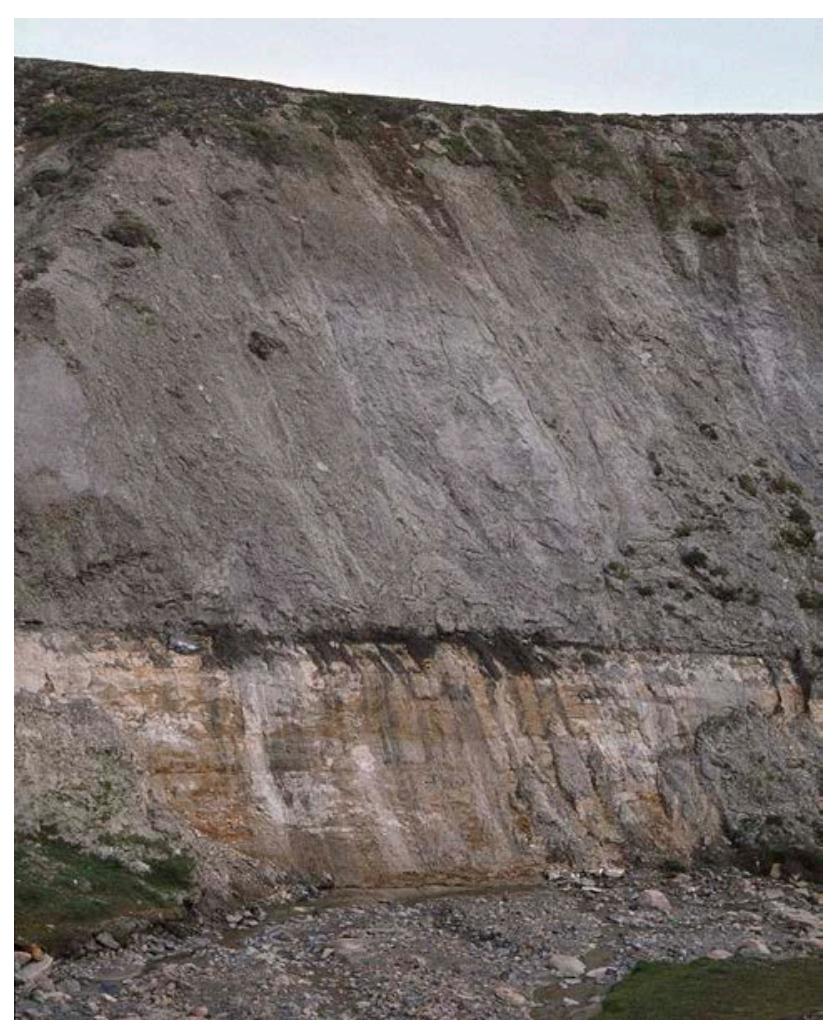

Fig. 83 Yellow sandstones of the uppermost Aldinger Elv Member (c. $6 \mathrm{~m}$ exposed), sharply overlain by black mudstones of the Bays Elv Member (both Kap Leslie Formation). Hartz Fjeld, Milne Land (Figs 1, 2b).

and Aldinger Elv, $70^{\circ} 42.1^{\prime} \mathrm{N}, 2^{\circ} 30.8^{\prime} \mathrm{W}$ (Fig. 2b; Fürsich \& Heinberg 1983, fig. 1, section 25; Birkelund et al. 1984, fig. 2, section M25).

Thickness. Thins from about $70 \mathrm{~m}$ in the east to a few metres in the west.

Lithology. Fine- to medium-grained, poorly cemented cross-bedded sandstones (Fig. 83).

Fossils. Abundant bivalves and serpulids, echinoderms, ammonites, trace fossils and wood fragments.

Depositional environment. Interpreted as an offshore bar by Fürsich \& Heinberg (1983), and as a shelf-margin wedge by Surlyk (2003).

Boundaries. The lower boundary is placed approximately at the $50 \%$ cut-off position between sandy siltstones and well-bedded sandstones of the Kosmocerasdal Member and the loose sandstones of the Aldinger Elv Member. The upper boundary is sharp and placed at the base of alternating sandy siltstones and fine-grained sandstones of the Bays Elv Member (Fig. 83).

Distribution. Eastern Milne Land (Figs 1, 2b).

Chronostratigraphy. Upper Oxfordian, upper A. glosense - A. serratum ammonite zones, faunal horizon M-11 of Callomon \& Birkelund (1980) and Birkelund et al. (1984), based on ammonites and indirectly on dinoflagellate cysts.

\section{Bays Elv Member}

History. Erected by Callomon \& Birkelund (1980).

Type section. Cardioceraskløft, eastern Milne Land, $70^{\circ} 44.2^{\prime} \mathrm{N}, 25^{\circ} 19.6^{\prime} \mathrm{W}$, is here designated the type section (Birkelund et al. 1984, section M6; Figs 1, 2b, 84).

Thickness. Up to $20 \mathrm{~m}$.

Lithology. Alternating sandy siltstones and fine-grained glauconitic sandstones.

Fossils. Few ammonites and bivalves, dinoflagellate cysts.

Depositional environment. Offshore transition zone.

Boundaries. The lower boundary is sharp and placed at the base of sandy siltstones, overlying sandstones of the Aldinger Elv Member. The upper boundary is placed at the top of a widely recognisable green glauconitic sandstone bed, overlain by grey, bioturbated siltstones.

Distribution. Eastern Milne Land (Figs 1, 2b).

Chronostratigraphy. Upper Oxfordian - lowermost Kimmeridgian, A. regulare - $P$. baylei zones, faunal horizons M-12 to M-14 of Callomon \& Birkelund (1980) and Birkelund et al. (1984), based on ammonites and indirectly on dinoflagellate cysts. 


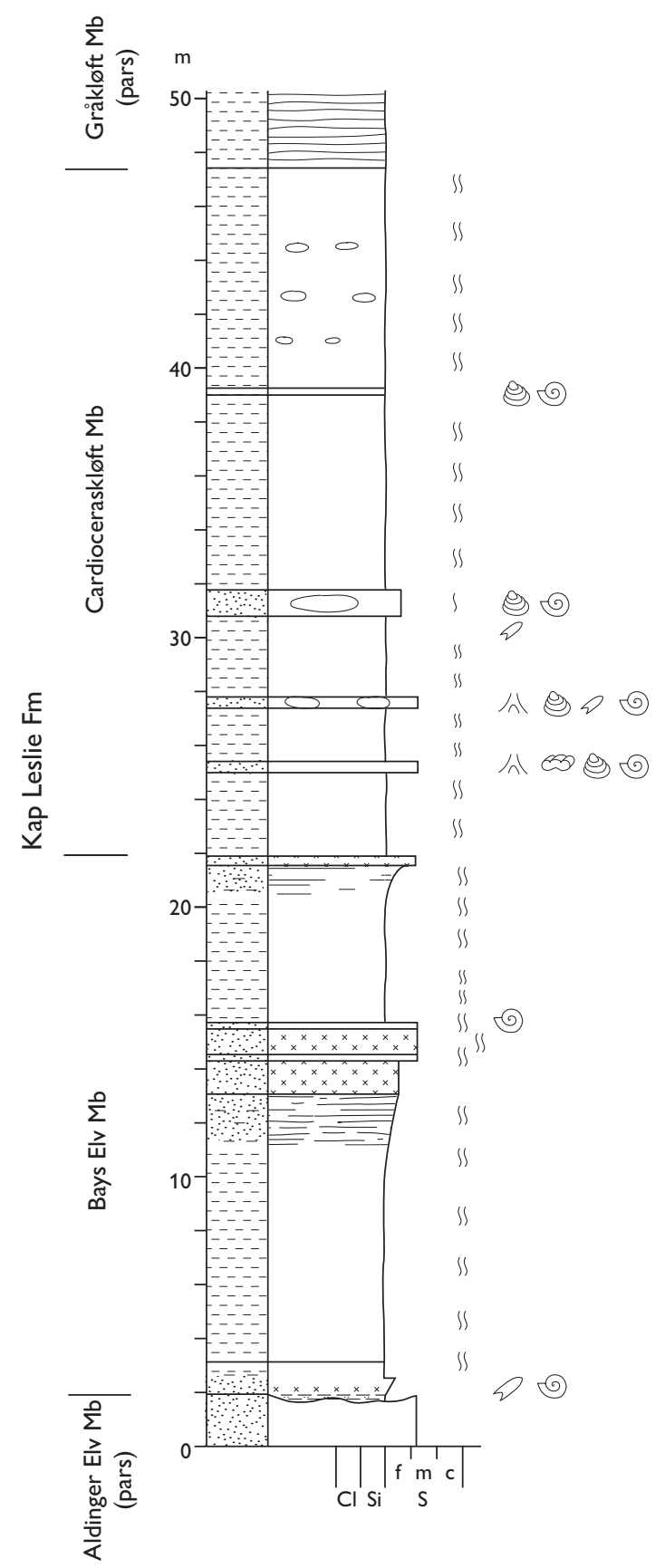

Fig. 84 Type sections of the Bays Elv and Cardioceraskløft Members (both Kap Leslie Formation) at Cardioceraskløft, Milne Land (Figs 1, 2b). For legend, see Fig. 7.

\section{Cardioceraskløft Member \\ History. Erected by Callomon \& Birkelund (1980).}

Type section. Cardioceraskløft, eastern Milne Land, $70^{\circ} 44.2^{\prime} \mathrm{N}, 25^{\circ} 19.6^{\prime} \mathrm{W}$, is here designated the type section (Birkelund et al. 1984, section M6; Figs 1, 2b, 84).

Thickness. $30 \mathrm{~m}$.
Lithology. Grey, highly micaceous, bioturbated siltstones with abundant horizons of calcareous concretions.

Fossils. Ammonites, gastropods and dinoflagellate cysts.

Depositional environment. Offshore marine.

Boundaries. The lower boundary is placed at the base of the lowest grey, bioturbated siltstone, overlying alternating sandy siltstones and fine-grained, glauconitic sandstones of the Bays Elv Member. The upper boundary is placed where black laminated mudstones, referred to the Gråkløft Member, overlie grey bioturbated siltstones of the Cardioceraskløft Member.

Distribution. Eastern Milne Land (Figs 1, 2b).

Chronostratigraphy. Lower Kimmeridgian, R. cymodoce - A. mutabilis ammonite zones, faunal horizons M-15 to M-19 of Birkelund et al. (1984), based on ammonites and indirectly on dinoflagellate cysts.

\section{Gråkløft Member \\ History. Erected by Callomon \& Birkelund (1980).}

Type section. Northern slope of Gråkløft, eastern Milne Land, $70^{\circ} 43.8^{\prime} \mathrm{N}, 2^{\circ} 19.0^{\prime} \mathrm{W}$ (Birkelund et al. 1984, fig. 4, section M8; Figs 1, 2b, 85).

Thickness. $160 \mathrm{~m}$ in the east, wedging out towards the west.

Lithology. Black, laminated, organic-rich mudstone with pyritic beds and concretions.

Fossils. Ammonites, bivalves at a few levels.

Depositional environment. Offshore marine; deposited under dysoxic to anoxic conditions.

Boundaries. The lower boundary is placed at the base of the lowermost laminated black mudstones, overlying grey, bioturbated siltstones. The upper boundary is placed at the base of the lowermost very fine-grained muddy sandstones referred to the Krebsedal Member.

Distribution. Eastern Milne Land (Figs 1, 2b).

Chronostratigraphy. Kimmeridgian - lower Volgian, A. eudoxus - $P$. elegans ammonite zones, faunal horizons M-20 to M-24 of Birkelund et al. (1984), based on ammonites and indirectly on dinoflagellate cysts. 


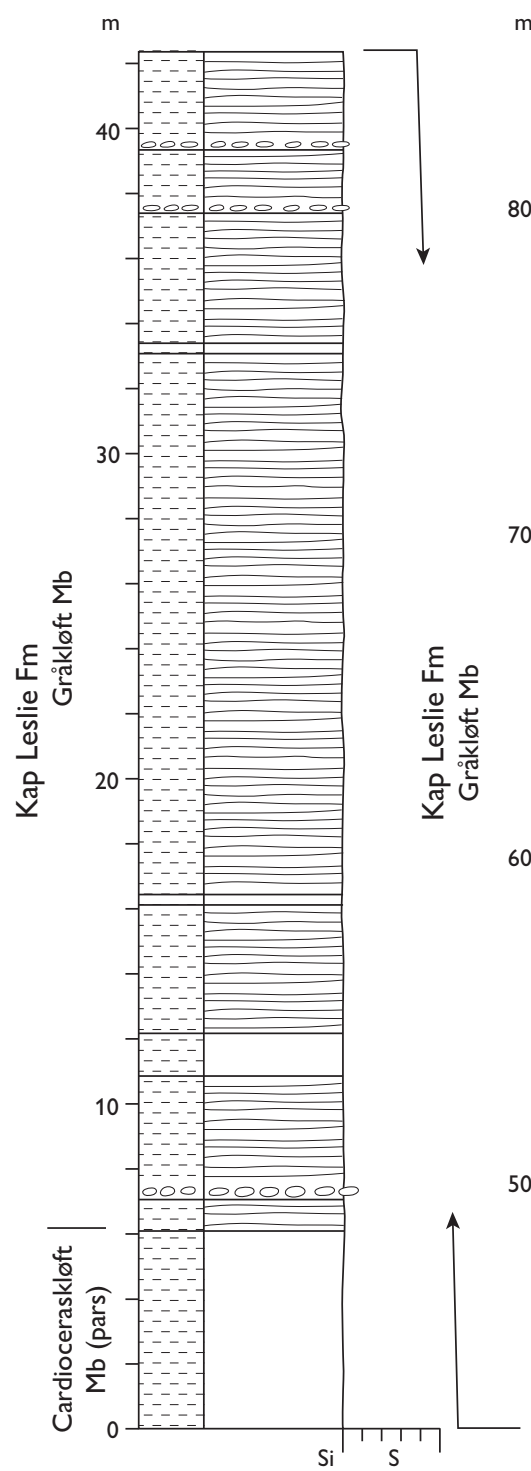

$\mathrm{m}$

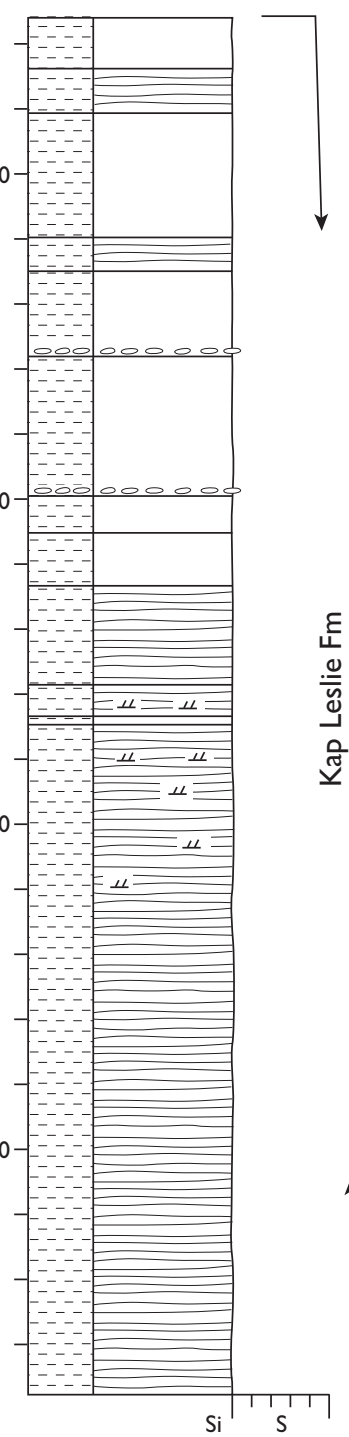

m

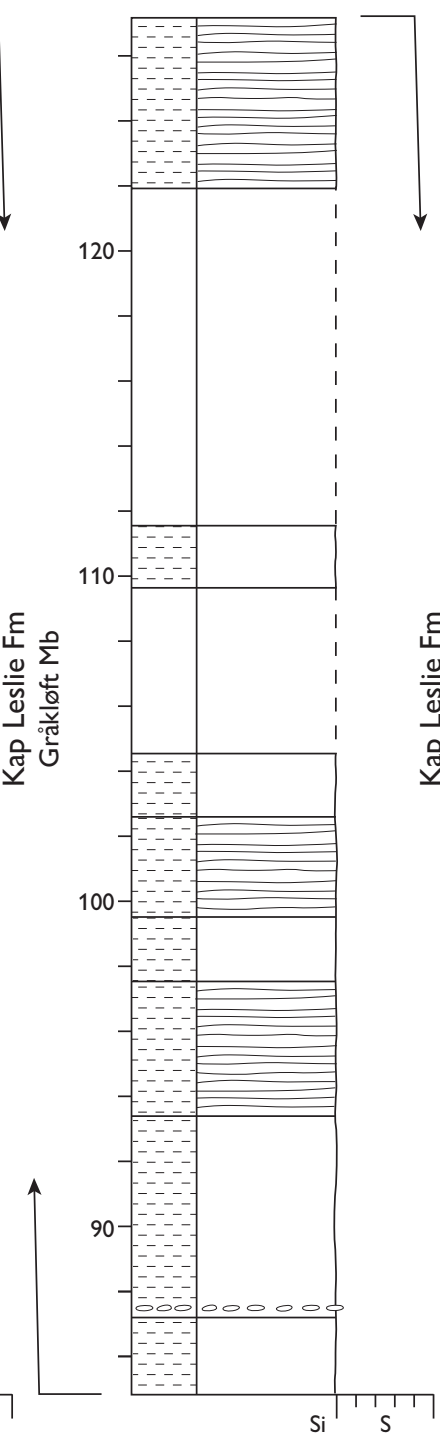

$\mathrm{m}$

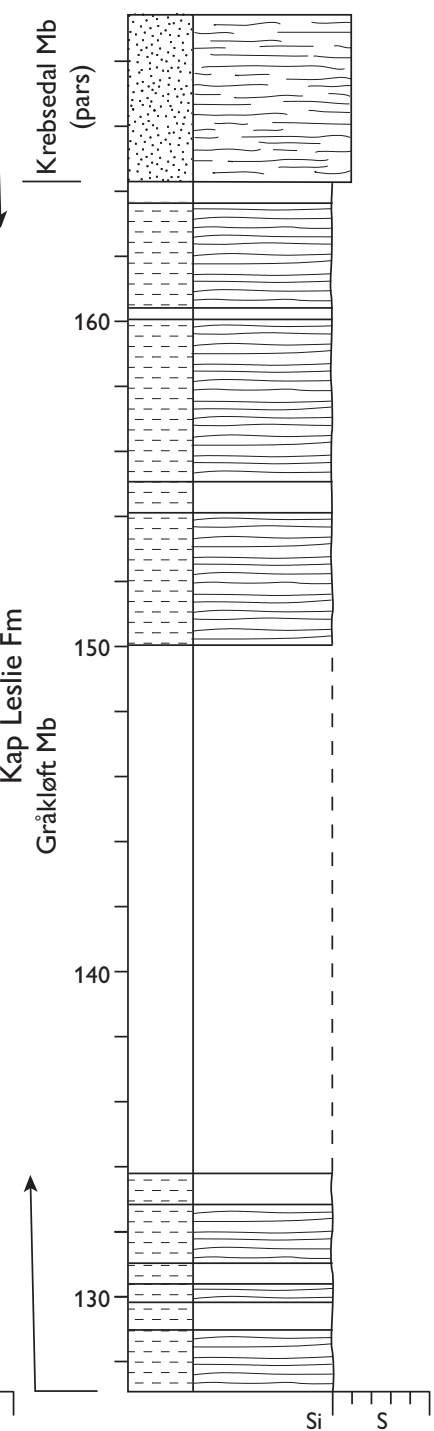

Fig. 85 Type section of the Gråkløft Member (Kap Leslie Formation) at Hartz Fjeld, Milne Land (Figs 1, 2b). Modified from Birkelund et al. (1984, fig. 4). For legend, see Fig. 7.

\section{Krebsedal Member}

History. Erected by Birkelund et al. (1984).

Type section. Ridge south of Krebsedal, eastern Milne Land, $70^{\circ} 41.9^{\prime} \mathrm{N}, 25^{\circ} 18.4^{\prime} \mathrm{W}$ (Birkelund et al. 1984, section M17; Figs 1, 2b, 86).

Thickness. $160 \mathrm{~m}$ at the type section, ranges between 100 and $200 \mathrm{~m}$.

Lithology. Grey, very fine- to fine-grained muddy sandstone. Quartz pebbles and glaucony grains recorded locally in the basal levels. The upper part of the member at the Kronen mountain consists of large-scale cross-bedded sandstone (Birkelund et al. 1984).
Fossils. Ammonites, belemnites, bivalves, crustaceans, ichthyosaurs, plesiosaurs, dinoflagellate cysts and trace fossils.

Depositional environment. Marine, offshore transition zone to lower shoreface.

Boundaries. The lower boundary is placed where finegrained muddy sandstones overlie black laminated mudstones of the Gråkløft Member. The upper boundary is placed at the base of the lowermost glauconitic sandstone of the Pernaryggen Member; this boundary is diachronous.

Distribution. Eastern Milne Land (Figs 1, 2b). 


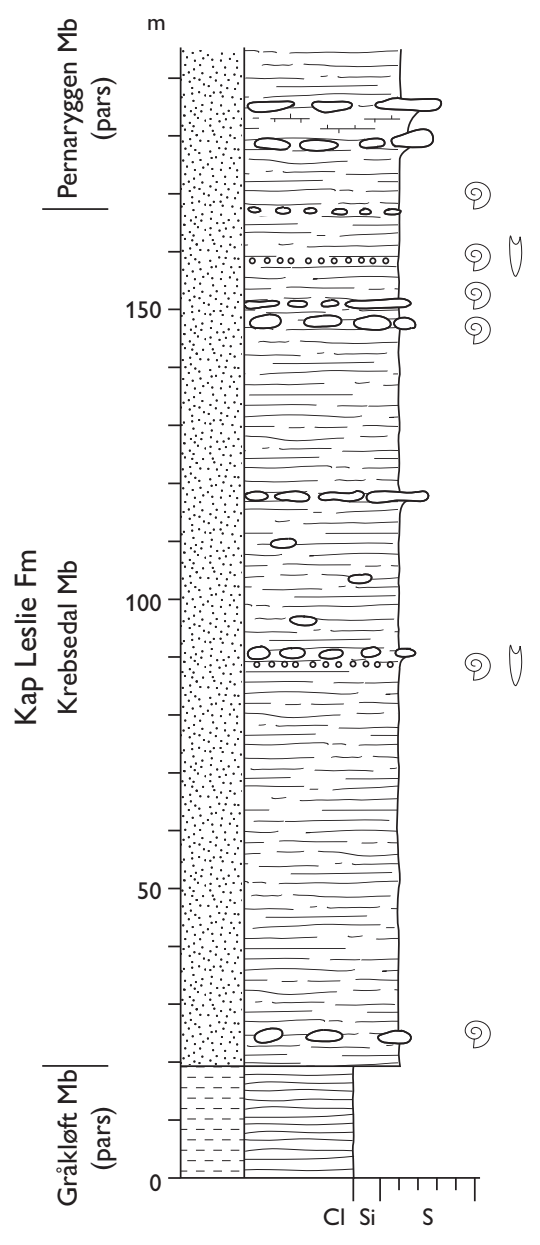

Fig. 86 Type section of the Krebsedal Member (Kap Leslie Formation) in the Krebsedal valley, Milne Land (Figs 1, 2b). Modified from Birkelund et al. (1984, fig. 7). For legend, see Fig. 7.

Chronostratigraphy. Lower-middle Volgian, P. wheatleyensis - D. liostracus ammonite zones, faunal horizons M-25 to M-37 of Birkelund et al. (1984).

\section{Pernaryggen Member}

History. Erected by Birkelund et al. (1984).

Type section. Pernaryggen, eastern Milne Land, $70^{\circ} 43.0^{\prime} \mathrm{N}$, 2526.6'W (Birkelund et al. 1984, section M23; Figs 1, 2b, 87).

Thickness. $53 \mathrm{~m}$ at the type section, thins westward to $15 \mathrm{~m}$ at Bay Fjelde.

Lithology. Bioturbated, micaceous and glauconitic sandstone dominate the member (Fig. 88). Large-scale cross-bedded sandstones are prominent at the base of the type section.

Fossils. Ammonites, belemnites, bivalves, brachiopods, serpulids, gastropods, crustaceans and trace fossils.

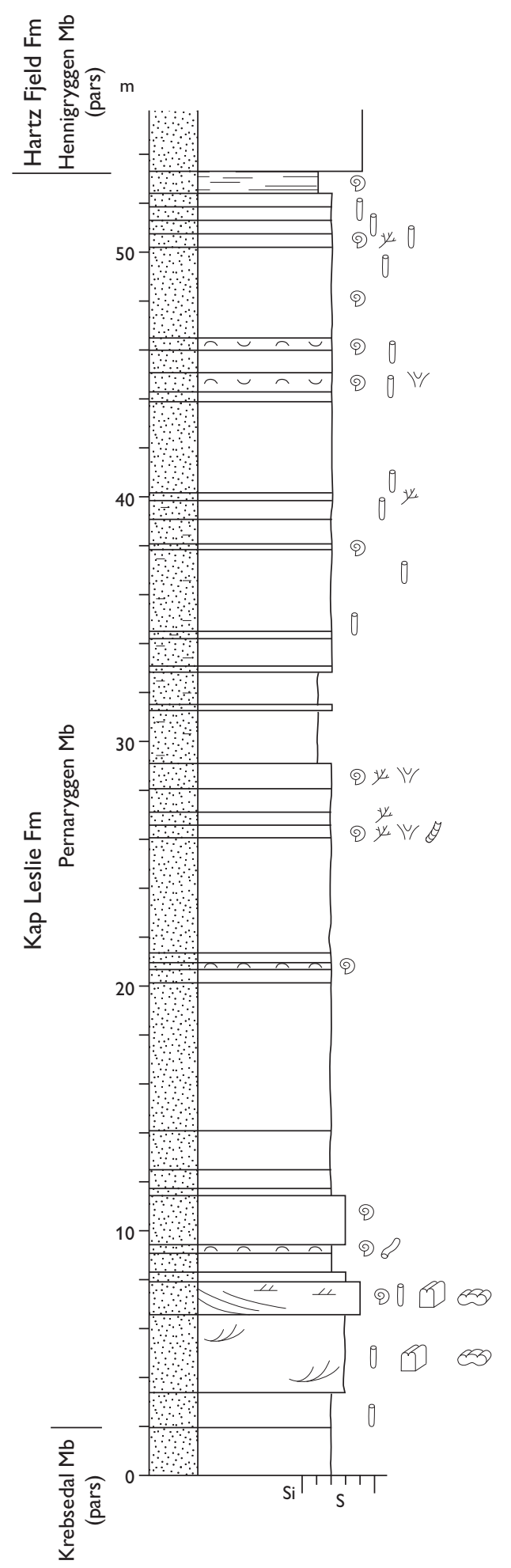

Fig. 87 Type section of the Pernaryggen Member (Kap Leslie Formation) at Pernaryggen, Milne Land (Figs 1, 2b). Modified from Birkelund et al. (1984, fig. 8). For legend, see Fig. 7.

Depositional environment. Lower and upper shoreface.

Boundaries. The lower boundary is placed at the lowest glauconitic sandstone, overlying finer-grained nonglauconitic sandstones of the Krebsedal Member. The 


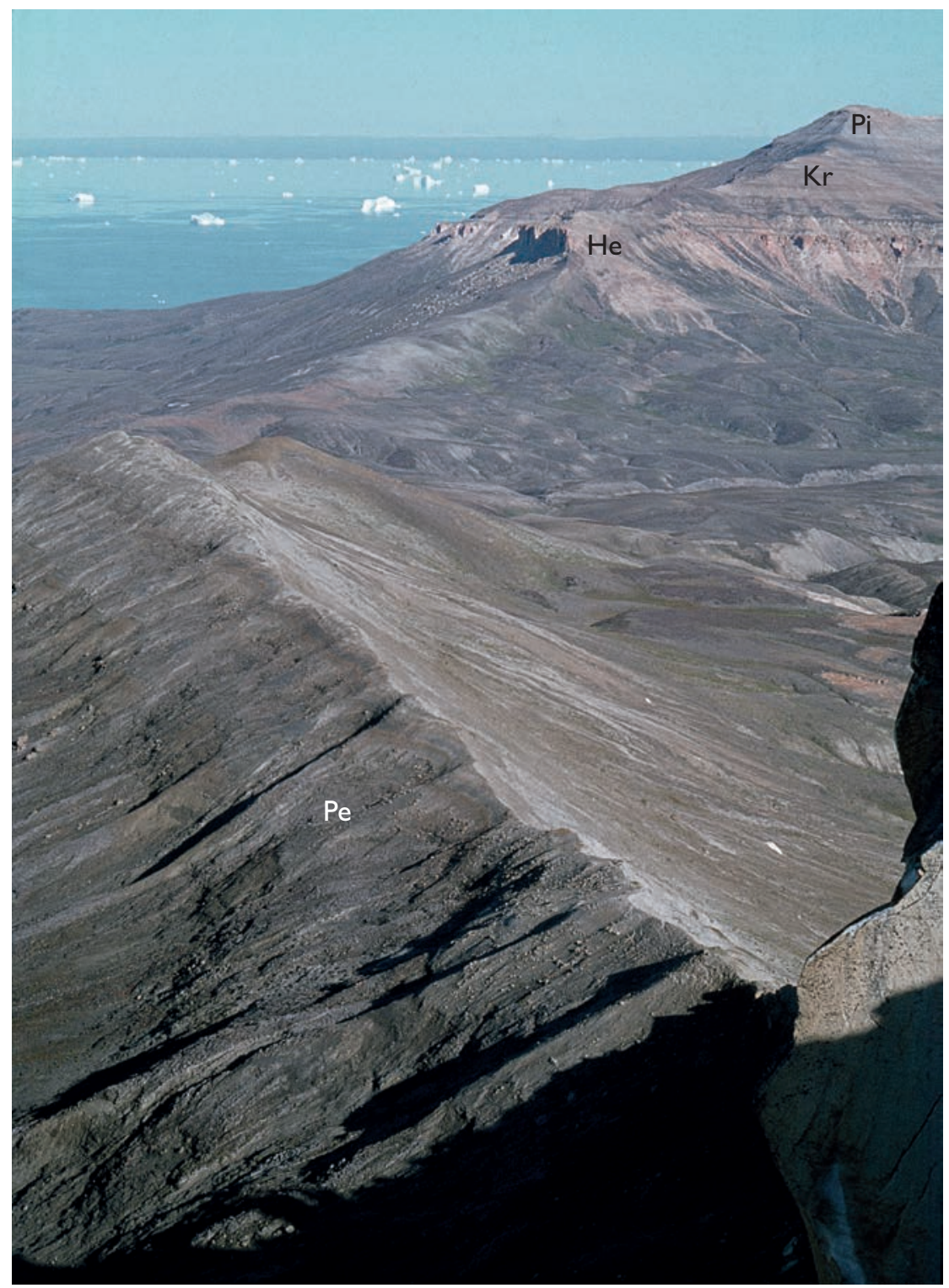

Fig. 88 Ridge exposing micaceous and glauconitic sandstones of the Pernaryggen Member (Pe) of the Kap Leslie Formation. Photograph taken from the mountain of Kronen towards Hartz Fjeld, where the Hennigryggen $(\mathbf{H e})$ and Kronen (Kr) Members of the Hartz Fjeld Formation are exposed, capped by the Pinnadal Formation (Pi). Milne Land (Figs $1,2 b)$.

upper boundary is placed at the base of the lowest silty micaceous mudstone of the Astartedal Member, if present, or at the erosional unconformity beneath the yellow sandstones of the Hartz Fjeld Formation.

Distribution. Milne Land (Figs 1, 2b).

Chronostratigraphy. Middle Volgian, P. rugosa - C. anguinus ammonite zones, faunal horizons M-33 to M-45 of Birkelund et al. (1984).

\section{Astartedal Member}

History. Erected by Birkelund et al. (1984).

Type section. Ridge south of Krebsedal, eastern Milne Land, $70^{\circ} 41.9^{\prime} \mathrm{N}, 25^{\circ} 18.4^{\prime} \mathrm{W}$ (Birkelund et al. 1984, section M17; Figs 1, 2b, 89).
Thickness. 20-26 m in the type area, wedges out towards the north.

Lithology. Light grey, micaceous, silty very fine-grained bioturbated loose sands. Large-scale cross-bedding is locally recognisable.

Fossils. Ammonites, belemnites, bivalves, trace fossils, plant debris and wood fragments.

Depositional environment. Shoreface and offshore transition zone.

Boundaries. The lower boundary is placed at the base of the lowest light grey, bioturbated, very fine-grained sandstones, overlying glauconitic sandstones of the Pernaryggen Member; at most localities, this is a sharp boundary. The upper boundary is an erosional 


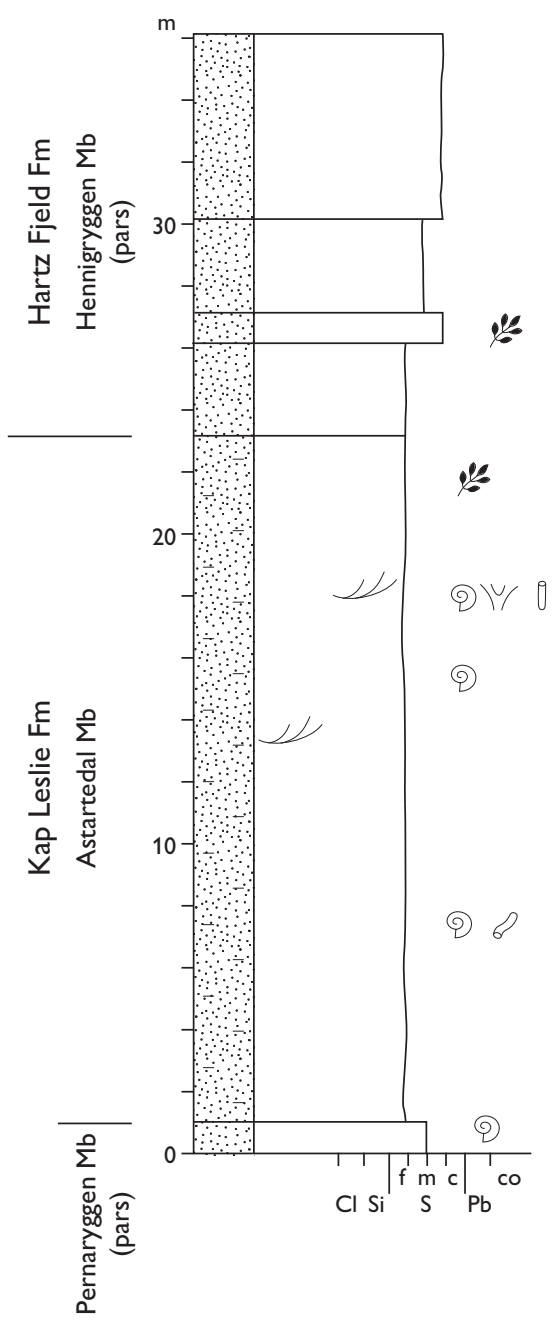

Fig. 89 Type section of the Astartedal Member (Kap Leslie Formation) in the Krebsedal valley, Milne Land (Figs 1, 2b). Modified from Birkelund et al. (1984, fig. 10). For legend, see Fig. 7.

unconformity at the base of yellow non-micaceous quartz sandstones of the Hartz Fjeld Formation.

Distribution. Very restricted extent in the Hartz Fjeld area, eastern Milne Land (Figs 1, 2b).

Chronostratigraphy. Middle Volgian. L. groenlandicus ammonite zone, faunal horizon M-46 of Birkelund et al. (1984).

\section{Hartz Fjeld Formation}

History. Erected by Rosenkrantz (1929), described by Sykes \& Brand (1976), and subdivided by Birkelund et al. (1984) into the Hennigryggen and Pinnadal Members. The Hennigryggen Member of Birkelund et al. (1984) is redefined herein, and the Pinnedal Member is elevated to formation status.
Type section. The type section is defined by its constituent members.

Thickness. About 300 m.

Lithology. Fine- to coarse-grained sandstone showing cross-bedding and high-angle clinoform bedding.

Fossils. Bivalves, rare ammonites, brachiopods, plant fragments and trace fossils.

Depositional environment. Shoreface, shelf-margin wedge.

Boundaries. The lower boundary is placed at the base of cross-bedded or clinoform-bedded sandstones, unconformably overlying micaceous, silty mudstones or loose sands of the Kap Leslie Formation. The formation forms the uppermost stratal units on the Kronen and Bay Fjelde mountains. It is succeeded by the Pinnadal Formation on the mountain of Hartz Fjeld where the boundary is placed at the base of a prominent dark grey silty mudstone unit, overlying pebbly sandstones or a marked pebble lag.

Distribution. Milne Land (Figs 1, 2b).

Chronostratigraphy. Middle Volgian - Valanginian, based on ammonites and dinoflagellates.

Subdivision. The formation is subdivided into the Hennigryggen Member and the overlying new Kronen Member. An important upper Volgian - Ryazanian hiatus separates the lower and the upper parts of the Hennigryggen Member as originally defined by Birkelund et al. (1984). The Hennigryggen Member is here redefined to only include the lower part, whereas the upper part is referred to the new Kronen member. The Hennigryggen Member is thus of Middle Volgian age, whereas the Kronen Member is of Valanginian age. The Pinnadal Member of Birkelund et al. (1984) is herein excluded from the Hartz Fjeld Formation and is elevated to the rank of formation.

Key references. Sykes \& Brand (1976), Piasecki (1979), Birkelund et al. (1984), Surlyk \& Noe-Nygaard (1995), Surlyk (2003).

\section{Hennigryggen Member \\ revised member}

History. Erected by Birkelund et al. (1984). The Hennigryggen Member as defined by Birkelund et al. (1984) conceals a major hiatus, corresponding to an important 


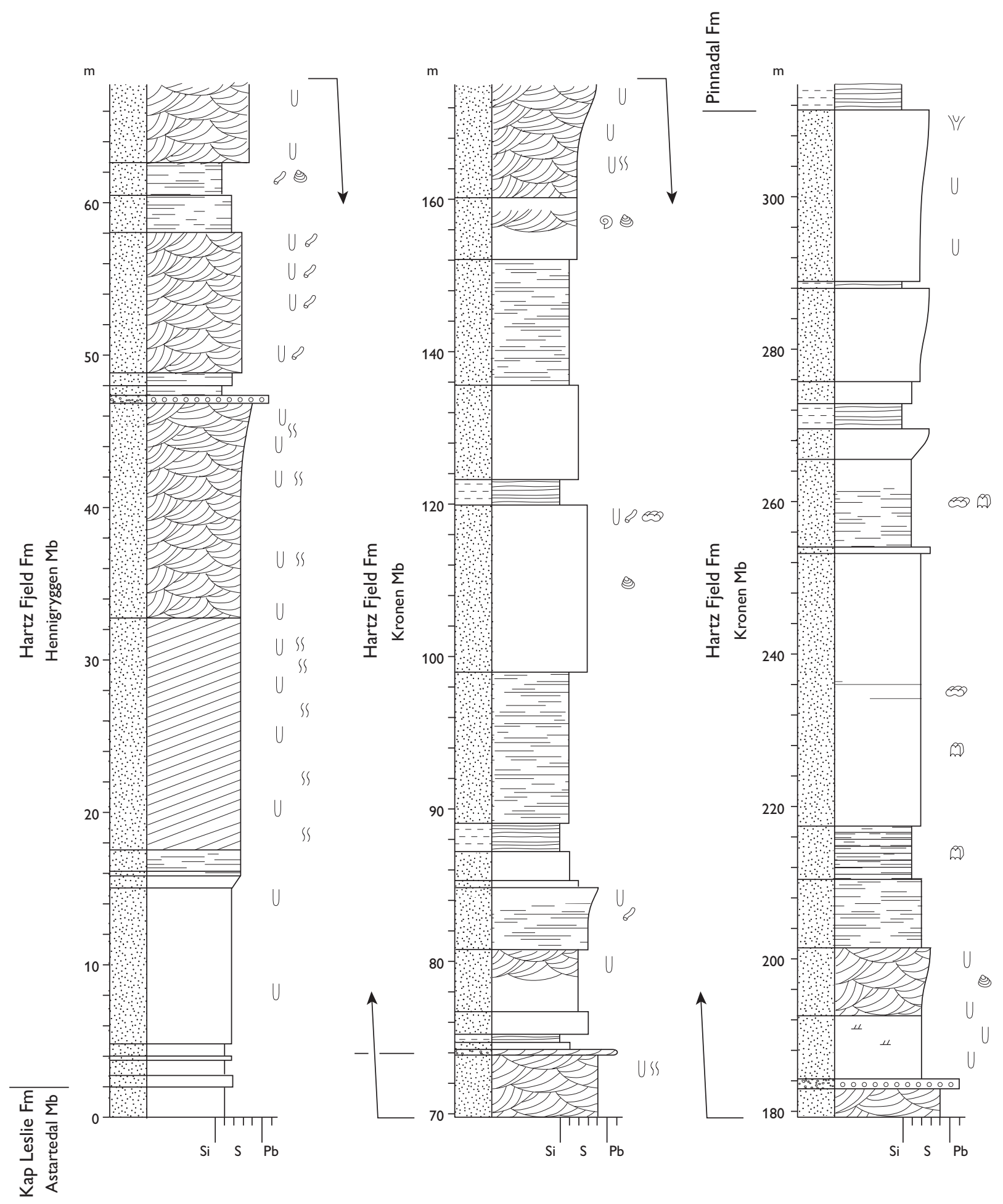

Fig. 90 Type sections of the Hennigryggen and Kronen Members, both Hartz Fjeld Formation. Hartz Fjeld, Milne Land (Figs 1, 2b). Modified from Birkelund et al. (1984, fig. 11). For legend, see Fig. 7.

unconformity covering all of the upper Volgian - Ryazanian (Birkelund et al. 1984). The member is thus redefined here, being restricted to only include the lower part, below the unconformity.
Type section. North-east corner of the mountain of Hartz Fjeld, eastern Milne Land, $70^{\circ} 43.2^{\prime} \mathrm{N}, 2^{\circ} 20.4^{\prime} \mathrm{W}$ (Birkelund et al. 1984, section M9, equivalent to the 'upper section' of Sykes \& Brand 1976; Figs 1, 2b, 90). 


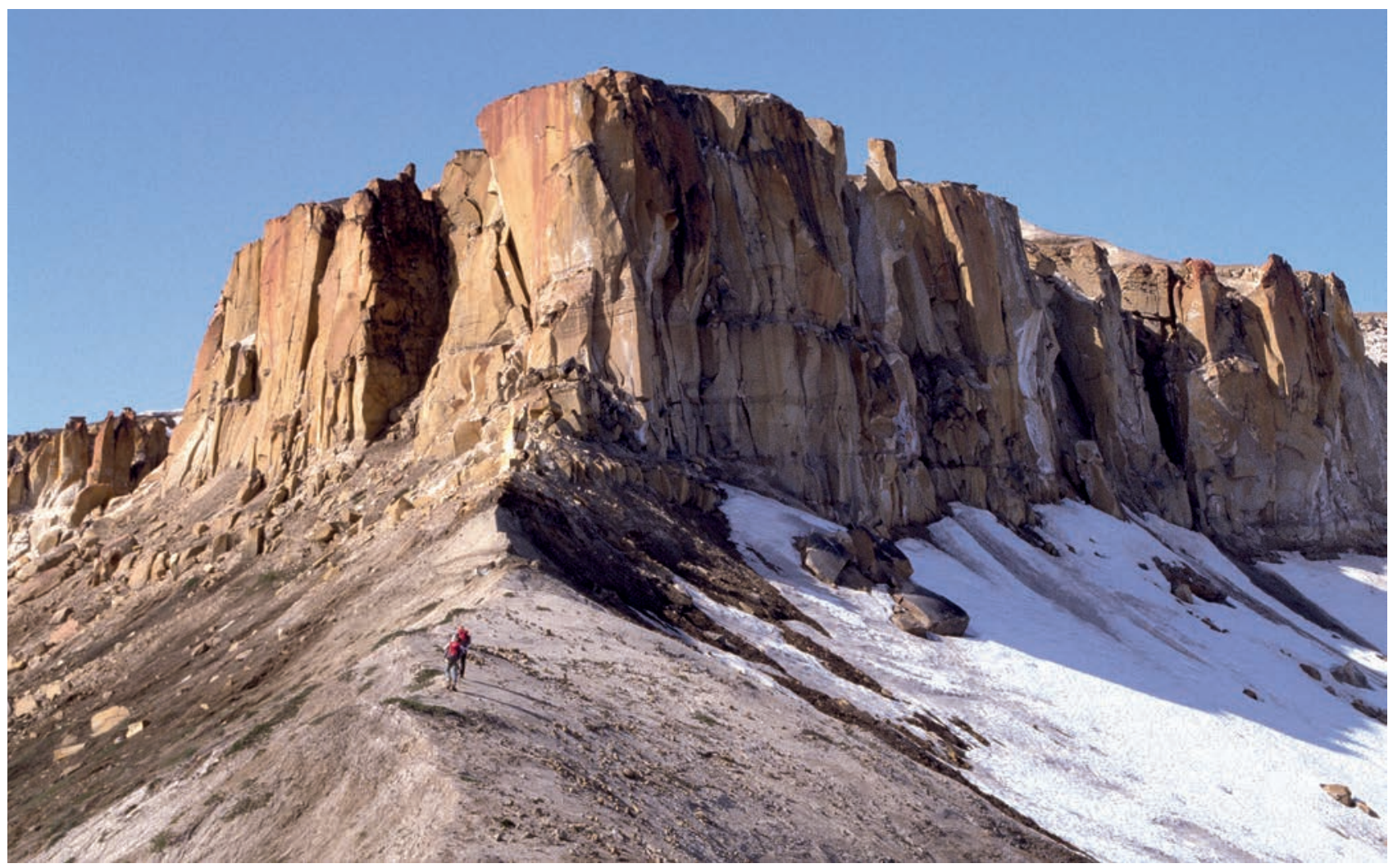

Fig. 91 Light grey, silty, very fine-grained sands of the Pernaryggen Member (Kap Leslie Formation, persons for scale standing on this member) overlain by yellow sandstones of the Hennigryggen Member, Hartz Fjeld Formation. The mountain of Kronen (west of Hartz Fjeld), Milne Land, looking towards the west (Figs 1, 2b).

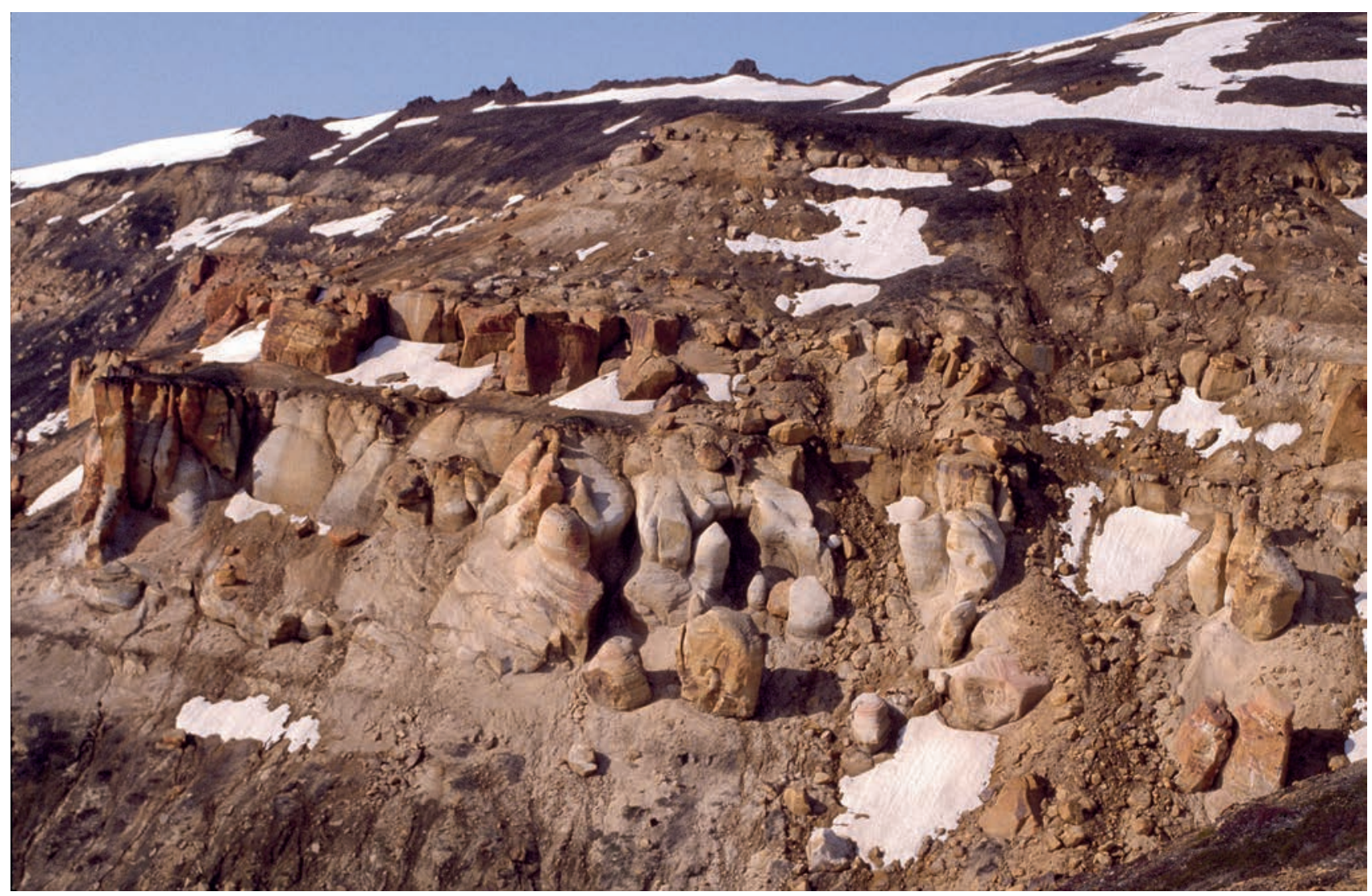

Fig. 92 Photograph of the thick-bedded Hennigryggen Member. The sandstone-dominated succession (up to the dark ledges) corresponds to the lowest c. $70 \mathrm{~m}$ of the succession shown in Fig. 90. Western side of the Hartz Fjeld mountain, Milne Land (Figs 1, 2b). 
Thickness. About 200 m.

Lithology. Stacked coarsening-upward, cross-bedded and high-angle clinoform-bedded, commonly glauconitic sandstones (Figs 91, 92).

Fossils. Bivalves, rare ammonites, brachiopods, plant fragments, and trace fossils.

Depositional environment. Marine shoreface and shelfmargin wedge.

Boundaries. The lower boundary coincides with that of the formation. The upper boundary is placed at the base of cross-bedded sandstones of the new Kronen Member at an unconformity that represents a major hiatus.

Distribution. The member is known from the mountains of Hartz Fjeld, Kronen and Bay Fjelde in Milne Land (Figs $1,2 b)$.

Chronostratigraphy. Middle Volgian, L. groenlandicus ammonite zone, faunal horizon M-47 of Birkelund et al. (1984).

\section{Kronen Member}

new member

History. This new member formed the upper part of the Hennigryggen Member of previous usage (Birkelund et al. 1984). A major hiatus corresponding to all of the upper Volgian and the Ryazanian occurs in the middle of the member as originally defined, and the Hennigryggen Member is revised here to only include the part below the unconformity. The upper part is here defined as the new Kronen Member.

Type section. Same locality as for the Hennigryggen Member. North-east corner of the mountain of Hartz Fjeld, eastern Milne Land, $70^{\circ} 43.2^{\prime} \mathrm{N}, 2^{\circ} 20.4^{\prime} \mathrm{W}$ (Birkelund et al. 1984, section M9, equivalent to the 'upper section' of Sykes \& Brand 1976; Figs 1, 2b, 90).

Reference section. The mountain of Kronen, west of Hartz Fjeld, $70^{\circ} 42.9^{\prime} \mathrm{N}, 25^{\circ} 27.6^{\prime} \mathrm{W}$ (Birkelund et al. 1984, section M23; Figs 1, 2b).

Thickness. About $130 \mathrm{~m}$ based on our interpretation of data in Birkelund et al. (1984).

Lithology. Stacked coarsening-upward sandstone-dominated units showing trough and low-angle cross-bedding and thick clinoform beds; some coarsening-upward units have a basal siltstone interval. In many cases, these units are capped by a ferruginous crust that may be associated with pebble beds; the trace fossil Tisoa habichi extends down from the top of many such units. Carbonaceous matter occurs scattered. Post-depositional decalcification has resulted in the loss of shelly fossils and the obliteration of sedimentary structures in many beds.

Fossils. Ammonites, trace fossils including Tisoa habichi, Planolites, Curvolithus and Gyrochorte, casts of wood logs.

Depositional environment. Progradational marine shorefaces and shelf-margin wedges.

Boundaries. The lower boundary is placed at the top of a marked pebble lag that caps the upper coarsening-upwards sandstone unit of the redefined Hennigryggen Member; this lag is overlain by cross-bedded sandstones referred to the Kronen Member. The upper boundary is placed where coarsening-upwards sandstones are succeeded by alternating silty mudstones and coarse-grained sheet sandstones of the lower Pinnadal Formation.

Distribution: The Hartz Fjeld and Kronen mountains, Milne Land (Figs 1, 2b).

Chronostratigraphy. Lowermost Valanginian Tollia klimovskiensis ammonite zone has been identified (faunal horizon M-48 of Callomon \& Birkelund 1982). The top of the redefined Hennigryggen Member contains middle Volgian ammonites, whereas the basal beds of the new Kronen Member contain early Valanginian or possibly late Ryazanian ammonites. The hiatus between the two members thus comprises all of the upper Volgian Substage and all or most of the Ryazanian Stage. An important hiatus may also be present between the Kronen Member and the overlying Pinnadal Formation, as much of the Valanginian is apparently absent. Biostratigraphical data from the Pinnadal Formation are, however, very sparse.

\section{Pinnadal Formation revised unit}

History. Erected as a member by Birkelund et al. (1984). Elevated herein to the rank of formation.

Type locality. Pinnadal, north-east corner of Hartz Fjeld, $70^{\circ} 43.1^{\prime} \mathrm{N} 25^{\circ} 20.4^{\prime} \mathrm{W}$ (Sykes \& Brand 1976, fig. 1; Figs 1, 2b). The locality is poorly known; representative detailed 

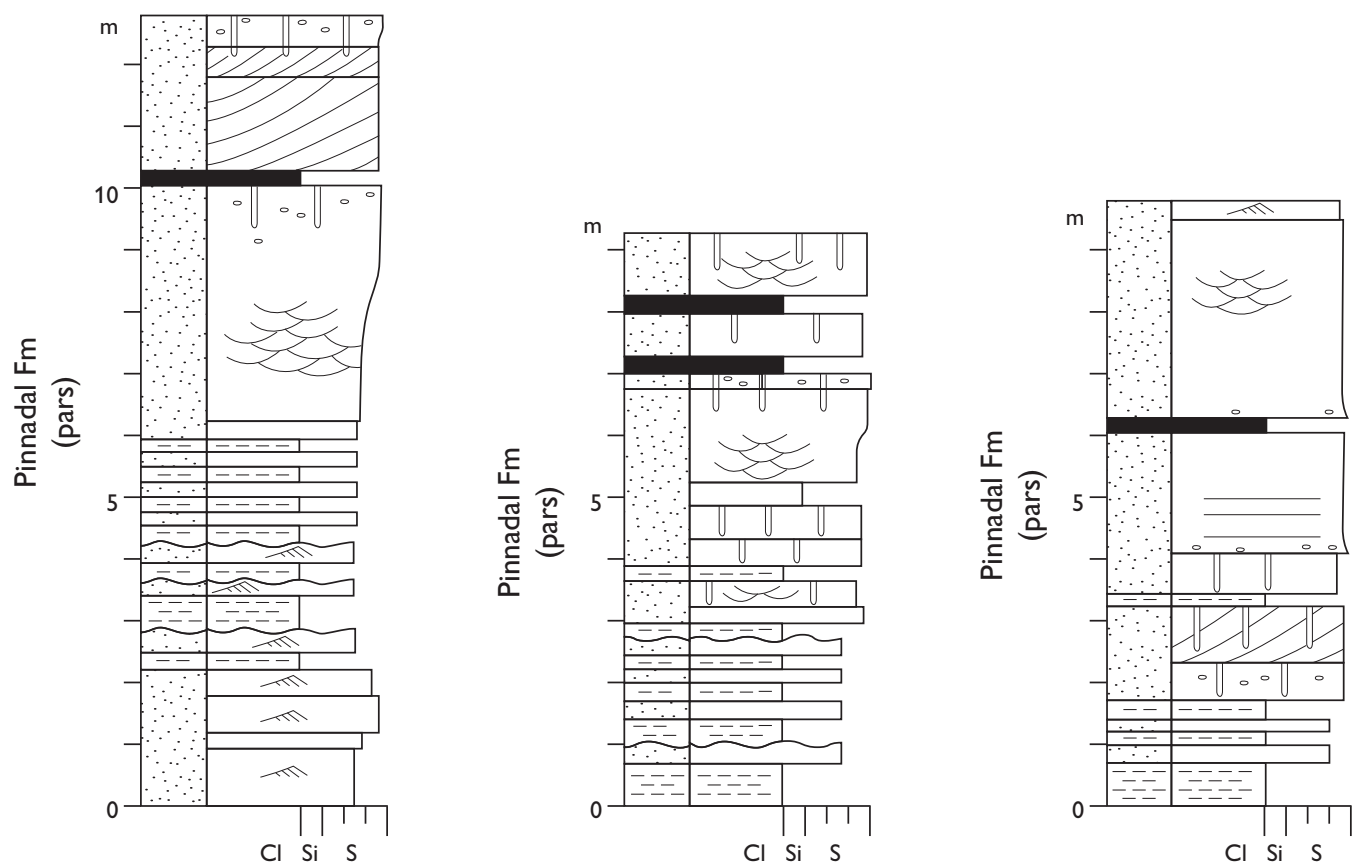

Fig. 93 Representative sections from the type locality of the Pinnadal Formation (Hartz Fjeld Formation) in the Pinnadal valley, Milne Land (Figs 1, 2b). Modified from Sykes \& Brand (1976, fig. 6). For legend, see Fig. 7.

sections modified from Sykes \& Brand (1976, fig. 6) are shown in Fig. 93.

Thickness. $102 \mathrm{~m}$ at the type section.

Lithology. Units of interbedded micaceous, silty mudstones and sandstones alternate with coarsening-upwards units of coarse-grained sandstones and occasional conglomerates. Thin coal beds are recorded.

Fossils. Trace fossils and dinoflagellate cysts.

Depositional environment. Paralic, marginal marine to freshwater, possibly lagoonal, as indicated by palynomorphs, alternating with possible fan deltas (Sykes \& Brand 1976; Piasecki 1979).

Boundaries. The lower boundary is placed at the base of a prominent dark grey silty mudstone bed, overlying pebbly sandstones or a marked pebble lag capping the Kronen Member. The formation forms the top stratum of the sedimentary succession in Milne Land.

Distribution. Hartz Fjeld, Milne Land (Figs 1, 2b).

Chronostratigraphy. Hauterivian, on the basis of dinoflagellate cysts (Piasecki 1979).

\section{Wollaston Forland Group}

History. Erected by Surlyk (1978a).

Type area. Wollaston Forland (Fig. 1).

Thickness. Estimated to be up to $3 \mathrm{~km}$.

Lithology. Dominated by breccias, conglomerates, pebbly sandstones and dark sandy and silty mudstones of the Lindemans Bugt Formation, overlain by thinner conglomerates and sandstones, calcareous light grey and red mudstones of the Palnatokes Bjerg Formation. The lithologies of the group and its constituent formations and members are described in detail by Surlyk (1978a, 1984), Surlyk \& Korstgård (2013), Henstra et al. (2016) and Hovikoski et al. (2018).

Fossils. Ammonites, belemnites, bivalves and trace fossils at some levels.

Depositional environment. Marine fault-scarp talus, coalescent submarine fans forming slope aprons, basinfloor fans, and condensed mudstones over submerged half-graben crests.

Boundaries. The lower boundary is placed at the base of the lowest breccias, conglomerates and pebbly sandstones, overlying yellow sandstones of the Pelion Formation, dark mudstones of the Bernbjerg Formation, 
or crystalline basement with marked erosional and in some cases angular unconformity. The upper boundary may be unconformable or conformable, dependent on the structural setting, and is placed at the base of the Lower Cretaceous mudstones of the Brorson Halvø Group of Bjerager et al. (2020).

Distribution. Wollaston Forland, Kuhn $\varnothing$, Th. Thomsen Land, Hochstetter Forland and Store Koldewey. On Traill $\varnothing$, the group is only represented by the Valanginian Albrechts Bugt and Rødryggen Members of the Palnatokes Bjerg Formation (Figs 1, 2d, 2e).

Chronostratigraphy. Middle Volgian - Hauterivian, based on ammonites and bivalves.

Subdivision. The group is subdivided (from below) into the Lindemans Bugt and Palnatokes Bjerg Formations.

Key references. Vischer (1943), Maync (1947, 1949), Donovan (1953, 1964), Surlyk \& Clemmensen (1975), Surlyk (1975, 1978a, 1978c, 1984, 1989, 2003), Nøhr-Hansen (1993), Kelly et al. (1998), Alsen (2006), Alsen \& Mutterlose (2009), Pauly et al. (2012a, b, 2013), Surlyk \& Korstgård (2013), Möller et al. (2015), Henstra et al. (2016), Hovikoski et al. (2018), Bjerager et al. (2020).

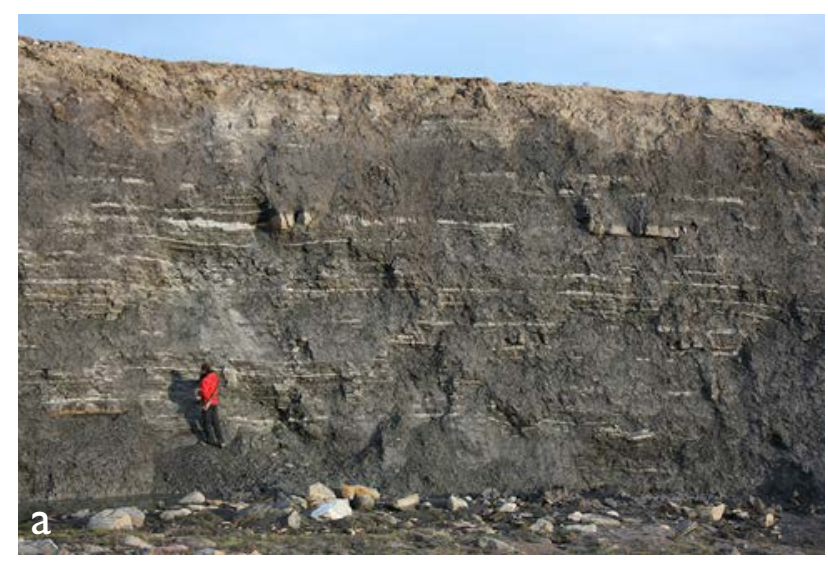

\section{Lindemans Bugt Formation}

History. Erected by Surlyk (1978a).

Type area. North-west Wollaston Forland (Fig. 1); see component members for the type sections.

Reference sections. Niesen (Surlyk 1978a, sections 15, 20, 22, 24, 34), Palnatoke Bjerg (Surlyk 1978a, sections 49, 50; Fig. 2e).

Thickness. Up to about $2 \mathrm{~km}$.

Lithology. Breccias, boulder, cobble and pebble conglomerates, pebbly sandstones, coarse-grained sandstones, dark silty or sandy mudstones.

Fossils. Ammonites, belemnites, the bivalve Buchia, plant fragments.

Depositional environment. Marine fault-scarp talus, slope apron, coalescent submarine fans, basin plain.

Boundaries. The lower boundary is the same as for the group. The upper boundary is placed at the base of the lowermost light grey mudstones and thin finegrained sandstones of the Palnatokes Bjerg Formation,

Fig. 94 Type section of the Laugeites Ravine Member (Lindemans Bugt Formation), Laugeites Ravine, Kuhn $\varnothing$ (Figs 1, 2e). The upper part of the member is shown in (a), the middle part in (b), In both exposures, the exposed section is about $10 \mathrm{~m}$ thick.

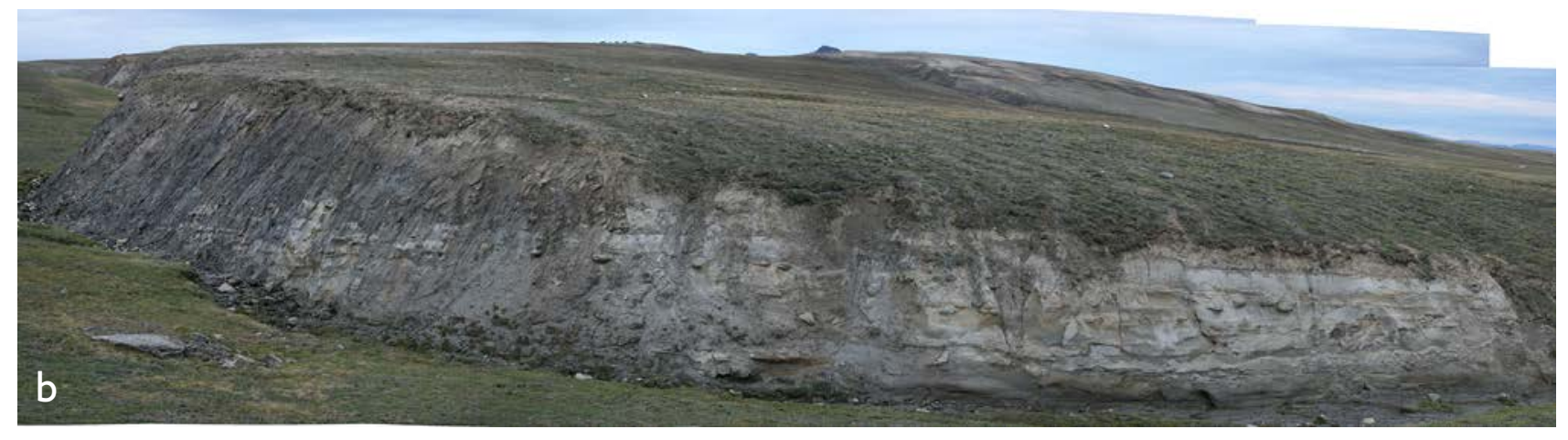




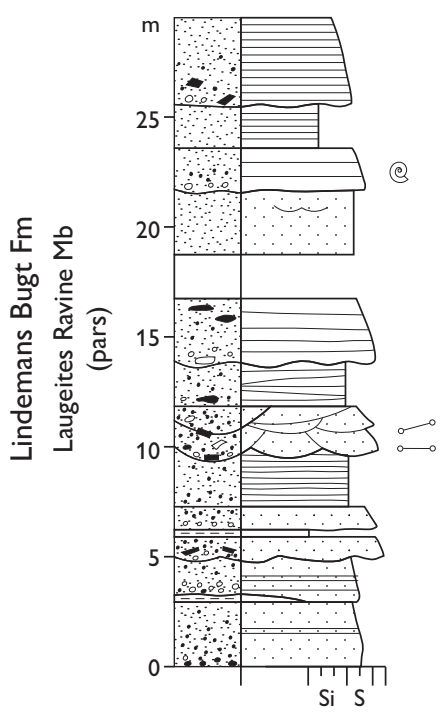

Fig. 95 Reference section of the Laugeites Ravine Member (Lindemans Bugt Formation), Laugeites Ravine, Kuhn $\varnothing$ (Figs 1, 2e). From Surlyk (1978a, section 7). For legend, see Fig. 7.

overlying the conglomerate-dominated Lindemans Bugt Formation.

Distribution. Wollaston Forland, Kuhn $\varnothing$, Th. Thomsen Land and Store Koldewey (Figs 2d, 2e).

Chronostratigraphy. Middle Volgian - middle upper Ryazanian, based on ammonites and bivalves.

Subdivision. The formation is subdivided (from below) into the Laugeites Ravine, Rigi and Niesen Members.

\section{Laugeites Ravine Member}

History. Erected by Surlyk (1978a).

Type section. Laugeites Ravine, southern Kuhn $\varnothing$ (Figs 1, $2 \mathrm{e}, 94)$.

Reference sections. Laugeites Ravine (Surlyk 1978a, sections 5, 7; 7447.9' N, 20³3.5'W), Niesen (Surlyk 1978a, section $20^{1}$; Figs $\left.2 \mathrm{e}, 95\right)$.

Thickness. At least $80 \mathrm{~m}$, possibly much more.

Lithology. Interlaminated dark silty-sandy mudstones and thin sandstones, pebbly sandstones and pebble conglomerates.

Fossils. Ammonites, belemnites, bivalves and plant fragments.
Depositional environment. Base-of-slope, fan fringe and interfan slope.

Boundaries. The lower boundary is placed where the lowest bed of interlaminated silty-sandy mudstones and thin sandstones, pebbly sandstones or pebble conglomerates overlie black, laminated, better sorted and finer grained mudstones of the Bernbjerg Formation. The upper boundary is placed at the base of the lowermost cobble or boulder conglomerate bed referred to the Rigi Member.

Distribution. Wollaston Forland and Kuhn $\varnothing$ (Figs 1, 2e).

Chronostratigraphy. Middle-upper Volgian, based on ammonites and bivalves.

\section{Rigi Member}

History. Erected by Surlyk (1978a).

Type area. North-west slopes of the Palnatoke Bjerg and Niesen mountains, Wollaston Forland (Figs 1, 2e).

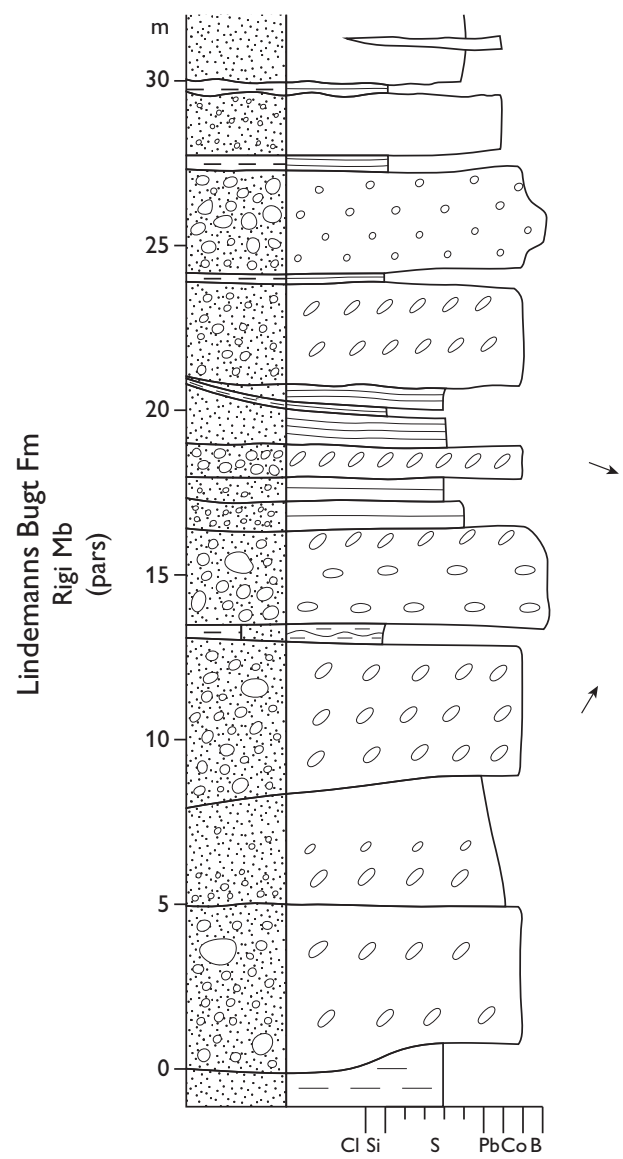

Fig. 96 Reference section from the type area of the thickly developed Rigi Member (Lindemans Bugt Formation) at the Niesen mountain, Wollaston Forland (Figs 1, 2e). From Surlyk (1978a, section 22). For legend, see Fig. 7. 
Reference sections. Niesen, (Surlyk 1978a, sections 15, 22), Palnatoke Bjerg (Surlyk 1978a, sections 30-34, 49, 50; Figs 2e, 96, 97).

Thickness. Estimated to be about $2 \mathrm{~km}$.

Lithology. Breccias, conglomerates, pebbly and coarsegrained sandstones.
Fossils. Ammonites, belemnites, bivalves and plant fragments.

Depositional environment. Fault-scarp talus, slope apron, coalescent submarine fans and basin-floor fans.

Boundaries. The lower boundary is placed where the member unconformably overlies crystalline basement rocks, where the lowest cobble or boulder conglomerate bed overlies interbedded dark mudstones and
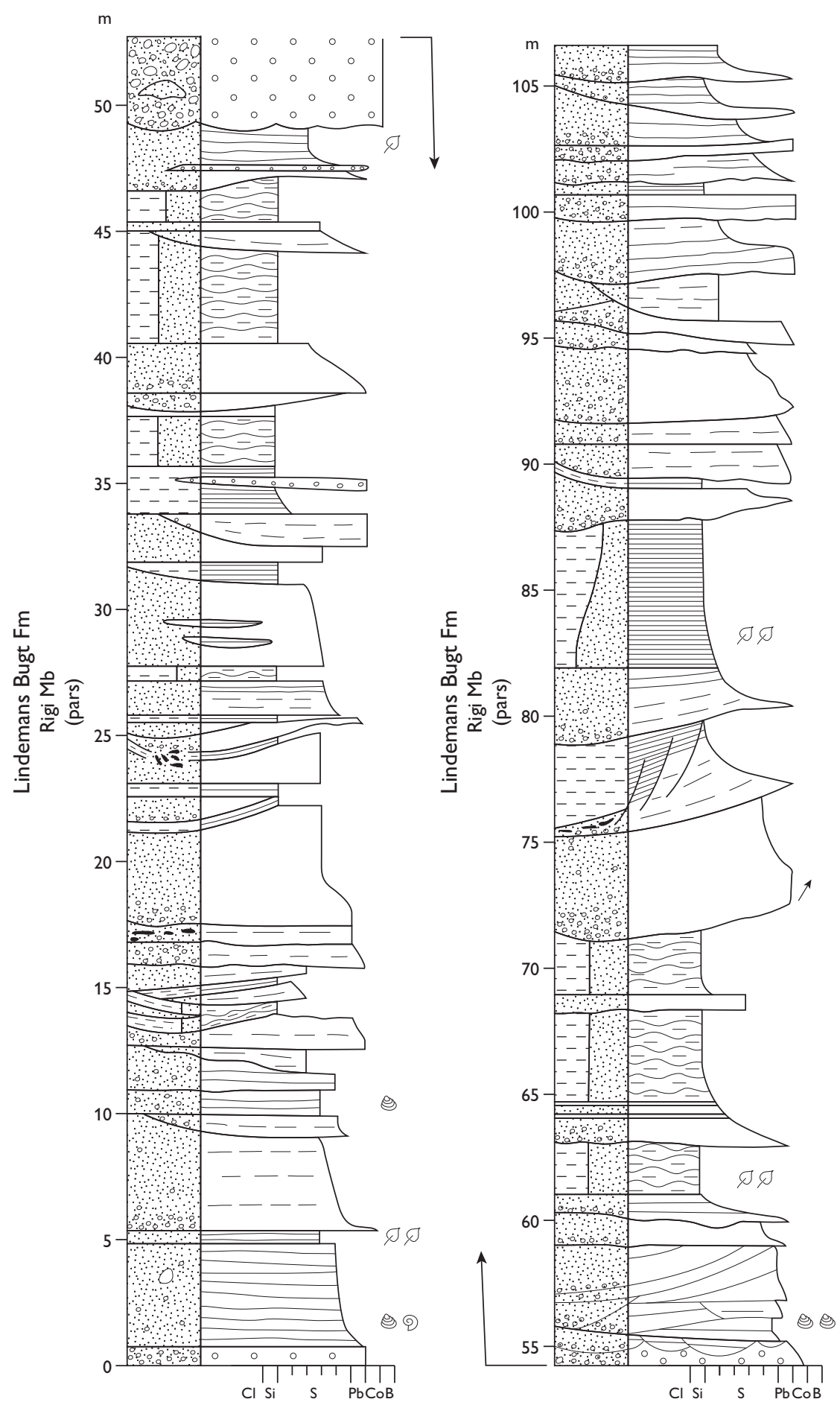

Fig. 97 Reference section from the type area of the thickly developed Rigi Member (Lindemans Bugt Formation), Palnatoke Bjerg, Wollaston Forland (Figs 1, 2e). From Surlyk (1978a, section 34). For legend, see Fig. 7. 
sandstones of the Laugeites Ravine Member, or where the base of the conglomerate-dominated member rests unconformably on yellow sandstones of the Pelion Formation or black mudstones of the Bernbjerg Formation. The upper boundary coincides with the upper boundary of the formation.

Distribution. Wollaston Forland, Th. Thomsen Land, Kuhn $\varnothing$ (Figs 1, 2e).

Chronostratigraphy. Middle Volgian - upper Ryazanian, based on ammonites and bivalves.

\section{Niesen Member}

History. Erected by Surlyk (1978a).

Type section. Niesen, Wollaston Forland, 74³9.4' N, 20³1.2'W (Surlyk 1978a, section 203; Figs 1, 2e, 98).

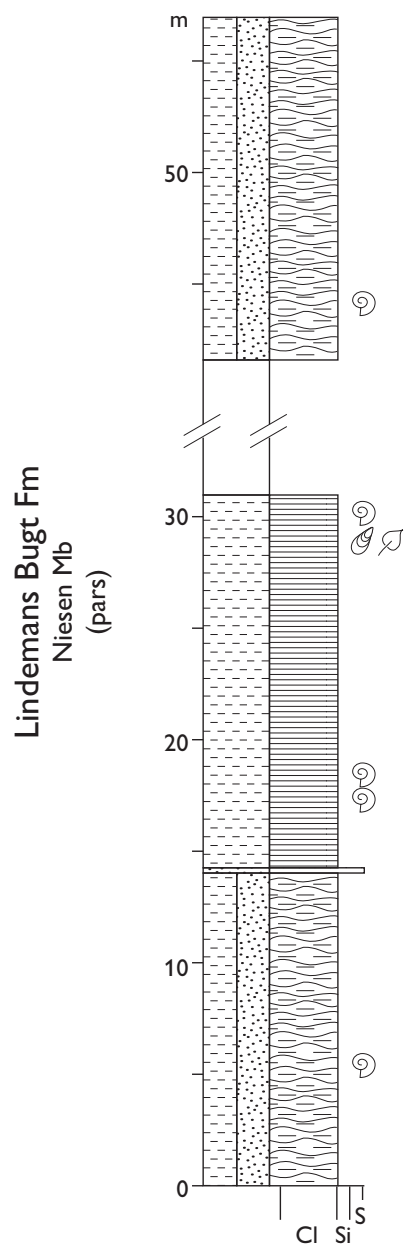

Fig. 98 Type section of the Niesen Member (Lindemans Bugt Formation), Niesen, Wollaston Forland (Figs 1, 2e). From Surlyk (1978a, section $20^{3}$ ). For legend, see Fig. 7 .
Reference section. Store Koldewey (for details, see Bjerager et al. 2020; Fig. 1).

Thickness. Up to 200 m, wedges out towards the east.

Lithology. Dark mudstones, interlaminated mudstones and fine-grained sandstones.

Fossils. Ammonites, belemnites, bivalves and plant fragments.

Depositional environment. Base-of-slope and basin plain.

Boundaries. The lower boundary is placed at the base of dark mudstones and other fine-grained lithologies, overlying the conglomerate-dominated Rigi Member. The upper boundary is placed where dark mudstones are succeeded by the conglomeratic Young Sund Member or by light grey mudstones of the Albrechts Bugt Member, both belonging to the upper Ryazanian Hauterivian Palnatokes Bjerg Formation.

Distribution. Wollaston Forland, Store Koldewey (Figs 1, 2d, 2e).

Chronostratigraphy. On Wollaston Forland, upper Volgian - upper Ryazanian, based on ammonites and bivalves. Lower-upper Ryazanian on Store Koldewey based on ammonites and dinoflagellates.

\section{Palnatokes Bjerg Formation History. Erected by Surlyk (1978a).}

Type section. Niesen, Wollaston Forland, $74^{\circ} 38.3^{\prime} \mathrm{N}$, $20^{\circ} 29.8^{\prime} \mathrm{W}$ (Figs 1, 2e, 99).

Reference sections. Eastern Kuhn $\varnothing$ (Surlyk 1978b, sections 10, 13), Niesen (Surlyk 1978a, section 18), Rødryggen (Surlyk 1978a, sections 53, 54), Store Koldewey (Bjerager et al. 2020; Figs 1, 2e).

Thickness. About $600 \mathrm{~m}$ on Wollaston Forland, wedging out to the east to $25-30 \mathrm{~m}$. Up to $70 \mathrm{~m}$ on Store Koldewey.

Lithology. Conglomerates, pebbly sandstones, sandstones, interlaminated mudstones and sandstones, dark mudstones, light grey mudstones with abundant calcareous concretions and concretionary layers, yellow and dark red mudstones.

Fossils. Bivalves and belemnites locally very common, ammonites relatively rare. 

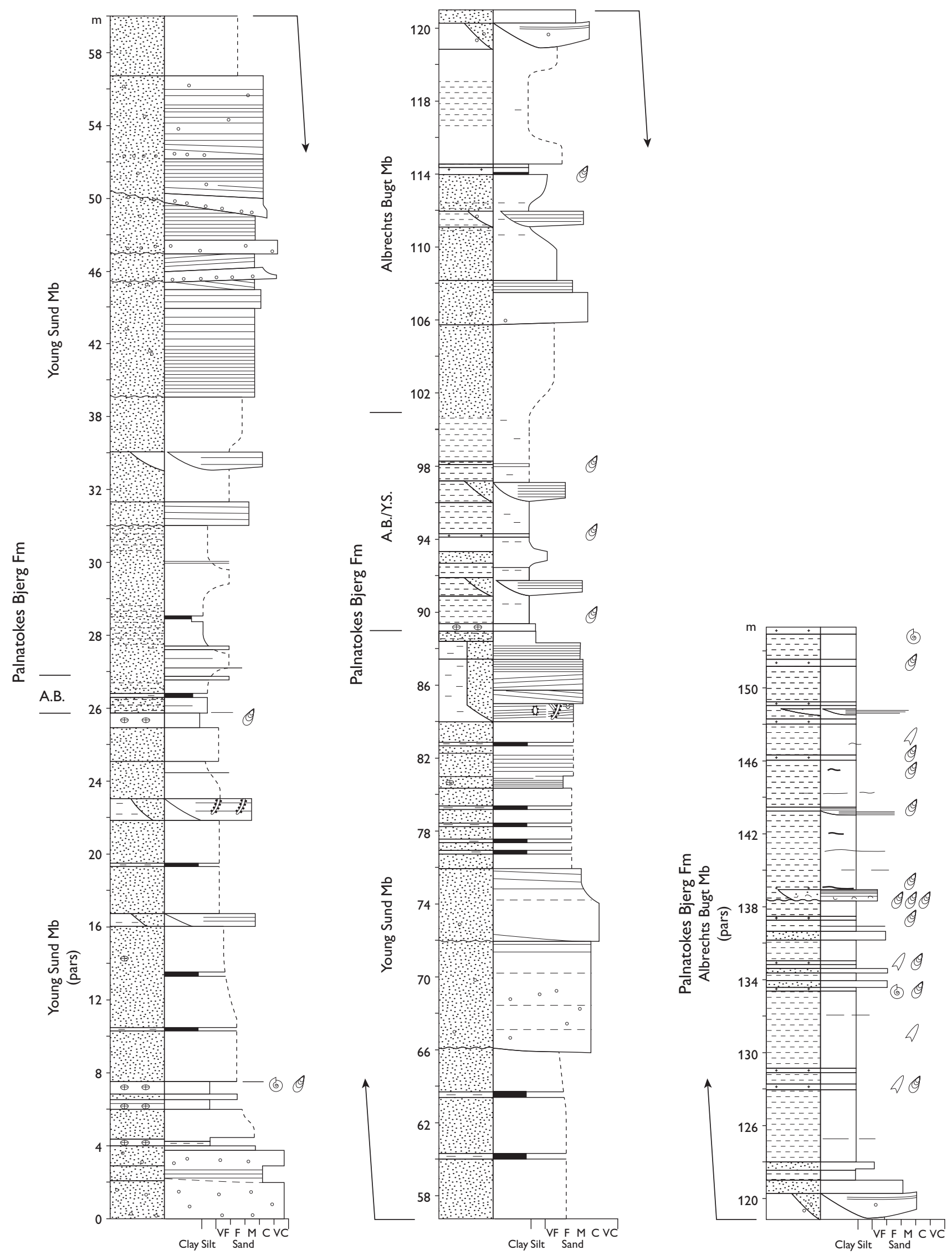

Fig. 99 Type section of the Palnatokes Bjerg Formation and reference section of the Young Sund Member of this formation at the Niesen mountain, Wollaston Forland (Figs 1, 2e). A.B.: thin tongues of the Albrechts Bugt Member. A.B./Y.S.: transitional Young Sund and Albrechts Bugt Members. From Hovikoski et al. (2018, fig. 6). For legend, see Fig. 7. 
Depositional environment. Slope apron, basin-floor fan, basin plain, submerged intrabasinal highs formed over half-graben crests.

Boundaries. On Wollaston Forland, the lower boundary is placed where thinly interbedded light grey mudstones and fine-grained sandstones overlie the conglomeratedominated Lindemans Bugt Formation. Where the formation rests on dark mudstones of the Niesen Member of the Lindemans Bugt Formation, the boundary is placed at the base of mainly light grey mudstones with more concretionary horizons. On Store Koldewey, the lower boundary is placed at the base of a varicoloured greyish-reddish conglomerate bed where it overlies crystalline basement, yellow sandstones of the Pelion Formation, or grey muddy sandstones of the Lindemans Bugt Formation. The Palnatokes Bjerg Formation is overlain by dark Barremian-Albian mudstones of the Stratumbjerg Formation of Bjerager et al. (2020). This boundary is typically an erosional unconformity but may be locally conformable on Wollaston Forland and Store Koldewey (Bjerager et al. 2020).

Distribution. Wollaston Forland and Kuhn $\varnothing$. Isolated outliers on Traill $\varnothing$, Hochstetter Forland and Store Koldewey (Figs 1, 2d, 2e).

Chronostratigraphy. On Wollaston Forland, uppermost Ryazanian (Bojarkia mesezhnikovi ammonite zone) Hauterivian (Simbirskites beds), based on ammonites and bivalves. On Store Koldewey, uppermost Ryazanian (Bojarkia mesezhnikovi ammonite zone) - lowermost upper Barremian based on ammonites, belemnites, bivalves, nannofossils and dinoflagellates.

Subdivision. The formation is subdivided into the Young Sund, Falskebugt, Albrechts Bugt and Rødryggen Members in the Wollaston Forland and Kuhn $\varnothing$ areas, and into the Midter Gneisnæs and Ravn Pynt Members on Store Koldewey.

\section{Young Sund Member \\ History. Erected by Surlyk (1978a).}

Type section. Stratumbjerg on the southern side of the Cardiocerasdal valley, south-west Wollaston Forland, $74^{\circ} 26.6^{\prime} \mathrm{N}, 20^{\circ} 13.7^{\prime} \mathrm{W}$ (Surlyk 1978a, section 37; Figs 1, $2 \mathrm{e}, 100)$.

Reference section. Niesen, Wollaston Forland (Figs 2e, 99).

Thickness. The original maximum thickness is estimated at about $600 \mathrm{~m}$. Less than $50 \mathrm{~m}$ at the type locality.

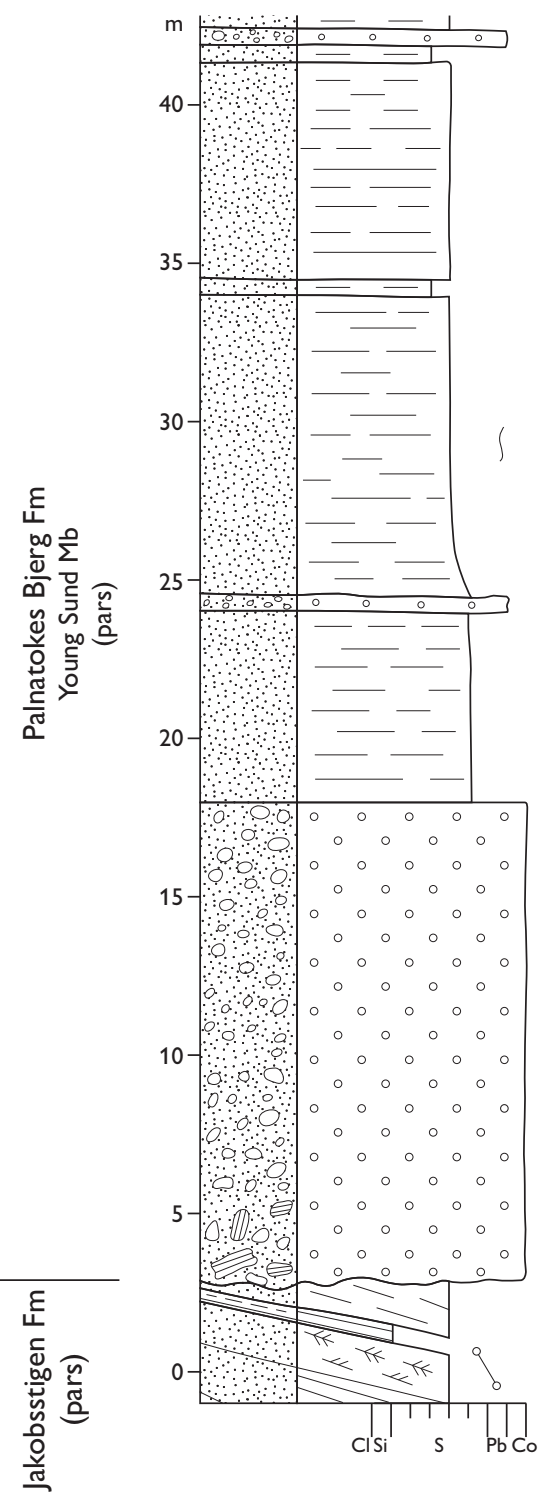

Fig. 100 Type section of the Young Sund Member at Stratumbjerg, southern side of Cardiocerasdal, Wollaston Forland (Figs 1, 2e). From Surlyk (1978a, section 37). For legend, see Fig. 7.

Interfingers with the Albrechts Bugt Member through a thickness of about 250-300 m in northern Wollaston Forland (Fig. 99), and about $150 \mathrm{~m}$ on Store Koldewey.

Lithology. Conglomerates with subordinate breccias, coarse- and medium-grained sandstones with thin pebble beds. The clasts in the conglomerates are normally well-rounded quartzites, gneisses and amphibolites. In the lower levels of the member, the conglomerates and breccias contain sandstone and heterolith blocks or rafts derived from the Pelion and Jakobsstigen Formations; clasts of light grey mudstone and calcareous concretions, both from the Albrechts Bugt Member, are also common.

Fossils. Bivalves and belemnites. 


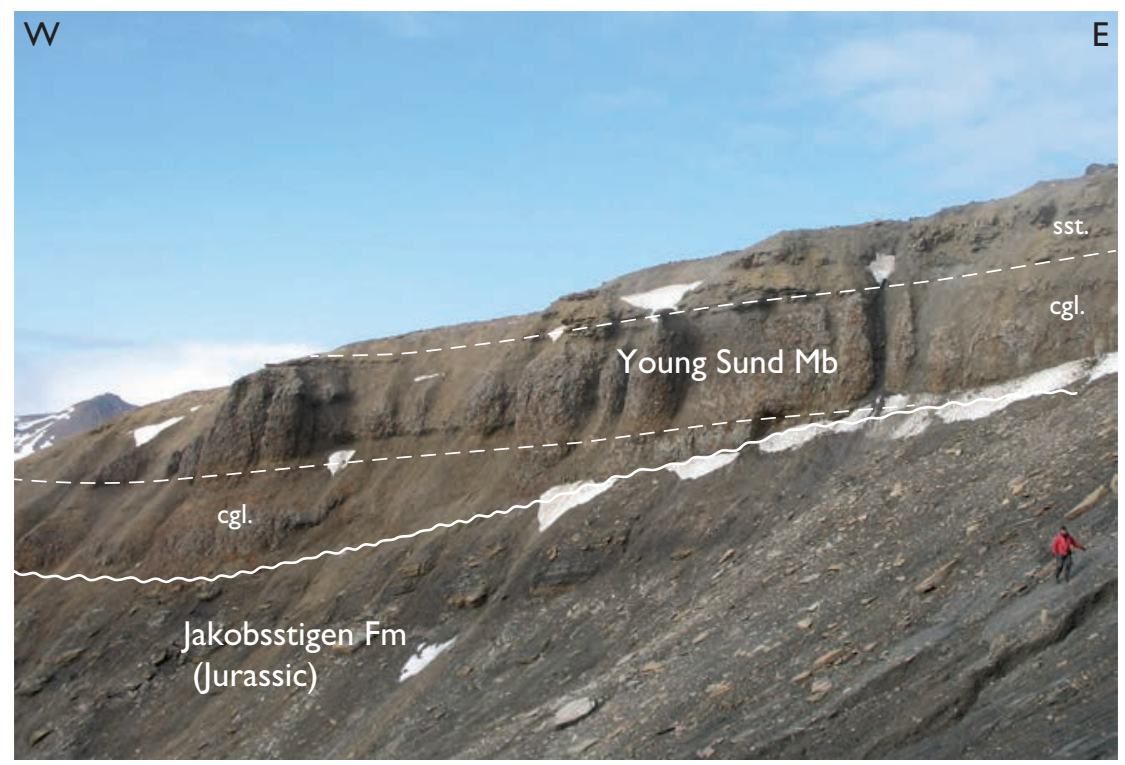

Fig. 101 Submarine gravity-flow conglomerates of the Young Sund Member (Palnatokes Bjerg Formation) at the type section, erosionally overlying Upper Jurassic sandstones of the Jakobsstigen Formation. Stratumbjerg, south-western Wollaston Forland (Figs 1, 2e), figure (right) for scale.

Depositional environment. Slope apron and basin-floor fan.

Boundaries. In south-west Wollaston Forland, the lower boundary is placed at an angular unconformity at the base of the lowest conglomerates overlying yellow sandstones of the Pelion Formation, mudstones of the Bernbjerg Formation, or sandstones and heteroliths of the Jakobsstigen Formation (Figs 100, 101). Where it overlies the Rigi Member of the Lindemans Bugt Formation, it can be distinguished by its large content of reworked clasts of sedimentary rocks, notably light grey mudstones and concretions of the penecontemporaneous Albrechts Bugt Member. The upper boundary is unconformable and placed at the base of dark Barremian-Albian mudstones with intercalated sandstones of the Stratumbjerg Formation of Bjerager et al. (2020). The member interfingers laterally to the east with the Albrechts Bugt Member and in transitional sections, the boundary is placed at the $50 \%$ cut-off position between conglomerates characterising the Young Sund Member and mudstones or fine-grained sandstones typical of the Albrechts Bugt Member.

Distribution. Western Wollaston Forland, Clavering $\varnothing$ (Figs 1, 2e).

Chronostratigraphy. Uppermost Ryazanian - Valanginian, based on ammonites and bivalves.

\section{Falskebugt Member}

History. Erected by Surlyk (1978a).
Type locality. Western slope of Falkebjerg, north-eastern Wollaston Forland, $74^{\circ} 34.9^{\prime}$ N. 19²0.9'W (Figs 1, 2e, 102).

Thickness. About 40-50 m.

Lithology. Conglomerates and coarse-grained sandstones, which may contain reworked Albrechts Bugt Member sediments (Fig. 102).

Fossils. Bivalves, brachiopods.

Boundaries. Rests on Caledonian crystalline basement rocks and interfingers to the west with Albrechts Bugt Member mudstones. In transitional sections, the boundary between the two members is placed at the 50\% cut-off position between the conglomerates and sandstones of the Falskebugt Member and the mudstones of the Albrechts Bugt Member. The upper boundary is unconformable and is placed at the base of the dark Barremian-Albian mudstones of the Stratumbjerg Formation of Bjerager et al. (2020).

Distribution. North-east Wollaston Forland (Figs 1, 2e).

Chronostratigraphy. Valanginian-Hauterivian(?), based on bivalves and ammonites. Piasecki et al. (2020) have recently suggested that the uppermost levels of this member may interfinger with the Stratumbjerg Formation, though this interpretation is based primarily on a poorly exposed area. If confirmed, however, this relationship would indicate a Barremian age for the uppermost Falskebugt Member. 


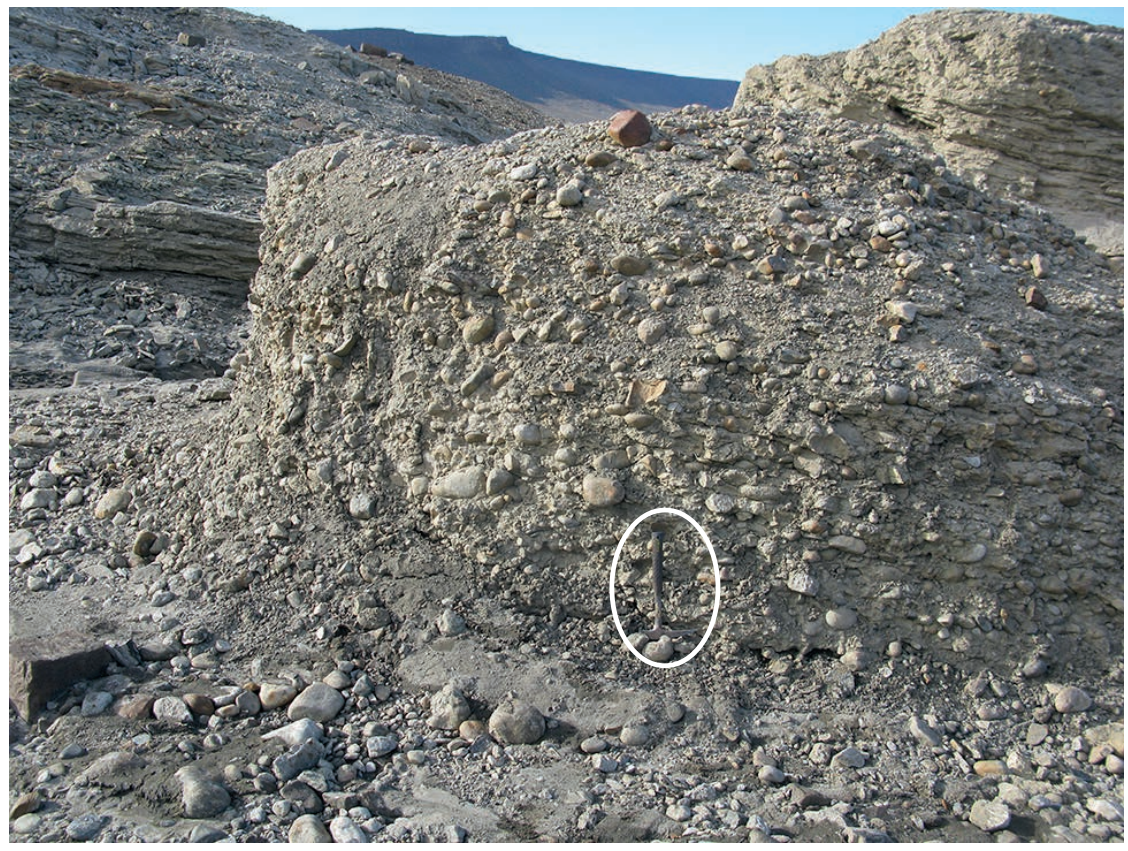

Fig. 102 Type locality of the Falskebugt Member (Lindemans Bugt Formation), hammer (encircled) for scale. No section measured due to lack of reliable continuous exposure. Western slope of the Falkebjerg mountain, north-eastern Wollaston Forland (Figs 1, 2e). Photograph by Jørgen Bojesen-Koefoed.

\section{Albrechts Bugt Member \\ History. Erected by Surlyk (1978a).}

Type section. Rødryggen, north-central Wollaston Forland, $74^{\circ} 32.7^{\prime} \mathrm{N}, 1^{\circ} 50.9^{\prime} \mathrm{W}$ (Figs $\left.1,2 \mathrm{e}, 103,104\right)$.

Reference sections. Perisphinctes Ravine, Wollaston Forland (Surlyk 1978a, section 10), eastern Kuhn Ø (Surlyk 1978a, section 13), Niesen, Wollaston Forland (Surlyk 1978a, section 18), Rødryggen, Wollaston Forland (Surlyk 1978a, sections 53, 54; Figs 2e, 99).

Thickness. About $300 \mathrm{~m}$ in northern Wollaston Forland where it interfingers with the most fine-grained parts of the Young Sund Member. Thins to the east to about $30 \mathrm{~m}$.

Lithology. Sandy, light-grey to yellowish mudstones with abundant calcareous concretions, nodules and layers.

Fossils. Ammonites, bivalves, belemnites. brachiopods, calcareous nannofossils and trace fossils.

Depositional environment. Basin floor, hanging-wall dip slope and submerged intrabasinal highs formed over fault-block crests.

Boundaries. The lower boundary is placed at the base of light grey mudstones, overlying darker Niesen Member mudstones, which contain much fewer concretions, or conglomerates and sandstones of the Rigi Member. In southern and eastern Wollaston Forland and eastern Kuhn $\varnothing$, the boundary is placed at the base of light grey mudstones, overlying black mudstones of the Bernbjerg Formation with angular or erosional unconformity. The member interfingers laterally with conglomerates and sandstones of the Young Sund Member to the west and with conglomerates and sandstones of the Falskebugt Member to the east; in such situations, the member boundaries are defined at the $50 \%$ cut-off point between the respective lithologies. The upper boundary is placed at the base of red mudstones of the Rødryggen Member and is sharp or transitional. In the latter case, the base of the lowest red mudstone defines the boundary. The upper boundary is unconformable in some areas and placed at the base of dark mudstones of the Stratumbjerg Formation of Bjerager et al. (2020).

Distribution. Western, central and south-west Wollaston Forland and probable outliers south of Falskebugt, on eastern Kuhn $\varnothing$ and eastern Hochstetter Forland. Small outliers occur on north-east Traill $\varnothing$ (Figs 1, 2e).

Chronostratigraphy. Uppermost Ryazanian - Hauterivian, based on ammonites and bivalves.

\section{Rødryggen Member \\ History. Erected by Surlyk (1978a).}

Type section. Rødryggen, north-central Wollaston Forland, $74^{\circ} 32.7^{\prime} \mathrm{N}, 19^{\circ} 50.9^{\prime} \mathrm{W}$ (Surlyk 1978a, section 54; Figs 1, 2e, 103, 104). 


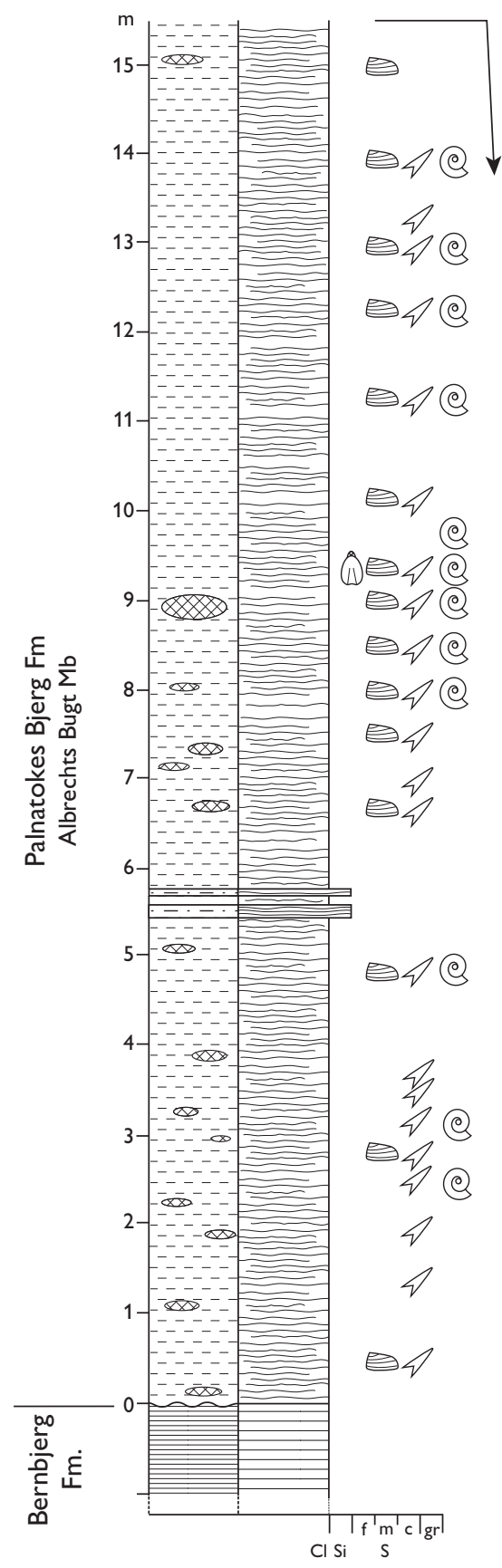

Fig. 103 Type sections of the Albrechts Bugt and Rødryggen Members at Rødryggen, Wollaston Forland (Figs 1, 2e). From Alsen (2006, fig. 28 and appendix 1.4). For legend, see Fig. 7.

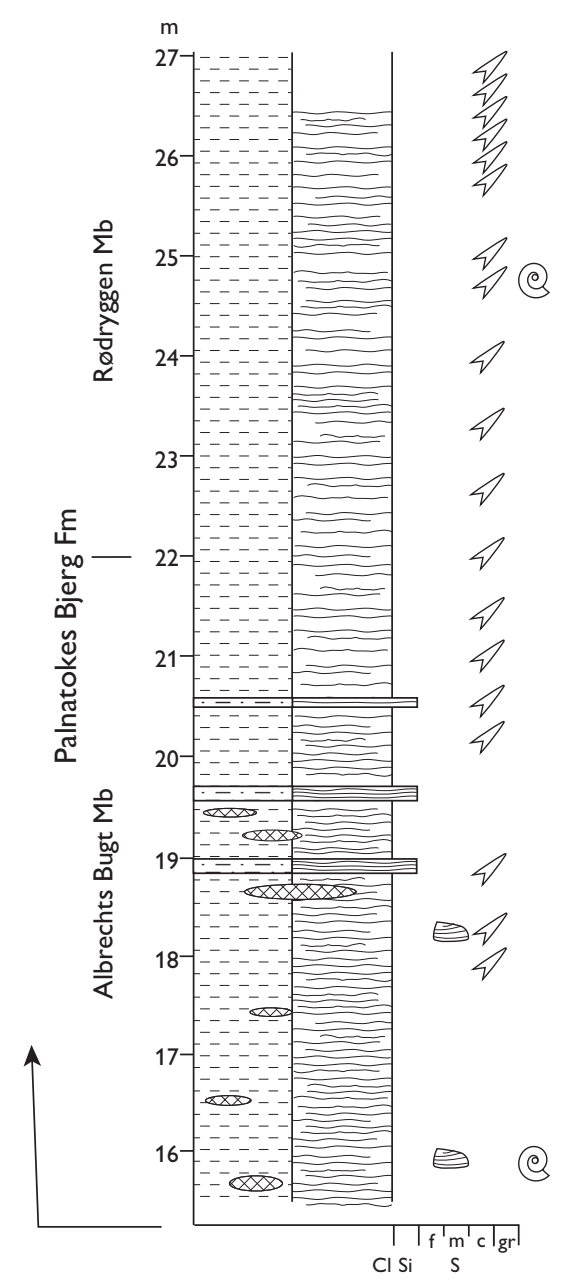

Reference sections. Rødryggen, central Wollaston Forland (Surlyk 1978a, section 53), and Stratumbjerg, south-west Wollaston Forland (Figs 1, 2e).

Thickness. Up to about $13 \mathrm{~m}$.

Lithology. Red mudstones with intercalated fine sandy yellow mudstones (Figs 104, 105).

Fossils. Bivalves, brachiopods, ammonites, belemnites, echinoids, crinoids and trace fossils.
Depositional environment. Submerged intrabasinal highs formed over fault block crests.

Boundaries. The lower boundary with the underlying Albrechts Bugt Member is placed at the base of the lowermost red mudstone bed. In some areas, the lower boundary is placed at an unconformity on black mudstones of the Bernbjerg Formation. The upper boundary is placed at the base of the unconformably overlying dark mudstones of the Stratumbjerg Formation of Bjerager et al. (2020). 


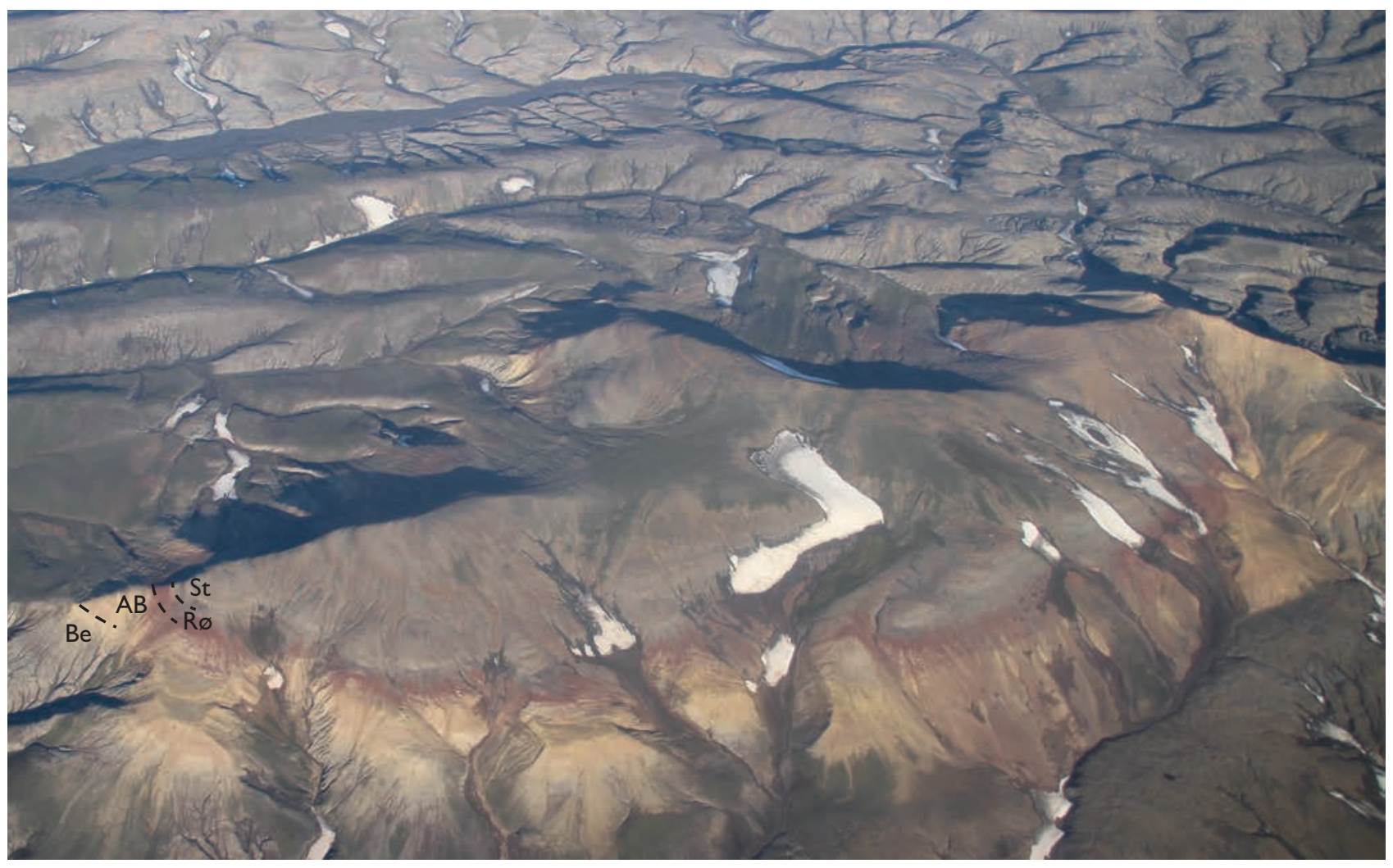

Fig. 104 Oblique aerial photograph of the Rødryggen ridge, Wollaston Forland (Figs 1, 2e), viewed towards the south-east, showing mudstones of the Bernbjerg Formation (Be) overlain by the Palnatokes Bjerg Formation comprising light-coloured calcareous mudstones of the Albrechts Bugt Member (AB), followed by red mudstones of the Rødryggen Member (Rø, c. 10 thick). The Palnatokes Bjerg Formation is succeeded by dark mudstones of the Stratumbjerg Formation (St). Dark mudstones in the badlands in the background belong to the Bernbjerg Formation.

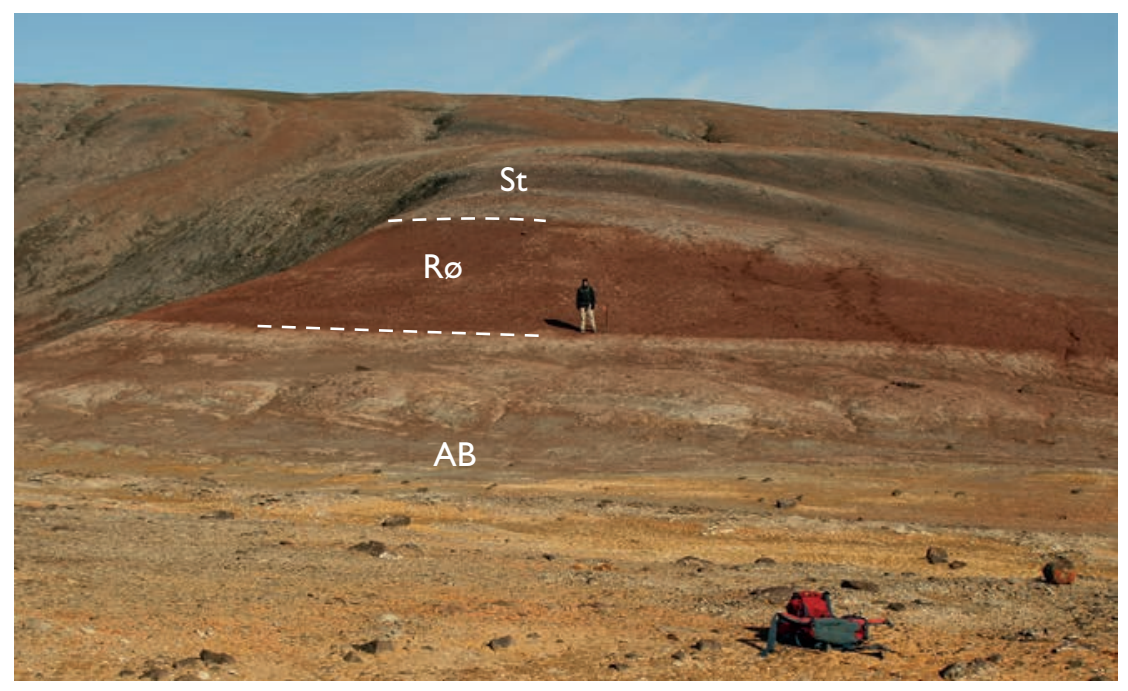

Fig. 105 The type locality for the Albrechts Bugt Member (AB) and the Rødryggen Member (Rø), both Palnatokes Bjerg Formation. Succeeded by dark mudstones of the Stratumbjerg Formation (St). Rødryggen, Wollaston Forland (Figs 1, 2e).

Distribution. Stratumbjerg in south-west Wollaston Forland, central Wollaston Forland, eastern Kuhn $\varnothing$, small outliers in eastern Hochstetter Forland and north-east Traill $\varnothing$ (Figs 1, 2e).
Chronostratigraphy. Upper Ryazanian - upper Valanginian on Traill $\varnothing$, Hauterivian in the Wollaston Forland area, based on ammonites and bivalves. 


\section{Midter Gneisnaes Member}

History. Erected by Bjerager et al. (2020) as a new member of the Palnatokes Bjerg Formation to encompass very coarse siliciclastic sediments in the Store Koldewey area that were earlier assigned to the 'Aucella conglomerate' and the Cape Hamburg Formation by Koch (1929). The latter name was abandoned by Surlyk (1978a), due to lack of stratigraphic information.

Type section. Trækpasset, Store Koldewey, $76^{\circ} 09.6^{\prime} \mathrm{N}$, $18^{\circ} 34.4^{\prime} \mathrm{W}$, where the geometry of the member is well exposed (Figs 2d, 106, 107).

Reference section. Midter Gneisnæs, Store Koldewey (Figs $1,2 d)$.

Thickness. At least $30 \mathrm{~m}$ at Midter Gneisnæs and $48 \mathrm{~m}$ at Trækpasset on Store Koldewey, within the axes of depositional channels or gullies, thinning out to less than $1 \mathrm{~m}$ at channel margins. Up to a few metres thick elsewhere on Store Koldewey.

Lithology. The thicker, axial successions consist of coarse conglomerates and breccias, few fossil-rich pebble conglomerates (Fig. 107), coarse- and medium-grained sandstones with thin pebble beds and subordinate mudstone beds. At Ravn Ravine, and at channel margins, the member is about one metre thick and consists of muddy and sandy conglomerates with abundant fossils, predominantly Buchia bivalves.

Fossils. Bivalves, belemnites and ammonites are common in certain intervals.

Depositional environment. Submarine gully/channel, and channel margins, submarine fault-scarp slope apron and fan.

Boundaries. The lower boundary is placed at the base of a varicoloured greyish-reddish conglomerate, overlying crystalline basement or yellow sandstones of the Pelion Formation with an erosional contact. The upper boundary is placed at the base of grey mudstones of the Ravn Pynt Member, which in places has a sandy basal part, or the member is unconformably overlain by yellowish grey sandstones of the basal Stratumbjerg Formation (Bjerager et al. 2020).

Distribution. Store Koldewey (Figs 1, 2d).

Chronostratigraphy. The age of the lower part is not well constrained. The middle and upper parts of the member are assigned to the uppermost Ryazanian - upper Valanginian based on ammonites, belemnites, bivalves, palynomorphs and nannoplankton.

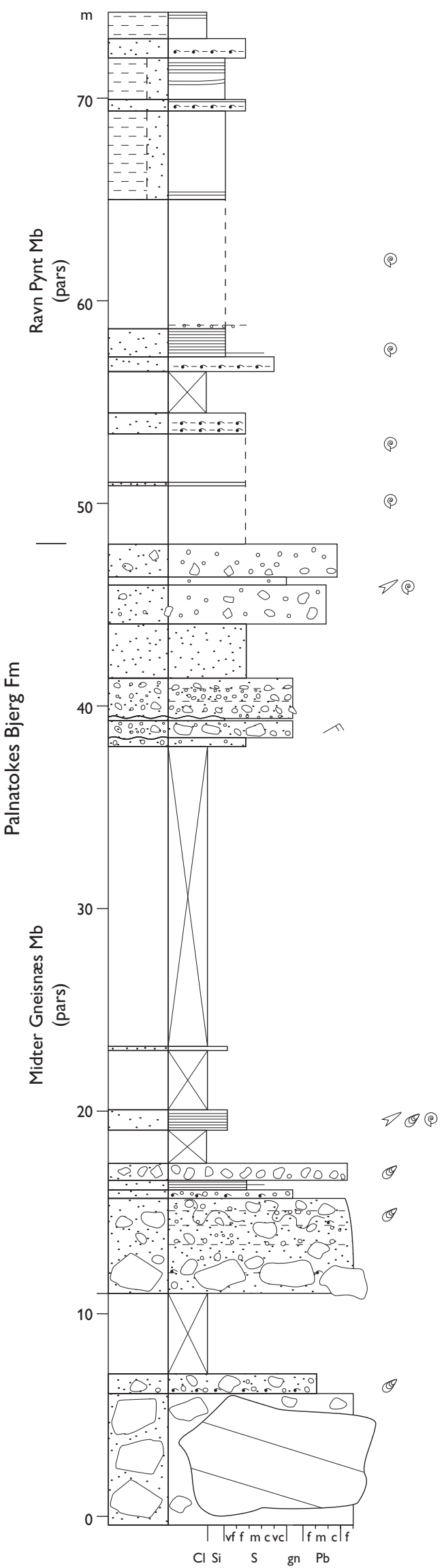

Fig. 106 Type section of the Midter Gneisnæs Member at Trækpasset, Store Koldewey (Figs 1, 2d). From Bjerager et al. (2020). For legend, see Fig. 7. 


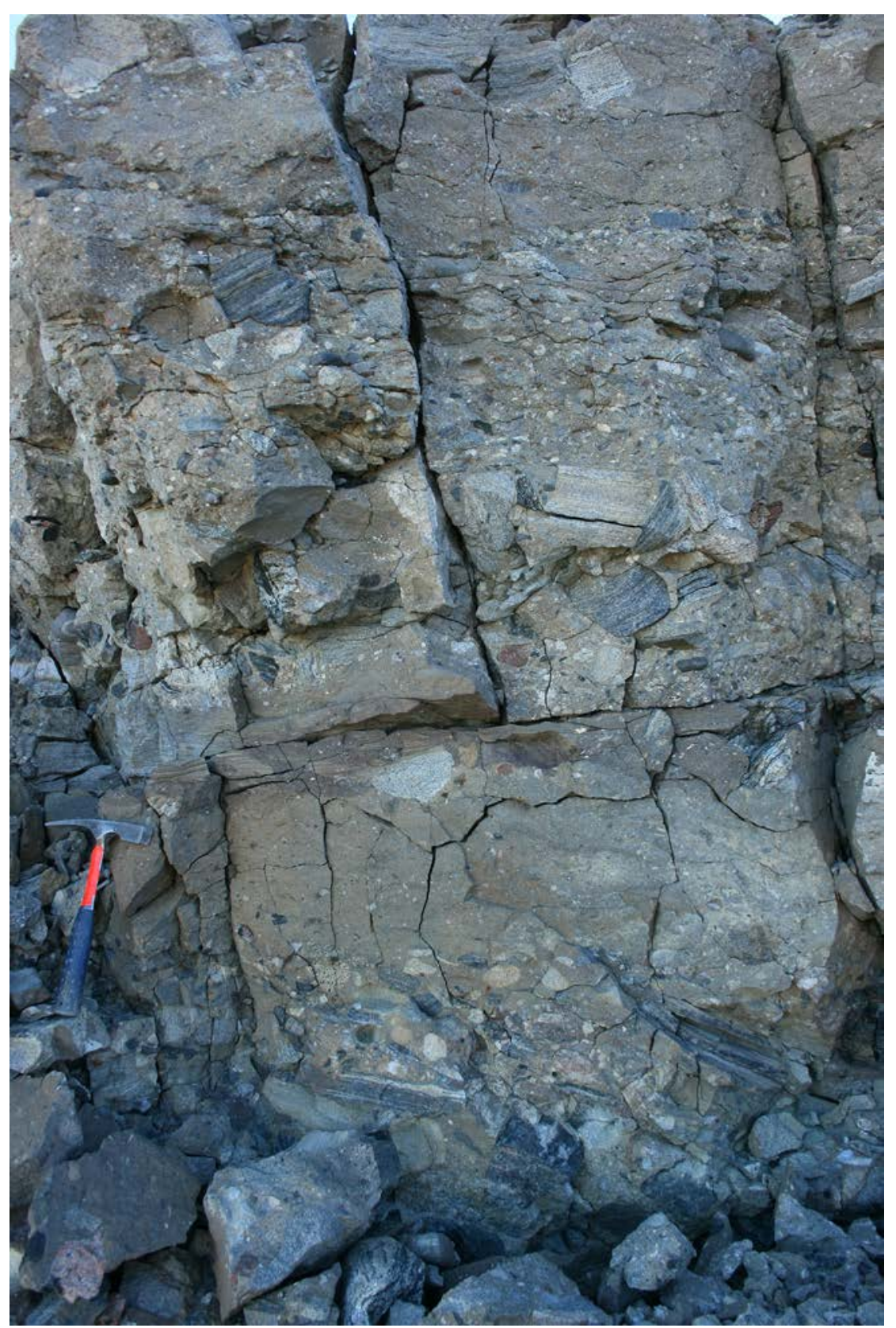

Fig. 107 Midter Gneisnæs Member at the type section, showing stacked conglomerate - pebbly sandstone beds. Trækpasset, Store Koldewey (Figs 1, 2d).

\section{Ravn Pynt Member}

History. Erected by Bjerager et al. (2020) for the upper part of the Palnatokes Bjerg Formation on Store Koldewey (Fig. 1).

Type section. Ravn Pynt, Store Koldewey, $76^{\circ} 08.9^{\prime} \mathrm{N}$, 18³3.2'W (Bjerager et al. 2020; Fig. 2d).

Reference section. Ravn Ravine, Store Koldewey (Figs 1, 2d).

Thickness. 10-100 m thick.

Lithology. Bioturbated grey silty and sandy mudstones with thin sandstone beds.
Fossils. Large inoceramid bivalves and belemnites common, rare ammonites, common wood fragments and dinoflagellates. Trace fossils include Zoophycos, Nereites, Diplocraterion, Palaeophycus and rare Paleodictyon.

Depositional environment. Deep-water slope gully and slope.

Boundaries. The lower boundary is poorly exposed at the type section but is well exposed in the reference section at Ravn Ravine, where it is placed at the base of a grey mudstone bed, overlying a fossiliferous conglomerate of the Midter Gneisnæs Member (Palnatokes Bjerg Formation). In the type section, the upper boundary is placed at the erosional base of a pebbly and fossil-rich 
sandstone bed of the basal Stratumbjerg Formation. In the reference section at Ravn Ravine, the upper boundary is placed at the base of dark grey laminated mudstones of the Stratumbjerg Formation (Bjerager et al. 2020).

Distribution. Store Koldewey (Figs 1, 2d).

Chronostratigraphy. Lower Valanginian - lower Barremian, based on ammonites, belemnites, bivalves, dinoflagellates and nannoplankton.

\section{Acknowledgements}

The comprehensive stratigraphic revision presented here results from the work of the senior author and a number of colleagues and graduate students since the late 1980s. We are grateful for generous economic support from the Danish Natural Science Research Council, the Carlsberg Foundation, Norsk Hydro, Statoil, Saga Petroleum, the Norwegian Petroleum Directorate, Amoco, Conoco and BP. We acknowledge the late J.H. Callomon for assistance in determination of ammonites from critical stratigraphic levels. We are very grateful to Jette Halskov for artwork. We thank the reviewers Snorre Olaussen and Harald Brekke for penetrating and painstaking, yet constructive comments. Special thanks go to GEUS scientific editor J.R. Ineson, not only for comments on an early manuscript version but also for his dedicated editorial work on the final manuscript.

\section{Additional information}

Funding

Economic support from the Danish Natural Science Research Council, the Carlsberg Foundation, Norsk Hydro, Statoil, Saga Petroleum, the Norwegian Petroleum Directorate, Amoco, Conoco and BP.

\section{Author contributions}

FS planned, structured and wrote the integrated manuscript, in the latter stages with the assistance of PA. All authors, to varying degrees, contributed with primary data and initial texts to the description of individual lithostratigraphic units, and reviewed relevant parts of the final manuscript prior to submission. 


\section{References}

Ahokas, J.M., Nystuen, J.P. \& Martinius, A.W. 2014: Stratigraphic signatures of punctuated rise in relative sea-level in an estuary-dominated heterolithic succession: Incised valley fills of the Toarcian Ostreaelv Formation, Neill Klinter Group (Jameson Land, East Greenland). Marine and Petroleum Geology 50, 103-129. https://doi.org/10.1016/j. marpetgeo.2013.11.001

Aldinger, H. 1935: Geologische Beobachtungen im Oberen Jura des Scoresbysundes (Ostgrönland). Meddelelser om Grønland 99, 128 pp.

Alsen, P. 2006. The Early Cretaceous (Late Ryazanian - Early Hauterivian) ammonite fauna of North-East Greenland: taxonomy, biostratigraphy, and biogeography. Fossils and Strata 53, 229 pp.

Alsen, P. \& Mutterlose, J. 2009: The early Cretaceous of North-East Greenland: A crossroads of belemnite migration. Palaeogeography, Palaeoclimatology, Palaeoecology 280, 168-182. https://doi. org/10.1016/j.palaeo.2009.06.011

Alsen, P. \& Piasecki, S. 2018: Biostratigraphy of the Hareelv Formation (Upper Jurassic) in the Blokelv-1 core, Jameson Land, central East Greenland. In: Ineson, J. \& Bojesen-Koefoed, J.A. (eds): Petroleum geology of the Upper Jurassic - Lower Cretaceous of East and NorthEast Greenland: Blokelv-1 borehole, Jameson Land Basin. Geological Survey of Denmark and Greenland Bulletin 42, 15-37. https://doi. org/10.34194/geusb.v42.4308

Alsen, P. \& Surlyk, F. 2004: Maximum Middle Jurassic transgression: evidence from new ammonite finds, Bjørnedal, Traill $\varnothing$, East Greenland. In: Stemmerik, L. \& Stouge, S. (eds): The Jurassic of North-East Greenland. Geological Survey of Denmark and Greenland Bulletin 5, 31-49. https://doi.org/10.34194/geusb.v5.4806

Alsgaard, P.C., Felt, V.L., Vosgerau, H. \& Surlyk, F. 2003: The Jurassic of Kuhn $\varnothing$, North-East Greenland. In: Ineson, J.R. \& Surlyk, F. (eds): The Jurassic of Denmark and Greenland. Geological Survey of Denmark and Greenland Bulletin 1, 865-892. https://doi.org/10.34194/geusb. v1.4691

Beauvais, L. 1977: Une espèce nouvelle de madreporaire dans le Jurassique supérieur du Groenland et de l'Ecosse. Implications paléobiogéographiques. Géobios 10, 135-141. https://doi.org/10.1016/ s0016-6995(77)80062-4

Birkelund, T. \& Callomon, J.H. 1985: The Kimmeridgian ammonite faunas of Milne Land, central East Greenland. Bulletin Grønlands Geologiske Undersøgelse 153, 56 pp. https://doi.org/10.34194/bullggu.v153.6695

Birkelund, T. \& Perch-Nielsen, K. 1976: Late Palaeozoic - Mesozoic evolution of central East Greenland. In: Escher, A. \& Watt, W.S. (eds): Geology of Greenland, 304-339. Copenhagen: Geological Survey of Greenland.

Birkelund, T., Håkansson, E. \& Surlyk, F. 1971: New finds of Bathonian, Callovian, and Oxfordian ammonites in northern Jameson Land. Bulletin of the Geological Society of Denmark 20, 240-259.

Birkelund, T., Callomon, J.H. \& Fürsich, F.T. 1984: The stratigraphy of the Upper Jurassic and Lower Cretaceous sediments of Milne Land, central East Greenland. Bulletin Grønlands Geologiske Undersøgelse 147, 56 pp. https://doi.org/10.34194/bullggu.v147.6689

Bjerager, M., Alsen, P., Bojesen-Koefoed, J.A., Piasecki, S. \& Pilgaard, A. 2018a: Late Jurassic evolution of the Jameson Land Basin, East Greenland - implications of the Blokelv-1 borehole. In: Ineson, J. \& Bojesen-Koefoed, J.A. (eds): Petroleum geology of the Upper Jurassic - Lower Cretaceous of East and North-East Greenland: Blokelv-1 borehole, Jameson Land Basin. Geological Survey of Denmark and Greenland Bulletin 42, 149-168. https://doi.org/10.34194/geusb. v42.4325

Bjerager, M., Kjøller, C., Olivarius, M., Olsen, D. \& Schovsbo, N. 2018b: Sedimentology, geochemistry and reservoir properties of Upper Jurassic deep marine sediments (Hareelv Formation) in the Blokelv-1 borehole, Jameson Land Basin, East Greenland. In: Ineson, J. \& Bojesen-Koefoed, J.A. (eds): Petroleum geology of the Upper Jurassic - Lower Cretaceous of East and North-East Greenland: Blokelv-1 borehole, Jameson Land Basin. Geological Survey of Denmark and Greenland Bulletin 42, 39-64. https://doi.org/10.34194/geusb.v42.4309

Bjerager, M., Alsen, P., Bojesen-Koefoed, J., Fyhn, M.B.W., Hovikoski, J., Ineson, J.R., Nøhr-Hansen, H., Nielsen, L.H., Piasecki, S. \& Vosgerau, H. 2020: Cretaceous lithostratigraphy of North-East Greenland. Bulletin of the Geological Society of Denmark 68, 37-93. https://doi. org/10.37570/bgsd-2020-68-04

Bojesen-Koefoed, J.A., Petersen, H.I., Surlyk, F. \& Vosgerau, H. 1997: Organic petrography and geochemistry of inertinite-rich mudstones, Jakobsstigen Formation, Upper Jurassic, northeast Greenland: Indications of forest fires and variations in relative sealevel. International Journal of Coal Geology 34, 345-370. https://doi. org/10.1016/s0166-5162(97)00030-x

Bojesen-Koefoed, J.A., Kalkreuth, W., Petersen, H.I. \& Piasecki, S. 2012: A remote coal deposit revisited: Middle Jurassic coals at Kulhøj, western Germania Land, northeast Greenland. International Journal of Coal Geology 98, 50-61. https://doi.org/10.1016/j.coal.2012.04.006

Bruhn, R. \& Surlyk, F. 2004: Sand-grade density flow evolution on a shelf-edge-slope-basin-floor complex in the Upper Jurassic Olympen Formation, East Greenland. Petroleum Geoscience 10, 81-92. https:// doi.org/10.1144/1354-079302-559

Callomon, J.H. 1993: The ammonite succession in the Middle Jurassic of East Greenland. Bulletin of the Geological Society of Denmark 40, 83-113.

Callomon, J.H. 1994: Jurassic ammonite biochronology of Greenland and the Arctic. Bulletin of the Geological Society of Denmark 41, 128-137.

Callomon, J.H. \& Birkelund, T. 1980: The Jurassic transgression and the mid-late Jurassic succession in Milne Land, East Greenland. Geological Magazine 117, 211-310. https://doi.org/10.1017/s0016756800030442

Callomon, J.H. \& Birkelund, T. 1982: The ammonite zones of the Boreal Volgian (Upper Jurassic) in East Greenland. In: Embry, A.F. \& Balkwill, H.R. (eds): Arctic Geology and Geophysics. Canadian Society of Petroleum Geologists Memoir 8, 349-369.

Callomon, J.H., Alsen, P. \& Surlyk, F. 2015: The ammonites of the Middle Jurassic Cranocephalites beds of East Greenland. Geological Survey of Denmark and Greenland Bulletin 34, 1-86. https://doi.org/10.34194/ geusb.v34.4488

Clemmensen, L.B. 1976: Tidally influenced deltaic sequences from the Kap Stewart Formation (Rhaetian-Liassic), Scoresby Land, East Greenland. Bulletin of the Geological Society of Denmark 25, 1-13.

Clemmensen, L.B. \& Surlyk, F. 1976: Upper Jurassic coal-bearing shoreline deposits, Hochstetter Forland, East Greenland. Sedimentary Geology 15, 193-211. https://doi.org/10.1016/0037-0738(76)90016-6

Clemmensen, L.B., Kent, D.V., Mau, M., Mateus, O. \& Milàn, J. 2020. Triassic lithostratigraphy of the Jameson Land basin (central East Greenland), with emphasis on the new Fleming Fjord Group. Bulletin of the Geological Society of Denmark 68, 95-132. https://doi. org./10.37570/bgsd-2020-68-05

Dam, G. 1990a: Taxonomy of trace fossils from the shallow marine Lower Jurassic Neill Klinter Formation, East Greenland. Bulletin of the Geological Society of Denmark 38, 119-144.

Dam, G. 1990b: Palaeoenvironmental significance of trace fossils from the shallow marine Lower Jurassic Neill Klinter Formation, East Greenland. Palaeogeography, Palaeoclimatology, Palaeoecology 79, 221-248. https://doi.org/10.1016/0031-0182(90)90019-4

Dam, G. 1991: A sedimentological analysis of the continental and shallow marine Upper Triassic to Lower Jurassic succession in Jameson Land, East Greenland, 243 pp. Unpublished PhD thesis, 6 parts, University of Copenhagen, Denmark.

Dam, G. \& Christiansen, F.G. 1990: Organic geochemistry and source potential of the lacustrine shales of the Upper Triassic - Lower Jurassic Kap Stewart Formation. Marine and Petroleum Geology 7, 428-443. https://doi.org/10.1016/0264-8172(90)90019-d

Dam, G. \& Surlyk, F. 1992: Forced regressions in a large wave- and storm-dominated anoxic lake, Rhaetian-Sinemurian Kap Stewart 
Formation, East Greenland. Geology 20, 749-752. https://doi.org/10.11 30/0091-7613(1992)020<3C0749:frialw>2.3.co;2

Dam, G. \& Surlyk, F. 1993: Cyclic sedimentation in a large wave- and storm-dominated anoxic lake; Kap Stewart Formation (RhaetianSinemurian), Jameson Land, East Greenland. In: Posamentier et al. (eds): Sequence stratigraphy and facies associations. International Association of Sedimentologists Special Publication 18, 419-448. https://doi.org/10.1002/9781444304015.ch21

Dam, G. \& Surlyk, F. 1995: Sequence stratigraphic correlation of Lower Jurassic shallow marine and paralic successions across the Greenland-Norway seaway. In: Steel R.J. et al. (eds): Sequence stratigraphy on the northwest European margin. Norwegian Petroleum Society (NPF) Special Publication 5, 483-509. https://doi.org/10.1016/ s0928-8937(06)80083-4

Dam, G. \& Surlyk, F. 1998: Stratigraphy of the Neill Klinter Group; a Lower - lower Middle Jurassic tidal embayment succession, Jameson Land, East Greenland. Geology of Greenland Survey Bulletin 175, 80 pp. https://doi.org/10.34194/ggub.v175.5026

Dam, G., Surlyk, F., Mathiesen, A. \& Christiansen, F.G. 1995: Exploration significance of lacustrine forced regressions of the RhaetianSinemurian Kap Stewart Formation, Jameson Land, East Greenland. In: Steel, R.J. et al. (eds): Sequence stratigraphy on the northwest European margin. Norwegian Petroleum Society (NPF) Special Publication 5, 511-527. https://doi.org/10.1016/s0928-8937(06)80084-6

Decou, A., Andrews, S.D., Alderton, D.H.M. \& Morton, A. 2017: Triassic to Early Jurassic climatic trends recorded in the Jameson Land Basin, East Greenland: clay mineralogy, petrography and heavy mineralogy. Basin Research 29, 658-673. https://doi.org/10.1111/bre.12194

Donovan, D.T. 1953: The Jurassic and Cretaceous stratigraphy and palaeontology of Traill $\varnothing$, East Greenland. Meddelelser om Grønland 149(5), 1-14

Donovan, D.T. 1957: The Jurassic and Cretaceous Systems in East Greenland. Meddelelser om Grønland 155(4), 214 pp.

Donovan, D.T. 1964: Stratigraphy and ammonite fauna of the Volgian and Berriasian rocks of East Greenland. Meddelelser om Grønland 154(4), $34 \mathrm{pp}$.

Doyle, P. 1991: Belemnites from the Lower Jurassic of East Greenland and their biostratigraphic significance. Bulletin of the Geological Society of Denmark 39, 123-141.

Engkilde, M. 1994: The Middle Jurassic Vardekløft Formation, East Greenland: Depositional environments and sequence stratigraphy of shallow marine sandstones deposited in a low-gradient epeiric seaway, 207 pp. Unpublished PhD thesis, University of Copenhagen, Denmark.

Engkilde, M. \& Surlyk, F. 1993: The Middle Jurassic Vardekløft Formation of East Greenland - analogue for reservoir units of the Norwegian shelf and the northern North Sea. In: Parker, J.R. (ed.): Petroleum Geology of Northwest Europe: proceedings of the 4th Conference, 533-542. London: Geological Society. https://doi.org/10.1144/0040533

Engkilde, M. \& Surlyk, F. 2003: Shallow marine syn-rift sedimentation: Middle Jurassic Pelion Formation, Jameson Land, East Greenland. In: Ineson, J.R. \& Surlyk, F. (eds): The Jurassic of Denmark and Greenland. Geological Survey of Denmark and Greenland Bulletin 1, 813-863. https://doi.org/10.34194/geusb.v1.4690

Eide, C.H., Howell, J.A., Buckley, S.J., Martinius, A.W., Oftedal, B.T. \& Henstra, G.A. 2016: Facies model for a coarse-grained, tide-influenced delta: Gule Horn Formation (Early Jurassic), Jameson Land, Greenland. Sedimentology 63, 1474-1506. https://doi.org/10.1111/sed.12270

Fürsich, F.T. 1982: Upper Jurassic bivalves from Milne Land, East Greenland. Bulletin Grønlands Geologiske Undersøgelse 144, 126 pp. https://doi.org/10.34194/bullggu.v144.6686

Fürsich, F.T. \& Heinberg, C. 1983: Sedimentology, biostratinomy, and palaeoecology of an Upper Jurassic offshore sand bar complex. Bulletin of the Geological Society of Denmark 32, 67-95.

Ghisler, M. 1990: Geographical subdivision of Greenland. Rapport Grønlands Geologiske Undersøgelse 148, 8-10. https://doi.org/10.34194/rapggu.v148.8108

Guarnieri, P., Brethes, A. \& Rasmussen, T.M. 2017: Geometry and kinematics of the Triassic rift basin in Jameson Land (East Greenland). Tectonics 36, 1-13. https://doi.org/10.1002/2016tc004419
Håkansson, E., Birkelund, T., Heinberg, C. \& Willumsen, P. 1971: Preliminary results of mapping the Upper Jurassic and Lower Cretaceous sediments of Milne Land. Rapport Grønlands Geologiske Undersøgelse 37, 32-41. https://doi.org/10.34194/rapggu.v37.7273

Haller, J. 1971: Geology of the East Greenland Caledonides, 413 pp. New York: Interscience Publishers.

Hansen, B.B., Milàn, J., Clemmensen, L.B., Adolfssen, J.S., Estrup, E.J., Klein, N., Mateus, O. \& Wings, O. 2016: Coprolites from the Late Triassic Kap Stewart Formation, Jameson Land, East Greenland: morphology, classification and prey inclusions. In: Kear, B.P., Lindgren, J., Hurum, J.H., Milàn, J. \& Vajda, V. (eds): Mesozoic Biotas of Scandinavia and its Arctic Territories. Geological Society Special Publication (London) 434, 49-69. https://doi.org/10.1144/sp434.12

Hansen, C.F. 1999: Sedimentology, sequence stratigraphy and geochemistry of the Sortehat Formation, Jameson Land, East Greenland, 151 pp. Unpublished thesis, University of Copenhagen, Denmark.

Harris, T. 1937: The fossil flora of Scoresby Sound East Greenland. 5. Stratigraphic relations of the plant beds. Meddelelser om Grønland 112(1), $114 \mathrm{pp}$.

Heinberg, C. \& Birkelund, T. 1984: Trace fossil assemblages and basin evolution of the Vardekløft Formation (Middle Jurassic, Central East Greenland). Journal of Paleontology 58, 362-397.

Henstra, G.A., Grundvåg, S.-A., Johannessen, E.P., Kristensen, T.B., Midtkandal, I., Nystuen, J.P., Rotevatn, A., Surlyk, F., Sæther, T. \& Windelstad, J. 2016: Depositional processes and stratigraphic architecture within a coarse-grained rift-margin turbidite system: The Wollaston Forland Group, east Greenland. Marine and Petroleum Geology 76, 187-209. https://doi.org/10.1016/j.marpetgeo.2016.05.018

Hesselbo, S.P., Robinson, S.A., Surlyk, F. \& Piasecki, S. 2002: Terrestrial and marine extinction at the Triassic-Jurassic boundary synchronized with major carbon-cycle perturbation: a link to initiation of massive volcanism? Geology 30(3), 251-254. https://doi. org/10.1130/0091-7613(2002)030<0251:tameat>2.0.co;2

Hovikoski, J., Uchman, A., Alsen, P. \& Ineson, J. 2018: Ichnological and sedimentological characteristics of submarine fan deposits in a half-graben, Lower Cretaceous Palnatokes Bjerg Formation, NE Greenland. Ichnos 26(1), 28-57. https://doi.org/10.1080/10420940.2017.1396981

Kelly, S.R.A., Whitham, A.G., Koraini, A.M. \& Price, S.P. 1998: Lithostratigraphy of the Cretaceous (Barremian-Santonian) Hold with Hope Group, NE Greenland. Journal of the Geological Society (London) 155, 993-1008. https://doi.org/10.1144/gsjgs.155.6.0993

Kelly, S.R.A., Gregory, F.J., Braham, W., Strogen, D.P. \& Whitham, A.G. 2015: Towards an integrated Jurassic biostratigraphy for eastern Greenland. Volumina Jurassica 13(1), 43-64.

Knaust, D. 2019: The enigmatic trace fossil Tisoa de Serres, 1840. Earth-Science Reviews 188, 123-147. https://doi.org/10.1016/j. earscirev.2018.11.001

Koch, L. 1929: Stratigraphy of Greenland. Meddelelser om Grønland 73(2), 205-320.

Kokfelt, T.F., Keulen, N.T., Weng, W.L. \& Pedersen, M. 2013: Geological map of Greenland, 1:500 000, April 2013. Copenhagen: Geological Survey of Denmark and Greenland.

Koppelhus, E.B. \& Dam, G. 2003: Palynostratigraphy and palaeoenvironment of the Rævekløft, Gule Horn and Ostreaelv Formations (LowerMiddle Jurassic), Neill Klinter Group, Jameson Land, East Greenland. In: Ineson, J.R. \& Surlyk, F. (eds): The Jurassic of Denmark and Greenland. Geological Survey of Denmark and Greenland Bulletin 1, 723-775. https://doi.org/10.34194/geusb.v1.4688

Koppelhus, E.B. \& Hansen, C.F. 2003: Palynostratigraphy and palaeoenvironment of the Middle Jurassic Sortehat Formation (Neill Klinter Group), Jameson Land, East Greenland. In: Ineson, J.R. \& Surlyk, F. (eds): The Jurassic of Denmark and Greenland. Geological Survey of Denmark and Greenland Bulletin 1, 777-811. https://doi.org/10.34194/ geusb.v1.4689

Krabbe, H. 1996: Biomarker distribution in the lacustrine shales of the Upper Triassic - Lower Jurassic Kap Stewart Formation, Jameson Land, East Greenland. Marine and Petroleum Geology 13, 741-754. https://doi.org/10.1016/0264-8172(96)00035-9

Krabbe, H., Christiansen, F.G., Dam, G., Piasecki, S. \& Stemmerik, L. 1994 Organic geochemistry of the Lower Jurassic Sortehat Formation, 
Jameson Land, East Greenland. Rapport Grønlands Geologiske Undersøgelse 164, 5-18. https://doi.org/10.34194/rapggu.v164.8266

Kürschner, W.M., Mander, L. \& McElwain, J.C. 2014: A gymnosperm affinity for Ricciisporites tuberculatus Lundblad: implications for vegetation and environmental reconstructions in the Late Triassic. Palaeobiodiversity and Palaeoenvironments 94, 295-305. https://doi. org/10.1007/s12549-014-0163-y

Larsen, H.C. \& Marcussen, C. 1992. Sill-intrusion, flood basalt emplacement and deep crustal structure of the Scoresby Sund region, East Greenland. In: Storey, B.C., Alabaster, T. \& Pankhurst, R.J. (eds): Magmatism and the causes of continental break-up. Geological Society Special Publication (London) 68, 365-386. https://doi. org/10.1144/gs/.sp.1992.068.01.23

Larsen, M. 1995: Facies architecture and sequence stratigraphy of basement-onlapping shallow marine sandstones of the Charcot Bugt Formation, Middle Jurassic, East Greenland, 199 pp. Unpublished PhD thesis, University of Copenhagen, Denmark.

Larsen, M. \& Surlyk, F. 2003: Shelf-edge delta and slope deposition in the Upper Callovian - Middle Oxfordian Olympen Formation, East Greenland. In: Ineson, J.R. \& Surlyk, F. (eds): The Jurassic of Denmark and Greenland. Geological Survey of Denmark and Greenland Bulletin 1, 931-948. https://doi.org/10.34194/geusb.v1.4695

Larsen, M., Piasecki, S. \& Surlyk, F. 2003: Stratigraphy and sedimentology of a basement-onlapping shallow marine sandstone succession, the Charcot Bugt Formation, Middle-Upper Jurassic, East Greenland. In: Ineson, J.R. \& Surlyk, F. (eds): The Jurassic of Denmark and Greenland. Geological Survey of Denmark and Greenland Bulletin 1, 893-930. https://doi.org/10.34194/geusb.v1.4693

Lindgreen, H. \& Surlyk, F. 2000: Upper Permian - Lower Cretaceous clay mineralogy of East Greenland: provenance, palaeoclimate and volcanicity. Clay Minerals 35, 791-806. https://doi. org/10.1180/000985500547241

Mander, L., Kürschner, W.M. \& McElwain, J.C. 2010: An explanation for conflicting records of Triassic-Jurassic plant diversity. PNAS 107(35): 15351-15356. https://doi.org/10.1073/pnas.1004207107

Mander, L., Kürschner, W.M. \& McElwain, J.C. 2013: Palynostratigraphy and vegetation history of the Triassic-Jurassic transition in East Greenland. Journal of the Geological Society (London) 170, 37-46. https://doi.org/10.1144/jgs2012-018

Maync, W. 1947: Stratigraphie der Jurabildungen Ostgrönlands zwischen Hochstetterbugten $\left(75^{\circ}\right)$ und dem Kejser Franz Joseph Fjord $\left(73^{\circ}\right)$. Meddelelser om Grønland 132(2), 223 pp.

Maync, W. 1949: The Cretaceous beds between Kuhn Island and Cape Franklin (Gauss Peninsula), northern East Greenland. Meddelelser om Grønland 133(3), 291 pp.

Mathiesen, A., Christiansen, F.G., Bidstrup, T., Marcussen, C., Dam, G., Piasecki, S. \& Stemmerik, L. 1995: Modelling of hydrocarbon generation in the Jameson Land Basin East Greenland. First Break 13, 329341. $h$ ttps://doi.org/10.3997/2214-4609.201411833

McElwain, J.C. \& Punyasena, S.W. 2007: Mass extinction events and the plant fossil record. Trends in Ecology and Evolution 22(10), 548-567. https://doi.org/10.1016/j.tree.2007.09.003

McElwain, J.C., Popa, M.E., Hesselbo, S.P., Haworth, M. \& Surlyk, F. 2007: Macroecological responses of terrestrial vegetation to climatic and atmospheric change across the Triassic/Jurassic boundary in East Greenland. Paleobiology 33(4), 547-573. https://doi. org/10.1666/06026.1

McElwain, J.C., Wagner, P.J. \& Hesselbo, S.P. 2009: Fossil plant relative abundances indicate sudden loss of Late Triassic biodiversity in East Greenland. Science 324, 1554-1556. https://doi.org/10.1126/ science. 1171706

Milàn, J., Clemmensen, L.B., Schulz Adolfssen, J., Estrup, E.J., Frobøse, N., Klein, N., Mateus, O. \& Wings, O. 2012: A preliminary report on coprolites from the Late Triassic part of the Kap Stewart Formation, Jameson Land, East Greenland. In: Hunt et al. (eds): Vertebrate Coprolites. New Mexico Museum of Natural History and Science Bulletin 57, 203-205.

Möller, C., Mutterlose, J. \& Alsen, P. 2015: Integrated stratigraphy of Lower Cretaceous sediments (Ryazanian-Barremian) North-East Greenland. Palaeogeography, Palaeoclimatology, Palaeoecology 437, 85-97. https://doi.org/10.1016/j.palaeo.2015.07.014
Nøhr-Hansen, H. 1993: Dinoflagellate cyst stratigraphy of the Barremian to Albian, Lower Cretaceous, North-East Greenland. Bulletin Grønlands Geologiske Undersøgelse 166, 171 pp. https://doi. org/10.34194/bullggu.v166.6722

Nøttvedt, A., Johannessen, E.P. \& Surlyk, F. 2008: The Mesozoic of Western Scandinavia and East Greenland. Episodes 31(1), 59-65. https://doi.org/10.18814/epiiugs/2008/v31i1/009

Pauly, S., Mutterlose, J. \& Alsen, P. 2012a: Lower Cretaceous (upper Ryazanian - Hauterivian) chronostratigraphy of high latitudes (NorthEast Greenland). Cretaceous Research 34, 308-326. https://doi. org/10.1016/j.cretres.2011.11.011

Pauly, S., Mutterlose, J. \& Alsen, P. 2012b: Early Cretaceous palaeoceanography of the Greenland-Norwegian Seaway evidenced by calcareous nannofossils. Marine Micropalaeontology 90, 72-85. https://doi. org/10.1016/j.marmicro.2012.04.004

Pauly, S., Mutterlose, J. \& Alsen, P. 2013: Depositional environments of Lower Cretaceous (Ryazanian-Barremian) sediments from Wollaston Forland and Kuhn $\varnothing$, North-East Greenland. Bulletin of the Geological Society of Denmark 61, 19-36.

Pedersen, K.R. \& Lund, J.J. 1980: Palynology of the plant-bearing Rhaetian to Hettangian Kap Stewart Formation, Scoresby Sund, East Greenland. Review of Palaeobotany and Palynology 31, 1-69. https:// doi.org/10.1016/0034-6667(80)90022-6

Petersen, H.I. \& Vosgerau, H. 1999: Composition and organic maturity of Middle Jurassic coals, North-East Greenland: evidence for liptinite-induced suppression of huminite reflectance. International Journal of Coal Geology 41, 257-274. https://doi.org/10.1016/ s0166-5162(99)00022-1

Petersen, H.I., Bojesen-Koefoed, J.A., Nytoft, H.P., Surlyk, F., Therkelsen, J. \& Vosgerau, H. 1998: Relative sea-level changes recorded by paralic liptinite-enriched coal facies cycles, Middle Jurassic Muslingebjerg Formation, Hochstetter Forland, Northeast Greenland. International Journal of Coal Geology 36, 1-30. https://doi.org/10.1016/ s0166-5162(97)00032-3

Petersen, H.I., Bojesen-Koefoed, J.A. \& Nytoft, H.P. 2002: Source rock evaluation of Middle Jurassic coals, northeast Greenland, by artificial maturation: aspects of petroleum generation from coal. American Association of Petroleum Geologists Bulletin 86(2), 233-256. https:// doi.org/10.1306/61eeda9e-173e-11d7-8645000102c1865d

Piasecki, S. 1979: Hauterivian dinoflagellate cysts from Milne Land. Bulletin of the Geological Society of Denmark 28, 31-37.

Piasecki, S. \& Stemmerik, L. 2004: Jurassic dinoflagellate cysts from Hochstetter Forland, North-East Greenland. In: Stemmerik, L. \& Stouge, S. (eds): The Jurassic of North-East Greenland. Geological Survey of Denmark and Greenland Bulletin 5, 89-97. https://doi. org/10.34194/geusb.v5.4809

Piasecki, S., Callomon, J.H. \& Stemmerik, L. 2004: Jurassic dinoflagellate cyst stratigraphy of Store Koldewey, North-East Greenland. In: Stemmerik, L. \& Stouge, S. (eds): The Jurassic of North-East Greenland. Geological Survey of Denmark and Greenland Bulletin 5, 99-112. https://doi.org/10.34194/geusb.v5.4810

Piasecki, S., Bojesen-Koefoed, J.A. \& Alsen, P. 2020: Notes on the geology of the Falkebjerg region, Wollaston Forland, North-East Greenland. Bulletin of the Geological Society of Denmark 68, 155-170. https://doi. org/10.37570/bgsd-2020-68-07

Popa, M. \& McElwain, J.C. 2009: Bipinnate Ptilozamites nilssonii from Jameson Land and new considerations on the genera Ptilozamites Nathorst 1878 and Ctenozamites Nathorst 1886. Review of Paleobotany and Palynology 153, 386-393. https://doi.org/10.1016/j. revpalbo.2008.10.007

Pott, C. 2014: A revision of Wielandiella angustifolia, a shrub-sized bennettite from the Rhaetian-Hettangian of Scania, Sweden, and Jameson Land, Greenland. International Journal of Plant Sciences 175(4), 467499. https://doi.org/10.1086/675577

Poulsen, N.E. 1985: Dinocyststratigrafien i den nedre del af Hareelv Formationen ( Øvre Jura), Jameson Land, Østgrønland. Dansk Geologisk Forening, Årsskrift for 1984, 133-137.

Price, S.P. \& Whitham, A.G. 1997: Exhumed hydrocarbon traps in East Greenland: analogs for the Lower-Middle Jurassic play 
of Northwest Europe. AAPG Bulletin 81, 196-221. https://doi. org/10.1306/522b42e9-1727-11d7-8645000102c1865d

Ravn, J.P. 1911: On Jurassic and Cretaceous fossils from North-East Greenland. Meddelelser om Grønland 45(10), 437-500. https://doi. org/10.5962/bhl.title.29066

Rosenkrantz, A. 1929: Preliminary account of the geology of the Scoresby Sund district. Meddelelser om Grønland 73(2), 135-154.

Rosenkrantz, A. 1934: The Lower Jurassic rocks of East Greenland. Part I. Meddelelser om Grønland 110(1), 150 pp.

Rosenkrantz, A. 1942: The Lower Jurassic rocks of East Greenland. Part II. The Mesozoic sediments of the Kap Hope area, southern Liverpool Land area. Meddelelser om Grønland 110(2), 56 pp.

Seidler, L., Steel, R.J., Stemmerik, L. \& Surlyk, F. 2004: North Atlantic marine rifting in the Early Triassic - new evidence from East Greenland. Journal of the Geological Society (London) 161, 583-592. https://doi.org/10.1144/0016-764903-063

Spath, L.F. 1932: The invertebrate faunas of the Bathonian-Callovian deposits of Jameson Land (East Greenland). Meddelelser om Grønland 87(7), 158 pp.

Spath, L.F. 1935: The Upper Jurassic invertebrate faunas of Cape Leslie, Milne Land. I. Oxfordian and Lower Kimmeridgian. Meddelelser om Grønland 99(2), 82 pp.

Spath, L.F. 1936: The Upper Jurassic invertebrate faunas of Cape Leslie, Milne Land. II. Upper Kimmeridgian and Portlandian. Meddelelser om Grønland 99(3), 180 pp.

Spath, L.F. 1947: Additional observations on the invertebrates (chiefly ammonites) of the Jurassic and Cretaceous of East Greenland. I. The Hectoroceras fauna of S.W. Jameson Land. Meddelelser om Grønland 13(3), $70 \mathrm{pp}$.

Steinthorsdottir, M., Woodward, F.I., Surlyk, F. \& McElwain, J.C. 2012: Deep-time evidence of a link between elevated $\mathrm{CO}_{2}$ concentrations and perturbations in the hydrological cycle via drop in plant transpiration. Geology 40, 815-818. https://doi.org/10.1130/g33334.1

Steinthorsdottir, M., Tosollini, A.-M. \& McElwain, J.C. 2015: Evidence for insect and annelid activity across the Triassic-Jurassic transition of East Greenland. Palaios 30, 597-607. https://doi.org/10.2110/ palo.2014.093

Stemmerik, L. \& Piasecki, S. 1990: Post-Caledonian sediments in NorthEast Greenland between $76^{\circ}$ and $78^{\circ} 30^{\prime} \mathrm{N}$. Rapport Grønlands Geologiske Undersøgelse 148, 123-126. https://doi.org/10.34194/rapggu.v148.8131

Stemmerik, L., Clausen, O.R., Korstgård, J., Larsen, M., Piasecki, S., Seidler, L., Surlyk, F. \& Therkelsen, J. 1997: Petroleum geological investigations in East Greenland: project 'Resources of the sedimentary basins of North and East Greenland'. Geology of Greenland Survey Bulletin 176, 29-38. https://doi.org/10.34194/ggub.v176.5058

Surlyk, F. 1973: The Jurassic-Cretaceous boundary in Jameson Land, East Greenland. In: Casey, R. \& Rawson, P.F. (eds): The Boreal Lower Cretaceous. Geological Journal Special Issue 5, 81-100.

Surlyk, F. 1975: Block faulting and associated marine sedimentation at the Jurassic-Cretaceous boundary, East Greenland. NPF-Jurassic Northern North Sea Symposium 7, 1-31.

Surlyk, F. 1977a: Stratigraphy, tectonics and palaeogeography of the Jurassic sediments of the areas north of Kong Oscars Fjord, East Greenland. Bulletin Grønlands Geologiske Undersøgelse 123, 56 pp. https://doi.org/10.34194/bullggu.v123.6665

Surlyk, F. 1977b: Mesozoic faulting in East Greenland. In: Frost, R.T.C. \& Dikkers, A.J. (eds): Fault tectonics in NW Europe. Geologie en Mijnbouw 56, 311-327.

Surlyk, F. 1978a: Submarine fan sedimentation along fault scarps on tilted fault blocks (Jurassic-Cretaceous boundary, East Greenland). Bulletin Grønlands Geologiske Undersøgelse 128, 108 pp. https://doi. org/10.34194/bullggu.v128.6670

Surlyk, F. 1978b: Jurassic basin evolution of East Greenland. Nature 274(5667), 130-133. https://doi.org/10.1038/274130a0

Surlyk, F. 1978c: Mesozoic geology and palaeogeography of Hochstetter Forland, East Greenland. Bulletin of the Geological Society of Denmark 27, 73-87

Surlyk, F. 1984: Fan-delta to submarine fan conglomerates of the VolgianValanginian Wollaston Forland Group, East Greenland. In: Koster,
E.H. \& Steel, R.J. (eds): Sedimentology of gravel and conglomerates. Canadian Society of Petroleum Geologists Memoir 10, 359-382.

Surlyk, F. 1987: Slope and deep shelf gully sandstones, Upper Jurassic, East Greenland. AAPG Geologists Bulletin 71, 464-475. https://doi. org/10.1306/94886ecf-1704-11d7-8645000102c1865d

Surlyk, F. 1989: Mid-Mesozoic syn-rift turbidite systems: controls and predictions. In: Collinson, J.D. (ed.): Correlation in hydrocarbon exploration, 231-241. London: Graham \& Trotman for the Norwegian Petroleum Society (NPF)

Surlyk, F. 1990a: Timing, style and sedimentary evolution of Late Palaeozoic - Mesozoic extensional basins of East Greenland. In Hardman, R.F.P. \& Brooks, J. (eds): Tectonic events responsible for Britain's oil and gas reserves. Geological Society Special Publication (London) 55, 107-125. https://doi.org/10.1144/gsl.sp.1990.055.01.05

Surlyk, F. 1990b: A Jurassic sea-level curve for East Greenland. Palaeogeography, Palaeoclimatology, Palaeoecology 78, 71-85. https://doi.org/10.1016/0031-0182(90)90205-/

Surlyk, F. 1991: Sequence stratigraphy of the Jurassic - lowermost Cretaceous of East Greenland. AAPG Bulletin 75, 1468-1488. https:// doi.org/10.1306/0c9b296b-1710-11d7-8645000102c1865d

Surlyk, F. 2003: The Jurassic of East Greenland: a sedimentary record of thermal subsidence, onset and culmination of rifting. In: Ineson, J.R \& Surlyk, F. (eds): The Jurassic of Denmark and Greenland. Geological Survey of Denmark and Greenland Bulletin 1, 659-722. https://doi. org/10.34194/geusb.v1.4674

Surlyk, F. \& Clemmensen, L.B. 1975: A Valanginian turbidite sequence and its palaeogeographical setting (Kuhn $\varnothing$, East Greenland). Bulletin of the Geological Society of Denmark 24, 61-73.

Surlyk, F. \& Clemmensen, L.B. 1983: Rift propagation and eustacy as controlling factors during Jurassic inshore and shelf sedimentation in northern East Greenland. Sedimentary Geology 34, 119-143. https:// doi.org/10.1016/0037-0738(83)90083-0

Surlyk, F. \& Korstgård, J. 2013: Crestal unconformities on an exposed Jurassic tilted fault block, Wollaston Forland, East Greenland as an analogue for buried hydrocarbon traps. Journal of Marine and Petroleum Geology 44, 82-95. https://doi.org/10.1016/j.marpetgeo.2013.03.009

Surlyk, F. \& Noe-Nygaard, N. 1991: Sand bank and dune facies architecture of a wide intracratonic seaway: Late Jurassic - Early Cretaceous Raukelv Formation, Jameson Land, East Greenland. In: Miall, A.D. \& Tyler, N. (eds): The three-dimensional facies architecture of terrigenous clastic sediments and its implication for hydrocarbon discovery and recovery. SEPM (Society for Sedimentary Geology). Concepts in Sedimentology and Paleontology 3, 261-276. https://doi.org/10.2110/ csp.91.03.0261

Surlyk, F. \& Noe-Nygaard, N. 1995: High-angle clinoform beds - a recurrent architectural element in Jurassic shallow marine deposits of East Greenland. Sedimentary responses to forced regression: recognition, interpretation and reservoir potential. Geological Society, London, 7-9 September 1995. Programme with abstracts, 64-65.

Surlyk, F. \& Noe-Nygaard, N. 2000: Jurassic sequence stratigraphy of East Greenland. In: Hall, R.L. \& Smith, P.L. (eds): Advances in Jurassic research 2000. Proceedings of the 5th International Symposium on the Jurassic System. GeoResearch Forum 6, 357-366.

Surlyk, F. \& Noe-Nygaard, N. 2001a: Cretaceous faulting and associated coarse-grained marine gravity flow sedimentation, Traill $\varnothing$, East Greenland. In: Martinsen, O.J. \& Dreyer, T. (eds): Sedimentary environments offshore Norway - Palaeozoic to Recent. Norwegian Petroleum Society (NPF) Special Publication 10, 293-319. https://doi.org/10.1016/ s0928-8937(01)80019-9

Surlyk, F. \& Noe-Nygaard, N. 2001b: Sand remobilisation and intrusion in the Upper Jurassic Hareelv Formation of East Greenland. Bulletin of the Geological Society of Denmark 48, 211-230.

Surlyk, F. \& Noe-Nygaard, N. 2003: A giant sand injection complex: the Upper Jurassic Hareelv Formation of East Greenland. Geologia Croatica 56, 69-81.

Surlyk, F. \& Noe-Nygaard, N. 2005: A forced regressive shelf-margin wedge formed by transition-slope progradation: lowermost Cretaceous Rauk Plateau Member, Jameson Land, East Greenland. Bulletin of the Geological Society of Denmark 52, 227-243. 
Surlyk, F., Bromley, R.G., Asgaard, U. \& Pedersen, K.R. 1971: Preliminary account of the mapping of the Mesozoic formations of south-east Jameson Land. Rapport Grønlands Geologiske Undersøgelse 37, 24-32. https://doi.org/10.34194/rapggu.v37.7272

Surlyk, F., Callomon, J.H., Bromley, R.G. \& Birkelund, T. 1973: Stratigraphy of the Lower Jurassic - Lower Cretaceous sediments of Jameson Land and Scoresby Land, East Greenland. Bulletin Grønlands Geologiske Undersøgelse 105, 76 pp. https://doi.org/10.34194/bullggu.v105.6646

Surlyk, F., Noe-Nygaard, N. \& Dam, G. 1993: High and low resolution sequence stratigraphy in lithological prediction - examples from the Mesozoic around the northern North Atlantic. In: Parker, J.R. (ed.): Petroleum Geology of Northwest Europe. Proceedings of the 4th Conference, 199-214. London: Geological Society. https://doi. org/10.1144/0040199

Surlyk, F., Gjelberg, J. \& Noe-Nygaard, N. 2007: The Upper Jurassic Hareelv Formation of East Greenland: A giant sedimentary injection complex. In: Hurst, A. \& Cartwright, J. (eds): Sand injectites: implications for hydrocarbon exploration and production. AAPG Memoir 87, 141-149. https://doi.org/10.1306/1209858m871101

Sykes, R.M. 1974a: Sedimentological studies in southern Jameson Land, East Greenland. I. Fluviatile sequences in the Kap Stewart Formation (Rhaetic-Hettangian). Bulletin of the Geological Society of Denmark 23, 203-212.

Sykes, R.M. 1974b: Sedimentological studies in southern Jameson Land, East Greenland. II. Offshore-estuarine regressive sequences in the Neill Klinter Formation (Pliensbachian-Toarcian). Bulletin of the Geological Society of Denmark 23, 213-224.

Sykes, R.M. \& Brand, R.P. 1976: Fan-delta sedimentation: An example from the Late Jurassic - Early Cretaceous of Milne Land, central East Greenland. Geologie en Mijnbouw 55, 195-203.

Sykes, R.M. \& Surlyk, F. 1976: A revised ammonite zonation of the Boreal Oxfordian and its application in northeast Greenland. Lethaia 9, 421436. https://doi.org/10.1111/j.1502-3931.1976.tb00984.x

Therkelsen, J. \& Surlyk, F. 2004: The fluviatile Bristol Elv Formation, a new lithostratigraphical unit from Traill $\varnothing$, North-East Greenland. In: Stemmerik, L. \& Stouge, S. (eds): The Jurassic of North-East Greenland. Geological Survey of Denmark and Greenland Bulletin 5, 19-29. https://doi.org/10.34194/geusb.v5.4801
Underhill, J. \& Partington, M.A. 1993: Use of genetic sequence stratigraphy in defining and determining a regional tectonic control on the 'Mid-Cimmerian Unconformity' - implications for North Sea Basin development and the global sea-level chart. In: Weimer, P. \& Posamentier, H. (eds): Siliciclastic sequence stratigraphy. AAPG Memoir 58, 449-484.

Vischer, A. 1943: Die Postdevonische Tektonik von Ostgrönland zwischen $74^{\circ}$ und $75^{\circ} \mathrm{n}$. Br. Meddelelser om Grønland 133(1), 195 pp.

Vosgerau, H. 1997: Depositional environments and sequence stratigraphy of a Middle-Upper Jurassic early syn-rift succession deposited in a low-gradient epeiric seaway, the Wollaston Forland Basin, Northeast Greenland, 110 pp. Unpublished PhD thesis, 3 parts, University of Copenhagen, Denmark.

Vosgerau, H., Bojesen-Koefoed, J.A., Petersen, H.I. \& Surlyk, F. 2000: Forest fires, climate, and sea-level changes in a coastal plain-shallow marine succession (Early-Middle Oxfordian Jakobsstigen Formation, Northeast Greenland). Journal of Sedimentary Research 70, 408-418. https://doi.org/10.1306/2dc40919-0e47-11d7-8643000102c1865d

Vosgerau, H., Larsen, M., Piasecki, S. \& Therkelsen, J. 2004a: A new Middle-Upper Jurassic succession on Hold with Hope, North-East Greenland. In: Stemmerik, L. \& Stouge, S. (eds): The Jurassic of North-East Greenland. Geological Survey of Denmark and Greenland Bulletin 5, 51-71. https://doi.org/10.34194/geusb.v5.4807

Vosgerau, H., Alsen, P., Carr, I.D., Therkelsen, J., Stemmerik, L. \& Surlyk, F. 2004b: Jurassic syn-rift sedimentation on a seawards-tilted fault block, Traill $\varnothing$, North-East Greenland. In: Stemmerik, L. \& Stouge, S. (eds): The Jurassic of North-East Greenland. Geological Survey of Denmark and Greenland Bulletin 5, 9-18. https://doi.org/10.34194/ geusb.v5.4800

Williford, K.H., Grice, K., Holman, A. \& McElwain, J.C. 2014: An organic record of terrestrial ecosystem collapse and recovery at the TriassicJurassic boundary in East Greenland. Geochimica et Cosmochimica Acta 127, 251-263. https://doi.org/10.1016/j.gca.2013.11.033 